\title{
WestVirginiaUniversity
}

THE RESEARCH REPOSITORY @ WVU

Graduate Theses, Dissertations, and Problem Reports

2008

\section{Weston State Hospital}

\author{
Kim Jacks \\ West Virginia University
}

Follow this and additional works at: https://researchrepository.wvu.edu/etd

\section{Recommended Citation}

Jacks, Kim, "Weston State Hospital" (2008). Graduate Theses, Dissertations, and Problem Reports. 857.

https://researchrepository.wvu.edu/etd/857

This Thesis is protected by copyright and/or related rights. It has been brought to you by the The Research Repository @ WVU with permission from the rights-holder(s). You are free to use this Thesis in any way that is permitted by the copyright and related rights legislation that applies to your use. For other uses you must obtain permission from the rights-holder(s) directly, unless additional rights are indicated by a Creative Commons license in the record and/ or on the work itself. This Thesis has been accepted for inclusion in WVU Graduate Theses, Dissertations, and Problem Reports collection by an authorized administrator of The Research Repository @ WVU. For more information, please contact researchrepository@mail.wvu.edu. 


\title{
Weston State Hospital
}

\author{
Kim Jacks \\ Thesis submitted to the \\ Eberly College of Arts and Sciences \\ at West Virginia University \\ in partial fulfillment of the requirements \\ for the degree of
}

\section{Master of Arts}

in

History

\author{
Committee: \\ Elizabeth Fones-Wolf, Ph.D., Chair \\ Ronald Lewis, Ph.D. \\ Kenneth Fones-Wolf, Ph.D. \\ Department of History
}
Morgantown, West Virginia
2008

Keywords: Weston State Hospital; mental institutions, history; West Virginia Hospital for the Insane; Trans-Allegheny Lunatic Asylum 


\section{ABSTRACT \\ Weston State Hospital}

Kim Jacks

Weston State Hospital was a major mental institution in Weston, West Virginia. This study traces the history of the hospital from its construction in the 1860 s to its closing in 1994. It was established as the Trans-Allegheny Lunatic Asylum, and then called the West Virginia Hospital for the Insane from 1863 to 1915. The building was designed following the Kirkbride plan, which would allow for a pleasant and orderly place of refuge for 250 patients. Gradual overcrowding led to its becoming a custodial facility for over 2300 patients by the 1950s. This study examines the management of the institution, the daily life of both patients and employees, and the methods of treatment offered, from gentle "moral treatment" to hydrotherapy, electric shock, lobotomy, and psychotropic medications. The effects of deinstitutionalization are discussed, including the numbers of mentally ill now among the homeless or held in jails and prisons. 


\section{Contents}

Introduction: "A well-ordered institution" 1

Chapter one: $1858-1900$

The Trans-Allegheny Lunatic Asylum and "moral treatment" 8

Constructing the "largest hand-cut stone building in North America" 13

Managing the West Virginia Hospital for the Insane 25

Chapter two: 1900-1950

Weston State Hospital and institutional life $\quad 38$

Deteriorating conditions and new treatments: Shock therapy, lobotomies, and antipsychotic medications 49

Chapter three: 1950-1994

1950s: Softball teams to shock treatments 65

1960s: The arrival of community care and the Alcohol Treatment Unit 75

1970s and 1980s: Drug treatment and increasing patients' rights 82

1990s: Improving quality of care and closing the hospital 94

Conclusion: De-institutionalization: Into the community, the streets, the jails... 105

Appendix: Voices from Weston 114

Bibliography $\quad 160$ 


\section{Introduction "A well-ordered institution"}

Weston State Hospital, originally known as the Trans-Allegheny Lunatic Asylum, now stands silent along the banks of the West Fork of the Monongahela River in central West Virginia. This massive stone edifice, constructed in the mid-nineteenth century, was established to provide care and cure for its 250 patients in this peaceful, pastoral setting. Over the decades, it transformed into a custodial holding facility for over 2300 patients. The gradual release of its patients in recent years has led to the closing of its doors, leaving behind a formerly grand but now deteriorating structure and the memories of the thousands who lived and worked here through its 130-year existence.

How did Weston State Hospital come to exist? Why did state governments choose to build such monolithic institutions as a way to care for the mentally disturbed? From colonial times through the 1830s, the mentally ill in America were usually cared for by their families. In many small towns, it was not unusual to have a "village idiot" who wandered through the community and received handouts. As long as communities remained very small, an insane person or two roaming about the town was not seen as a problem. Unless they became violent, they were tolerated. If they became too difficult for their families, they might be jailed or sent to an almshouse. In larger communities, hospitals of some sort might be set up, but offered only custodial care. There were few institutions for the insane in the United States before the 1840s. ${ }^{1}$ As community populations increased, the mentally disturbed were increasingly held in confinement in jails or poorhouses, and their situation deteriorated.

The first attempts to actually cure the mentally ill began in France and Great Britain with the rise of Enlightenment thought of the eighteenth century, inspired by a confidence in science and progress. These new theories on treating mental illness, which spread to the 
United States in the early nineteenth century, asserted that mental illness could be cured by removing the afflicted person from the environment that drove him mad and by providing him peace and quiet. Thus early institutions were called "retreats" or "asylums," places of refuge and sanctuary. ${ }^{2}$ Also by the 1830s, many reformers who studied insanity and crime had become concerned about the stability of American society. Too many changes were occurring, particularly the increase in population and immigration. The causes of crime, poverty, and insanity were beginning to be seen as a result of faults in the community. ${ }^{3}$ Although doctors might sometimes attribute mental illness to a physical injury, such as a blow to the head, they usually felt that there was something in the unsettled society that produced the mental disturbance. Some suspected that mental illnesses were caused by instability in the social order in America. Too many people were trying to reach out of their present class, pursuing career or monetary ambitions beyond what their fathers had attained. Excessive studying and religious excitement were also seen as strains on one's mental health and were considered a cause of insanity. Reformers believed that communities needed more discipline and order, and that people should remain content with their place in society. ${ }^{4}$

Weston State Hospital in the 1930s.

West Virginia and Regional History Collection West Virginia University Libraries

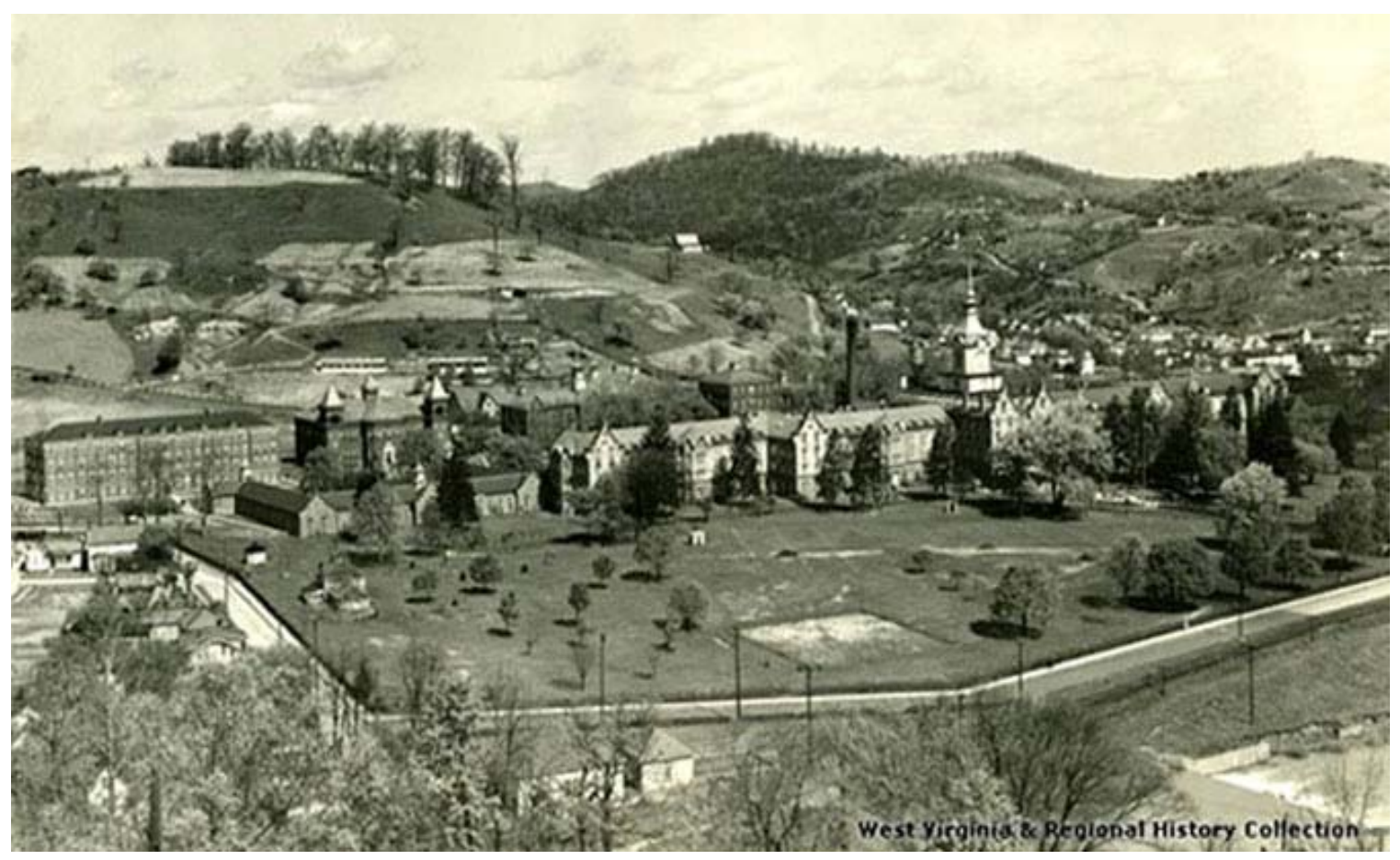


Some who have studied mental institutions, however, such as George Dowdall, have challenged the idea that mental institutions were established as a form of social control. Dowdall said that by examining statistics from the late nineteenth century on causes of hospitalization and lengths of stay, he could see no relationship between length of stay and class, sex, or ethnicity. He argued that institutions were not primarily a form of social control over women, immigrants, or the lower classes as some historians have put forth. ${ }^{5}$ Dowdall found that the number of physicians in a state, which also correlates with the population growth, seemed to correspond with the founding of state mental hospitals. He saw the professionalization of medicine as leading to the establishment of hospitals. The creation of the Association of Medical Superintendents of American Institutions for the Insane (AMSAII, later called the American Psychiatric Association) in 1844 was "a crucial step forward in the movement to build asylums...... The AMSAII rapidly became the virtually unchallenged source of expertise available to guide each state's decision about when and how to operate an institution."'6

David Rothman, in Discovery of the Asylum, maintained that reformers began to work for the establishment of asylums to provide stability in the lives of the mentally disturbed. Each asylum would be a "well-ordered institution," as proponents often phrased it, a place of discipline and calm routine. ${ }^{7}$ Dr. Thomas Kirkbride was instrumental in designing many mental institutions in the United States, including the Trans-Allegheny Lunatic Asylum in Weston. ${ }^{8}$ Dr. Kirkbride served as the superintendent of the Pennsylvania Hospital for the Insane from 1840 to 1883, and was extremely influential in not only the physical design of institutions, but in establishing a plan for proper care of the mentally ill. ${ }^{9} \mathrm{He}$ believed that the mentally ill could be cured if treated promptly and removed from the place where the distress was occurring, which was usually at home with family. He also acknowledged that just as a person with a physical illness might be cured and then later have a recurrence of the disease, a mentally ill person might be cured and then become ill again due to some stress or sadness, but this ought not be a reason to say they were not cured. Kirkbride said that mental illness was not like having a case of the measles, to which one became immune after surviving it. ${ }^{10}$

Directors of early asylums insisted that mental illness was curable, and they announced dramatic results. Samuel Woodward, superintendent of the Worcester Asylum in Massachusetts, claimed in 1834 that eighty-two percent of the recent patients in his institution recovered. John Galt in Virginia and William Awl in Ohio declared in 1842 that, excluding 
patients who had died, they had one hundred percent recoveries. The statistics were misleading, as "recovery" was defined as release from the asylum. A single patient might be admitted and released repeatedly, and counted as cured each time, improving the rates of success. These statistical claims were not questioned until the 1870s. Throughout the 1860s, the remarkable cures continued to be reported, and there was intense competition between medical superintendents of various asylums to prove their successes with high rates of cure. ${ }^{11}$

One of the most influential advocates for the establishment of mental asylums in the United States in the nineteenth century was Dorothea Dix. She was born in 1802 in Hampden, Maine. For several decades, beginning in the 1840s, Dix worked for reform in the care of the indigent mentally ill. From 1843 to 1845 Dix investigated eighteen state prisons, three hundred county jails, and over five hundred almshouses throughout the United States. She was appalled at the terrible conditions she discovered. She wrote about her findings and made presentations to state legislators to lobby for new hospitals or improvements to existing ones. Dix was instrumental in the establishment of major mental hospitals in many states. ${ }^{12}$ She vividly described how the mentally ill were confined with criminals in jail cells, often without heat or proper clothing. In jails and even in private houses, they were often confined to pens or cages. Dix wrote about a mentally ill man she had observed in Illinois in a memorial presented to the Illinois state legislature:

It was an intensely hot day last summer, when I visited Fanning. He was confined in a roofed pen, which enclosed an area of about eight feet by eight — probably a few inches over. The interstices between the unhewn logs freely admitted the scorching rays of the sun then; as they now afford admission to the frequent rains, the driving snow, and the pinching frost. He was without bed and without clothing; his food, of the coarsest kind, was passed through a space between the logs; "no better," said a neighbor, "than the hogs are fed."

Some sort of course bed-clothing and garments, at times were supplied, but usually not. His feet had been frozen, and had perished; upon the shapeless stumps, he could, aided by some motion of his shoulders, raise his body partially against the side of the pen. This wretched place was cleaned "once in a week or fortnight," in mild weather; not so in the wet, cold, wintry seasons. I was told that when the pen was opened for this purpose, the help of neighbors was requisite: "We have men called, and they go in and the tie him strongly with ropes, and get him out on the ground, and then they clean the place, and him, by throwing over pails of water." Of 
course no fire is here introduced in the cold winter weather; but a singular expedient has been adopted, as horrible as it is singular: beneath the pen is excavated a pit about six feet deep and six on either side. This drear, ghastly place is entered through a trap-door; neither light, heat, nor ventilation are there; but there is to be found a pining, desolate, suffering maniac, whose piteous groans, and frantic cries, would move to pity the hardest heart.

But one effective remedy for these woes is presented: it can only be found in a well established, skillfully conducted hospital. ${ }^{13}$

Dix set forth in her writing and speeches several arguments for the establishment of government-sponsored asylums for the mentally ill, beyond her graphic descriptions of abused and neglected people. She stated that governments had a moral obligation to care for certain people - the blind, the deaf, and the insane. Patients in asylums often recovered from their illnesses and were able to return to their communities, thus costing the state much less than continued confinement in prisons or almshouses, where they received no treatment. Rather than staying in the environment where the illness began, the insane person needed to be removed to an asylum where there were physicians trained in the treatment of the mentally ill who were more likely to help them improve. She noted that mentally ill persons often became enraged at those closest to them, whereas a stranger could calm and control the patient. Leaving an insane person in a household also was very disturbing to the general order of things and especially difficult for the children present. Some of the insane were dangerous to the community or to themselves and required

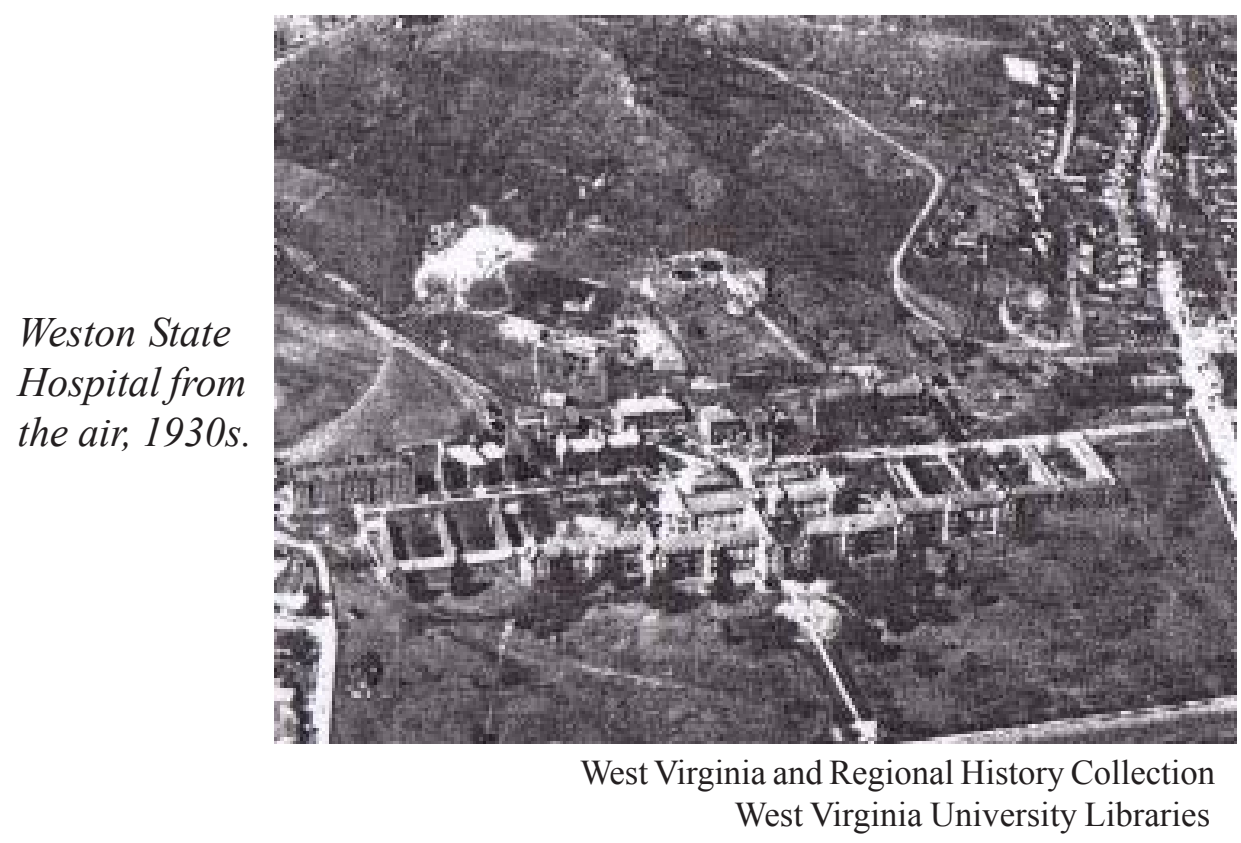


confinement and treatment. ${ }^{14}$ Dix also noted the good effects that labor had on the insane when in hospitals. Patients who worked at farming, gardening, carpentry, or shoemaking at an asylum often improved remarkably. She related the story of the insane inmates of the Boston almshouse who had been kept in filthy cages, where "they howled, and gibbered, and shrieked, day and night, like wild beasts raving in their dens. They knew neither decency or quiet." When moved to the Retreat at Hartford, they were cleaned up, kept in comfortable rooms, and gradually given employment in the gardens, kitchen, or sewing room. Their health and behavior greatly improved, and although only one-sixth of them were cured, they were able to be orderly and engage in some employment and be "capable of receiving pleasure" rather than living "in their former state of anguish."15

Historians interpret the decision to build these huge mental institutions in different ways. One view is that scientific advances were making it possible to develop some therapies to treat the mentally ill, and reformers such as Dix insisted that such treatment be available to the poor. A second perspective is that the elite of America used asylums and penitentiaries as a means of social control as they grew increasingly concerned over the rise in immigration, industrialization, and urbanization. ${ }^{16}$ Whatever the motivation, possibly a blend of these two perspectives plus the simple need for a place to house these unfortunate people, the construction of asylums for the mentally ill increased in the midnineteenth century, and the legislators of Virginia decided to add a new asylum to the western portion of their state.

Notes

${ }^{1}$ David L. Lightner, ed., Asylum, Prison, and Poorhouse: The Writings and Reform Work of Dorothea Dix in Illinois (Carbondale: Southern Illinois University Press, 1999), 9-10.

${ }^{2}$ Ibid., 9-11.

${ }^{3}$ David J. Rothman, The Discovery of the Asylum: Social Order and Disorder in the New Republic (Glenview, Illinois: Scott, Foresman and Company, 1971), xix.

${ }^{4}$ Ibid., 111-119, 127.

${ }^{5}$ George Dowdall, The Eclipse of the State Mental Hospital: Policy, Stigma, and Organization. Albany, NY: State University of New York Press, 1996, 101.

${ }^{6}$ Ibid., 40, 28. 
${ }^{7}$ Rothman, Discovery of the Asylum, 138.

${ }^{8}$ Joy Gilchrist-Stalnaker, A Short History of Weston Hospital (Weston, WV: Hacker's Creek Pioneer Descendants, 2001), 1.

${ }^{9}$ Rothman, Discovery of the Asylum, 134.

${ }^{10}$ Thomas S. Kirkbride, On the Construction, Organization and General Arrangements of

Hospitals for the Insane (Philadelphia: J.B. Lippincott, 1880; reprint, New York: Arno Press, 1973), 23-24.

${ }^{11}$ Rothman, Discovery of the Asylum, 131-132.

${ }^{12}$ Lightner, Asylum, Prison, and Poorhouse, 1-4.

${ }^{13}$ Ibid., 27-29.

${ }^{14}$ Ibid., 15-18.

${ }^{15}$ Ibid., 20-25.

${ }^{16}$ Ibid., 114. 


\section{Chapter one 1858-1900}

\section{The Trans-Allegheny Lunatic Asylum and "moral treatment"}

In 1858, the state government of Virginia voted to add a third mental institution in their state, due to overcrowding in the existing ones in Williamsburg and Staunton. This new asylum was to be established in the western portion of the state, west of the Alleghenies, in the area that was soon to become West Virginia with the division of the state in the Civil War. A commission was appointed to locate a site for this new institution by evaluating several towns, including Fayetteville in Fayette County, Sutton in Braxton County, and Weston in Lewis County. ${ }^{1}$

Several influential Weston citizens were in the government in Richmond at this time, including Senator John Brannon, Delegate William Arnold, and Jonathan M. Bennett, the First Auditor of Virginia. These men lobbied heavily for Weston, and sent word back to their hometown to spruce things up before the arrival of the selection committee. Houses in Weston were whitewashed and painted, fences mended, streets graveled, and sidewalks repaired. Rubbish was burned or hauled away, holes in the streets were filled, and "the whole town was made to present an outward appearance of snug prosperity and a high order of citizenship."2 When the commissioners arrived, they were greeted with a brass band, the Sons of Temperance, and children leading a parade to the proposed construction site. ${ }^{3}$ The commissioners were wined and dined and entertained for several days. They evaluated the proposed site along the West Fork of the Monongahela River, noting the water and coal supply and the ample amount of stone and lumber for building materials in the area. ${ }^{4}$ They decided unanimously that the institution should be located in Weston. ${ }^{5}$ One might wonder why a community would desire a lunatic asylum, but the potential economic gains from construction, employment, and provision of supplies for the hospital made it quite enticing. Communities certainly competed for the acquisition of such institutions. 
Other western Virginia towns, particularly the larger Wheeling, were miffed at the choice of Weston, and criticized the selection of such an insignificant village for the asylum site. Weston's population was approximately 700 in 1858. The local Weston newspaper, The Herald, defended the town by listing its local businesses in its October 11, 1858,

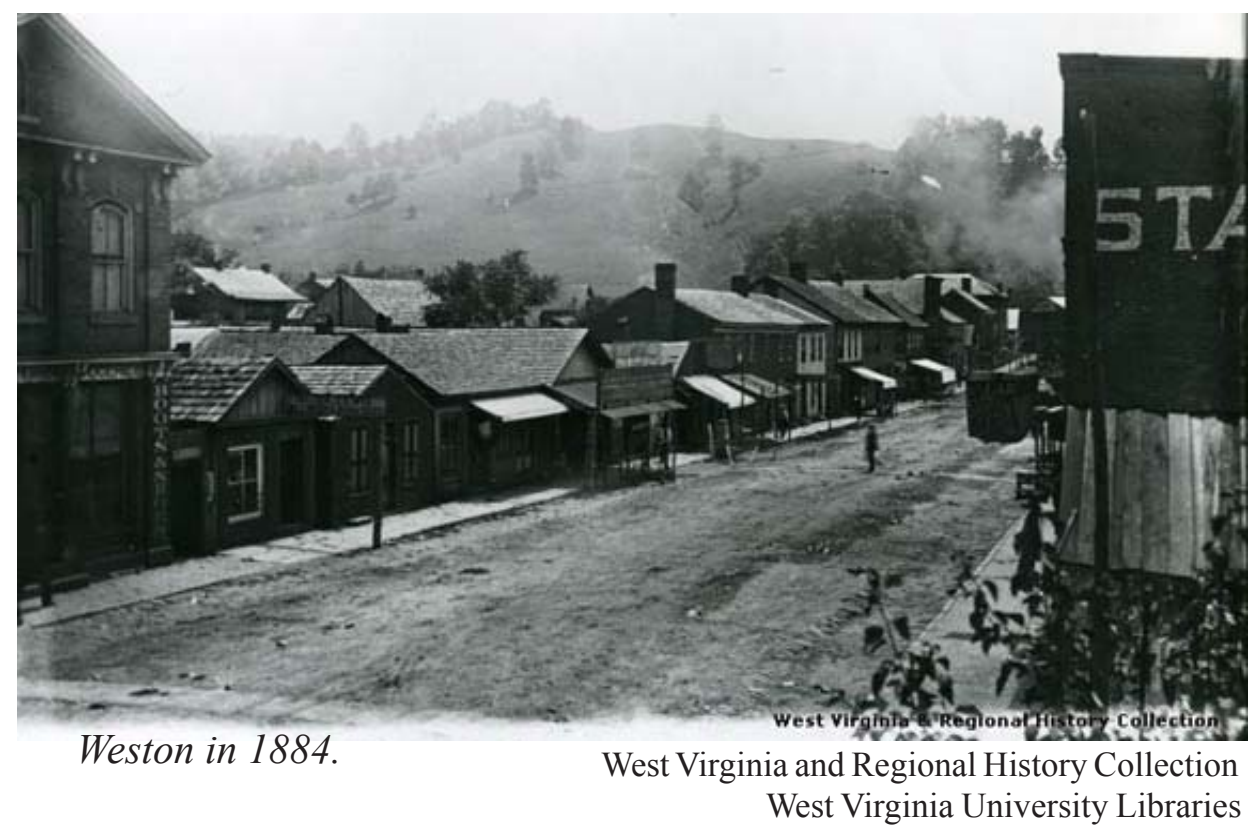

issue. The list included six retail merchants, one grocer, four blacksmiths, a silversmith, several carpenters and cabinetmakers, a tailor, a saddler, a tinner, and a tanner. Also mentioned were a hat and shoe store, an iron foundry, a wagon maker, a livery stable, two bricklayers, a plasterer, a painter, a stonecutter and a stonemason. The prospect of a huge construction project must have raised the spirits of all these businessmen, particularly those in the building trades. The article also noted that Weston had a "Flouring and Sawmill, four good Hotels, four Churches, a male Academy, a Branch of the Exchange Bank, a Lyceum, with a good library, four Physicians and a score of respectable Lawyers." Weston was the county seat of Lewis County, and it had a branch of the Exchange Bank of Virginia, established in 1852, which was the only bank between Staunton, Virginia, and Chillicothe, Ohio, east to west, and between Lewisburg and Wheeling, Virginia, north to south. ${ }^{7}$ It has sometimes been said that Weston was given a choice between having a mental asylum or a college, but this is untrue. There were no plans in the 1850 s for what became West Virginia University, which was later built in Morgantown. However, Weston was considered for the site of West Virginia Wesleyan College. Neighboring Buckhannon 
was chosen instead, with one of the reasons being that Weston had many saloons and Buckhannon had none. ${ }^{8}$

The choice of Weston as the location of the Trans-Allegheny Lunatic Asylum was one of the most important events in the history of Weston. There were several immediate effects on the town. New families moved in, hoping to obtain employment or in some other way gain in the increased commercial activity created by the hospital. The area around the construction site was divided into town lots. A store was built nearby and a boarding house was constructed to house laborers. The population of Weston continued to increase. There had been about 400 people in Weston in 1855, 820 in 1860 and 1000 in 1861. New stores were opened and existing ones expanded their business. The rest of Lewis County also experienced prosperity. Though there were three major grain mills in the area, the mill in Weston could not provide enough power by water to supply the needs of the populace and so had to install a steam engine.

The state authorities in Richmond began acquiring the land for the asylum site. Initially they purchased 269 acres for $\$ 9809$. A balance of $\$ 15,000$ was left to start the buildings. ${ }^{10}$ Two experts in the treatment of the insane were chosen as advisors for the project, Francis T. Striblin of eastern Virginia and Dr. Thomas Kirkbride, Superintendent of the Pennsylvania Hospital for the Insane. A plan for a facility to house 250 patients was drawn, with R. Snowden Andrews as architect. His proposal, based on the Kirkbride Plan, was projected to cost $\$ 395,000$. $^{11}$

Dr. Kirkbride, who was so influential in the plan of the hospital in Weston as well as many others, advocated a philosophy known as "moral treatment," which had originated with a French physician, Philippe Pinel, in the 1790s. Moral treatment was meant to improve the patient's morale by providing more humane treatment, comfortable living conditions, and a nurturing environment. Patients would be classified according to type of mental illness they had and be given appropriate therapeutic treatment. ${ }^{12}$ Moral management was becoming popular by the mid-nineteenth century, and saw mental illness as more of an emotional disorder than a problem with thought processes. Insanity was not necessarily a physical disease. The insane needed to be treated kindly. Fearful and harsh treatments only made patients worse, and use of restraints should be avoided — patients should be taught self-control through "gentle but firm persuasion."13

William Tuke and Quakers in York, England, had followed this philosophy in setting up a retreat for the mentally ill in 1796, where patients were treated with gentleness, pro- 
vided plenty of food, and kept busy with tasks such as gardening, sewing, and reading. ${ }^{14}$ The Quakers attempted to bring out the "inner light" in each patient—believing that each was capable of goodness in a positive environment. ${ }^{15}$ Transferred to America, this philosophy was followed from the 1840s to the 1880s at the Pennsylvania Hospital for the Insane under the supervision of Dr. Kirkbride, himself a Quaker. He was described as "humble, soft-spoken, simple in his dress, and reflective in his thoughts." ${ }^{16}$ Kirkbride's hospital near Philadelphia included a beautiful dining room, a game room, a bowling alley, a greenhouse, a museum, and a library. Attractive landscaping and flowerbeds graced the grounds. Patients were awakened at 6 A.M. and exercised, worked, read, or took classes in sewing or reading. Evening entertainments were provided, with lectures, concerts and other activities. Employees were chosen with care, as Kirkbride wanted only pleasant and gentle people who would not be "keepers" of the insane but "attendants" to the patients. Kirkbride was also an excellent doctor who counseled patients to take responsibility for their behavior, resist their mad thoughts or depression, and help themselves become well, as he assured them that they were not doomed to be ill forever. ${ }^{17}$

Kirkbride lectured and wrote about the proper construction and management of mental institutions. He felt that the maximum number to be housed in these asylums was

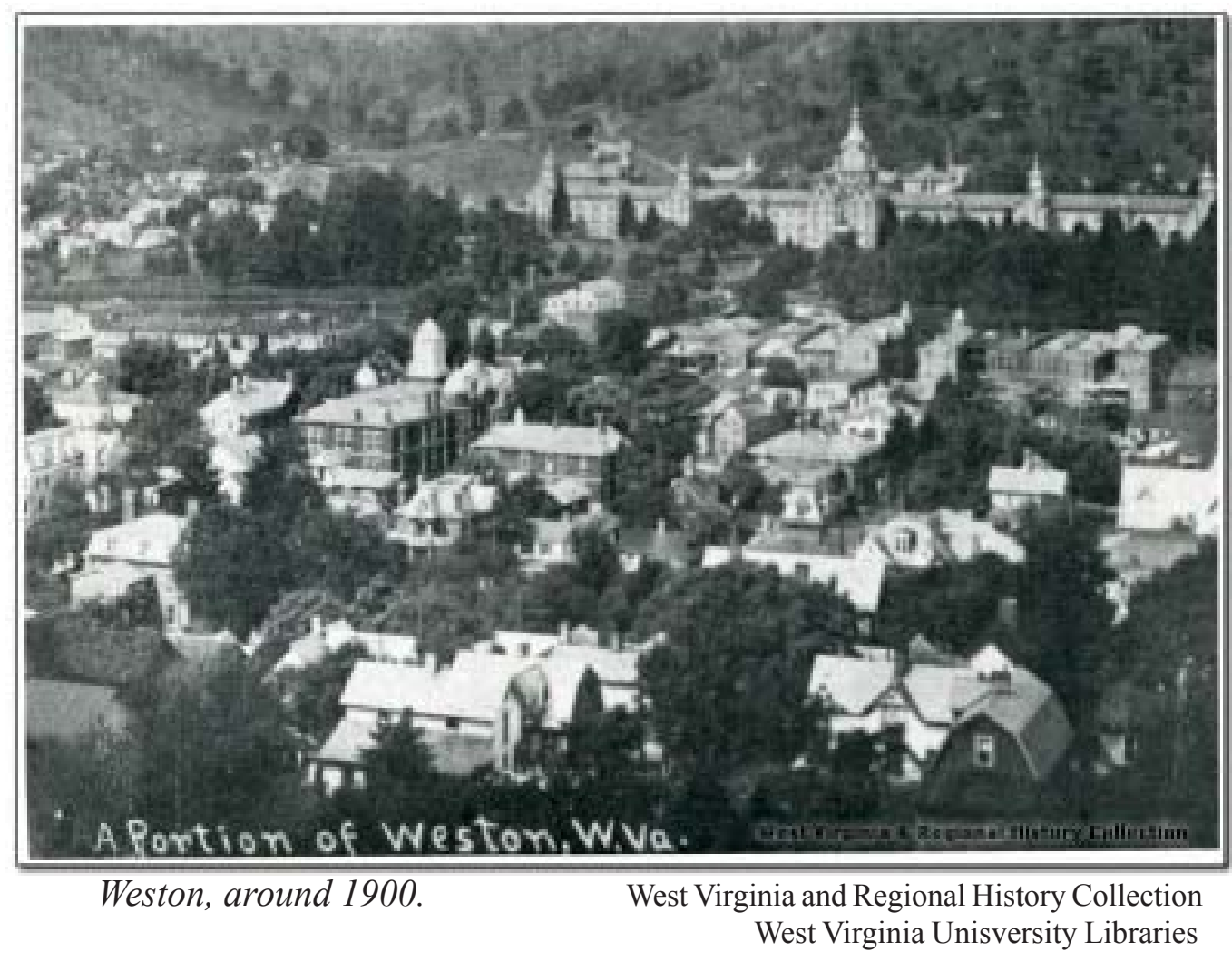


250 patients. The location should be rural, though it should be accessible to good roads and possibly railroads. The setting needed to be pastoral, pleasant, and private, but not far from a town of enough size to provide supplies. Practical considerations such as water supply and tillable soil were also important. At least one hundred acres should be provided for the site, with fifty acres around the building preserved as a "pleasure ground" for the patients, and these several acres should be kept in "groves or woodlands" as a place of pleasant shade for the patients. Walkways were beneficial, and separate park areas should be available to men and women. Plenty of land was needed for farming, gardening, and room for exercise and labor for the patients. The proposed site at Weston for the Trans-Allegheny Lunatic Asylum could meet these criteria. The site at Weston was rural, just across the small West Fork River from the town. Weston was at the crossroads of some major roads, but had no railway service yet. Kirkbride also wrote in detail of the practical needs of an institution. He knew that for 250 patients, at least 100,000 gallons of water should be stored in tanks to handle the laundry, toilets, cleaning, cooking, and water treatments for the ill, as well as to have an ample supply in case of fire. He estimated that 50,000 gallons a day were required for normal use. ${ }^{18}$ Kirkbride described the proper ways to install drainage, plastering, fire protection, and many other details..$^{19}$ He was quite knowledgeable, even though he was not an architect himself, and many hospitals throughout the United States were based on his plan, and are known as Kirkbride buildings.

The architectural design of the Weston hospital followed the typical pattern of Kirkbride institutions. A central structure, four stories high, would sit in the center, and from this would extend long, straight wings. The main section of a Kirkbride building usually had a tall cupola, as Weston's would with a central clock tower. The windows of the patients' rooms down the wings were to be regular and repetitive, almost factory-like. Rothman suggests in The Discovery of the Asylum that, as an alternative, they might have instead built many small houses for the same cost, housing eight or ten patients in each, and each house could have been cared for by a married couple, providing a more family like setting with easier grouping of similar patients. But designers of these institutions wanted to maintain an image of fixed order, with consistency and repetitiousness symbolizing the bringing of order into the lives of the insane. ${ }^{20}$ The wings were divided in sections, each set further back from the one adjoining it. This was to allow abundant light and air into each ward in order to promote improved health for the residents. 


\section{Constructing the "largest hand-cut stone building in North America"}

Thus with a site selected and an architectural plan set, work began on the asylum in Weston in the spring of 1859. The construction of this huge institution employed many workers for a number of years. Some of the first laborers brought in to clear the site were African American convicts sent by Governor Wise from Richmond in October of 1858. A few months later, in April of 1859, the local newspaper reported, under the headline, "Stampede of Negro Convicts," that eight of twenty-three convict workers at the asylum site had escaped from their quarters. They had accomplished this by convincing their guard that they "had urgent necessities outside the prison... and he, thoughtlessly, allowed them to go out, supposing they would return. But much to his surprise and chagrin, they failed to make their appearance." 21 The night was dark and rainy, and the men, not knowing the area, became separated and lost or otherwise they might have succeeded in their escape. All were recaptured within a few days. The escapees admitted that a white man had given them instructions on how to reach the Ohio River, their goal. The newspaper stated that they were thereafter to be "kept under a stricter watch." 22 The blockhouse for these men was one of the first structures built on the hospital grounds. A sawmill and a brick oven were also constructed, and the building materials were prepared on the site. ${ }^{23}$

Many workers, some hired and some convict labor, made bricks and quarried stone. An excellent quality of blue sandstone was used, which was easily tooled with a hammer and chisel. Initially the sandstone was quarried at Mt. Clare in neighboring Harrison County and at other quarries, and then hauled to the site by wagon. ${ }^{24}$ In 1870 , a new quarry was opened on the bank of the river just 600 feet in front of the hospital, and a tramway was built to transport the stone to the main building with a single mule hauling the blocks. Another quarry was opened on the hillside behind the main building, one-third of a mile away. ${ }^{25}$ The saw mill, brick ovens, planing mill, and lath mill were all set up to be run from the same power house. ${ }^{26}$ Immigrants from Germany and Ireland worked as skilled stonemasons to fit the giant blocks together to form the walls. Descendants of many of these workers remained in the area. ${ }^{27}$ John May, an immigrant from Germany, was hired as superintendent of masonry at $\$ 85$ a month. In May of 1861 there were ten stonecutters and twelve stonemasons employed, along with four bricklayers and eleven carpenters. There were thirteen carters and fifty-one laborers. Many of the names on the time sheet for that month have an Irish ring-McLaughlin, McDonald, Gillooly, Murphy, Mulligan, and Flanagan. ${ }^{28}$ 
In the spring of 1861, when one wing of the hospital was under construction, the outbreak of the Civil War slowed progress. Virginia seceded from the Union, but many of the citizens of the western portion of the state chose to remain loyal, hence the subsequent division into two states. The government of Virginia ordered that the construction work be stopped on the asylum and that the allotted money, $\$ 27,000$ thus far, which was held in a Weston bank, be returned to Richmond to help defend the state in the Civil War. ${ }^{29}$ This money, however, ended up playing an important part in helping establish the new government of West Virginia. Citizens west of the Alleghenies had joined to organize a government in Wheeling, counter to the one in Richmond, declaring themselves the legitimate government of Virginia and receiving recognition from the federal government. ${ }^{30}$ A young Unionist Weston merchant, Presley Hale, was in Wheeling as a representative from Lewis County to this new government. He urged the new governor, Francis Pierpont, to retrieve this money in the bank in Weston before the Confederates gained control of it. Pierpont sent Hale to consult with Union General George B. McClellan in Grafton. McClellan ordered the Seventh Ohio Infantry under Colonel E.B. Tyler, which was just arriving by train in Clarksburg, to move immediately to Weston. McClellan sent this message to Tyler: "Get your troops to Weston, Lewis County, at once. Confiscate all the gold in the Weston bank, by force if necessary. Ship it to Governor Pierpont at Wheeling. Hurrah for New Virginia!’31

Marching overnight, the troops arrived in Weston at dawn on Sunday morning, June 30,1861, awakening the town's citizens by marching into Weston with fife and drum. The Exchange Bank was located in the ground floor of a large residence on the corner of Center and Bank Street. The bank's cashier, Robert J. McCandlish, lived on the second floor and that morning opened the door to find himself facing three rifles. McCandlish, a Union supporter, opened the vault and handed over the twenty-seven leather drawstring bags holding $\$ 1000$ each in gold coin. He protested that he should be left enough to pay the men who had been working on the building of the asylum, but the troops confiscated it all. The heavy bags were transported by wagon across the river from downtown Weston to the construction site of the asylum. There the troops set up camp, and the next day the money was taken to Clarksburg, put in armored boxes, and transported by train to Wheeling, where it was used to finance the "Reorganized Government of Virginia." Without this money, the government might not have been able to establish the new state of West Virginia in 1863. ${ }^{32}$ These funds were repaid to Virginia sometime after the Civil War..$^{33}$ 


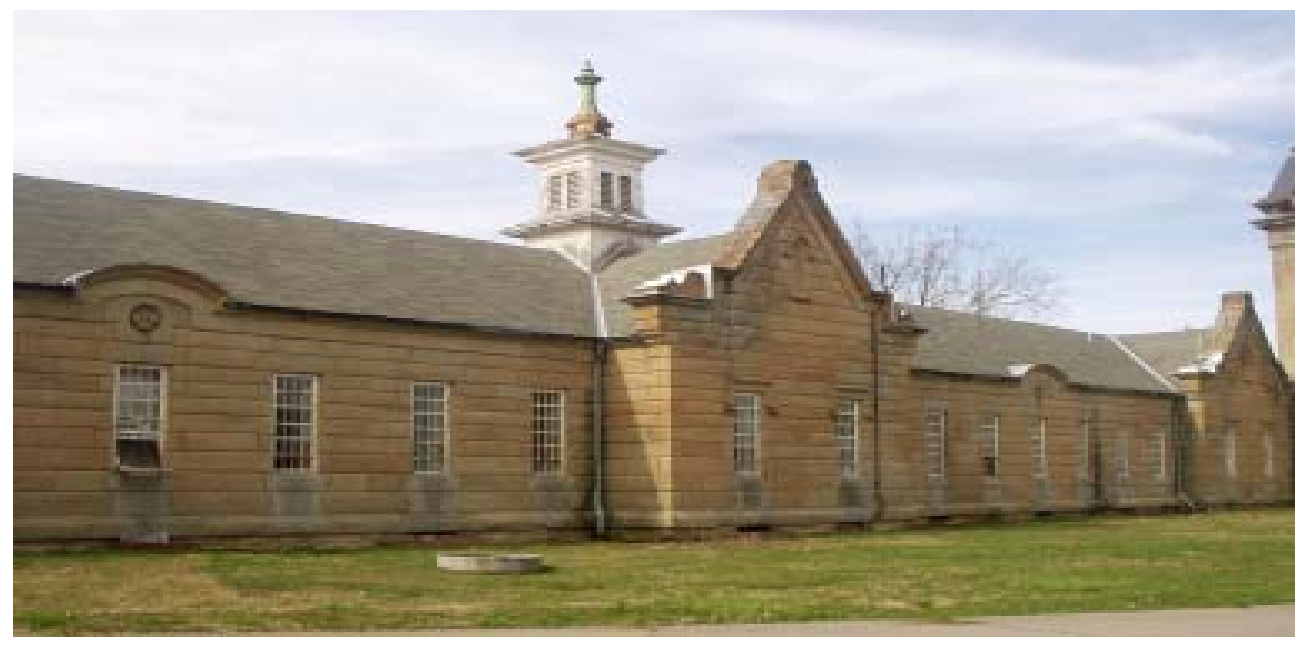

First section constructed, now called the "Civil War wing."

The town of Weston now commemorates this event with a reenactment each year of the "Great Weston Gold Robbery."

The new state government of West Virginia changed the name of the asylum in 1863 to the "West Virginia Hospital for the Insane," the name it retained until 1915. ${ }^{34}$ Work on the asylum continued through the rest of the Civil War. A report to the state of West Virginia from the Board of Directors, signed Dec. 21, 1863, described the progress of construction. The nearly completed one-story section was 220 feet long and twenty-nine feet wide. It had three wings running back from it at a right angle, each 120 feet long, with

A note about the name

1858-1863: Trans-Allegheny Lunatic Asylum 1863-1915: West Virginia Hospital for the Insane 1915-1980: Weston State Hospital 1980-1994: Weston Hospital two that were twenty-seven feet wide and the other nineteen feet wide. Three cupolas, covered in tin, provided ventilation for this section. A twelve-foot wide hallway ran the length of this section, and the two wider wings

had main hallways also. The third wing was a gymnasium. At this point they were waiting for the mortar of the floors to dry before laying the wooden flooring, which was prepared and waiting. Oak boards $13 / 4$ inch thick would form the floor planks. The heating system was being completed by John Sutherland, Esq., of Philadelphia, who was highly recommended by Dr. Kirkbride and had been the building superintendent for the Pennsylvania Hospital for the Insane. In October 1863, Dr. A.J. Hall, M.D. had been selected Medical Superintendent of the hospital. He had spent the last fourteen months at the Pennsylvania Hospital for the Insane and was also highly recommended by Dr. Kirkbride. ${ }^{35}$ 
The adjoining south three-story wing was also under construction in 1863 and measured 520 feet to where it would meet the center building. The walls of this section had been constructed almost to the level of the ceiling of the first floor according to the December 1863 report. They had paused on the stonework in mid-November, anticipating inadequate funds, and had covered the walls with planks to protect them from frost. Seventy-five logs had been cut and sawed to provide this covering. Extensive excavation had been done in preparation for the construction of a kitchen and laundry, a boiler house, an engineer's house, and space for the brick stack. A main sewer for this wing, 520 feet in length, required an eight to ten foot wide and ten to thirteen foot deep excavation. The sewer was thirty-six inches wide, constructed of brick, and laid in hydraulic cement. This was to receive sewage from various pipes in the three-story wing, and it ran to Polk Creek, a small stream nearby, into which it discharged. The report stated, "This sewer was a tedious and expensive job, as it should have been done during the summer, while the weather was dry, it having been put off until the fall rains set in, thereby increasing the expense very considerably." ${ }^{36}$ Other extensive excavation on the grounds was reported as well, leveling and grading and removal of rocks and carting them away. Much labor was done in clearing rubbish and stone from the basements. The report stated, "This was a heavy job." 37

Thirty-six hundred dollars had been paid out to furnish the one-story section. This included hair mattresses, ticking, bed linens, chairs, glassware, brushes, and various other items. A contract for forty walnut bedsteads and an order for window guards and screens,

The building was constructed with many artistic details.

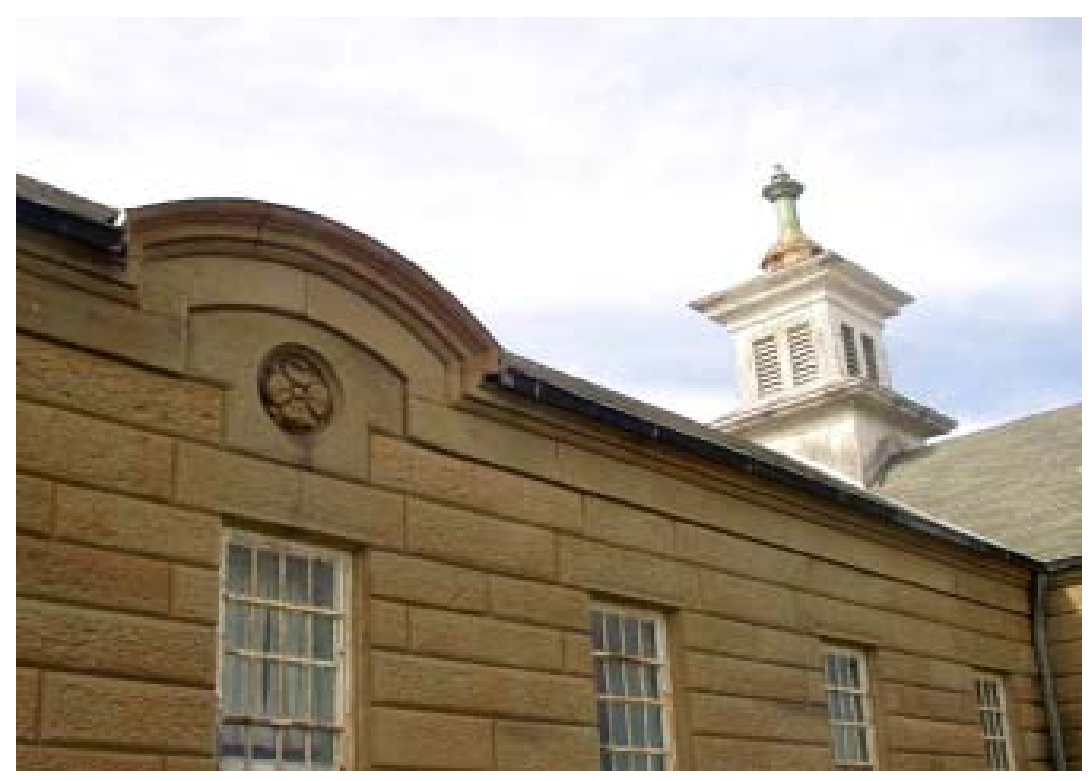


locks, and other items were also included. The board of directors made excuses in this report as to why the one-story buildings were not quite ready. They explained that much of their money had been used on the three-story part of the south wing. Also, several projects should have been started earlier in the season before the fall rains began—drainage culverts, mortar between the floors, the main sewer, the main ventilation stack, and the plastering. Much of this work had been suspended due to wet, cool weather, or had continued, but at greater cost and more trouble than it would have in the warmer seasons. ${ }^{38}$

As work continued on the hospital, there were two "very considerable rebel raids." General Jenkins had taken over Weston on August 30, 1862. Then Generals Jones and Imboden did the same on May 1, 1863, "the latter remaining here from Saturday until the next Wednesday following, subsisting their forces upon the country passed through." In the middle of October 1863 there was another raid "from the direction of Bulltown" [Braxton County]. The report stated:

In their several raids, all our workmen were driven off, tools scattered and stolen, and much lumber burned, thus losing from one to three weeks each time, before we could collect our hands, supply lost tools, and sufficient confidence restored to prosecute work again. On the second day of April, 1863, in order to keep our hands at work, we found it necessary to increase their per diem twenty-five per cent, as it was important that the work should be prosecuted. At the same time, we also increased the pay of John May, Esq., our Superintendent, from eighty-five dollars to one hundred and twentyfive dollars per month. ${ }^{39}$

This 1863 report was signed Board of Directors: Minter Bailey, Pres't., Elias Fisher, H. Daugherty, John W. Peterson, J. Woofter, Edw. M. Tunstill. ${ }^{40}$

Dr. Thomas B. Camden, a Weston physician who later became superintendent of the asylum, wrote of the raid on Weston by Confederate troops arriving from the Braxton Road. Dr. Camden was at the hospital, which was not yet opened but had many supplies ready in order to receive patients, such as blankets and bedding. He described how he saw the Confederates approaching on horseback on the Braxton Road, yelling and firing pistols and riding at full speed. He and the others at the hospital headed for their homes. The soldiers robbed all the businesses and many individuals in Weston. Dr. Camden had a pair of boots stolen but the soldier later returned them, setting them inside his fence and explaining that they were too small. The Confederates took the blankets that had just been received for the new hospital as well. On two other occasions the hospital also lost blan- 
kets. One set was stolen from a $\mathrm{B} \& \mathrm{O}$ train that had set out from Baltimore in January of 1864 but was stopped by Confederates. Patients were being admitted to one wing of the hospital by that time, and the hospital had to borrow blankets from people in the community. At the end of the war a shipment finally arrived. ${ }^{41}$

The grounds of the asylum were used as a camping site by the armies of both the Union and Confederacy on different occasions throughout the war. The nearly completed wing was said to have been used for barracks and for stables. ${ }^{42}$ According to the 1863 report the Confederate raids only lasted a few days, but they set back construction about three weeks on each occasion. ${ }^{43}$ Finally, in the autumn of 1864, twenty patients were admitted to the new asylum. ${ }^{44}$ After the war, patients from what was now West Virginia, who had been held in the asylums at Williamsburg and Staunton, were transferred to Weston. The state of West Virginia had to pay the state of Virginia over $\$ 23,000$ for the maintenance of these patients from June 20,1863 (the beginning of West Virginia statehood), to January $1,1866 .{ }^{45}$

The Annual Report from 1867 stated there were forty-five patients housed at the hospital. They and the employees and superintendent lived in the south one-story wing. A request was made for more in-door amusements for the patients:

It does not require one to be very familiar with life in a lunatic hospital, to understand how essential it is to success in treating a diseased mind, to be able in some way to divert it from preying constantly upon itself. This can be done in no better way than by furnishing a variety of pleasant amusements, combined as far as possible with instruction. With the exception of one or two musical instruments, the Hospital is in a manner destitute in this respect. ${ }^{46}$

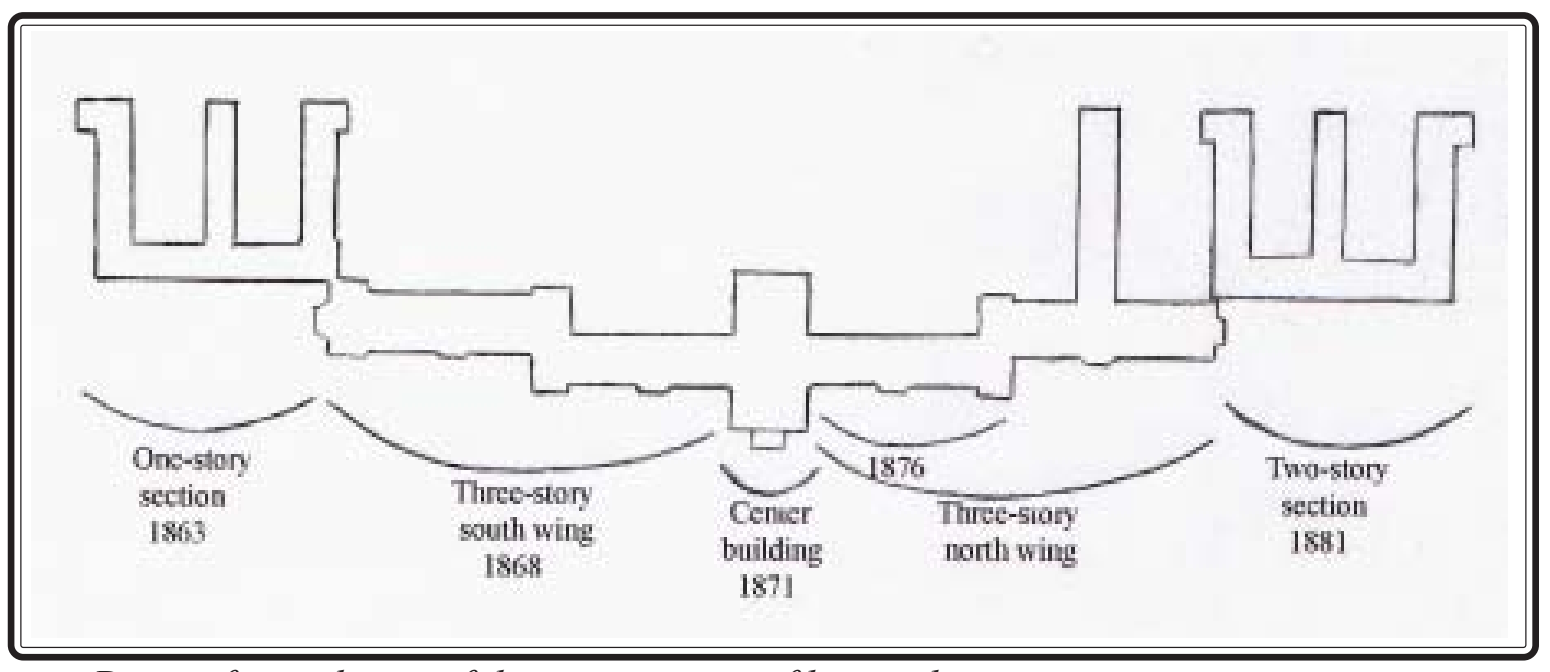

Dates of completion of the construction of hospital sections. 
The report further noted that construction was almost complete on the three-story section of the south wing, which would lead up to the center building. The walls were up, the wood work of the roof was in position, and slate was being put on it. They expected to be able to open this section in April of 1868, and would have the furnishings ready at that time so as to be able to quickly receive more patients. They were preparing furnishings and manufacturing bedsteads in their own shops. There was a plan for a railway to be built in the basement, so that the food could be easily distributed to dumb-waiters and elevated to the eating rooms

List of Offecer and Employses of the Hospital, and their salaries, et the preatent dote.

R. Hills, M.D., Euperintendent.,

A. H. Kunst, M.D., Asslatant Phyaician

Mrs. Emily G. Hills, Matron.

Mrs. Fannie H. Ely, Assistabt Matron.

Miss C. E. Roberts, Supervisor.

1.6.

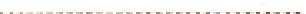

Jacob Nicoles, Attendnnt

F. B. Steinbeck,

J. G. Apple,

J. W. Walker,

James MeWeleh

Mrs. Mary Alexander, At

Mary Bcbaffer,

P. Turner,

Phebe J. Teter,

Virginis Alexnnder,

Margaret Moran,

Roanns Wert, Ḧoneekeeper

H. MeNemar, Cook.

Etiza Bradburry, Cook

Mary A. Stneel, "

Mary J. Heckart, Laundres:

Mrs. J. Poreman, Seamstre89........................... .... nn.........

Mary L. Foreman, Irover..

Peter Simmons, Tenmeter.

Holdoridge Alexander, Farm Hand ...................................

D. Feagens, Enginoes, (withoat board)

Jas. Bi Lorott, "is (withod

Thas, Bosh, Fireman,

a 4 "

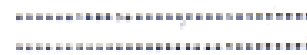

Wm. H. Bragg, Night Wateh, (withoat board)

1870 employee list. Note the disparity between men and women attendants' salaries.

(Public Documents, West Virginia and Regional History

Collection, West Virginia University Libraries)
Lucy Hymes,

in the various stories. A later report mentioned this railway, which connected the kitchen via a tunnel with the main hospital building. The railway ran under all parts of it, and the food was raised by dumb waiters to all the wards. ${ }^{47}$ For lighting, they had been using lamps and carbon oil, but this was not considered safe, economical, or convenient. Pipes for gas were being installed as the building progressed. ${ }^{48}$

The planned central section of the building would contain the kitchens, store room, dispensary, offices for business, receiving room, chapel, principal entrance and main hallway, homes "for the Superintendent, Matron, Assistant Physician, and other officers, and sleeping rooms for all the employees, from the highest to the lowest. Until that is done, these necessities must be temporarily and imperfectly provided for in the departments intended for pa- 
tients, thereby necessarily restricting their room and their numbers." ${ }^{\prime 49}$ Cost of the center building was estimated to be $\$ 71,367$. Additional costs for heating, furniture, and fixtures would be $\$ 10,000 .^{50}$

As of Oct. 1, 1867, the report listed that nineteen patients had been admitted that year and forty-five had been discharged. ${ }^{51}$ There were presently forty-five patients. There had been several applications for admission by "colored insane persons of both sexes." These had been refused because the directors reported they "had no special accommodations for that class. Their admission into the wards with whites is very properly refused in all the hospitals in the country. The insane are particularly sensitive as to their associations, so that tawny skinned Caucasians are not infrequently objects of suspicion and contempt, and sources of irritation." ${ }^{52}$ They went on to say that these patients should be provided for, but by building a separate facility for them or an appendage to the main hospital, and suggested $\$ 10,000$ should be enough to house twenty-five or thirty "colored" patients. ${ }^{53}$

Substantial fences around farm had been completed, amounting to one mile of fencing. Part of the land was to be cultivated and part was to be pasture. Twenty acres had been cleared, and fifty more had been "cleaned up and underbrushed." Production that year had included: 1000 bushels of corn, 300 bushels of Irish potatoes, and twenty of sweet potatoes. In addition, they had produced 150 gallons of molasses from sorghum and great variety of garden vegetables. The report also noted that the ladies department had made all the clothing for the patients, including coats, vests, pants and shirts for men. They had also made bed ticks, sheets, and pillow slips for one hundred new beds. ${ }^{54}$

In 1868 the West Virginia legislature appropriated $\$ 228,000$ for completion of the buildings, and the number of patients increased to almost two hundred. ${ }^{55}$ The 1869 annual report, however, stated that no work was done on construction that year, except for the preparation of some materials for future use "for want of necessary funds." Patients were being cared for at a weekly cost of $\$ 2.34$ per patient. ${ }^{56}$ In September of 1869 , complaints were made that there were still seventy-five insane persons in county jails and that too much money was being spent on walkways and fishponds at the hospital instead of housing. In 1870, $\$ 110,000$ was appropriated for buildings, and that year over fifty men were employed to construct the central building. ${ }^{57}$ An 1871 issue of the Weston Democrat, the local newspaper, described the clock and tower: "The large clock in the cupola will soon be finished. It will be like some politicians, having three faces. The large bell, which tolls the departure of the hours, can easily be heard for some miles around." ${ }^{\prime 58}$ The central 
building and the south wing were completed in the fall of 1871. A formal opening was held that included a visit from the governor and the board of directors, with a banquet and grand ball in the large ballroom in the central building. The central building was 130 feet long and seventy-two feet wide and four stories tall. ${ }^{59}$ The hospital was considered one of the best buildings of its kind in the United States. ${ }^{60}$

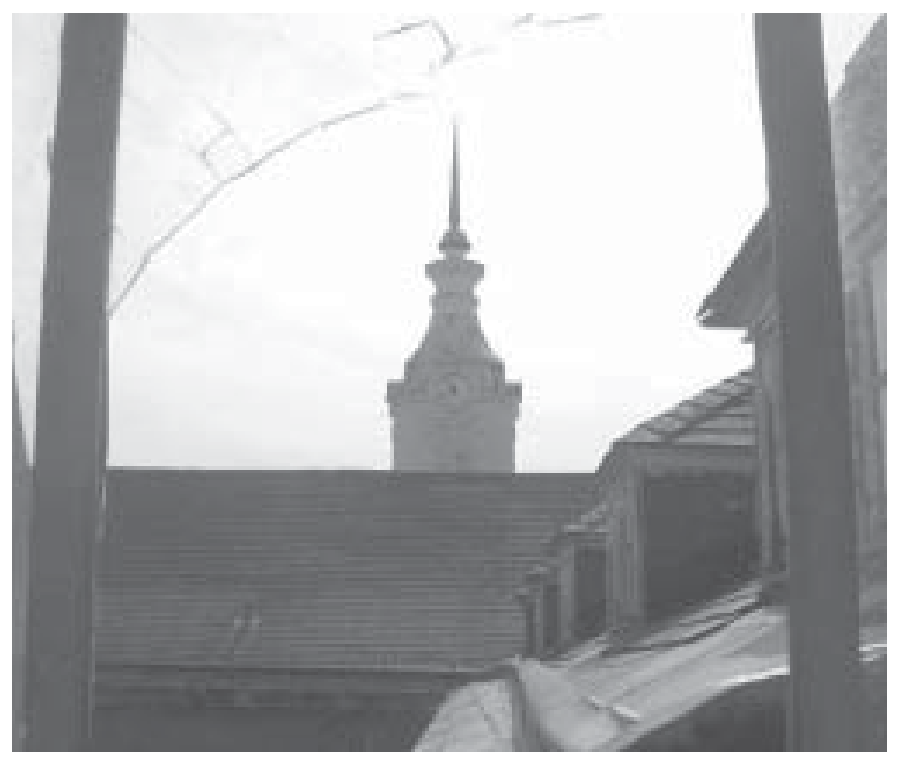

Clock tower in 2008.

Dr. Thomas B. Camden took over as superintendent in 1872 and oversaw the completion of the construction work over the next several years. In 1873 a new brick building was constructed to provide room for the "colored" patients. ${ }^{61}$ By 1876, the first section north of the center building (on the right as one faces the hospital) was completed, and this made room for an additional ninety patients. ${ }^{62}$ The 1876 annual report noted that two new lightning rods were placed on the clock tower. This was necessary to replace one that had been melted and destroyed. The superintendent realized this was very dangerous because there would be no way to extinguish a blaze if the tower caught on fire, due to its height. ${ }^{63}$

The north wing of the hospital was completed in $1881 .{ }^{64}$ The last section of the north wing was originally planned to be a one-story structure, like the south wing's end section. The lay of the land, however, would have required considerable fill, and the basement would have needed twelve-foot walls in order to match the rest of the building. Therefore the decision was made to instead build two stories in this section and provide more room for patients. The cost was less than it would have been to fill in the area with earth to reach the necessary height. ${ }^{65}$

The heating system required a twelve-foot fan and engine, which were installed in a fan house built seventy-five feet from the main building. This fan could throw 80,000 to 100,000 cubic feet of air into the hospital every minute, and it could change out the air in the entire hospital in two to four minutes. Tubular air ducts, seven feet by eight feet and lined with brick, connected to the main building's basement. Flues ran from the basement 
up to the rooms. In the winter this system brought heat, and in summer it brought fresh, cool air. ${ }^{66}$ The waterworks were completed and the cemetery laid out, and in 1887 another new building was completed and was quickly filled. ${ }^{67}$ The total cost for the main hospital building was $\$ 625,000$, and $\$ 100,000$ was spent on the land and other buildings, for a total of $\$ 725,000 .{ }^{68}$ In 1890 construction was begun on a second state hospital for the insane at Spencer, West Virginia. ${ }^{69}$

The West Virginia Hospital for the Insane, when completed in 1881, was 1295 feet long, covered by three and a half acres of slate roof, and had nine acres of floor space. There were over fifteen miles of steam pipe to deliver heat to the wards. ${ }^{70}$ Over the central administration section was the 200-foot clock tower. Four lower cupolas reached 150 feet in the air. The sandstone walls were two and a half feet thick and backed in the interior by brick and then plastered. The building held 921 windows and 906 doors. A full basement, with dirt floor, ran the length of the building. ${ }^{71}$ It has been said that the building is the largest hand-cut stone building in North America. At one time it was purported to be the largest hand-cut stone building in the world, as a National Geographic Magazine article described it in the 1920s, but this was disputed, so the claim has been limited to the largest in

The ballroom in 2008. Note the chair to gauge the size of the room. It is two stories high, with a stage and movie projection room.

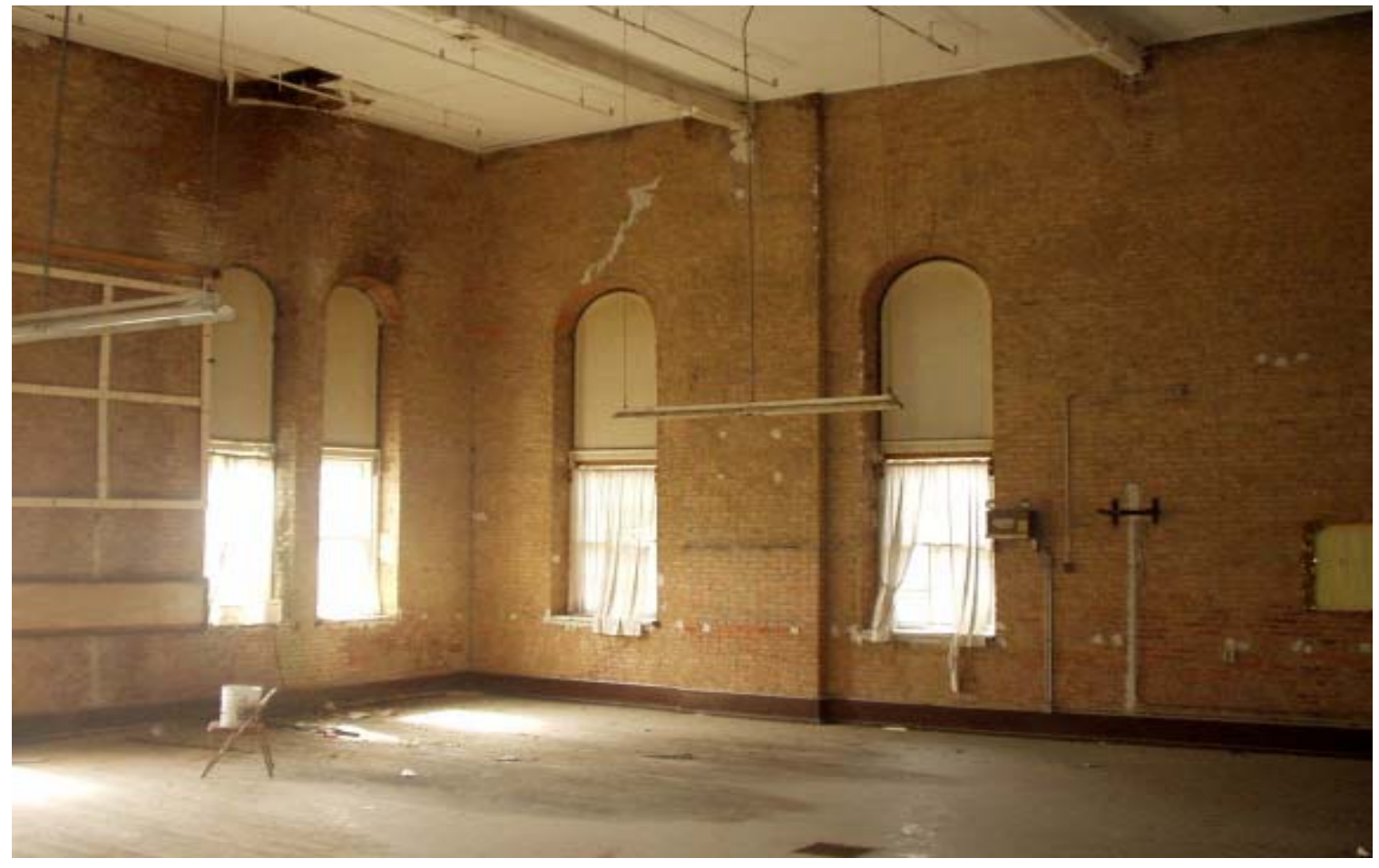


North America. There may be larger stone buildings, but it is the band-cut stone that made this one so notable.

As anticipated, the building of the hospital had a positive impact on Weston's economy. Weston had grown before the Civil War, particularly with a housing boom on the west

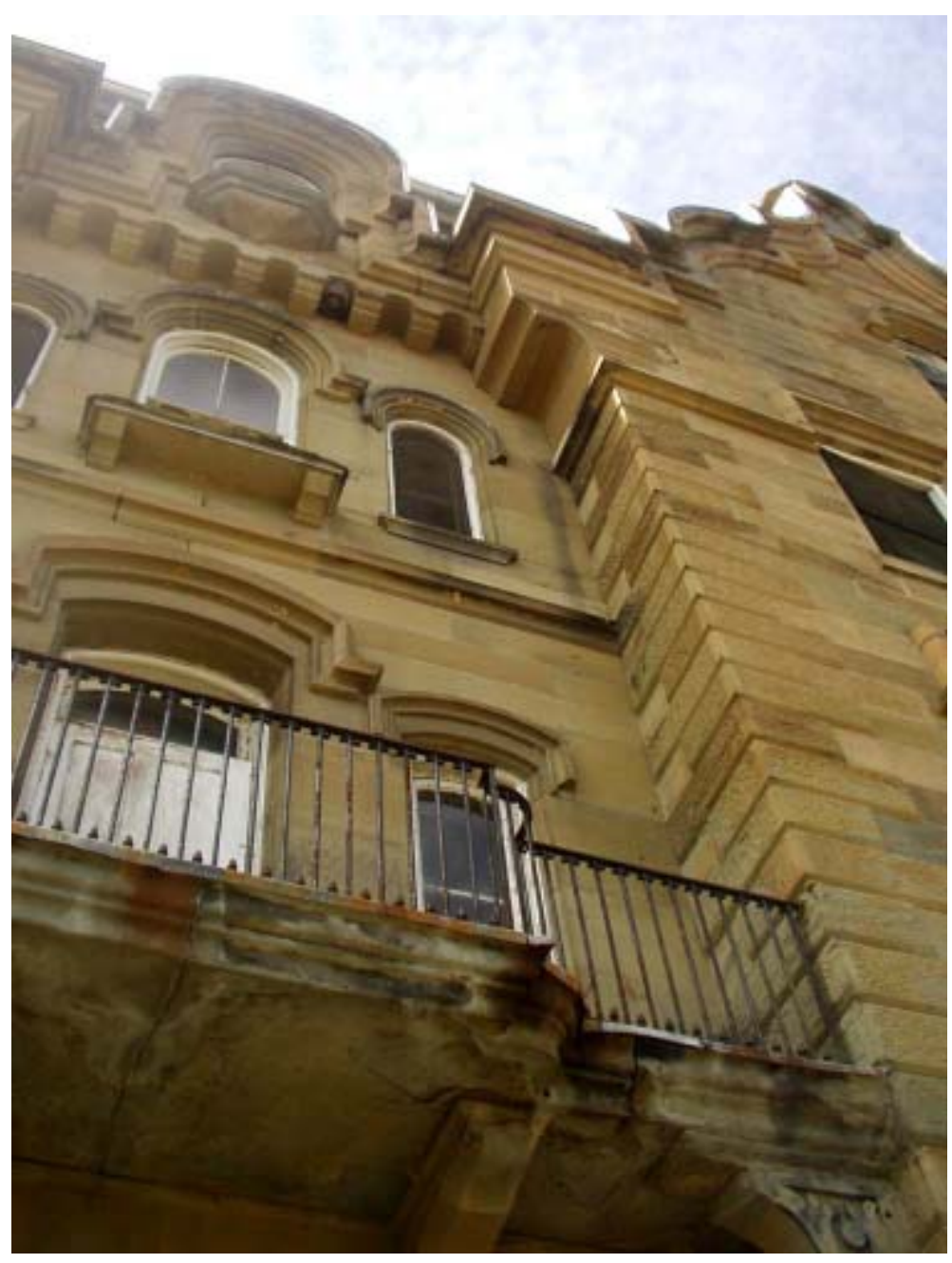

Front of the center building, viewed from porch roof, 2008. side of town in anticipation of the needs of workers constructing the hospital. Lewis County recovered more quickly after the Civil War than other West Virginia counties. There were more dollars in circulation there as a result of hospital construction, and businesses grew. Many skilled artisans were attracted to Weston, and most of them decided to stay there. The payroll of the hospital and purchase of supplies from businesses spurred the economy. The timber industry grew as thousands of feet of oak and poplar boards were sold to the state for the buildings. Many farmers cut logs, hitched them to a team of oxen and hauled them to Weston, where the lumber was sawed at the mill on the hospital grounds. It was an easier way to get money for taxes than other methods such as gathering ginseng had been. The National Exchange Bank grew with the growth of trade, more businesses opened, and more lawyers and doctors began practicing in Weston. The increased prosperity of the town also allowed new churches and schools to be built. The hospital had its own farm, but it was not able to provide all 
the grain, vegetables, and dairy products necessary for the patients, so local farmers were able to sell butter, berries, and garden vegetables to the hospital. ${ }^{72}$

A visit to the hospital by the editor of the Wheeling Register resulted in an account reprinted in the Weston Democrat in 1871. He reported 242 patients residing there in eight wards, or hallways. All bedrooms were nine feet by twelve feet in size and opened to the hall. Each ward had a parlor, dining room, and bathroom. He described everything as very clean and neat and pleasant. The rooms were light and cheerful and the "inmates" clean. He went on to describe some of the patients he met:

Like all other institutions of this kind, the Asylum at Weston had its celebrities. One old man thinks himself the Creator of the Universe and delivers orations and toasts that are wonderful for their pomposity and extravagant incoherence. He attempted to prove to Governor Jacob and the Board of Directors and the visitors who were present last Thursday that the elephant is the greatest and first of all the Gods, and he summoned the turtle as his witness. Another man has two ribs which he says belonged to the body of Adam. He carries them with him, tied by a leather thong. Another insists that he died in 1791. Another old man is very positive he is dead and is importunate in his demand to be burned up. He says he has to be burned up some time, and it might as well be done at once.... Another spends his time in drawing pictures, beside which the sketches of horses, dogs and houses delight idle urchins at school are gems of fine art. A woman about forty years of age imagines herself a baby of about six months and cries and bawls to perfection.

Some of the patients are suicidal and have to be carefully watched; others are homicidal and have to be restrained; but a large majority of them are peaceably disposed but are utterly incapable of taking care of themselves. Many of them, however, may work under direction of the attendants, and accordingly they are employed upon the farm and in many occupations about the house. The women do plain sewing and knitting; the men assist in the laundry, bake-house, carpenter shop, quarry, etc. One of the patients, who was for a number of years insane, and still has periods of occasional insanity, has made, with his own hands, nearly all of the finer furniture in the office and rooms of the Superintendent and other officers. The furniture is very beautiful in design and is very skillfully and substantially made. ${ }^{73}$

Reports from the 1870s describe the amusements provided for the patients. There were "billiards, bagatelle, cards, dominoes, and draught" on the wards. [Bagatelle involved rolling balls into scoring areas, and draught was checkers.] There were regular Friday 


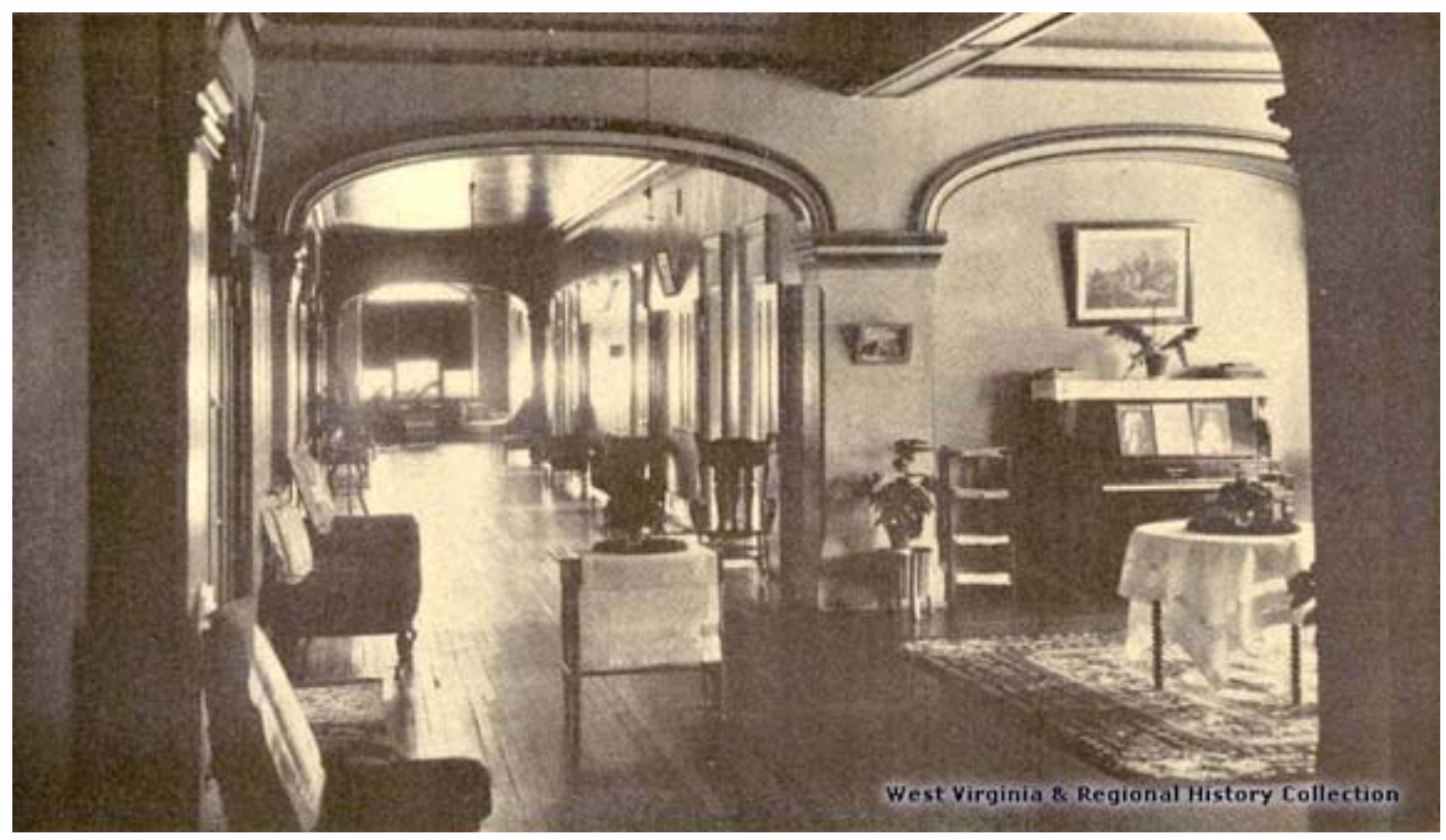

A women's ward, 1900.

West Virginia and Regional History Collection West Virginia University Libraries

evening dances, which were greatly enjoyed. A wagonette was run daily in good weather and took eight females around at a time. There was also a pony phaeton [a light, fourwheeled, doorless carriage with one or two seats] used every evening around the grounds by the female patients, with each ward taking turns. ${ }^{74}$ The early asylum was undoubtedly a more pleasant and agreeable place than it would become over the next few decades as it became increasingly overcrowded. Photographs of the hospital at the turn of the century show it as strikingly beautiful. Several photographs of the early hospital included in biennial reports to the state government depict quite lovely parlors, dining areas, and wards. Unfortunately, this was not to be maintained over the next century.

\section{Managing the West Virginia Hospital for the Insane}

Dr. Kirkbride's ideal of a mental institution with no more than 250 patients was soon forgotten as state asylums, including the West Virginia Hospital for the Insane in Weston, admitted more and more patients. The 1880 Report of the Board of Directors and Superintendent of the hospital to the governor of West Virginia reported the hospital to be "as full as capacity will allow," with 491 patients. Costs were modest, with each patient being cared 
for on $\$ 2.17$ per week, which included the salaries and wages of employees. ${ }^{75}$ The hospital was set up to be largely self-sufficient, though it still purchased many items such as beef, butter, and bacon. The farm had barns and livestock and gardens. The patient clothing and most of the furniture, even mattresses, were made at the hospital, most with patient labor. There were many buildings on the entire complex besides the huge main stone building, including an ice house, smoke house, boiler building, laundry, several shops and houses, a bakery, and the "colored building." 76 Later, additional acreage was added to total 666 acres. Eventually there was a reservoir and water treatment plant, oil and gas wells, working coal mines, and a morgue and three cemeteries. ${ }^{77}$

The 1880 Report said there were 467 white patients and 24 black. Discharges for the year were listed as twenty cured, fifteen died, and thirteen "improved on bond," or discharged conditionally. Many new patients had recently arrived after the completion of the hospital; 86 were admitted in twenty days. Most of these had been in jails for years, and many were epileptic. There were patients of all ages and types of insanity. One eight-yearold boy had been quickly handed off by his mother at the train station; she said he had A portion of the 1870 patient list for the
West Virginia Hospital for the Insane.
Public Documents of West Virginia West Virginia and Regional History Collection

West Virginia Universtiy Libraries

TABULAR STATEMENT OF ALL UNDER TREATMENT DURING THE YEAR-Contimud.

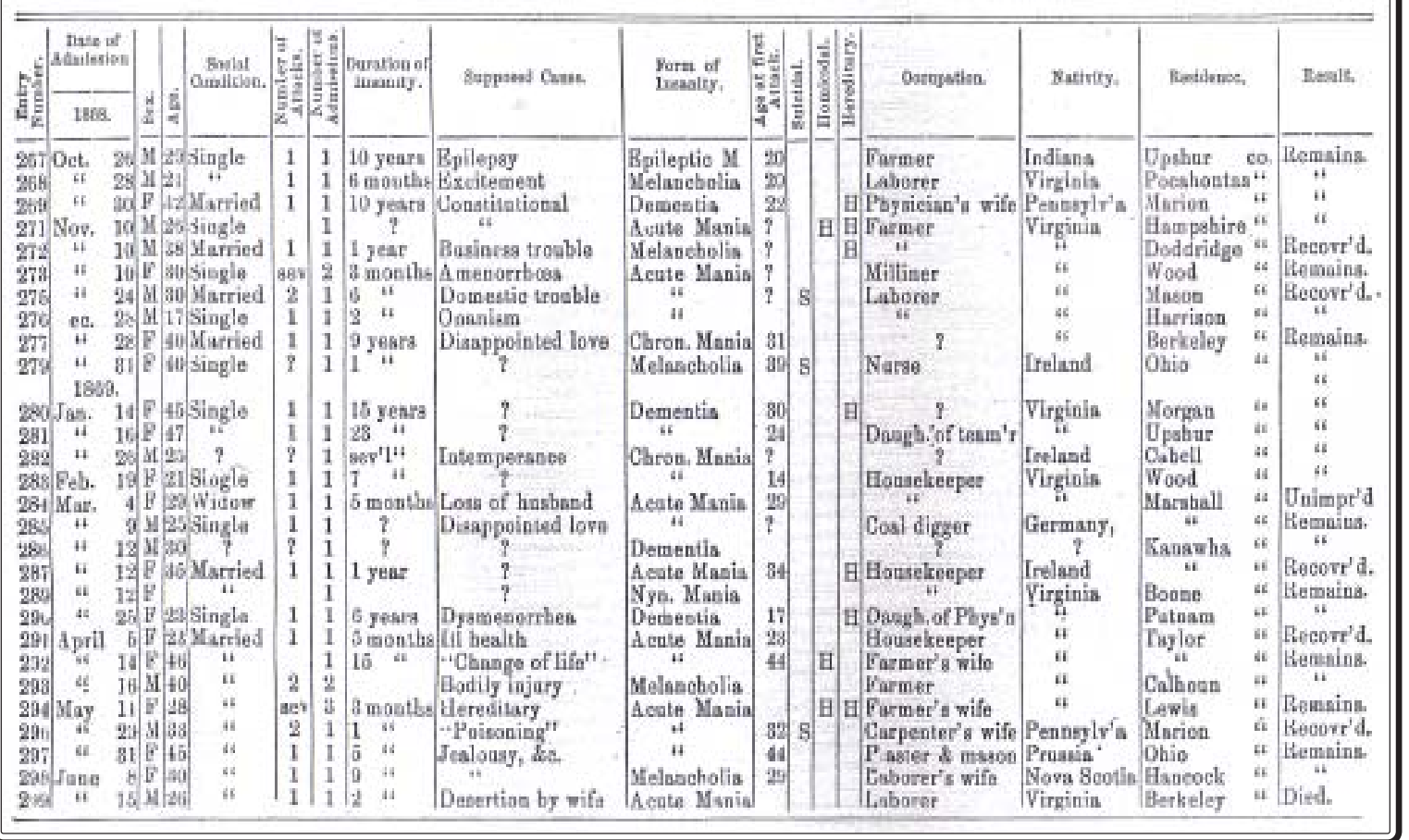


been insane since age three. The oldest patient was 93 years old. ${ }^{78}$ The diseases attributed to those admitted to the hospital from its opening in 1864 through 1880 were varied, with the most common being 304 patients with chronic dementia, 254 with acute mania, 225 with melancholia, and 165 with chronic mania. Listings were given of the supposed causes of the diseases, and they were labeled supposed causes, with the physicians of the time feeling "a little uneasy with them," though they still published them. ${ }^{79}$ Most common at Weston were the 359 who were "not assigned" a cause, and "heredity" (101), and "epilepsy" (70) ranked next. Forty to fifty patients were attributed each of the following causes: "intemperance," "ill health," "menstrual," "traumatic injury," and "masturbation." One honest man was listed with "masturbation for 30 years." "In the late nineteenth century, one of the common causes for admission to mental institutions was listed as masturbation. Dr. Turner H.R. Smith of Fulton State Hospital in Missouri, wrote: "I very much fear this pernicious habit, with all its withering influence upon mind and body, prevails among the young of both sexes to an alarming extent....the expenditure and exhaustion of nerve power, resulting from the frequent repetition of this habit, and the constant excitation to which the brain is thus exposed, slowly and permanently damage the delicate nerve cells, the supreme centers of life, and so wreck the unfortunate subjects, physically and mentally, as renders them among the saddest of the hopeless." ${ }^{\prime 81}$ The argument that masturbation caused mental illness was widespread in the nineteenth century, discussed in medical journals. ${ }^{82}$ Other common reasons given for admission were: "grief," "religious

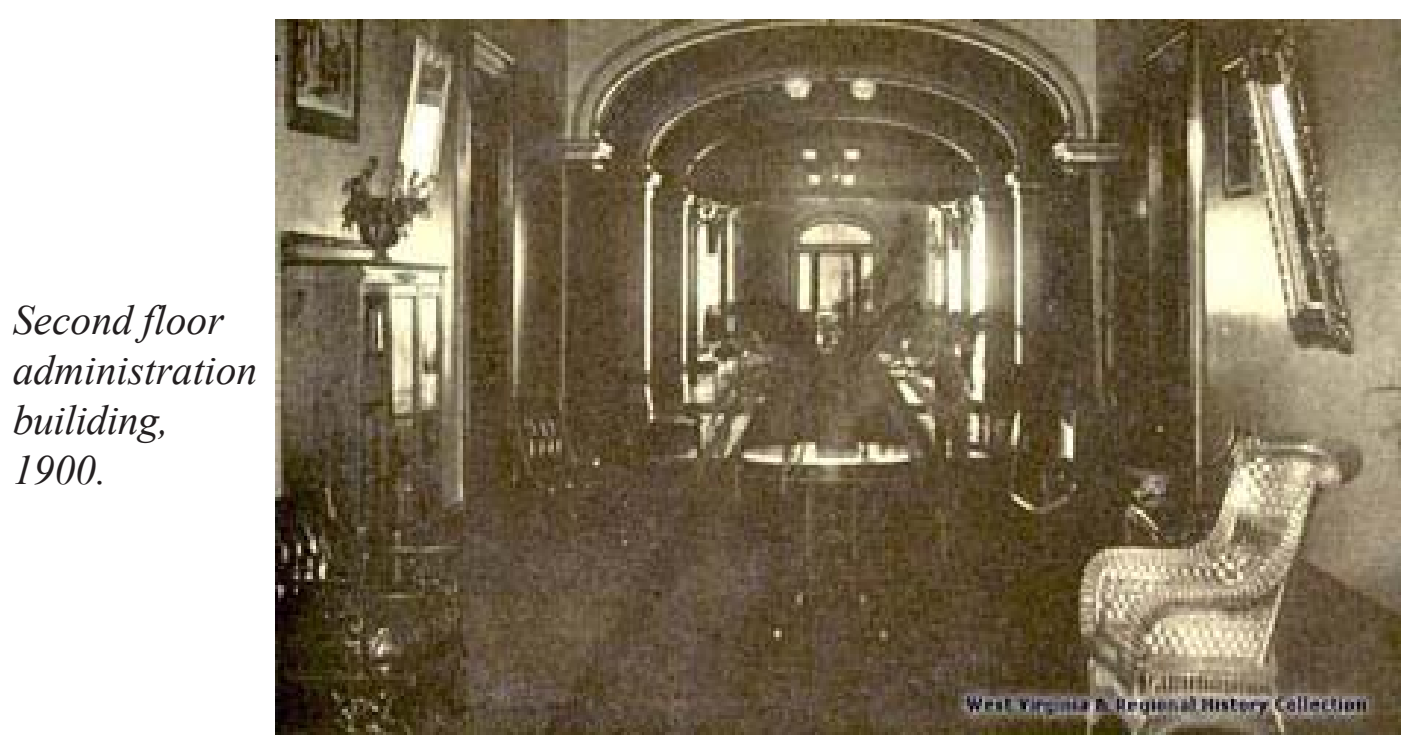

West Virginia and Regional History Collection West Virginia University Libraries 
excitement," "puerperal," and "uterine." Some were also: "mental perplexities," "the war," "hard study," "disappointed love," and "disappointment in business." 83 Some more unusual listings were: "novel reading," "doubt about his mother's ancestors," "vicious vices in early life," "marriage of son," "fever and loss of lawsuit," "Salvation Army," "seduction and disappointment," and simply "bad company."

Most of those admitted from 1864 through 1880 were natives of Virginia (recently become West Virginia). Seventy-one were born in Ireland and forty-seven in Germany. Several were born in surrounding states, and a few from other nations such as Prussia, Switzerland, Scotland, and England. Recoveries were listed as 269 out of 1124, a 26\% recovery rate. ${ }^{85}$ The "cured" rate was not nearly as high as those reported by the early

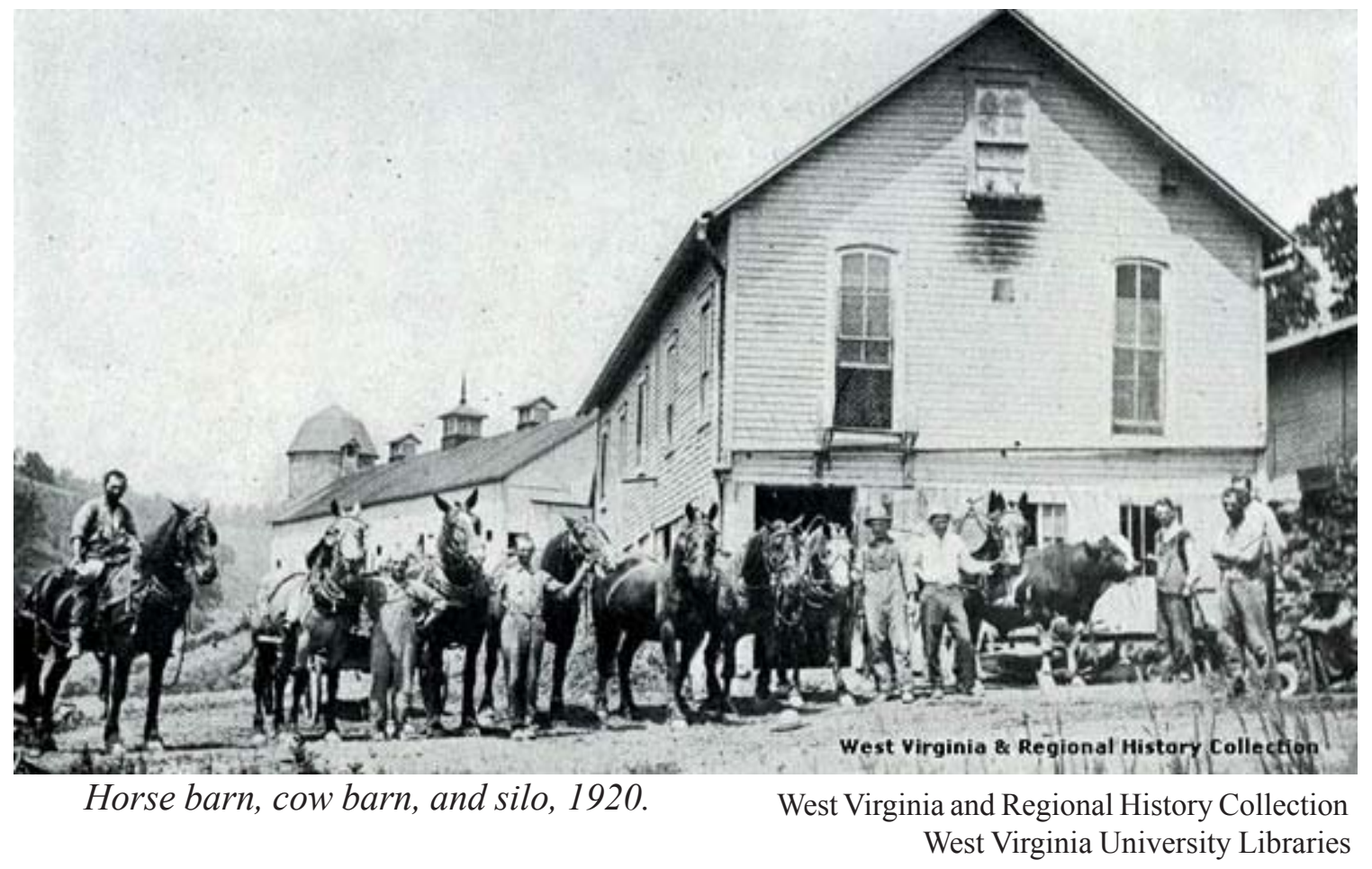

asylum superintendents, but by the 1880s overcrowding was occurring, with the ratio of caregivers to patients decreasing, and custodial care was becoming the norm. This report to the governor contained no information on treatment given to patients.

A glimpse of life at the institution can be gained from some information in the rest of the Biennial Report. A thank-you list included words of appreciation to state newspapers that contributed copies, to donors for the purchase of books, to entertainment groups such as the Jubilee Singers and the Thomas Combination troupe, to the CW \&G Railroad for 240 free tickets to ride to the county fair, to the Lewis County Agricultural Fair for 240 
free admissions, and to the ministers who officiated chapel services. The account also cited that some patients were involved in working at the hospital, noting that large amounts of grading and filling had been done by both patients and attendants. The report also listed expenditures for 1880 . One of interest was $\$ 145$ spent for eighty gallons of whiskey, but presumably this was for medicinal purposes or for the staff. Other expenditures were for foods, such as 74,000 pounds of beef at $\$ 4452$, and 23,000 pounds of butter at $\$ 2943$, and $\$ 1276$ for produce. ${ }^{86}$ This need for food products was obviously was boon to the local economy. If the hospital was purchasing 74,000 pounds of beef per year for nearly 500 patients and approximately 60 employees, that would be enough to provide one-third pound of beef per person for 342 days out of the year. Since expenditures also list almost 3000 pounds of bacon and 3000 pounds of pork, in addition to the pork produced on the farm, it seems that the patients were probably reasonably well fed at that time. A report of the food produced in the gardens and on the farm in 1890 lists an impressive array of products -700 bushels of tomatoes, 4692 heads of cabbage, and 7650 bunches of celery, among many other foods. The matron's report details the food that was "put up" in 1889, including over a thousand gallons of peaches, 900 gallons of blackberries, and 812 gallons of tomatoes. Also, almost 4000 pounds of lard and 2200 pounds of sausage were preserved that year. ${ }^{87}$

Information from the Lewis County portion of the United States Census for 1880 reveals that the hospital staff and employees resided at the institution. Apartments were provided in the administration building and there were other residential rooms and apartments throughout the buildings. The census shows that the superintendent, Thomas B.

Staff apartment in center building, 2008.

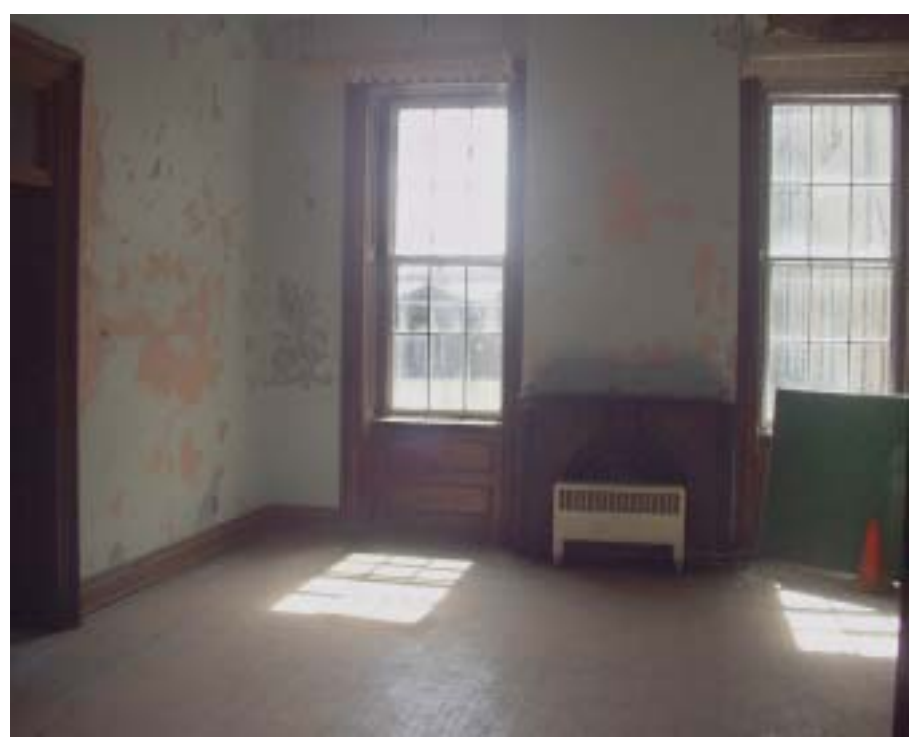


Camden, was 50 years old, and resided there with his wife, a daughter age 23, five sons, ages 21,18, 13, and 10 listed as students, and one age seven. Also residing at the hospital were the assistant physician, Albert Kunst, and his wife and their two young sons. There was another young assistant physician, aged 21 , and a matron with her two daughters. ${ }^{88}$

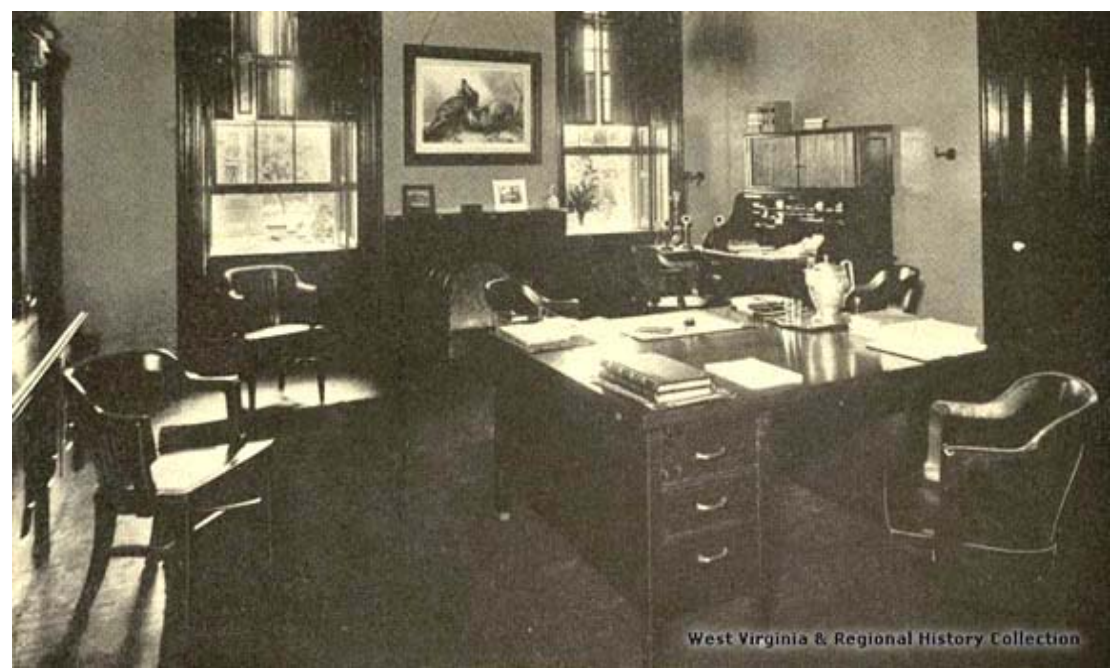

Superintendent's office.

The original handmade wooden shutters remain in a few windows in 2008.

West Virginia and Regional History Collection West Virginia University Libraries

The matron supervised the kitchen, bakery, dining rooms, laundry, and oversaw the house girls and cleaning. She also wrote requisitions for groceries and supervised storerooms. ${ }^{89}$ Other employee residents were a clerk, a seamstress, three cooks, a baker, an engineer, a nurse, a "center building girl," a "dining room girl," and four laundresses. Twenty-seven attendants were also listed, ranging in age from 19 to 72 . One male and one female attendant were listed as black. Most of the employees were born in West Virginia or Virginia, though one was English, two Irish, one from Slovenia, and one from Baden. Ten others had one or both parents born in Ireland, and five others had at least one parent from another European nation. It is interesting to examine the occupations of the patients before their admittance. Nearly a fourth were listed with occupation "unknown" or "none," but most of the patients had held employment of some sort, ranging from telegraph operator to millwright to glass blower to law student. Almost all of the women were listed as "keeping house" or "housewife," with a sprinkling listed as "seamstress" or "domestic servant." Many of the men were farmers or laborers. ${ }^{90}$

Mental hospitals in the mid-nineteenth century were generally set up on a strict schedule, with regular work providing structure and focus for the patients who were able. $\mathrm{Pa}$ - 
tients supplied all kinds of useful labor, including washing dishes, cleaning, doing laundry, and farm work. This kept costs down and provided a therapeutic routine for the participating patients. ${ }^{91}$ Early institutions had been able to avoid using restraints on patients, such as chains or straitjackets. At Dr.

Kirkbride's Pennsylvania Hospital, violent patients were not restrained unless there was danger of suicide. He also provided at least one attendant for every six patients and would not allow the attendants to authorize any restraints, thinking it would be too tempting for them to use them. Only physicians could authorize restraints. However, in most hospitals there were not enough attendants to allow the close supervision required if no restraints were used. As the number of chronic inmates increased in asylums, the more difficult it became to avoid use of restraints. ${ }^{92}$

Some of the forms of control used in mental institutions throughout the United States were the strait-

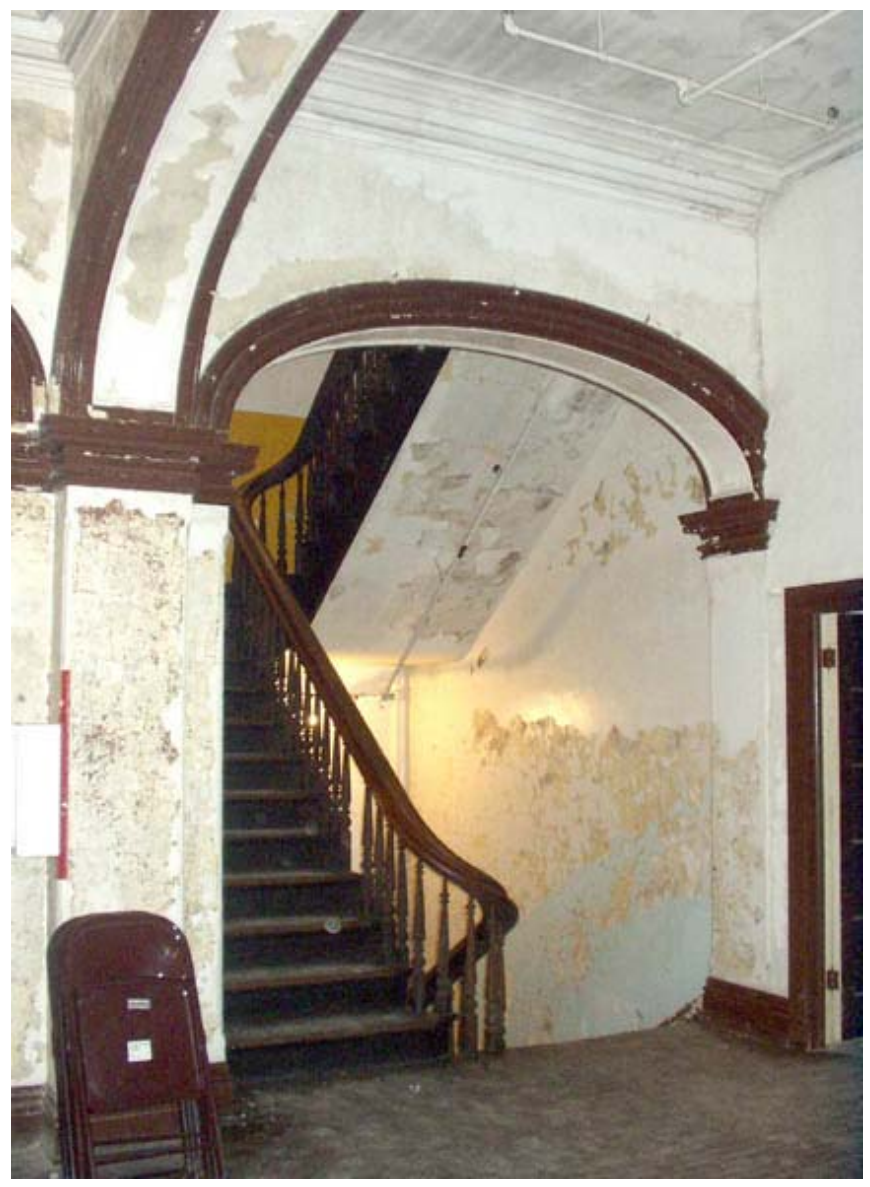

Stairway on second floor, 2008. waist, or straitjacket, "an ordinary jacket with the ends of the sleeves closed, fitted onto 'indifferent and careless patients who might, during cold weather, rip off their clothes otherwise." "93 This was usually used to hold the patient's arms across their body and then tied in back. A lock seat held a patient in a sitting position, and a crib was a regular bed with sides and a cover added to restrain suicidal patients. Leather wrislets, mittens and muffs were used to confine hands. Mittens were large, thick, and heavy and were attached to a leather strap that held them to each other. Some of the early treatments at mental institutions were drugs to stimulate patients, to calm them, and to cleanse the bowels. The plunge bath and dunking chair could "elicit a lively response" in the listless. Frenzied patients were put in cold water for extended periods to exhaust them. Bleeding or blister- 
ing patients "drained the system of harmful fluids, reduced inflammation, and refocused the patient's attention." 94 Some early doctors of the mentally ill, in colonial times, believed instilling fear in patients was useful - that the insane chose to lose their reason and if intimidated, could be convinced to come back into their right minds. ${ }^{95}$ Dr. Turner Smith of Fulton Hospital in Missouri preferred to use narcotics to calm patients. "I would part with any other remedy before I would give up opium," he reported in $1868 .{ }^{96}$ Other techniques that were believed to be helpful, according to a Dr. Charles Hughes at Fulton, "Laxatives to purge the system, tonics to restore strength and quiet, and various drugs to induce sleep. If, through the temporary administration of alcoholic beverages, the patient can be induced to remember his misery no more, we consider the treatment justifiable." ${ }^{\prime 97}$

By the late nineteenth century, most mental hospitals were not able to maintain their ideals for moral treatment but were becoming simply providers of custodial care. Insanity was not disappearing. Despite their faults, institutions continued being the method used to care for the mentally ill for a century longer. Because they were providing custodial care to so many people, they seemed essential. The patients who filled the institution were not what the superintendents had originally expected. They were not the "recently insane," but instead large numbers of chronic patients who were not able to respond to an orderly system of work and rehabilitation. The public was willing to accept that asylums had become custodial facilities, as many of the patients might be a danger to society, and many might be foreigners. Reform may have been what led to the building of these institutions, but their function as custodians perpetuated them. ${ }^{98}$

As asylums became increasingly overcrowded, superintendents were less and less likely to attempt to keep the patients busy. Classification of patients broke down also, and the more disruptive tended to mingle with the more peaceable patients. Discipline became harsher, with the use of straitjackets, cuffs, sleeves, bed straps, and cribs becoming increasingly common as methods of restraint. ${ }^{99}$ In the 1980s, a crib was found in the attic of the hospital in Weston. It was a large slatted crate, slightly larger than a coffin, and had been used to confine unruly patients in earlier times. ${ }^{100}$ By the late nineteenth century, former claims of the curability of insanity were now acknowledged as having been exaggerated. It was being recommended that patients with milder mental illnesses be treated at home. State legislatures often did not provide enough funding to adequately maintain the asylums, especially as they became more crowded, so superintendents had to make do 
with inadequate staff and materials. Also, state political parties began to use the employment in institutions as a way to reward supporters, so state hospital superintendents complained that their staff quality was declining. ${ }^{101}$

Gargoyles were incorporated into the construction of the stonework by the craftsmen who built the hospital.

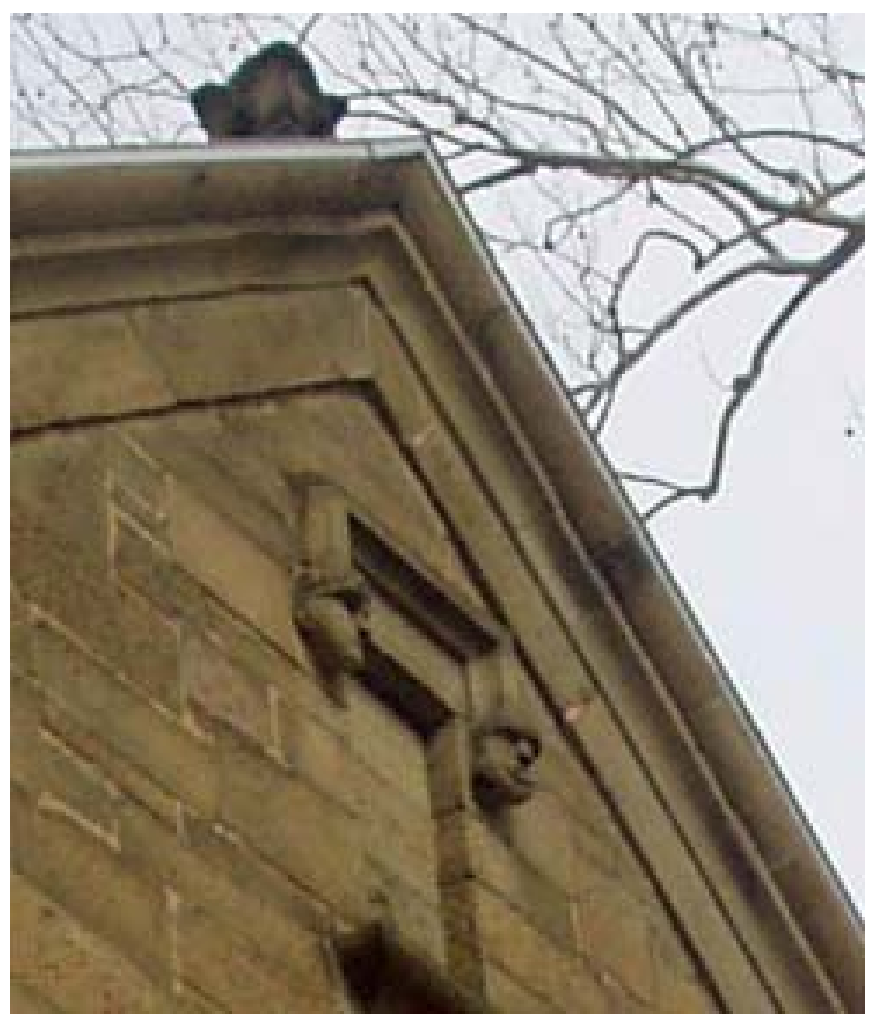


${ }^{1}$ Bill Alder, Yesteryears (Weston, WV: Hackers Creek Pioneer Descendants, 1983), 96-101.

${ }^{2}$ Edward Conrad Smith, A History of Lewis County, West Virginia (Weston, WV: the author, Morgantown Printing and Binding, 1920), 260.

${ }^{3}$ Marjorie Carr, Weston Hospital, 1858-1992 (Weston, WV: privately printed, 1992), 2.

${ }^{4}$ Joy Gilchrist-Stalnaker, A Short History of Weston Hospital (Weston, WV: Hacker's Creek Pioneer Descendants, 2001), 3.

${ }^{5}$ Smith, History of Lewis County, 260.

${ }^{6}$ Adler, Yesteryears, 103-104.

${ }^{7}$ Joy Gregoire Gilchrist and Charles H. Gilchrist, Lewis County, West Virginia: A Pictorial History of Old Lewis County, The Crossroads of Central West Virginia (Virginia Beach, VA: The Donning Company, 1993), 36 .

${ }^{8}$ Adler, Yesteryears, 102.

${ }^{9}$ Smith, History of Lewis County, 259-261.

${ }^{10}$ Ibid., 327.

${ }^{11}$ Gilchrist-Stalnaker, Short History of Weston Hospital, 3.

${ }^{12}$ Robert Whitaker, Mad in America: Bad Science, Bad Medicine, and the Enduring Mistreatment of the Mentally Ill (Cambridge, MA: Perseus Publishing, 2002), 21-24.

${ }^{13}$ Shomer S. Zwelling, Quest for a Cure: The Public Hospital in Williamsburg, Virginia, 17731885 (Williamsburg, Virginia: The Colonial Williamsburg Foundation, 1985), 23.

${ }^{14}$ Whitaker, Mad in America, 21-24.

${ }^{15}$ Zwelling, Quest for a Cure, 23.

${ }^{16}$ Whitaker, Mad in America, 31.

${ }^{17}$ Ibid., 31-33.

${ }^{18}$ Thomas S. Kirkbride, On the Construction, Organization and General Arrangements of Hospitals for the Insane (Philadelphia: J.B. Lippincott, 1880; reprint, New York: Arno Press, 1973), 33, 37-40.

${ }^{19}$ Ibid., 42, 62-64.

${ }^{20}$ David J. Rothman, The Discovery of the Asylum: Social Order and Disorder in the New Republic (Glenview, Illinois: Scott, Foresman and Company, 1971), 153.

${ }^{21}$ Adler, Yesteryears, 105, 107.

${ }^{22}$ Ibid.

${ }^{23}$ Gilchrist-Stalnaker, Short History of Weston Hospital, 3.

24 Carr, Weston Hospital, 2-3.

${ }^{25}$ Annual Report of the Directors and Superintendent of the West Virginia Hospital for the Insane for the year 1870 (Wheeling, WV: John Frew, Public Printer, 1871), 9-10.

${ }^{26}$ Smith, History of Lewis County, 330-331.

${ }^{27}$ Gilchrist-Stalnaker, Short History of Weston Hospital, 3.

${ }^{28}$ Trans-Allegheny Lunatic Asylum Time Book for 1860-1861, Microfilm A\&M 2193, West Virginia Collection, West Virginia University Library.

${ }^{29}$ Smith, History of Lewis County, 328.

${ }^{30}$ Thomas Bland Camden, M.D., My Recollections and Experiences of the Civil War or A Citizen of Weston During the Late Unpleasantness, annotated by Otis L. Reed (Parsons, WV: The Friends of the Louis Bennett Public Library/ McClain Printing Company, 2000), 1, 16.

31 “The Great Gold Robbery," Weston Gold Robbery Committee: The Great Weston, West Virginia, Gold Robbery, West Virginia’s First Treasury [Internet]; available from http://westongoldrobbery.com/ great_gold robbery.htm, accessed 30 March 2006.

${ }^{32}$ Ibid.

${ }^{33}$ Gilchrist-Stalnaker, Short History of Weston Hospital, 4.

${ }^{34}$ Fourth Biennial Report of the State Board of Control of West Virginia for the Period July 1, 1914, to June 30, 1916 (Charleston, WV: Tribune Printing Company, 1916), 45. 
${ }^{35}$ Annual Report of the West Virginia Hospital for the Insane, December 31, 1863. [No other publishing information - other reports beginning in 1868 are similar in binding and print and were published in Wheeling: John Frew, Public Printer], 3-4, 8.

${ }^{36}$ Annual Report, 1863, 4-5.

${ }^{37}$ Ibid., 5.

${ }^{38}$ Ibid., 2, 6.

${ }^{39}$ Ibid., 7.

${ }^{40}$ Ibid., 9.

${ }^{41}$ Camden, My Recollections, 82, 86, 94.

${ }^{42}$ Gilchrist-Stalnaker, Short History of Weston Hospital, 4.

${ }^{43}$ Annual Report, 1863, 7.

${ }^{44}$ Adler, Yesteryears, 118.

${ }^{45}$ Smith, History of Lewis County, 330.

${ }^{46}$ Fourth Annual Report of the Directors and Superintendent of the West Virginia Hospital for the Insane, for the year 1867 (Wheeling: John Frew, Public Printer, 1868), 5, 8.

${ }^{47}$ Biennial Report of the Directors and Superintendent of the West Virginia Hospital for the Insane for the Years 1875 and 1876 (Wheeling: John W. Gentry, Printer, 1876), 34.

${ }^{48}$ Annual Report, 1867, 10-11.

${ }^{49}$ Ibid., 12.

${ }^{50}$ Ibid.

${ }^{51}$ Ibid., 16.

${ }^{52}$ Ibid., 24.

${ }^{53}$ Ibid., 25.

${ }^{54}$ Ibid.

${ }^{55}$ Smith, History of Lewis County, 330-331.

${ }^{56}$ Sixth Annual Report of the Directors and Superintendent of the West Virginia Hospital for the Insane for the Year 1869 (Wheeling: John Frew, Printer, 1870), 5, 11.

${ }^{57}$ Smith, History of Lewis County, 330-331.

${ }^{58}$ Weston Democrat (Weston, WV), November 6, 1871, 3.

${ }^{59}$ Annual Report, 1870, 9.

${ }^{60}$ Smith, History of Lewis County, 330-331.

${ }^{61}$ Ibid., 331-332.

${ }^{62}$ Biennial Report of the Directors and Superintendent of the West Virginia Hospital for the Insane for the Years 1875 and 1876 (Wheeling: John W. Gentry, Printer, 1876), 5.

${ }^{63}$ Ibid., 34.

${ }^{64}$ Smith, History of Lewis County, 331-332.

${ }^{65}$ Biennial Report of the Directors and Superintendent of the West Virginia Hospital for the Insane for the Years 1879 and 1880 (Wheeling: W.J. Johnson Public Printers, 1881), 7.

${ }^{66}$ Ibid., 13.

${ }^{67}$ Smith, History of Lewis County, 332.

${ }^{68}$ Biennial Report, 1879 and 1880, 15.

${ }^{69}$ Smith, History of Lewis County, 332.

${ }^{70}$ Lawrence Chapman, History of Weston Hospital, Vol. 1 (Weston, WV: by the author, 1988), 16.

${ }^{71}$ Biennial Report, 1879 and 1880, 15.

${ }^{72}$ Smith, History of Lewis County, 332-334.

73 "The Asylum: Its Origin and Progress," Weston Democrat, November 13, 1871, 2.

${ }^{74}$ Biennial Report for 1875 and 1876, 36.

${ }^{75}$ Biennial Report, 1879 and 1880, 3.

${ }^{76}$ Carr, Weston Hospital, 4-5.

${ }^{77}$ Ibid., 7-8.

${ }^{78}$ Biennial Report, 1879 and 1880, 11.

${ }^{79}$ Rothman, Discovery of the Asylum, 111.

${ }^{80}$ Biennial Report, 1879 and 1880, 23-24. 
${ }^{81}$ Richard L Lael., Barbara Brazos, and Margot Ford McMillen. Evolution of a Missouri Asylum: Fulton State Hospital, 1851-2006. (Columbia, Missouri: University of Missouri Press, 2007), 66.

82 Ibid., 67.

${ }^{83}$ Biennial Report, 1879 and 1880, 23-24.

84 "Reasons for Admission," West Virginia Hospital for the Insane, list compiled from annual reports, 1864 to 1889 , contributed by Karl Staubly, substance abuse counselor at Weston State Hospital from 1971-1993.

${ }^{85}$ Biennial Report, 1879-1880, 22.

${ }^{86}$ Ibid., 16-17.

${ }^{87}$ Report of the Directors, Superintendent and Treasurer of the West Virginia Hospital for the Insane for the Years 1889 and 1890 (Charleston, WV: Moses W. Donnelly Public Printer, 1890), 48.

${ }^{88}$ William A. Marsh, ed., 1880 Census of West Virginia, Vol. 1: Lewis, Upshur, Taylor, Barbour (Parsons, WV: McClain Printing Company), 1979, 36-43.

${ }^{89}$ Chapman, History of Weston Hospital, Vol. 2, (Weston, WV: by the author, 1988), 11-12.

${ }^{90}$ Marsh, 1880 Census, 36-43.

${ }^{91}$ Rothman, Discovery of the Asylum, 146.

92 Ibid., 148-150.

${ }^{93}$ Lael, Missouri Asylum, 49.

${ }^{94}$ Zwelling, Shomer S., Quest for a Cure, 15.

${ }^{95}$ Ibid., 17.

${ }^{96}$ Lael, Missouri Asylum, 50.

${ }^{97}$ Ibid., 50.

${ }^{98}$ Rothman, Discovery of the Asylum, 237-240.

${ }^{99}$ Ibid., 266-267.

${ }^{100}$ Chapman, History of Weston Hospital, Vol.1, 40.

${ }^{101}$ Rothman, Discovery of the Asylum, 266-270. 


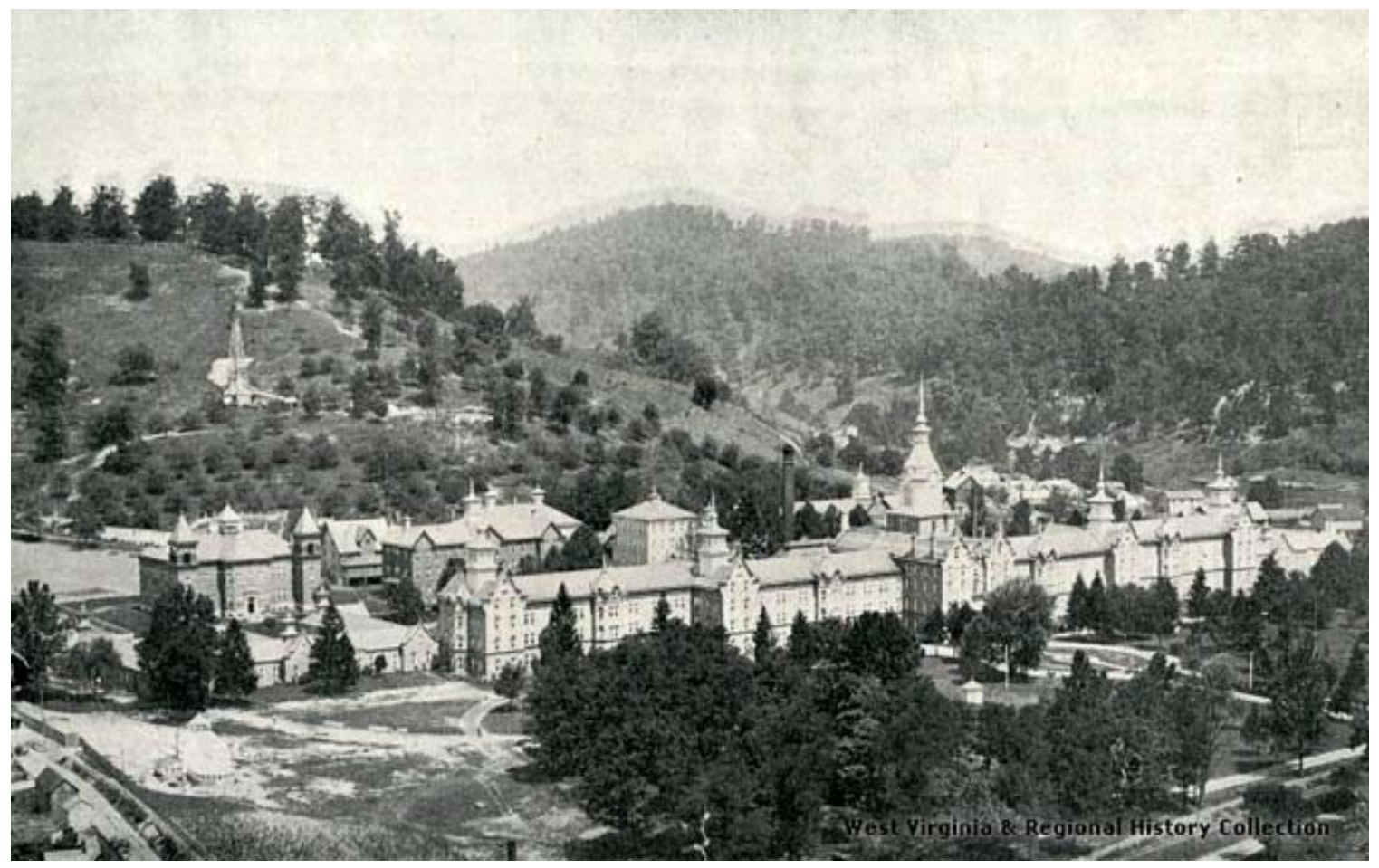

Weston State Hospital, after the 1902 gas well was drilled on the hill behind

West Virginia and Regional History Collection West Virginia University Libraries the hospital and before the 1930 addition of the general hospital building in the back left. 


\section{Chapter two 1900-1950}

\section{Weston State Hospital and institutional life}

Several changes were made in the early twentieth century at the hospital in Weston. In 1915 the legislature voted to change the name of the institution from the West Virginia Hospital for the Insane to Weston State Hospital. ${ }^{1}$ By this time there were other mental hospitals in the state. Spencer State Hospital and Huntington State Hospital were constructed in the 1890s, and then Colin Anderson Center for mentally retarded children would be established in 1921. Lakin State Hospital would be built for African American patients in 1926, and then Barboursville in 1942. The West Virginia Board of Control was created by the legislature in 1909 to supervise the state's educational, charitable, correctional, and mental institutions. ${ }^{2}$ Physical changes at Weston included the addition of a four-foot high Victorian wrought iron fence along the front length and northern side of the huge lawn, installed in $1892 .^{3}$ In the early 1900s, when natural gas prices were fluctuating, the hospital decided to drill its own gas well on the hospital farm. Gas was struck on February 2, 1902, and was immediately connected, resulting in a savings of $\$ 5000$ per year to the state. ${ }^{4}$

The early twentieth century was a time of population growth in state mental hospitals. A study done by the Council of State Governments in 1950 analyzed this growth and determined that there were several factors influencing this increase. There was general population growth, an aging

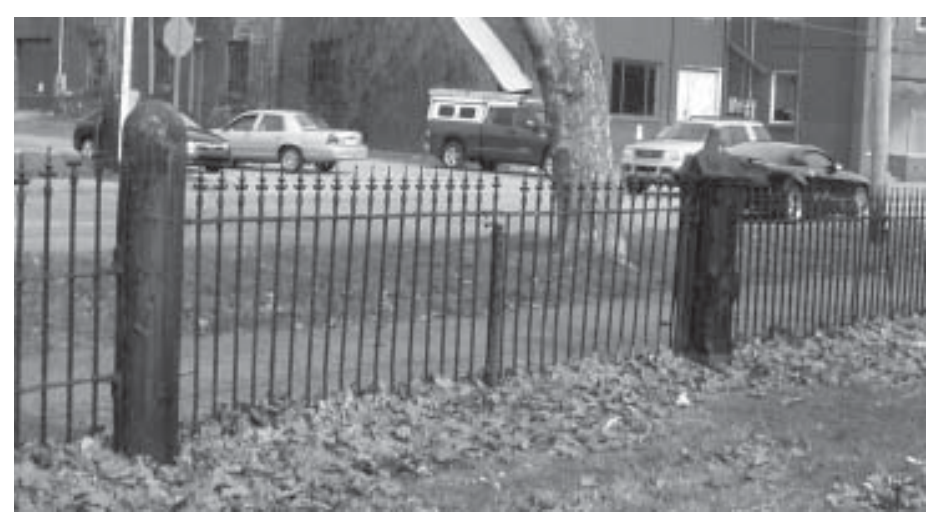

Gate in the wrought iron fence that was constructed in the 1890s. (Photo 2008) 
population, and a longer life expectancy, which resulted in longer hospital stays for the many elderly patients. Also, both physicians and the public had gained more knowledge about mental illness and were more willing to use these hospitals. In addition, the definition of mental illness had broadened, including more than just the most severe mental illnesses. Moreover, increased urbanization had led to less tolerance of deviant behavior. ${ }^{5}$ Historian Richard Lael noted that the increase in mental patient numbers was more than population growth, and historians still debate why. Perhaps a change in attitudes toward asylums by families, involving less stigma or fear of the institutions, or a lessening of obligation to care for the mentally ill at home contributed to rising patient admissions. Perhaps the move toward a more urban and industrial society made it more difficult to care for the mentally ill at home. Possibly society was using mental illness as an excuse to send away those who "deviated from the social norms of a community." As a result of education, perhaps more people recognized mental illnesses and had some faith in the medical profession's ability to cure it. Lael noted that Missouri's population increased by just over six percent between 1920 and 1930, and the population of the state asylums increased by 37 percent. $^{6}$

Danser Ford Company was contracted to drill six water wells for the hospital in 1903-04. Five of those yielded a "fairly good supply."

West Virginia and Regional History Collection West Virginia University Libraries

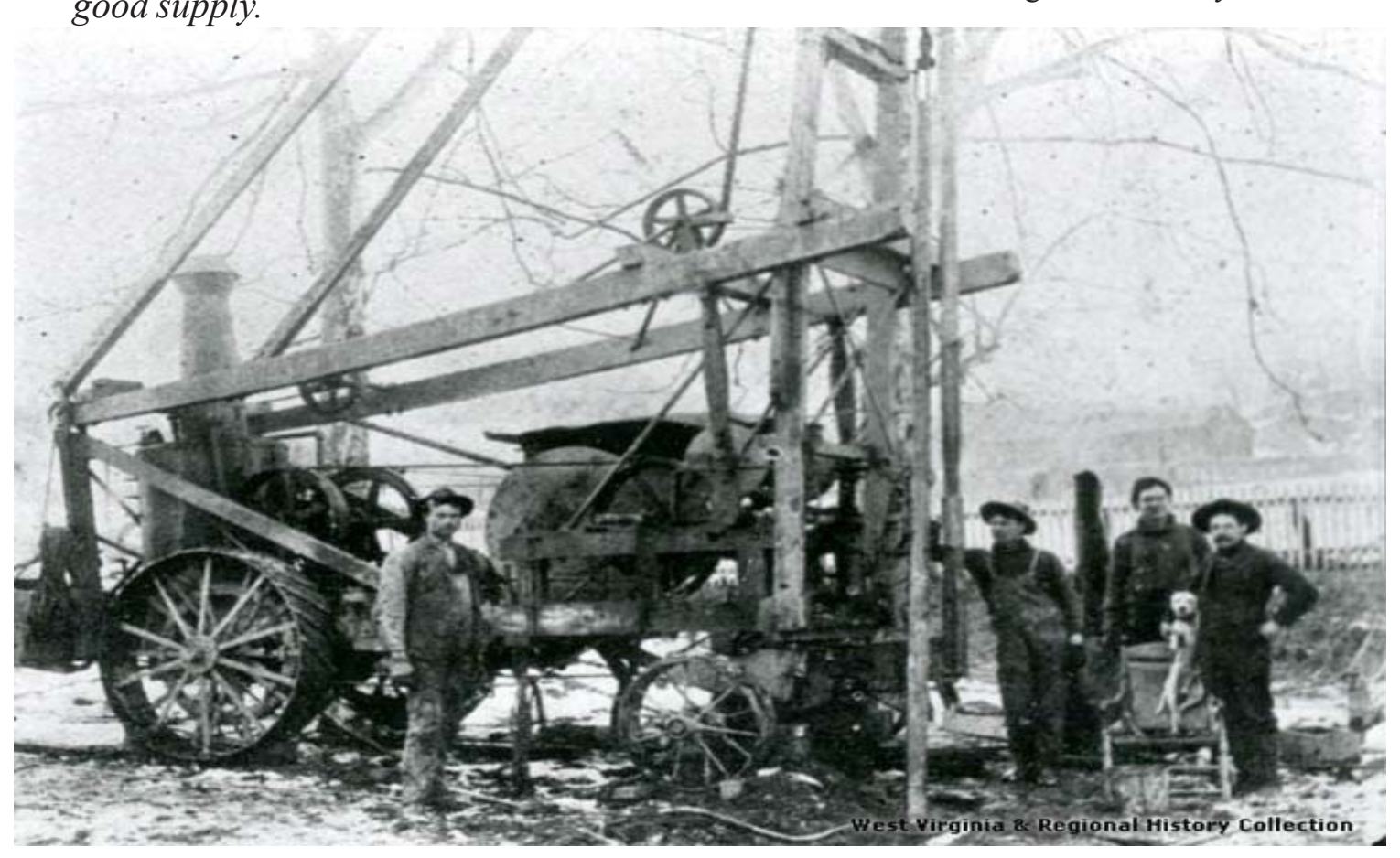




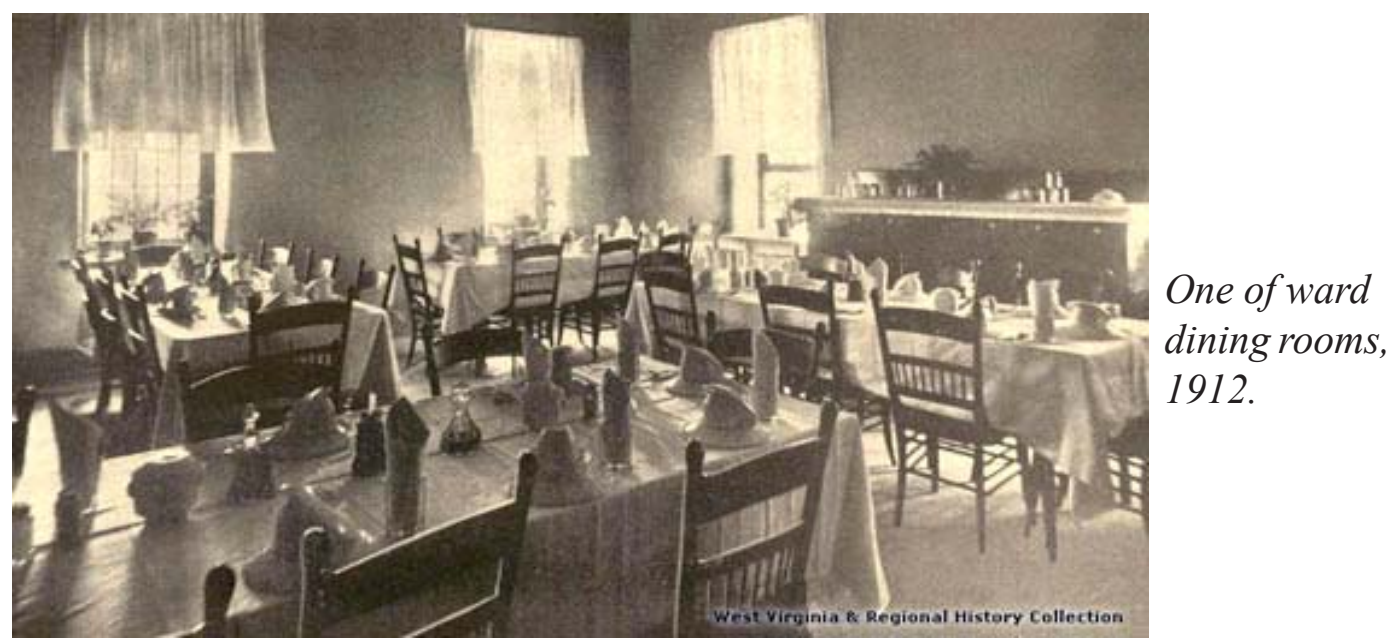

West Virginia and Regional History Collection

West Virginia University Libraries

Throughout its history, thousands of people have been employed at Weston State Hospital as doctors, nurses, attendants, cooks, maintenance workers, and housekeepers, among others. Some people spent their entire working careers as employees of the hospital. ${ }^{7}$ A 1907 booklet of employee rules and regulations for the hospital reveals some interesting facts about life in the hospital at that time. Most employees resided at the hospital. Attendants arose at 5:45 A.M. and opened the patients' rooms and got them ready for breakfast, then acted as waiters in the dining room and kept watch while the patients ate. They had to collect all the knives and other cutlery and count them before the patients left the dining room. Attendants were to clean up the wards and control the patients, without use of profanity or violence, except "in the clearest case of self-defense." Mechanical restraints or isolation could be used only with a physician's approval. Attendants were to keep the patients clean, change their bedding weekly, and make sure they bathed. One attendant was to be in the hall with the patients at all times. They were also to provide amusement and entertainment for patients and supervise at dances, church services, and other activities. Employees were to engage in card playing only during their time off or if "for the benefit of the patients." Employees retired to their rooms at 10:00 P.M., unless given special permission to be out until 11:30 P.M. ${ }^{8}$ The attendants' duties were extensive considering the meager pay they received, and living at the hospital, though a financial help, might have been wearing on the employees.

Other employees whose duties were described were engineers, carpenters, a farmer who supervised the farm laborers, bakers, a painter and a plasterer, and a florist in charge of the greenhouse, lawns, and flowerbeds. There was also a tinner to make and repair 
tinware, inspect gutters, fix leaks, and repair iron bedsteads. An upholsterer cared for the main hall and laid carpets. A seamstress was in charge of the patients in the sewing room who made clothing for the patients, sheets, and other articles. ${ }^{9}$ An assistant matron's report from 1889 relates the production of the sewing department for that year. Among the forty items listed were 412 pairs of pants, 172 suits, and hundreds of dresses, aprons, and drawers. They even knitted 411 pairs of
REPORT OF SUPERVISOR OF CUTTING AND SEWING ROOMS. From October 1,1904 to September $30,1905$.

To Dr, A. H. Kunst, Superintendent of the Weat Virginia Hospital for the Insone, Weaton, West Virginia:

Deas BIs:-I berewith submit to you a report of the Cutting and Sewing Fooms for the year commencing October 1, 1904 and ending Beptember 30,1905 .

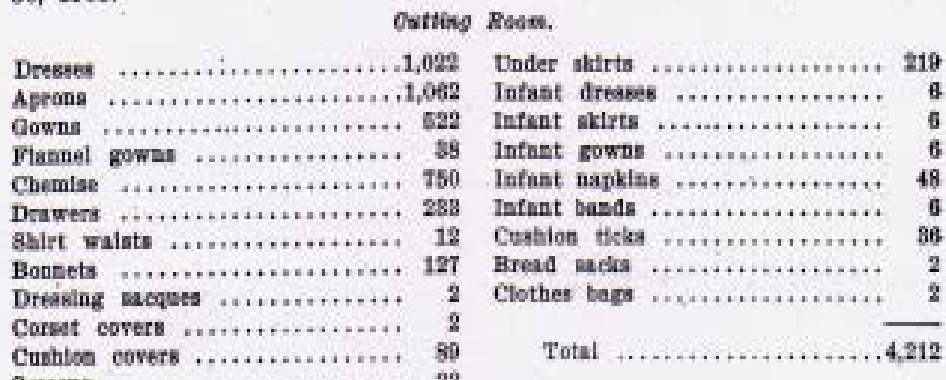

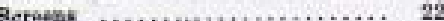

Irade in Bescing Room.

\begin{tabular}{|c|c|}
\hline beets , & ter \\
\hline$\ldots \ldots \ldots \ldots \ldots 1,090$ & Mangle corers ... \\
\hline els $\ldots . . . \ldots$. & Aprons $\ldots \ldots \ldots+\ldots \ldots+\ldots \ldots \ldots$ \\
\hline 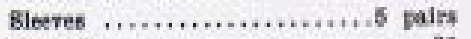 & C. B. PIllow easea , .............. \\
\hline ads ...................... & Cover for frust Jars .. \\
\hline I chemise,$\ldots \ldots \ldots+\ldots \ldots$. & Bags , f............... \\
\hline sadrts,$\ldots+\ldots \ldots \ldots \ldots \ldots$ & Binds .... \\
\hline pHllows $+\ldots \ldots \ldots \ldots \ldots \ldots$. & Bread hage \\
\hline ase ticks pdeced ,........... & Coats repa \\
\hline se theks $\ldots \ldots \ldots \ldots \ldots \ldots \ldots \ldots, 166$ & Bbe: \\
\hline Dader shtrts , ...,...., ........ & ets for engtne $\ldots . . . . . . . . .$. \\
\hline Ualen sulta ... & Awafogs ....................... \\
\hline able linen $\ldots . ., \ldots \ldots \ldots \ldots$ & Cashices : \\
\hline low cases , .................. 1,05s & 8cresns .. \\
\hline ers ........................ $17 \mathrm{z}$ & Orerall sults $\ldots \ldots \ldots \ldots \ldots \ldots \ldots$ \\
\hline ants repaired $\ldots \ldots \ldots \ldots \ldots \ldots, 28$ & made in Sewting froom. \\
\hline
\end{tabular}

Note the items for infants. Public Documents of West Virginia West Virginia and Regional History Collection West Virginia University Libraries mittens and made 34 shrouds. Some insight into why this hospital was one of the least expensively run hospitals in America is revealed in the fact that the sewing room reported 40,241 articles mended that year. There was little waste. ${ }^{10}$

An interview published in a Weston newspaper in 1934 with a hospital employee, Mary Ryan, who had worked there for fifty-two years, presents more of a picture of the institution. She remembered how in earlier days (she began work there in 1882), there were two or three "artificial gas lights" to illuminate each ward, and attendants had to use candles, made by the hospital cook, to check on the patients. Over the years, Ryan worked as a cook, a maid, and an attendant in six different wards. She recalled the use of sleeves, straps, and cribs to restrain patients. She said that when Dr. Crumpbacker, an Ohio psy- 
chiatrist, became superintendent in 1893, he abolished these modes of restraint. He instructed attendants to sit with a violent person and restrain him. Ryan's most recent assignment had been to care for thirty-eight elderly women. Most of them had been cured of their mental disorders, but had been at the hospital so long they had no family to whom they could return. ${ }^{11}$

A 1927 investigation into the death of a patient at Weston State Hospital conveys more information about the institution in the 1920s. Hearings were held regarding the death of a 38-year-old woman, a Mrs. Hoffman of Fairmont, who had been at the hospital for only 48 hours. She had been held in restraints much of that time, and her body showed bruises to the shoulders, arms, back, and lower limbs, so her family questioned her treatment at the hospital. Before entering the hospital, Mrs. Hoffman had been exhibiting strange behavior, her first ever mental disturbance, for about a week. She had been suffering for some time from a goiter in her neck, and while at a religious service had been told by her minister that God would heal her. After the service she began to behave strangely, thinking she was the Virgin Mary, and that her doctor was God. She was not eating, but spending a lot of time singing loudly. The family first took her to the hospital in Fairmont where she was given five or six morphine injections one day and then two again the next morning before they transported her to Weston. She was very ill in the car, probably due to the morphine, and then became violent with the attendants at Weston who were trying

\section{Female ward, main building.}

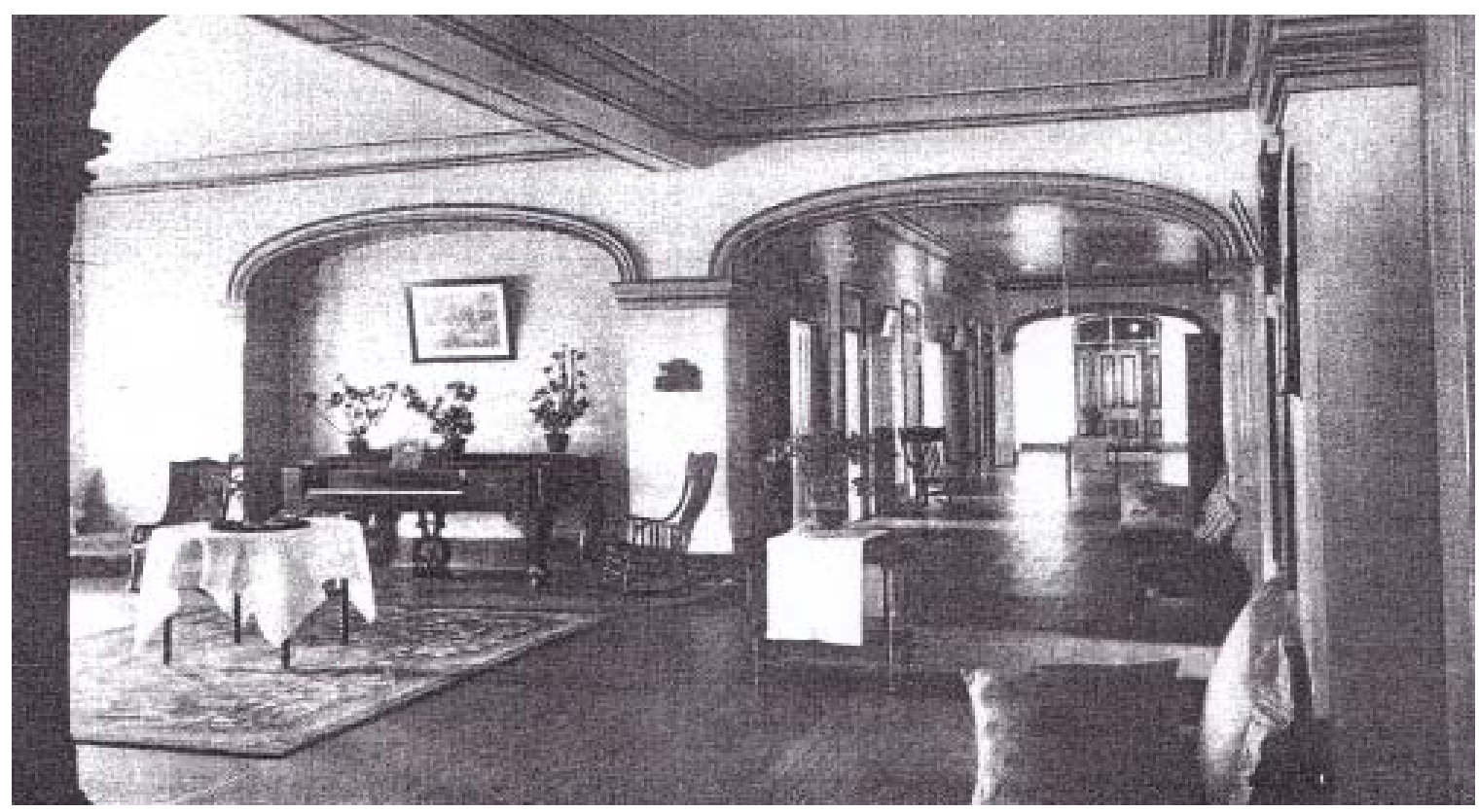




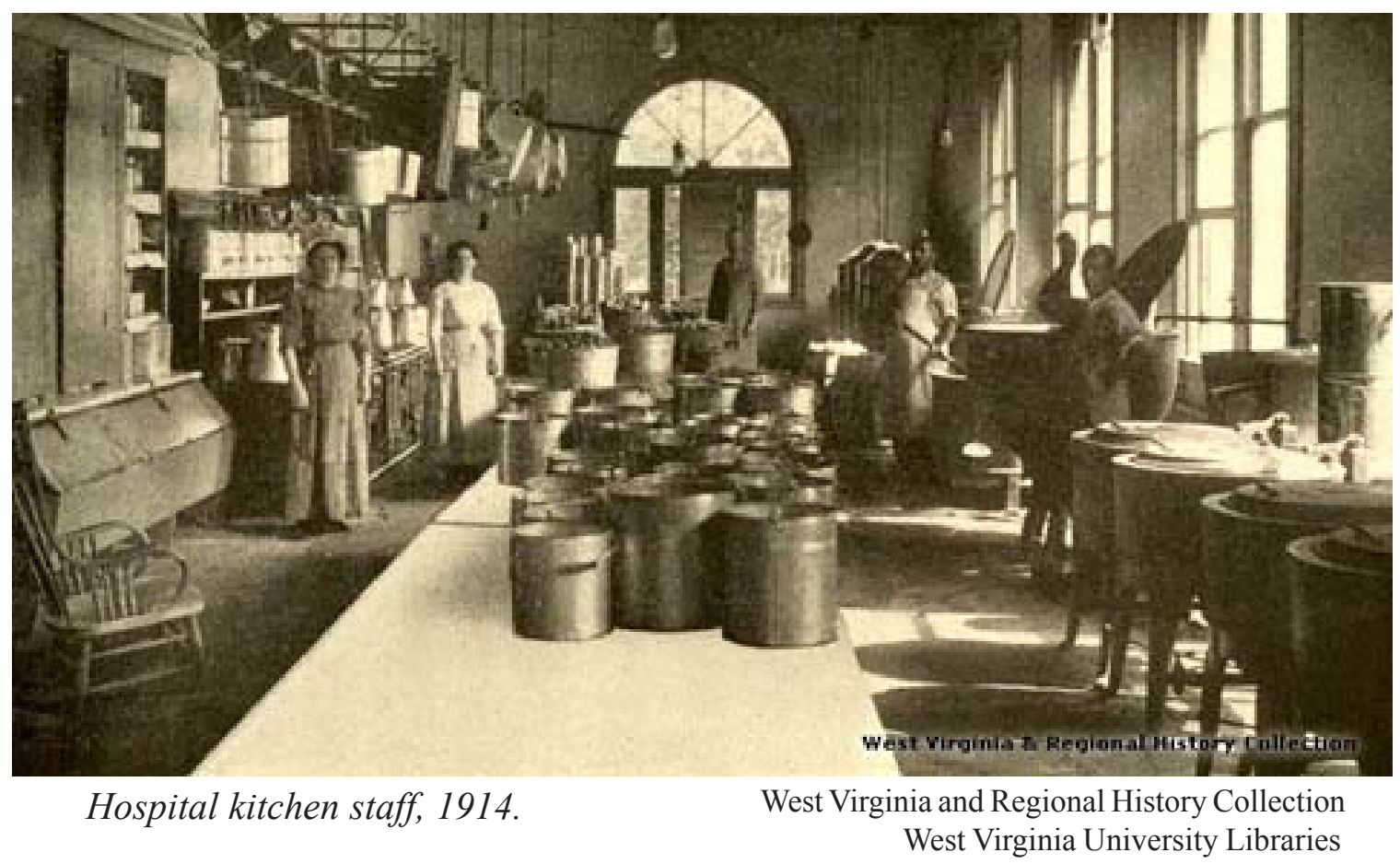

to change her clothing. They put her in sleeves, which allowed her to move her arms and hands only one foot in each direction. Stockings were tied around each ankle, with another tied between her feet and tied to the foot of the bed. These prevented violent movement, such as kicking the attendants, but supposedly did not cause cramping. A draw sheet, folded in half across her abdomen, was brought down and wrapped around the side rail of the bed.

Several people testified at the hearing. It was revealed that there were only three physicians for the 1300 patients, and the doctor explained he had looked at Mrs. Hoffman but not prescribed any treatment. Three attendants were responsible for sixty-five patients, which is why someone like Mrs. Hoffman was restrained, as other similar patients commonly were. Her sister testified that she had visited her, and that Mrs. Hoffman had begged not to be tied down, and had said she would die if she were not untied. Attendants testified that Mrs. Hoffman was not restrained the entire time, but that she was released for eight or nine hours. Testifying at the hearing, the hospital superintendent, Dr. J.G. Pettit, explained that restraints were necessary to prevent injury to the patient and for the protection of the attendants. He believed that the use of morphine was bad for the treatment of acute psychotic conditions, and he did not use it. He described various treatments used to control "excitable patients," including the continuous bath, which involved submerging a person from the neck down for up to ten hours. Wet packs and dry packs 
were also used. Wet packs involved laying a naked person on three blankets wrung out of cold water, and wrapped and bound around the patient from the neck down. They were left for one-half to two hours and generally with a cold pack on their head. A dry pack had the person's body being enveloped in dry blankets for one to three hours. Dr. Pettit was not convinced of the effectiveness of any of these methods, though he had used the continuous bath and wet pack at times. He thought the dry pack would be awful, allowing no freedom of movement of the ankles or elbows or hands.

After testimony from attendants who described how they had bound Mrs. Hoffman's hands and legs after she was found dead in order to keep her in a natural position before being sent to the funeral home, and testimony from the undertakers who cared for her, the conclusion was that Mrs. Hoffman had not been mistreated at the hospital. Her restraints were standard procedure and may not have been the cause the bruising. The morphine injections may have affected her heart. Mrs. Hoffman had been a thirty-eight year old wife and mother, with no previous psychotic episodes, described by some of the aides as noisy but not violent, who within a few days had died under mental health treatment. It was decided that the hospital and superintendent were not guilty of neglect or acts contributing to her death. ${ }^{12}$

Nurses, 1916.

West Virginia and Regional History Collection

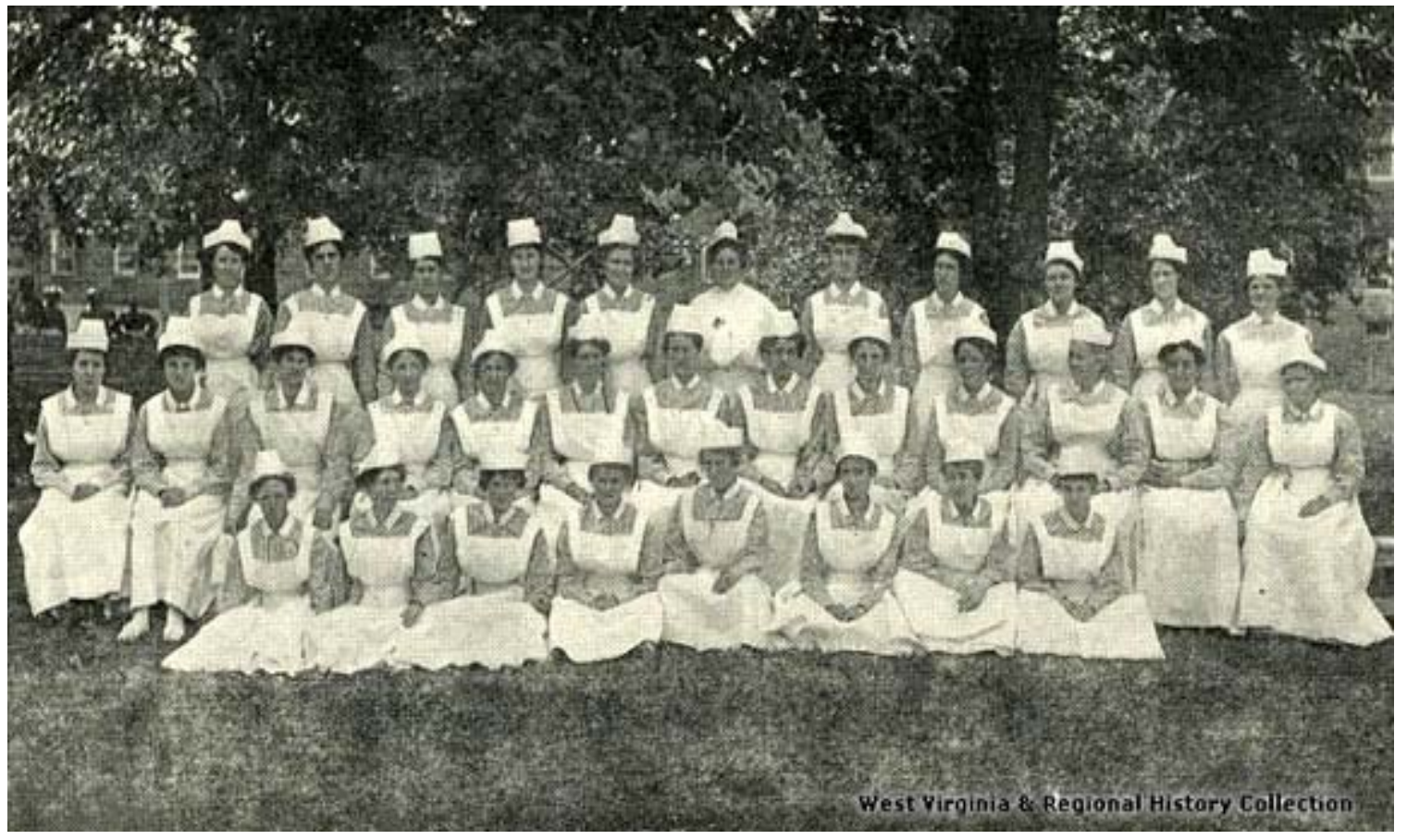


Hydrotherapy, mentioned in these hearings, was widely used in the first half of the twentieth century as a treatment for the mentally disturbed. The continuous bath involved placing a disruptive patient in a hammock suspended in a bathtub with a canvas sheet secured across the top and only the head emerging above. Patients might remain in the tub for hours or even days, sometimes with bandages around their eyes and ears, and sometimes with ice caps on their heads. Doctors believed that the bath induced fatigue without hurting the mind and "stimulated excretory function of the skin and kidneys." A "needle shower" was essentially pummeling the patient with pressurized water; the water pressure was up to forty pounds, as cool as $50^{\circ}$, and lasted a minute or two. This was purported to stimulate the heart and blood and was to help the depressed patient. One physician admitted, "We meet with more or less opposition on the part of the patient to the administra-

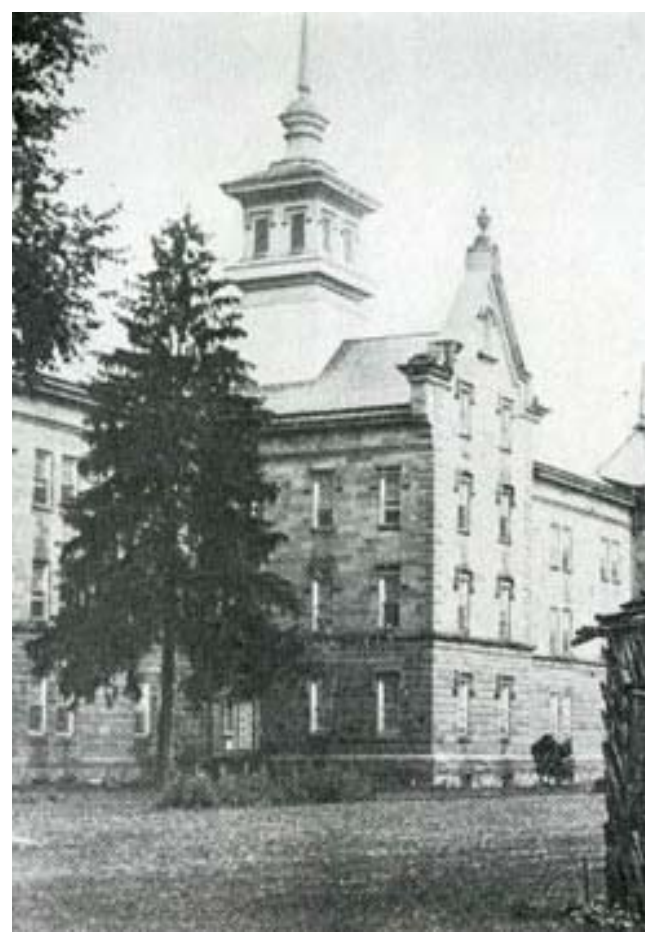

One of six summer houses.

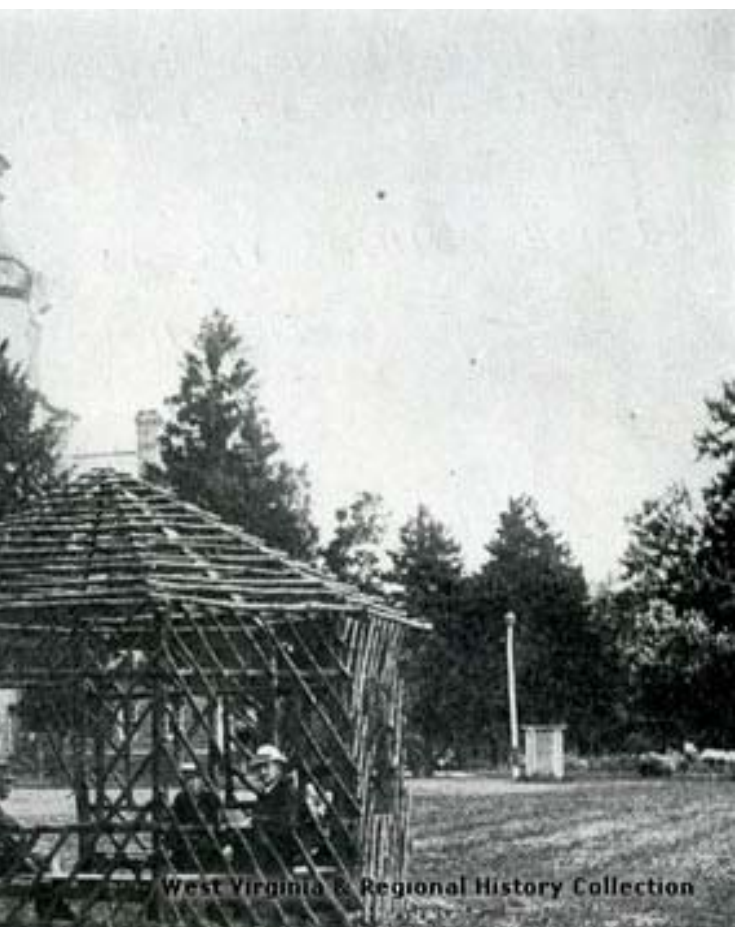

West Virginia and Regional History Collection West Virginia University Libraries

tion of these baths." ${ }^{13}$ The wet pack required dipping sheets or blankets in cold or warm water and wrapping them tightly around the patient so they could only move their head, fingers, and toes. Sometimes they were left for hours or even a day or two. As the sheets dried they would shrink tightly around the patient and make them retain body heat, feeling as though they were burning or suffocating. Doctors considered the wet pack a beneficial treatment for restlessness. ${ }^{14}$ 


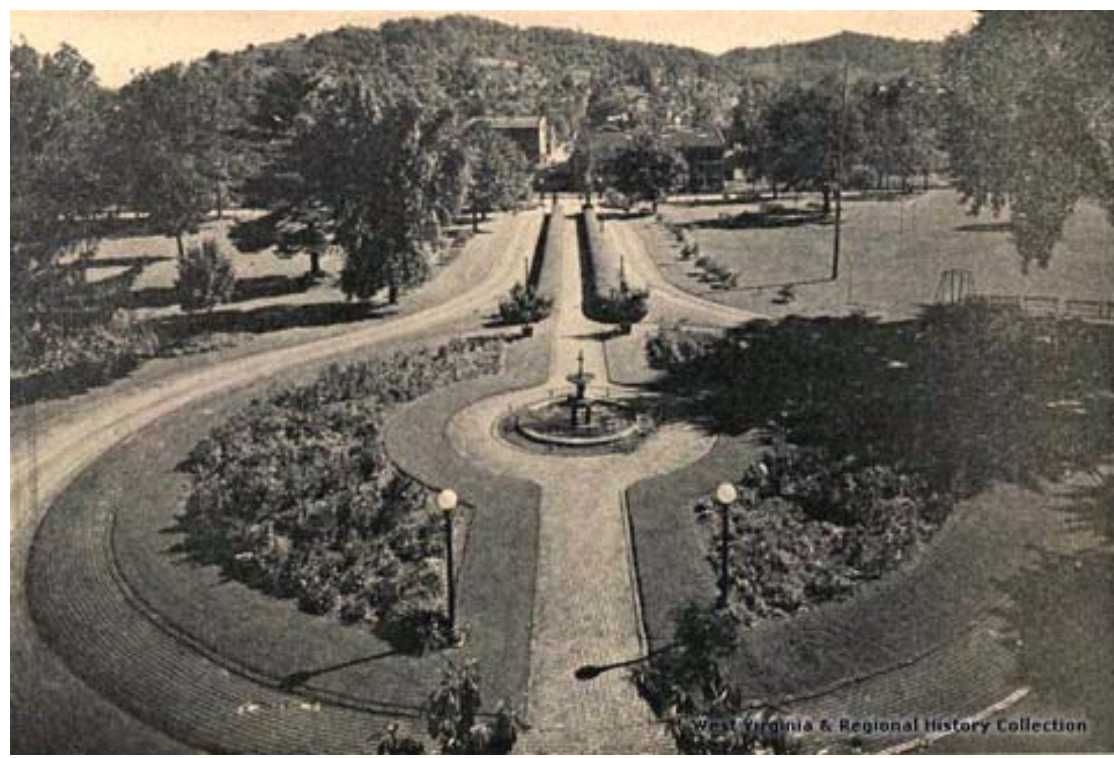

Front lawn, 1924.

West Virginia and Regional History Collection West Virginia University Libraries

Reading about some of the therapies used at mental institutions makes it not too surprising that some of the patients might want to burn the place to the ground. The entire main building at Weston was almost destroyed by fire on October 3, 1935. The fire began at about 10 A.M. Later, an 18-year-old male patient admitted to starting the fire. He confessed he had started a little fire with some papers on the unoccupied fourth floor of the south wing and then had become frightened and "ran out to the hogpen." 15 Six wards were destroyed by fire and water. The slate roof was destroyed and a cupola collapsed and fell through the roof as firefighters from the Weston Volunteer Fire Department fought the blaze. However there was no loss of life since the patients were quickly removed from the building by the attendants. ${ }^{16}$ Later it was rumored that the staff had rung the dinner bell to urge the patients to exit in an orderly manner, but though that had been suggested, it was not necessary since the attendants evacuated everyone quickly. Fire departments from Buckhannon, Clarksburg, Elkins, Grafton, Shinston, Parsons, Glenville, and Salem helped fight the fire. ${ }^{17}$ One young patient was seen at a fourth floor window, trapped by the flames. ${ }^{18}$ Quickly, two firemen raised a fifty-five foot wooden ladder up to the window. Normally about eight men were used in lifting this ladder. Fire Chief Gary Marsh went up the ladder to rescue the man, and the man inside grasped the bars on the window and bent two of them enough to allow himself room to escape. Marsh then helped the man to the ground. ${ }^{19}$ Great clouds of smoke filled the sky, and many Weston residents gathered to watch. The fire seriously threatened the entire building until noon. It was finally extinguished by 2:00 P.M. ${ }^{20}$ 
Wild rumors circulated throughout the state that day. Early reports by telephone and radio had said that the whole building was burning, and that patients had burned to death. Some reports said that mental patients had escaped and were roaming throughout central West Virginia. ${ }^{21}$ Phone calls were coming in from all over the state from families concerned over their relatives' safety. The evacuation of the burning building actually went quite smoothly and calmly. Members of Company E of the $201^{\text {st }}$ National Guard and the state police were called to guard the patients and keep the crowds away. The rest of the hospital continued to run smoothly — the kitchens, dining room, sewing room, and other buildings. ${ }^{22}$ Over 300 patients were transported to Jackson's Mill, a nearby 4-H camp, by streetcars and school buses and were housed in the cottages there for a few weeks. The National Guard members acted as guards at the cottages to prevent escapes. Ross White was a member of this National Guard unit and recalled these events. He remembered with a laugh that one of the guardsmen who was helping transport the patients to Jackson's Mill on the streetcar was mistaken as a patient by some of the police. He had to argue with them to prove he was not a mental patient. Mr. White also described serving a shift as a guard at Jackson's Mill for several weeks. He and another man stood at opposite corners of the yard of one of the cottages to make sure that no patients escaped. ${ }^{23}$ The state requested federal government help for rebuilding the hospital; President Roosevelt an-

Patients and nurses, Ward B, 1924.

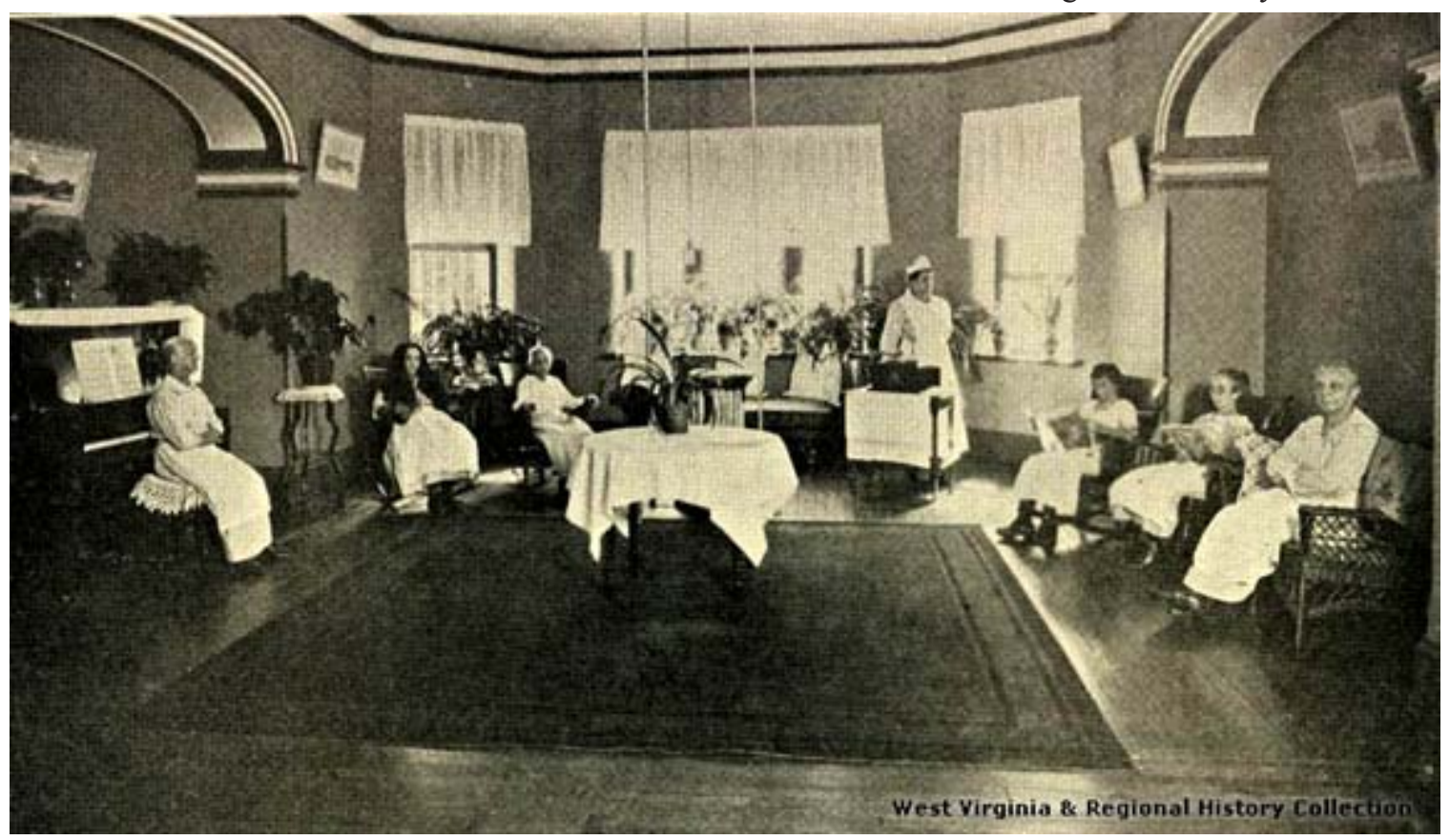




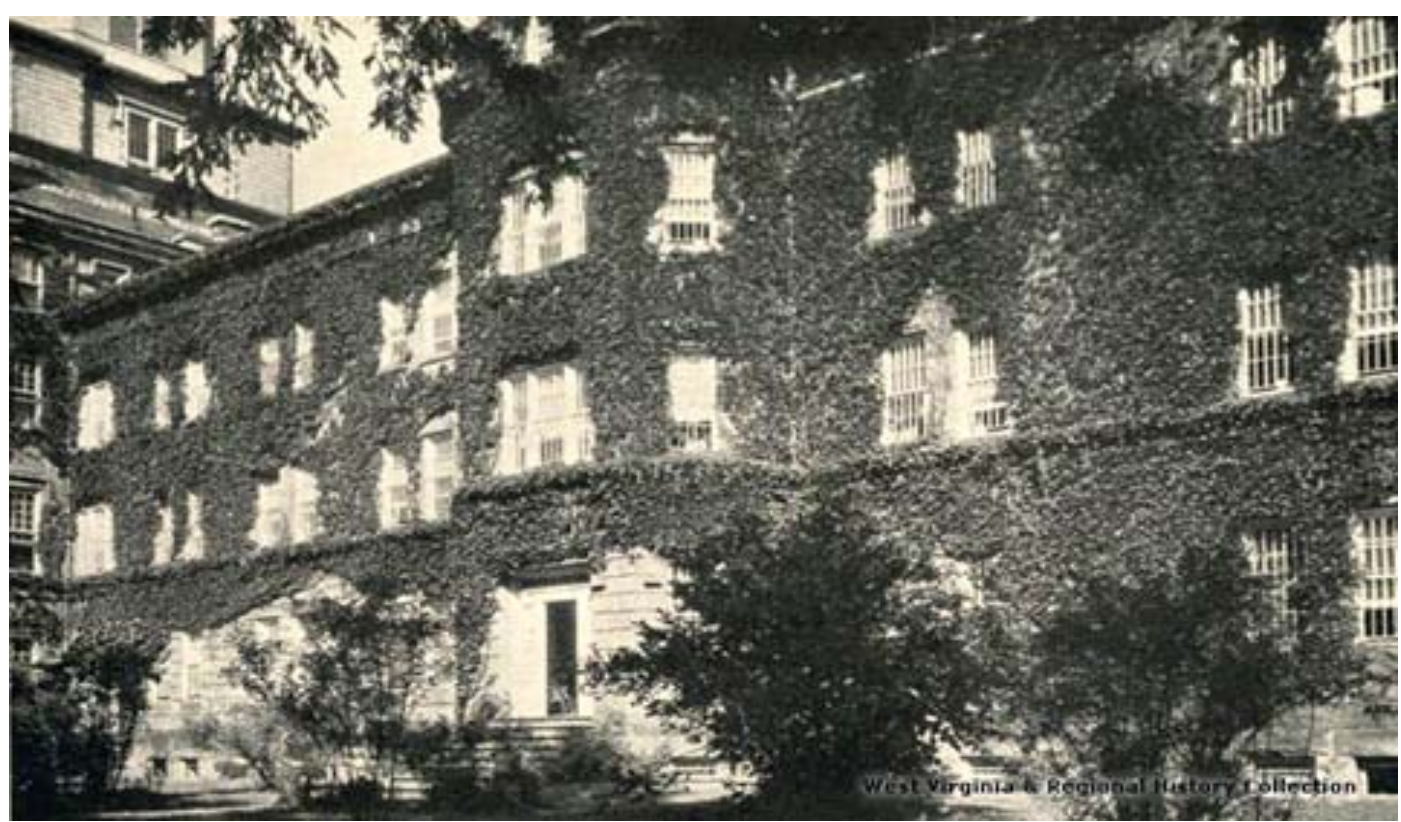

Female ward, 1930.

West Virginia and Regional History Collection

West Virginia University Libraries

nounced a $\$ 115,000$ Works Progress Administration allotment for reconstruction costs. ${ }^{24}$ No insurance had been carried on the building, though the hospital had experienced a few small fires in the preceding months. ${ }^{25}$ The building was repaired, and all the patients moved back to the hospital within a few months.

The Weston State Hospital building and grounds were also used by the community throughout its history. The large ballroom in the central administrative section was used for cotillions, chautauquas and other events. The local populace picnicked on the hospital lawn. In the first half of the twentieth century, the Weston High School football team held its games on the hospital lawn. ${ }^{26}$ Ross White, who played on the high school team in the 1930s, recalled how there was a tree in the corner of one endzone of the field. The team repeatedly requested that the tree be cut down, but the hospital refused. Every time the ball got near that corner of the field, the referee would move it over to the other side to avoid accidents. Opposing teams swore that the Weston team built plays around that tree. ${ }^{27} \mathrm{~A}$ few of the patients took advantage of the football activities at the hospital. One enterprising patient secured a town pass, got a big two-wheeled cart, hired a strong patient to pull it, and went across the river to the ice plant. He filled the cart with ice, went to the grocery store and purchased Coca-Cola for five cents a bottle, and brought it to the football games to sell at twenty-five cents a bottle to the spectators. Because there were no 
bleachers, the fans stood close to the field, and he had to stay on the field to sell his drinks. When officials tried to run him off, he stumped them by replying, "You can't run me off this field. I live here and this is my front yard." ${ }^{28}$ Ross's cousin, Jimmy Means, recalled a patient named Teddy [perhaps the same man] who had a wagon and sold candy at the football games. Jimmy remembered that one time Teddy had red marks on his face. When they asked him what the marks were from, he told them that he had tried to take food from another patient's plate and that the patient had stabbed him with a fork. ${ }^{29}$

\section{Deteriorating conditions and new treatments: Shock therapy, lobotomies, and antipsychotic medications}

By the 1940s and 1950s treatment for the mentally ill was changing dramatically. The introduction of new therapies and new anti-psychotic drugs brought both promise and tragedy, and the initial stages of a move toward deinstitutionalization. The Sixteenth Report of the West Virginia Board of Control 1948-1951 to the West Virginia governor provides a picture of the situation at Weston State Hospital at this time. Although the hospital had a rated capacity of 1,250, it housed 2,007 patients, while many remained on waiting lists, held in jails..$^{30}$ Scott Finn, in reviewing the history of Weston State Hospital for the Charleston Gazette, noted that many of the patients had disorders such as schizophrenia and bipolar disorder (manic depression). A large number of patients suffered from mental retardation, and many from alcoholism and drug addiction. Over the years, Finn stated, the hospital served as "a dumping ground for unwanted people. The fact that the state legislatures did not allocate enough funds to adequately care for the patients in the overcrowded facility resulted in tragic neglect of the most unfortunate citizens in West Virginia."31

One of the biggest problems facing the institution in 1950 was the high turnover rate among male attendants employed on the wards. Their low salaries could not compete with those at the veterans' hospitals and defense plants. The hospital had recently, in 1948, adopted an 8-hour workday, reduced from the previous 12-hour day. ${ }^{32}$ Until 1948, the attendants, cooks, and waitresses had worked from 6:30 A.M. to 6:30 P.M. with one day off each week or two, and for very little pay. It was important for attendants to the mentally ill to be alert and wakeful, so the reduction to eight-hour shifts was meant to improve their efficiency and provide better patient care..$^{33}$ Improved hours might also help with employee retention. 
According to the 1951 Report, Weston State Hospital was still producing much of its own food. The farm acreage of 532 acres supported 133 dairy cows and heifers, five bulls, 35 sows, and two boars, providing nearly all the milk and pork for the hospital's needs. A large quantity of corn, hay, and

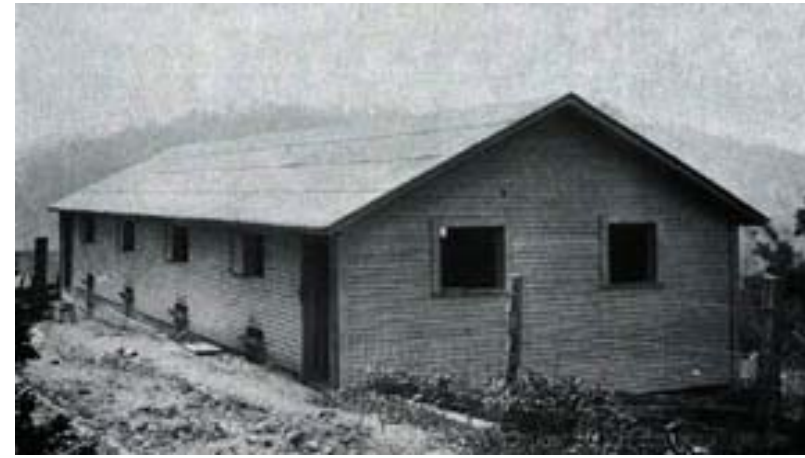
Hog fattening pen.
West Virginia and Regional History Collection, West Virginia University Libraries soybeans were grown on the property, and there was a sizeable pasture. A large natural storage building had been recently erected for storing fruits and vegetables. The stone had been quarried on the hospital grounds, and the building had a capacity of four freight carloads. It was mostly covered with earth to maintain even temperatures. A small coal mine was still worked on the hospital grounds. A mine superintendent and eight miners produced 12,000 tons per year, used for heating. ${ }^{34}$ The report also noted that some new cottages had been built for the physicians in order to make more room in the main building for other personnel. ${ }^{35}$ In a letter dated August 16, 1943, from the hospital superintendent, Henry Garrison, to the to the Board of Control, the superintendent said the hospital was delivering loads of coal to attendants who lived within a mile of the hospital in lieu of giving them a raise, which the hospital could not afford. ${ }^{36}$

The Board of Control Report of 1948-1951 described a new hydrotherapy department. Over twelve hundred patients had received 4,404 continuous baths, averaging almost seven hours each time. Only twelve had received wet sheet pack treatments, with an average time of five hours each. Over 2,000 received treatments of "stimulating hydro" such as steam baths, rubs, and needle showers. Occupational therapy was being provided for a few patients, with a new arts and crafts section with rug and mat making, weaving, and a woodworking shop. In 1950 about 800 patients had spent 1,258 hours there and made many saleable products. (That translates to less than two hours per participating patient on average for the year.) Entertainment provided for the patients included, in a one year period, 134 dances, including one big dance with an outside orchestra per month, 129 movies, 32 bingo parties, and 63 chapel services. In winter, a recreation room provided cards, pingpong, and shuffleboard. In summer, a men's softball team was formed, and the women 


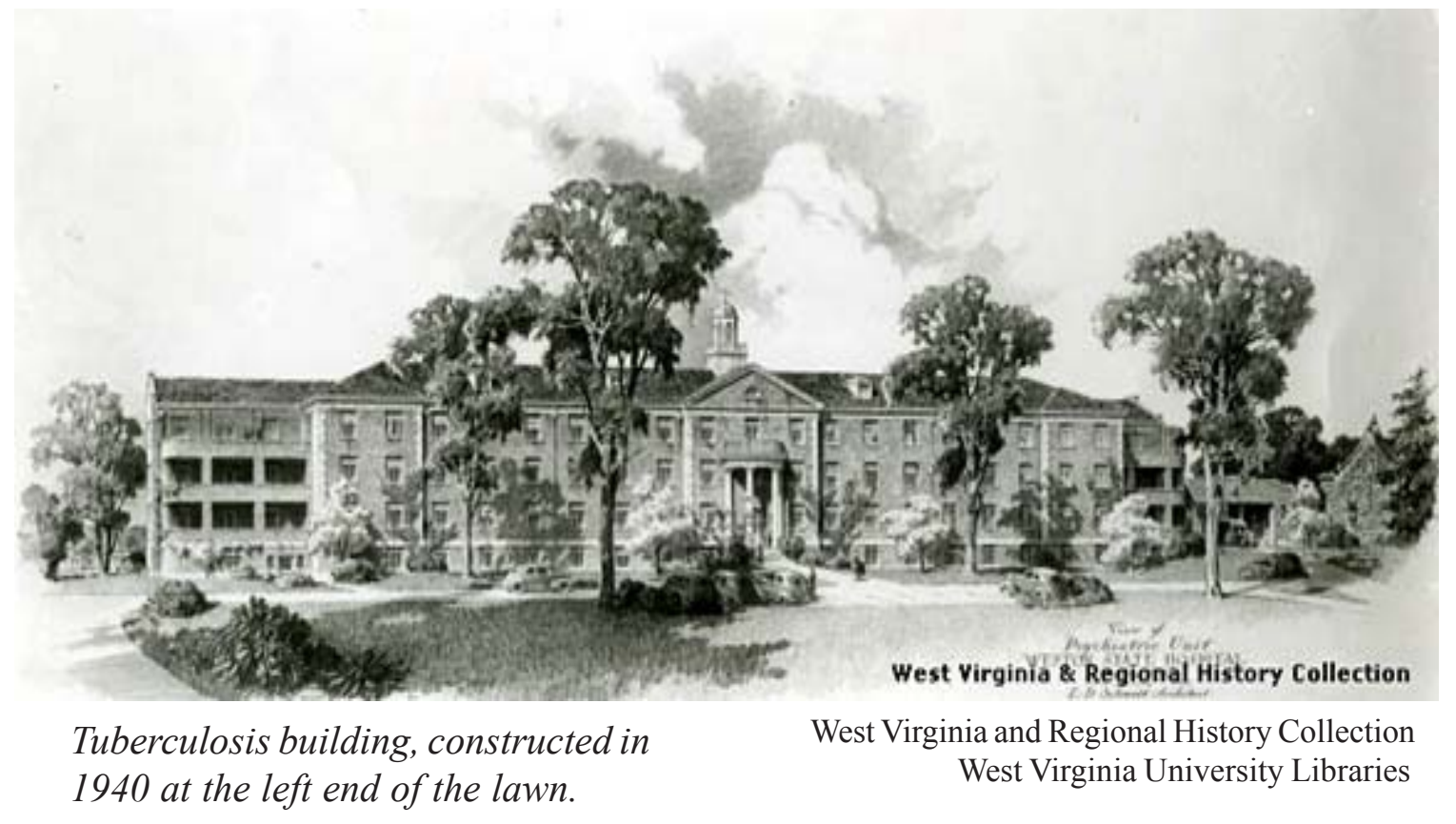

could play badminton, volleyball or croquet on the lawn. ${ }^{37}$ No numbers were given as to how many patients participated in these activities.

In addition to hydrotherapy and occupational therapy, reported treatments being used were psychotherapy, electroshock therapy, and "work in the hospital." A psychology department had been established in 1950, with one psychologist who had examined 147 people. Electroshock was used daily, with thousands of treatments given, and only one person with cardiac problems was reported as having died from the procedure. Most patients being treated received shock treatments three times a week. It was noted that not enough staff was available at Weston to follow up the treatments with half-hour interviews as was recommended. ${ }^{38}$

Electroshock therapy had been introduced in American hospitals in 1940, touted to be a cheaper and more effective way to induce convulsions in a patient than the previously used insulin and metrazol. Insulin, metrazol, and electroshock therapy all dimmed brain function. With electroshock therapy, electrodes were placed at the temples and a jolt of electricity passed through the temporal lobes, resulting in convulsions. Patients awoke dazed, sometimes not knowing who they were, and often ill with headaches and nausea. Intellectual function and memory were impaired, and patients were fatigued and remained passive. The patients seemed to lose the "higher cognitive processes and emotions that caused fantasies, delusions, and paranoia." 39 Schizophrenic symptoms declined with electroshock, but so did overall mental functioning and memory. The "curing" power of 
electroshock was only temporary and psychotic symptoms often returned, so many patients were treated repeatedly, even daily. Some of these eventually suffered serious brain damage and had no hope of recovery. The treatments were also extremely painful. Until they began the use of paralyzing drugs before the procedure, forty percent of patients suffered bone fractures from wild thrashing during the convulsions. After experiencing shocks a few times, many patients made wild attempts to escape when facing further treatments. Many would tremble and sweat and beg for help. Patients reported to their doctors that electroshock was "like having a bomb fall on you" or "being in a fire and getting all burned up." ${ }^{\prime 0}$ The belief among physicians was that electroshock made psychotic symptoms and depression disappear, even if it hindered the patient's ability to think and remember for a time. Physicians felt they had a right to administer it even to unwilling patients. It remained a common procedure for two decades. Hospitals found it useful to help quiet the wards, a sedative for disturbed patients. ${ }^{41}$

According to the Board of Control report, another new treatment had been recently introduced. Seventy transorbital lobotomies had been performed at Weston with "a definite benefit to one-third of these and no ill effects" cal disabling" of the prefrontal lobes of the brain, were introduced in the 1930s and begun in the United States in 1936 with the first surgery performed by Dr. Walter Freeman and Dr. James Watt. Freeman later performed many lobotomies at Weston State Hospital and other hospitals in the state. These surgeons and others proclaimed great successes, claiming that lobotomies could relieve depression, anxiety, delusions, panic states, suicidal thoughts, and other mental disturbances. They also claimed that there were no detrimental effects; if there was no improvement in a patient, then there was no damage either. In a 1950 book entitled Psychosurgery, Freeman and Watts reported that eighty percent of the 623 patients they had lobotomized had been helped. They went on to describe what families should expect when the lobotomized patient returned home. In the first weeks they would often be incontinent and would not want to get out of bed. Sometimes nurses had to turn patients to keep them from getting bedsores. The patient would often show no interest or distress, but have a blank mind, and was often very childlike. About twenty-five percent of patients never progressed further than this in recovery and remained hospitalized. Patients who had been disruptive on the wards of a hospital were usually better behaved. If they came out of their lethargic state and were too restless, electroshock could be administered. Sometimes the surgery was repeated. Patients who 
remained quiet and not disruptive were considered as having a good outcome. Most patients were able to return home. Freeman and Watts reported that about twenty-five percent of the patients who returned home could be "considered as adjusting at the level of a domestic invalid or household pet." ${ }^{43}$ The best outcomes were patients who were able to resume employment and a fairly normal life. However, even they could not be expected to handle multiple tasks or be able to plan ahead.

Freeman and Watts determined that the frontal lobes of the brain give a person a consciousness of self, an ability to love, a sense of creativity, and spirituality. This center of higher mental activity was the area that troubled the mentally ill, therefore disconnecting it with a lobotomy allowed the patients to stop worrying about their responsibilities or the past or the future. The success of lobotomies was quite exaggerated, by both those who performed them and by the press. Whitaker suggests in Mad in America that this was partly the result of physicians wanting to further their opportunities to perform brain surgeries and thereby earn income, and also to ensure continued money from sources such as the Rockefeller Foundation. Dr. Freeman began using a simplified method of performing the surgery, known as the transorbital lobotomy. The first surgeries, prefrontal lobotomies, had involved drilling holes in the front or side of the skull and either inserting alcohol to kill tissue through dehydration or cutting nerve fibers. Drilling holes through the skull was very time consuming. So Freeman adopted the transorbital lobotomy, which entailed rendering the patient unconscious with electroshock, lifting the patient's eyelid and inserting an ice pick-type tool, and pounding it into the brain about seven centimeters with a hammer. Then he would stand behind the patient and pull up on the ice pick or move it from side to side to damage the frontal lobe nerve fibers, and pull it out. He often did both eyes at the same time. ${ }^{44}$ This was not a precision brain surgery, but an infliction of damage on part of the brain in hopes of reducing psychotic symptoms or uncooperative behavior. Dr. Freeman traveled from state hospital to state hospital performing the lobotomies, including West Virginia's state mental institutions.

Dr. Thomas Knapp, who served as superintendent of Spencer State Hospital and then Weston State Hospital when lobotomies were performed in the late 1940s and early 1950s, shared his opinions of the procedure in an interview with Sandy Wells of the Charleston Gazette in 1980. Dr. Knapp felt that lobotomies were completely ineffective and that most lobotomized patients either returned to mental institutions or were "little more than zombies, sitting around their homes." Dr. Knapp recalled that after the procedure the patients 
had huge swollen black eyes. He explained the purpose of the surgery was to cut the connections between the frontal lobe, where thoughts originate, and the middle of the brain where emotions arise. Some patients were blinded and some died from hemorrhaging of the brain. Dr. Freeman performed or supervised 775 lobotomies at the five West Virginia mental hospitals, and West Virginia became the first state to practice transorbital surgery on a large scale. A psychiatric aide at Lakin State Hospital for African American patients, Edith Ross, who was interviewed for the same Gazette article, recalled Freeman's work. He would perform forty or fifty lobotomies in one day, with each completed in about ten minutes. A nurse, Helen Culmer, assisted Freeman, and described him as "crude." She recalled one patient who was bleeding heavily, and rather than try to save him, Freeman just said, "Forget this one. Move on." She recalled the ice pick used in lobotomies as being "as big around as my finger." She continued, "Some were helped. But a couple went blind. Some were paralyzed. And several didn't make it through the night." ${ }^{\prime 45}$

It is important to realize that the lobotomy was seen as a modern miracle cure in the late 1940s. Dr. Freeman saw himself as bringing hope to hopeless people. Though some physicians had doubts about the procedure, at that time it was considered unethical to criticize another physician publicly. There might be discussions at a meeting, but no one would publish an article disapproving of this procedure. ${ }^{46}$ To overwhelmed physicians at mental institutions, lobotomy seemed like a miracle cure. If a patient lived in constant terror due to hallucinations, the relief a lobotomy could bring to that person seemed

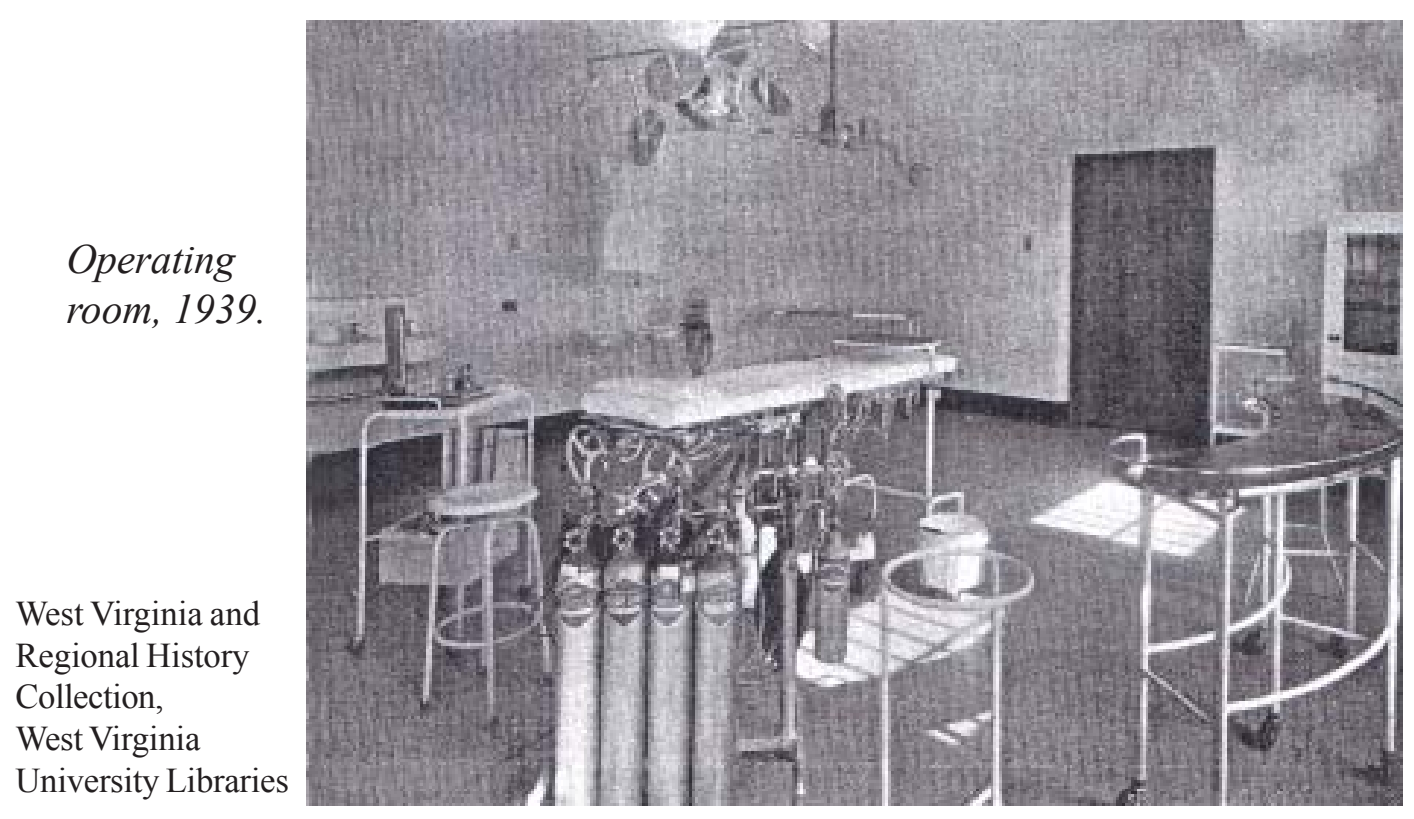


worth any other reduction in their abilities. If a patient was violent, this seemed better than the use of constant restraints and seclusion. There were 150 lobotomies performed in the United States in 1945, and by 1949 there were 5,000. ${ }^{47}$ Lobotomies were being performed at Johns Hopkins, Massachusetts General Hospital, the Mayo Clinic, and other elite institutions. ${ }^{48}$ In a 30-day period in 1952, Dr. Freeman embarked on what he called his "West Virginia lobotomy project." He performed 236 lobotomies, an average of eight per day, many of them at Lakin State Hospital for the Colored Insane. ${ }^{49}$ The introduction of Thorazine as a chemical lobotomy in 1954 did away with the need for surgical lobotomies. Dr. Freeman continued to perform them until 1967, when his patient died from a brain hemorrhage on the operating table (not the first one who had died during this procedure) at Herrick Memorial Hospital in Berkeley. He was stripped of hospital privileges and soon retired. Dr. Freeman continued to crisscross the country, looking up former patients, trying to vindicate his procedure. Lobotomies are still performed, in modified form, on rare cases of obsessive-compulsive disorder in hospitals around the world. ${ }^{50}$

The deterioration at Weston and the state's other mental health institutions due to overcrowding and underfunding was illustrated in a series of articles in the Charleston Gazette in January of 1949. Staff writer Charles Armentrout visited all the state's mental institutions and found that patients lived monotonous lives in crowded, foul smelling wards, receiving little attention or care, and had virtually no privacy. The patients' rooms were poorly lit with bare light bulbs, crowded with rusting beds, and only a few toilets were available for fifty or sixty patients. In some wards one elderly attendant was responsible for as many as seventy patients. Institutions like Weston had beautiful large lawns with lovely shade trees, but these were rarely used by the patients for walks or recreation because there was not enough supervision available to take the patients outside. ${ }^{51}$

The Gazette articles went on to describe that many patients lived in "miserable depreciated quarters that could never pass minimum inspection standards for domestic animals." ${ }^{52}$ The superintendent of Weston Hospital, Dr. Thomas Knapp, who guided Armentrout through the hospital without avoiding the unpleasant aspects, was honest about the conditions and wanted to publicize the need for reform. He showed Armentrout a three-story building that had been condemned for five years, but was still being used to house male patients. Armentrout described the stench that rolled from the building as you opened the door and the sad, shuffling patients living within, cared for by one aide. Parts of the ceiling plaster were falling in, and four-by-fours braced the walls and ceiling to 
prevent more cave-ins. Next they visited the more restless patients held upstairs. One toilet was available there for the 57 patients, in an odorous, water-covered lavatory. One attendant cared for this group, many of whom were not able to control their bodily functions. Disinfectants could not cover the odors. The attendant showed his living quarters behind a padlocked door, a poorly furnished room where he retired for the night while another attendant covered the night shift. Armentrout's conclusion was that the conditions were not the fault of the people running the mental hospitals, but the responsibility of the people of the state who needed to provide more funding to improve the shameful conditions. ${ }^{53}$

Dr. Knapp also showed Armentrout another ward for disturbed female patients, where each morning the women left their crowded rooms and spent their day in the long, dingy, ill-lighted hallway of the ward. They rocked in rocking chairs or paced up and

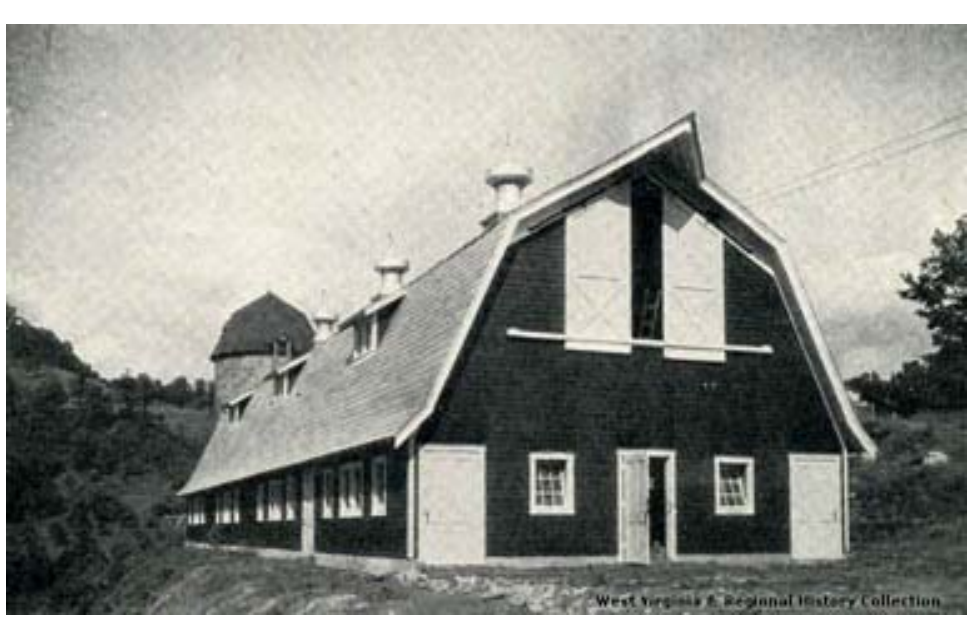

Hospital dairy barn, exterior and interior, 1930.

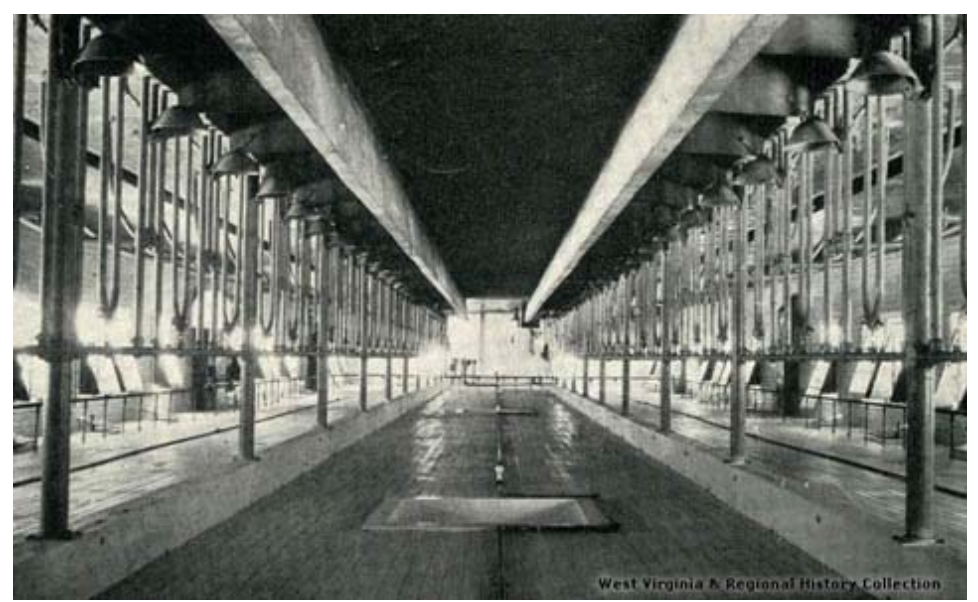

West Virginia and Regional History Collection West Virginia University Libraries down the corridor. Particularly some of the elderly attendants had developed a parental care for their patients, many of whom had the minds of children. The attendants had no training in caring for the mentally ill, and the turnover rate was very high. Many of the patients went barefoot, of their own choice. Dr. Knapp pointed out that this was not the best place to go without shoes because of the condition of the deteriorating, splintering floors that emitted their unpleasant smells. He explained that it was impossible to clean the floors adequately after ninety years of being defecated and urinated on. Armentrout 
commented, "The State of Virginia provided 30-inch thick, hand-hewn stone to build the main unit of Weston. The people of West Virginia are spared the sight of what goes on inside." ${ }^{54}$

Armentrout also found some things at Weston to praise. He described the dairy barn, which appeared fresh and natural and far more pleasant than some of the wards for humans. Dr. Knapp explained how they had to meet high standards for the cows in order to be approved by the health department and to be able to use the milk. Armentrout believed that Dr. Knapp should be given credit with attempting to make improvements at Weston. They viewed the modern, remodeled sections of the main building of the hospital, the area that had been rebuilt after the fire several years before. These seven wards were odorless, clean, and refreshing. Dr. Knapp explained that seeing the improved wards

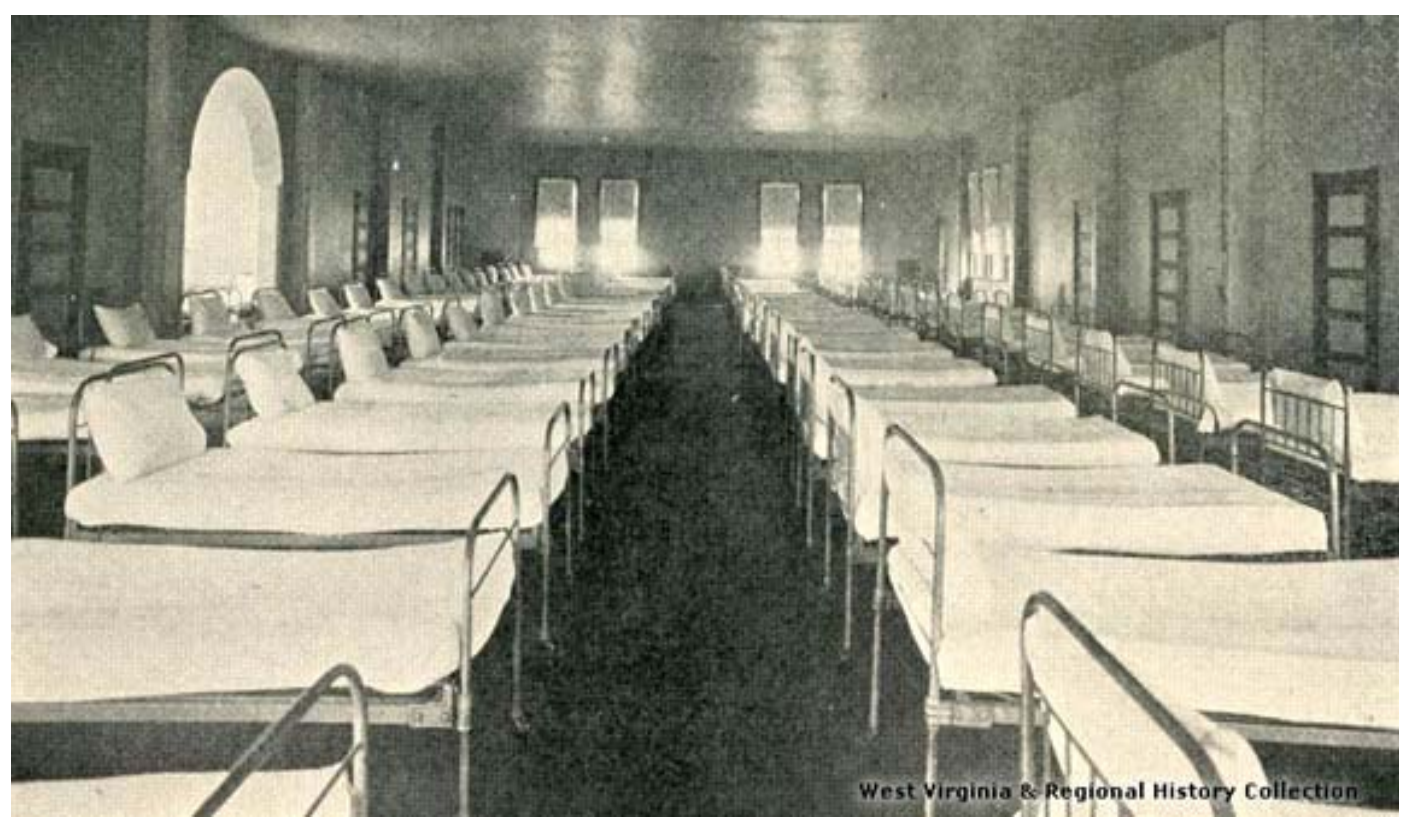

Crowded dormitory in 1924.

West Virginia and Regional History Collection West Virginia University Libraries

was what had convinced him to accept the position of superintendent, seeing that improvements could be made. A ward for the least disturbed female patients was even more pleasant, with an agreeable, carpeted sitting room. This was quite a contrast from other areas of the hospital where patients sat in restraints, arms lashed to their sides in "camisoles." ${ }^{\prime 55}$ In inspecting one men's ward, Armentrout found a pleasant day-room with tables, chairs, playing cards, and checkers, where the men were brought in the morning. Only a few were in the room, however, and the attendant showed him that many of them pre- 
ferred to stay in the toilet. Many of them dragged their favorite chairs in there, where Armentrout saw twenty or more sitting. Dr. Knapp pointed out that because of the overcrowding, only the worst cases were being committed to Weston, and most were deteriorated and difficult to restore to health. ${ }^{56}$

Charles Armentrout's articles were among the many exposés being written about many state hospitals in the late 1940s. The term "snakepit" was used for mental hospitals after World War II, when a novel was published by May Jane Ward in 1946 called The Snake Pit. It was serialized in the Reader's Digest and then made into a successful film, nominated for an Academy Award in 1946, starring Olivia De Haviland. The title came from the novel: "Long ago they lowered insane persons into snake pits; they thought that an experience that might drive a sane person out of his wits might send an insane person back into sanity. ${ }^{\text {"57 }}$ Ward had been a patient at Rockland State Hospital in New York. So, the term snakepit meant "an overcrowded, custodial institution." ${ }^{58}$ More critical books were written throughout the 1960s and 1970s. Irving Goffman wrote Asylums in 1961. He considered mental hospitals worse than inadequate, but coercive and oppressive. He argued that they were not humanitarian in intent, and that they worsened the mental state of those admitted. Gerald Grob wrote several less disparaging books and articles from 1966 to 1991, including The State and the Mentally Ill: A History of the Worcester State Hospital in Massacbusetts, 1830-1920. All Grob's books traced the history of mental institutions and saw them as humanitarian endeavors. They began as asylums to cure mental illness but developed into custodial facilities. Michel Foucault's Madness and Civilization in 1965, David Rothman's The Discovery of the Asylum in 1971, and Andrew Scull's Museums of Madness: the Social Order of Insanity in Nineteenth Century England in 1979 discussed the "social control" perspective. They saw institutions as built to prevent disorder or to protect economic self-interests. ${ }^{59}$ The public and professional opinion of mental institutions was increasingly unfavorable and caused a recognition of the need for reform.

In 1953, mental hospital supervision in West Virginia was transferred from the State Board of Control to the newly established State Department of Mental Health. At this time, Weston State Hospital ranked near the bottom of all the states and the District of Columbia in almost every category measured to compare state mental institutions. In fact, no state institutions were meeting APA standards, so this was a nationwide problem. The ratio of physicians to patients at Weston was one per 248, with the national average being one per 191. Most of the physicians in West Virginia's state hospitals were licensed to 
practice only in these hospitals because they were graduates of foreign medical schools. They had not qualified by examination to practice in communities in the United States. The ratio of professional patient care personnel (physicians, psychologists, social workers, and registered nurses) to patients was one to 67 at Weston, with the national average one to 36 . The average daily maintenance expenditures for each patient per day ranked fiftieth at $\$ 1.90$ per day per patient. The national average was $\$ 3.18 .^{60}$ In the spring of 1958 , a survey team from the Public Health Service visited all the West Virginia state hospitals, and though one said, "It was like going back in time fifty years," they also reported that, "Great credit must be given to all those who are involved in caring for the 6000 patients....they are devoted and dedicated and doing the best they can." ${ }^{\prime 11}$ In one comparison with other states, West Virginia made a better impression. As a percentage of total expenditures of its budget, West Virginia spent more than fifteen other states did on state mental hospital operating expenditures. ${ }^{62}$

By the mid-1950s, many antipsychotic drugs were being introduced. In 1954 chlorpromazine was introduced into the United States, under the name Thorazine, and became one of the most widely used drugs in mental institutions. It was actually introduced as a

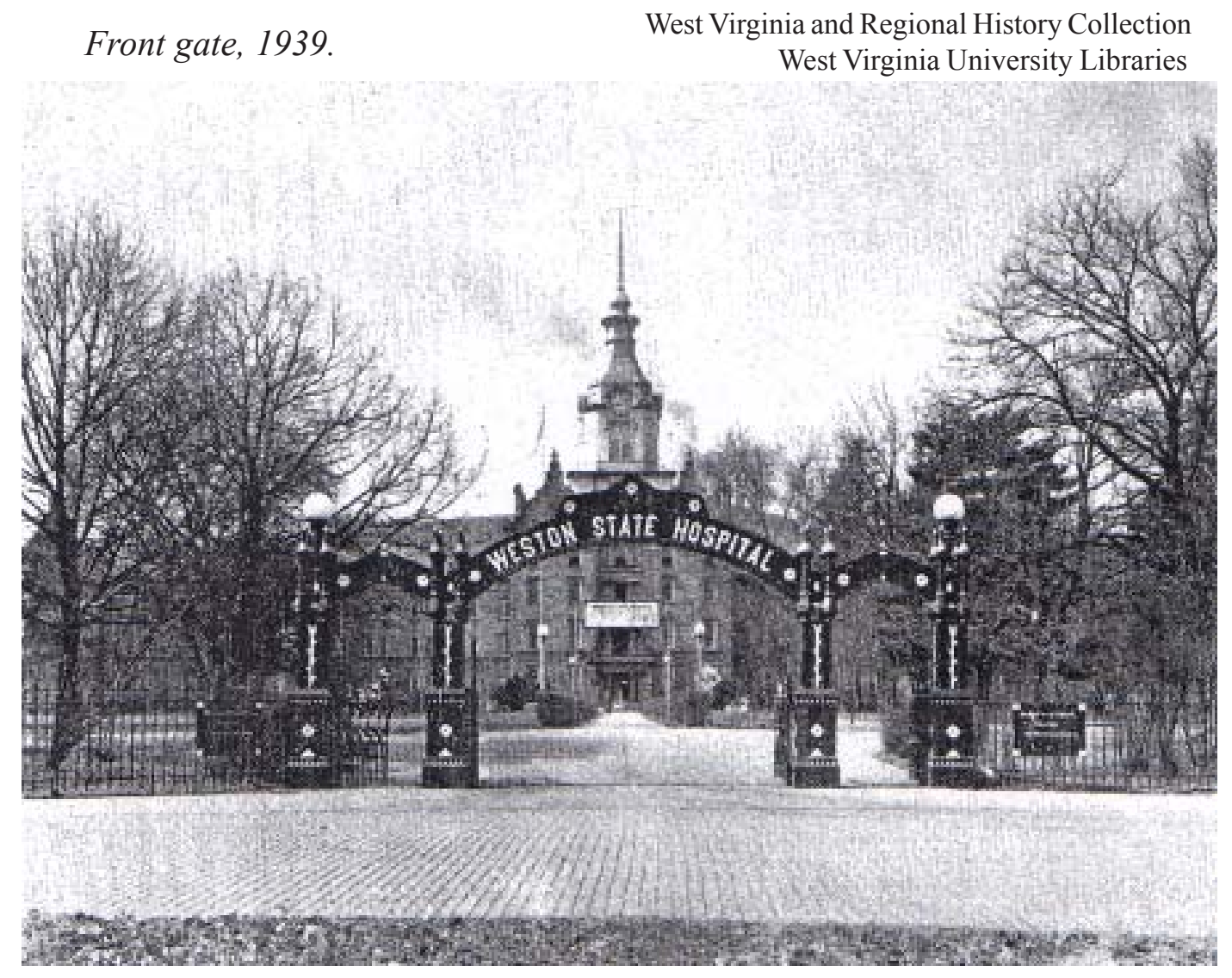


pill that hindered brain function, similar to a lobotomy. A French neurologist, Dr. Henri Laborit, had been using chlorpromazine as a pre-anesthesia sedative. He noticed it sedated agitated patients, so he suggested psychiatrists use it on psychotic patients. It worked to reduce delusions and hallucinations, and is still used under name Thorazine. ${ }^{63}$ Within a decade it was marketed as an antipsychotic medication under the growing influence of the pharmaceutical industry. Thorazine was by the mid-1960s believed to be a cure for schizophrenia. Drugs that were originally used as a way to calm manic patients on a short-term basis had become accepted as medications that needed to be taken continuously. This was helpful to state governments who wanted to lessen their populations at mental institutions, as well as to pharmaceutical companies which were guaranteed life-long customers for their products. ${ }^{64}$

As antipsychotic medications were introduced, more patients were able to manage their illnesses on an outpatient basis, as long as they would continue on their medications. In recent decades, neurologists have come to believe that many mental illnesses are caused by too much dopamine in the brain, which acts as neurotransmitter, carrying messages in the brain. Antipsychotics block the absorption of dopamine, which helps the thinking and feeling region of the brain, but can also cause side effects. Physical motion can be affected, and patients may walk with a stiff gait or lose the mobility of their facial muscles. Other side effects are Parkinsonian symptoms, blurred vision, rapid heartbeat, extreme restlessness or sedation, and a slowing of thinking and movement. Twenty percent of patients have tardive syskinesia (delayed, distorted movement—-tics, facial grimaces, jerky movements). One of the newer drugs, Clozapine (Clorozil), does not cause tardive syskinesia; and it alleviates the delusions and also lifts patients from lethargy. However, its side effects are drooling, weight gain, and bone marrow problems that require patients to have a weekly white blood cell count. ${ }^{65}$ Apparently many of the mannerisms and tics that one might think are signs of mental illness could be caused, instead, by the medications given to control mental illness.

Although overall conditions at Weston in the 1950s and 1960s were poor because of overcrowding and an inadequate staff to provide needed treatment, attempts were made to make life more enjoyable for the patients by the staff and volunteers from the community. Dances, movies, and concerts by the local high school band provided entertainment for the patients. A patient newsletter published by the recreation department in the 1950s, the Westoneer, mentioned many volunteer groups helping out with the patients. One group 
found that one of the wards was cold, so they collected sweaters for the patients. Student nurses came from several colleges in the area for part of their training. Entertainment like ping pong tournaments and basketball teams were organized—some teams mentioned were the "Prisoners" and the "Veterans." (There was a section of the hospital for veterans called the Soldiers Home.) So, though the Westoneer newsletter included dismal facts (the American Psychiatric Association's standard was to have at least twenty-seven physicians for 2,300 patients, and Weston had only ten), it also mentioned kindnesses (someone had donated a trip to the circus for forty-one of the patients, and sixty cakes had been donated for a cakewalk). ${ }^{66} \mathrm{~W}$ ith conditions as dire as they were for many, there were people trying to make a difference in the lives of the patients. As society began to see the deficiencies of the mental institutions, government policies and patients lives would begin to change drastically in the next several decades.

A major change in mental health services occurred with the gradual involvement of the federal government. Until 1946, mental health care had been considered a state or local responsibility. In 1946, the federal government passed the National Mental Health

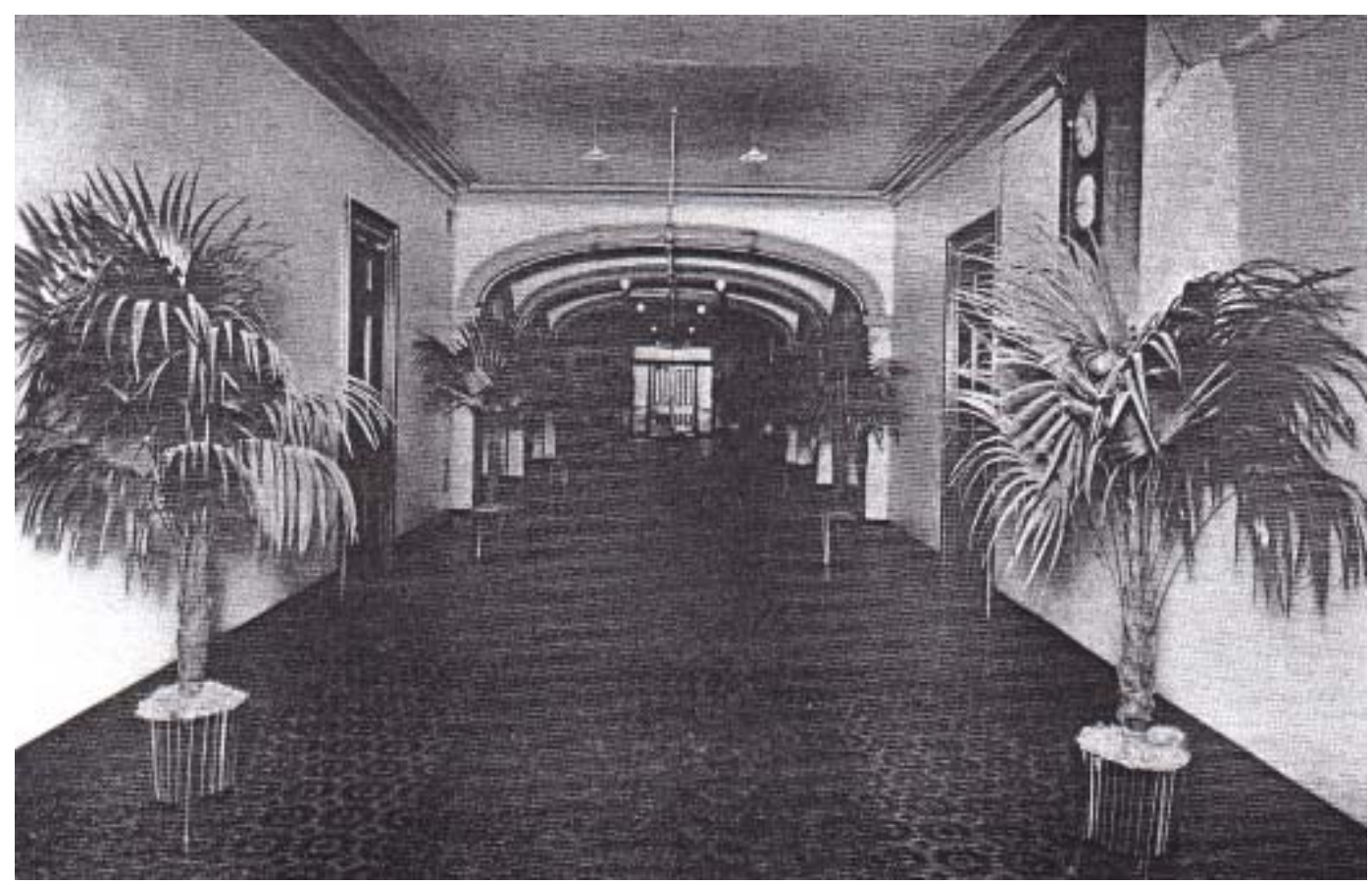

Entry hallway of center building, 1903.
West Virginia and Regional History Collection West Virginia University Libraries 
Act, creating the National Institute of Mental Health, and began to issue grants to states for mental health services. There were several reasons this national legislation had passed. Over one million men had been rejected from service in World War II because of mental health problems, the most common cause for rejection. Forty percent of medical discharges from the armed forces were for psychiatric disorders. After the war, half of disability pensions were for psychiatric problems. The number of mental patients had continued to rise, with over 600,000 hospitalized for mental illness nationwide. Also, many books were being published which exposed poor conditions at state mental institutions. Albert Deutsch's The Mentally Ill in America was published in 1937. Asylum by William Seabrook was another. Reports had also come out about hospital conditions from conscientious objectors who had served in mental hospitals during the war. The federal assistance provided by the 1946 National Mental Health Act was gratefully received by the states, but much of the grant money from this bill went into research and to community mental health programs, rather than to hospital assistance. ${ }^{67}$

Notes

${ }^{1}$ Fourth Biennial Report of the State Board of Control of West Virginia for the Period July 1, 1914, to June 30, 1916 (Charleston, WV: Tribune Printing Company, 1916), 45.

${ }^{2}$ Louise B. Gerrard. Mental Health Services: Statehood to 1957. The Department of Mental Health 1957-1968 (Charleston: West Virginia Dept. of Mental Health 1970), 1-2.

${ }^{3}$ Joy Gilchrist-Stalnaker, A Short History of Weston Hospital (Weston, WV: Hacker's Creek Pioneer Descendants, 2001), 2.

${ }^{4}$ Edward Conrad Smith, A History of Lewis County, West Virginia (Weston, WV: the author, Morgantown Printing and Binding, 1920), 395.

${ }^{5}$ George Dowdall, The Eclipse of the State Mental Hospital: Policy, Stigma, and Organization (Albany, NY: State University of New York Press, 1996), 43.

${ }^{6}$ Richard L Lael, Barbara Brazos, and Margot Ford McMillen, Evolution of a Missouri Asylum: Fulton State Hospital, 1851-2006 (Columbia, Missouri: University of Missouri Press, 2007), 78.

${ }^{7}$ Gilchrist-Stalnaker, Short History of Weston Hospital, 7.

${ }^{8}$ Chapman, History of Weston Hospital, Vol. 2, (Weston, WV: by the author, 1988), 8, 16.

${ }^{9}$ Ibid., 19.

${ }^{10}$ Report of the Directors, Superintendent and Treasurer of the West Virginia Hospital for the Insane for the Years 1889 and 1890 (Charleston, WV: Moses W. Donnelly Public Printer, 1890), 49.

${ }^{11}$ Chapman, History of Weston Hospital, Vol. 2, 17-18.

${ }^{12}$ Reporter's Transcript in the Case of Hearing Before the State Board of Control, Fairmont, WV: August 1927. 
${ }^{13}$ Robert Whitaker, Mad in America: Bad Science, Bad Medicine, and the Enduring Mistreatment of the Mentally Ill (Cambridge, MA: Perseus Publishing, 2002), 75.

${ }^{14}$ Ibid., 75-77.

15 "Youth Admits Starting Weston Hospital Blaze, Reveals Series of Fires," Clarksburg Exponent, October 27, 1935, 1.

16 “Six State Hospital Wards Destroyed by Fire," Weston Democrat, October 4, 1935, 1.

17 "Control Board Considers Plan for Rebuilding," Weston Democrat, October 11, 1935, 4.

18 "Weston Fire Chief Proves Hero of \$150,000 Blaze as 500 Insane Men March From Fire Swept Hospital," Clarksburg Exponent Telegram, October 4, 1935, 1.

${ }^{19}$ Gilchrist-Stalnaker, Short History of Weston Hospital, 6.

20 "Six State Hospital Wards Destroyed," Democrat, 1.

21 "Control Board Considers Plan for Rebuilding," Democrat, 4.

22 "Six State Hospital Wards Destroyed by Fire," Democrat, 1, 6.

${ }^{23}$ Ross White interview, February 16, 2006.

24 "Youth Admits Starting Weston Hospital Blaze, Reveals Series of Fires," Exponent, 1.

25 "Six State Hospital Wards Destroyed," Democrat, 1.

${ }^{26}$ Gilchrist-Stalnaker, Short History of Weston Hospital, 7.

${ }^{27}$ Ross White interview, February 16, 2006.

${ }^{28}$ Lawrence Chapman, Weston Hospital in Transition (Weston, WV: by the author, 1989), 99.

${ }^{29}$ Jean White interview, February 8, 2008, 10.

${ }^{30}$ Sixteenth Report of the West Virginia Board of Control 1948-1951. Compiled by Robert G.

Hanlen in conjunction with the superintendents of the institutions and under supervision of the Board of Control, 1951, 14-15. $2005,5 B$

${ }^{31}$ Scott Finn, “Mentally Ill Neglected Throughout State's History,” Charleston Gazette, January 2,

32 Board of Control Report 1948-1951, 19.

${ }^{33}$ Harry Garrison, Superintendent. Letter to Joseph Terrell, President of WV Board of Control, September 9, 1943.

${ }^{34}$ Board of Control Report 1948-1951, 37-39.

${ }^{35}$ Ibid., 27.

${ }^{36}$ Henry Garrison, Superintendent. Letter to Joseph Terrell, President of the Board of Control, August 16, 1943. West Virginia Collection, West Virginia University Library, Microfilm 1976, reel 13.

${ }^{37}$ Board of Control Report 1948-1951, 20-22.

${ }^{38}$ Ibid., 25.

${ }^{39}$ Whitaker, Mad in America, 98-99.

${ }^{40}$ Ibid., 100.

${ }^{41}$ Ibid., 99-106.

${ }^{42}$ Board of Control Report 1948-1951, 23-28.

${ }^{43}$ Whitaker, Mad in America, 108-124.

${ }^{44}$ Ibid., 125-133.

${ }^{45}$ Sandy Wells, “American's Lobotomy Era Dawned in West Virginia," Charleston Gazette, October 22, 1980, $1 \mathrm{D}$.

${ }^{46}$ Barak Goodman and John Maggio, The American Experience: The Lobotomist, program transcript, Boston: Public Broadcasting Service, WGBH, 2007 [internet]; available from http://www.pbs.org/ wgbh/amex/lobotomist/program/pt.html, accessed 22 January 2008.

${ }^{47}$ Barak Goodman and John Maggio, The American Experience: The Lobotomist, 9.

${ }^{48}$ Ibid., 10.

${ }^{49}$ Ibid., 11.

${ }^{50}$ Ibid., 13-14.

${ }^{51}$ Armentrout, Charles R., "The Price of Economy-Misery! Mental Patients Doomed to Lives of Neglect, Monotony, Indecency,” Charleston Gazette, January 23, 1949, 1.

${ }^{52}$ Armentrout, Charles R., "The Price of Economy-Misery! Inmates at Weston Have to Live in Quarters Unfit for Livestock,” Charleston Gazette, January 24, 1949, 1.

${ }^{53}$ Ibid., 1, 14. 
${ }^{54}$ Armentrout, Charles R., "Forsaken and Forgotten: 15 Incontinent Women, Scantily Clad, Sit All Day in Smelly Room at Weston," Charleston Gazette, January 25, 1949, 1, 7.

${ }^{55}$ Armentrout, Charles R., "Forsaken and Forgotten: Weston Has State's Best in Mental Patient Care," Charleston Gazette, January 26, 1949, 1, 14.

${ }^{56}$ Armentrout, Charles R., "Forsaken and Forgotten," Gazette, 4.

${ }^{57}$ Dowdall, The Eclipse of the State Mental Hospital, 139.

${ }^{58}$ Ibid., 139.

${ }^{59}$ Dowdall, Eclipse of State Mental Hospital, 13.

${ }^{60}$ Gerrard, Mental Health Services, 19-20.

${ }^{61}$ Louise B. Gerrard, “The Department of Mental Health,” excerpted from "Impact of a Federal Grant-in-Aid Program on an Economically Depressed, Rural State: A Case Study of Mental Health Programs in West Virginia," (Ph.D. diss., Department of Public Law and Government, Columbia University, 1969), 1011.

${ }^{62}$ Louise Burr Gerrard, Impact of a federal grant-in-aid program on an economically depressed, rural state: a case study of mental health programs in West Virginia. Ann Arbor: University Microfilms International, 1969, 114.

${ }^{63}$ Lisa Berger and Alexander Vuckovic, Under Observation: Life Inside the McLean Psychiatric Hospital (New York: Penguin Books, 1995), 68-69.

${ }^{64}$ Whitaker, Mad in America, 142-158.

${ }^{65}$ Berger and Vuckovic, Under Observation, 141.

${ }^{66}$ The Westoneer, January through June issues, 1954 [West Virginia Collection, WVU Library].

${ }^{67}$ Gerrard, Impact of a federal grant-in-aid, 24-27, 31. 


\section{Chapter three: 1950-1994}

Life in Weston State Hospital was a busy combination of three shifts of employees who attended to many different types of patients: the long-term chronic patients, shortterm crisis patients, court-ordered criminal patients, and those suffering from cyclical illnesses or substance abuse who might come in and out of the hospital repeatedly. The patient population at Weston remained very high throughout the 1960s. It was not until 1968 that the numbers fell below two thousand. There were still 1,500 patients there in 1972, and then about 1,000 in $1976 .{ }^{1}$

In the 1970s and 1980s, sharp declines in patient population occurred in what was a nationwide trend toward deinstitutionalization. Even as the numbers gradually decreased, the employees of Weston Hospital were part of a community that had a huge task to perform. Caring for a large population of any sort is a logistical challenge (such as schools), but when the large population is mentally ill, developmentally disabled, or addicted, it is difficult for us to imagine the challenge of the day-to-day lives of both the patients and the employees.

This chapter is based, in large part, on interviews conducted with former employees of Weston State Hospital. The interviewees were: Michael Todt, Director of Clinical Services; Ruth Lowther, health service worker; Karl Staubly, alcohol and substance abuse counselor; Shirley Mason, registered nurse; Mildred Haller, business office employee; Thom Haller, student recreation department employee; a security guard who asked to be referred to only as "Bill"; and a housekeeper who wished to remain anonymous. I also interviewed my mother, Jean White, as a citizen of the town of Weston and a volunteer at the hospital. These employees worked in various periods from the 1950s to the closing of the hospital in 1994, and then some continued employment at the William R. Sharpe, Jr. Hospital, which replaced the Weston facility at that time. Additional information about these people and more of their interesting experiences are recorded in the appendix of this paper. My thanks to them for sharing their memories. 


\section{0s: Softball teams to shock treatments}

The patient population at Weston State Hospital peaked in the 1950s and 1960s with over 2,300 patients. The 1951 Annual Report of the Board of Control stated that the total patient population was 2,319, complained of overcrowded conditions, and told of the plea by county officials to take patients housed in jails throughout the state. ${ }^{2}$ The hospital in its full life may be difficult to conceptualize for those who were never there. Some information from a 1953 hospital newsletter illustrated the magnitude of the organization. Imagine a place so large that 48,000 sheets were washed in one month. ${ }^{3}$ Meals were prepared three times a day for 2,500 people, plus a supper for the midnight staff. The baker, a Mr. K. O. Thompson, made 700 loaves of bread each day. ${ }^{4}$ The 583 -acre farm was still producing a large amount of food for the hospital. Ray Currey was the farm superintendent, with an employee staff of ten farmers and ten patients. The farm had a dairy herd, "one of the best Holstein herds in the state," of one hundred, and also had three hundred hogs. The coal mine was still producing all the coal the institution needed. ${ }^{5}$

The patients at Weston State Hospital in the second half of the twentieth century were ones of all ages and mental illnesses. First we might consider, what is insanity? As Albert Deutch explained in his 1948 book, The Shame of the States, "A man or woman considered 'insane' in one community or social setting may be regarded as just queer or eccentric in another. Any psychiatrist will tell you that many inmates of mental hospitals are less disturbed than many people on the outside, including some who have achieved outstanding success in social, economic, and artistic life." $\mathrm{He}$ went on to argue that it is difficult for people to even confront the problem of mental illness. People are uncomfortable with it because mental illness threatens us all. All of us face anxieties, depressions, and emotional problems. Most handle their slight mental health problems with suppression. "They plunge into their business or their play... and try to forget. To be reminded of the mental hospitals is to be reminded of people who have failed, who have been unable to escape their anxieties. And to be reminded of these sufferers makes some people more uncomfortable about their own problems."7

There were people with a range of mental problems at Weston State Hospital, and a number of people who were perhaps not mentally ill at all or had recovered from previous illnesses. Common disorders at Weston included manic depression [bipolar disorder], schizophrenia, depression, dementia, mental retardation, and alcohol and drug addiction. The number of staff responsible for caring for the large population of patients 
was inadequate throughout the 1950s and 1960s. The ratio of staff to patients remained low until the last decade or so of the hospital's existence, when the patient population declined. Mrs. Lowther, a health service worker, or aide, who began working at Weston in 1968, recalled how very crowded the hospital was in the 1960s, with often over fifty patients on a ward. Two aides might have the responsibility for as many as sixty-five patients. There was only one licensed practical nurse in the entire hospital when she began working there in 1968. The aides were taught to perform nursing duties such as giving medications, taking blood pressures, and giving injections. These were just some of their many duties, which included custodial work in addition to supervising the patients. ${ }^{8}$

The number of physicians was inadequate as well. These physicians were not psychiatrists, but family practitioners, internists, and others. At the most there was one psychiatrist on the staff. The physicians at Weston State Hospital were primarily foreign. ${ }^{9}$ Mrs. Haller, who worked in the business office in the 1950s, remembered that one doctor was from Germany and one from Great Britain. Neither of them remained long at the hospital. Dr. Weatherhead, from Great Britain, was very well respected and spent just one year at Weston. Dr. Cheng and Dr. Chu were two Chinese physicians. She could not recall which was which, but one was female and had a baby. Mrs. Haller laughed at how she and the other office girls were so excited to see a little Chinese baby. ${ }^{10}$ A 1951 Board of Control Report mentioned both of these physicians. Dr. Johnson Chu was a staff physician who was awarded a Fellowship in the American College of Cardiology in June of 1951. Dr. Sylvia Cheng directed the tuberculosis department at Weston. She earned a Certificate of Fellowship in the American College of Chest Physicians (Tuberculosis) in 1951. The TB unit at Weston serviced the whole state's population of mentally ill/tubercular patients. At that time they had 279 beds. ${ }^{11}$ Mrs. Haller stated that the foreign doctors did not have the licensure in the United States to set up private practices, but perhaps could earn certification after a certain amount of time. They were allowed to practice medicine in the state hospitals and to prescribe medications, but Weston and other state facilities were not accredited hospitals. Mrs. Haller also recalled one American physician who had lost his license due to drug addiction, but was allowed to work at the state hospital. She felt sure they must have "kept an eye on him." 12 Throughout the next few decades there would be doctors at Weston from the Philippines, India, and many other nations. 
In the 1950s, it was fairly easy for a family to have someone committed to a state hospital. People were sometimes taken there because there was such a stigma to having a mentally ill person in the family - they got rid of them as quickly as they could. There were mentally deficient children in the hospital in the early days, and some of the mentally retarded patients Mrs. Haller knew in the 1950s were ones who had grown up in the hospital. There were some who came into her office often and were very pleasant and friendly, but "like grown-up children." One was a man who called himself John D. Rockefeller and "thought he owned the place." He was always telling them how he was going to get them money to improve things. ${ }^{13}$ Another nice man who was a gardener brought them flowers. Mrs. Haller remembered that there were many patients in the hospital because of venereal diseases. Many of them had been children born with mental problems because their parents had had these diseases.

There were many patients at Weston in the 1950s who were women diagnosed with involutional psychosis, menopausal problems. Over time medications were developed for that, but in the fifties, as Mrs. Haller pointed out, "I suppose some of them, once they got in there, they never got out. I wouldn't doubt that with some of the people - it was 'Oh, we don't want them around.' Especially if they had embarrassed their families in any way." ${ }^{14}$ Jean White, who volunteered with a church group at the hospital, recalled her aunt being admitted to Weston State Hospital in 1953. She had been acting strangely and was admitted voluntarily. She was in her fifties and had been taking hormones for menopausal problems, so perhaps that was the reason she was there. She remained in the hospital for about a month and received shock treatments. Mrs. White said that her aunt seemed very normal every time she talked to her, and that she told Mrs. White she hated the shock treatments. ${ }^{15}$ Mrs. White remembered her aunt stayed in a separate building for paying patients. The 1951 hospital report mentioned that there was a separate Medical Center for paying patients. It had 109 beds, twenty in dorm rooms and the rest in private rooms. The private rooms had been constantly occupied that year, and normally two RNs were on the staff there. At that time of the report the two RNs had recently resigned, and they had replaced one but still needed another. Two physicians took care of the medical needs of that department. ${ }^{16}$

Mrs. White also remembered a few other patients at the hospital. One was an uncle of her husband, who was taken to the hospital some time after having had a head injury in about 1950. While working with a logging company, a large branch had fallen on his head. 
His employer took him to a chiropractor, who sent him home. His skull was fractured, however, and he was never right after that, mentally. His wife cared for him for several months, but he was like a child, and she finally had him admitted to Weston. He caught pneumonia there and died within a couple of weeks. ${ }^{17}$ Many of the patients at Weston were elderly people suffering from dementia or other problems that made them too difficult for their families.

Another relative that Mrs. White had in the Weston Hospital was a cousin of her father's, named Dey, who had been taken to the hospital at about thirty years old, in about 1930. She spent the rest of her life there. Mrs. White's father used to visit her, and she worked in the sewing room, making dresses and other items. Mrs. White thought Dey was quite normal, but someone who went to visit her related that Dey had greeted her with, "Oh, Mamie Eisenhower is here! How nice of you to come and visit!" So she was not quite right, mentally. (Mrs. White also wondered if Dey's father had been quite "right" because he had named Dey's sisters, who were twins, Liberty and Freedom.) Dey lived at the hospital until her death in about 1970. Mrs. White also knew another woman who had been a patient at Weston in the 1940s after a stressful period in her life had put her over the edge. This woman's husband had died suddenly, after a three-day illness, leaving her with two small children. She had to learn to drive and get a job. She worked as a traveling health nurse and then had an auto accident on a snowy road. Her sister took care of her children

Crowded male ward, 1924.

West Virginia and Regional History Collection

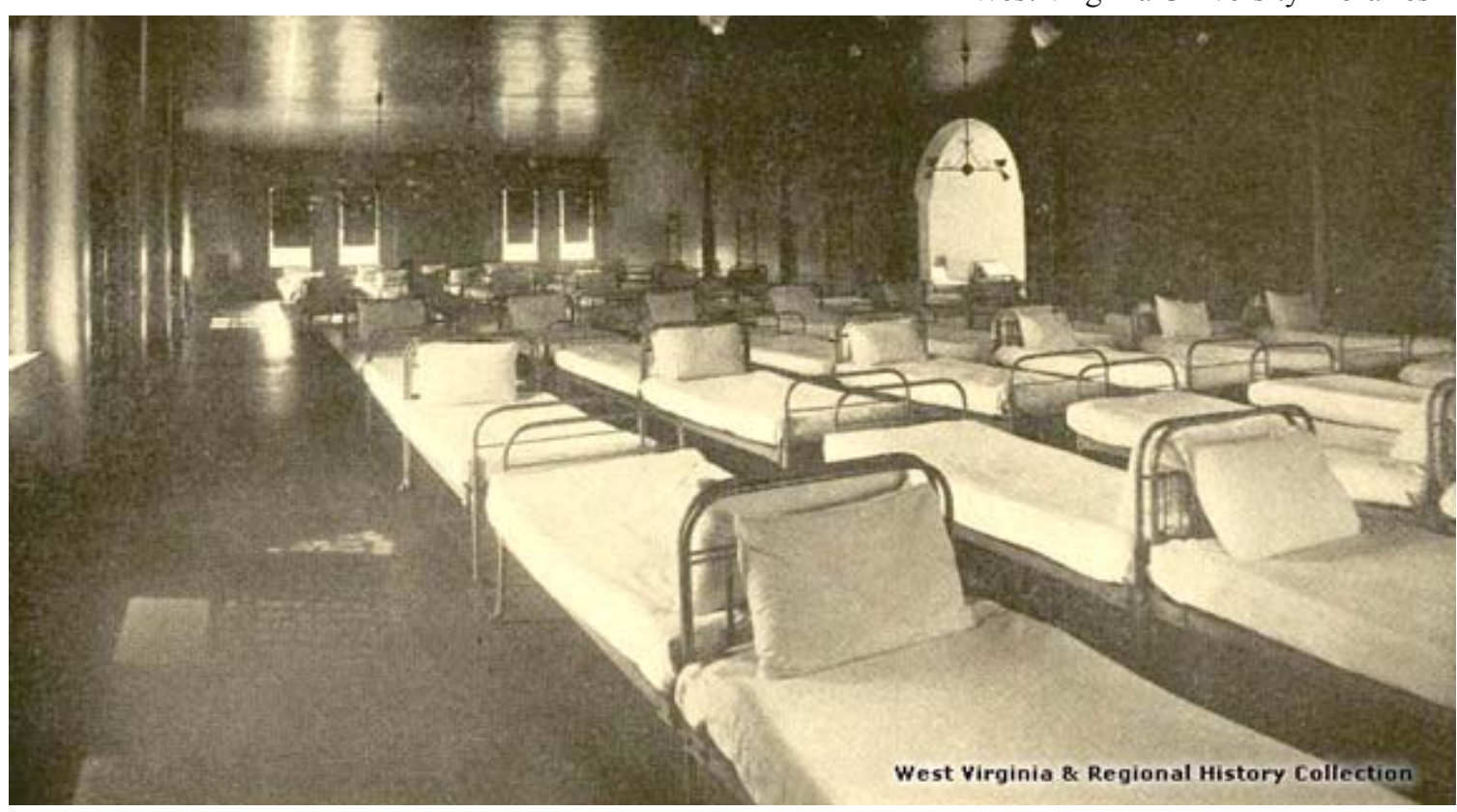


while she came to the hospital for several months because of depression. She was able to return home then, resume her job, and raise her children. ${ }^{18}$ These people are just a few examples of typical patients at Weston. Some might be there for a short time to overcome a stressful life experience, some might have suffered from an accident, and some might spend a lifetime there because they were a bit odd.

Depression was a common illness at the state hospital. Mrs. Lowther, the aide, remembered how depressed some patients could be-so seriously that they did not want to get out of bed or even eat, and had to be force-fed. She also noted the large number of elderly patients, many of them at Weston because they could not afford a nursing home. ${ }^{19}$ Other patients were schizophrenic, some were bipolar (manic depressive), and some had personality disorders. Of course there were many mentally retarded patients, although as the decades went by more of them were moved into the community and into group homes. ${ }^{20}$ Some patients suffered from delusions, hallucinations, or scrambled thoughts. Some were impulsive or out of touch with reality. ${ }^{21}$

All the employees interviewed for this paper had known of people in the hospital who almost certainly did not really need to be there. Sometimes people were admitted with a problem, and perhaps overcame it, but did not return home for years, if ever. Families often did not want to care for a relative that was difficult, or they were embarrassed to have them around. Shirley Mason, an RN at Weston through the 1980s, noted that sometimes a patient still had a family, but that the family "just didn't give a hoot."22 Mrs. Lowther, the aide, once spoke to a doctor about a woman she felt was unfairly committed. She seemed so nice and so down to earth that Mrs. Lowther asked the doctor to talk to her, which she did, and the woman was released. She did not return to the hospital. ${ }^{23}$ Mrs. Haller, in the business office, remembered the gardener in the 1950s, who was such a nice man and did not seem to have anything wrong with him. He did the landscaping and brought in beautiful flowers for the ladies' desks in the offices. She also mentioned the many women admitted for menopausal problems, and some were never discharged. ${ }^{24}$ Mrs. White, as a church volunteer, said that many of the women that they visited with on the ward seemed quite normal. A few were mentally retarded, but the others did not show signs of mental illness. ${ }^{25}$

Mrs. Haller, in the business office, recalled how common lobotomies and shock treatments were in the 1950s. She said none of them thought a thing about people receiving lobotomies, and shock treatments were routine for many illnesses. She also mentioned 
that sterilization of women was common. "If they kept having one right after another and they weren't real mentally sharp, so that's how they'd treat them-so they wouldn't have any more children." ${ }^{26}$ The 1951 Board of Control report stated that the hospital had ordered a new electroshock machine. At that point they were using two machines daily on both the male and female sides of the hospital, and on average a patient received three treatments per week. The report also stated that seventy transorbital lobotomies had been performed thus far, and that Walter Freeman, of Washington, D.C., had been there frequently, conducting post-operative exams. The report listed forty lobotomies in 1948-49, five in 1949-50, and none as of June 1951. ${ }^{27}$ Shock treatment was still being used through the 1960s. Mrs. Lowther, the aide, recalled that when she went to work in at the hospital in 1968, they were transporting patients to the United Hospital Center in Clarksburg to receive shock treatments. She did not know if the treatments were helpful, but she was certain the patients hated them. Mrs. Lowther also remembered a woman who had received a lobotomy. "She was like a walking vegetable," she said. ${ }^{28}$

The mid-1950s saw the introduction of antipsychotic medications. The November 1955 edition of the Weston Hospital patient newsletter, The Westoneer, told of a movie shown to the employees and the public, entitled, "We the Mentally Ill." The film was produced by the Smith, Kline and French Drug Company, developer of the new drug, Thorazine or Chlorpromazine, for treatment of the mentally ill. The film dealt with the treatment of mental patients at St. Elizabeth's Hospital in Washington, D.C. Another film was scheduled, "Chlorpromazine in the Treatment of Psychiatric Disorders." These and other films were part of an educational effort to inform employees and the public of these new treatments being offered in many state institutions. ${ }^{29}$ After antipsychotic medications began to be used, the use of lobotomies ceased. Shock therapy continued, but was less common after the 1950s. From the 1960s until the 1990s, there was little treatment being offered other than medication at the hospital.

While there was little in the way of therapy for most of the patients at Weston, there were a few active programs in the hospital. The occupational therapy department brought different crafts and activities to the wards for the patients to do, and some of them enjoyed these activities. It was difficult to involve all the patients, though, because they were at such different ability levels. For many years the wards were arranged geographically, with patients from certain counties grouped together regardless of their age or type of illness. Later the hospital switched to using a diagnostic system to arrange the wards. 
The recreation department, which was established in 1949, provided activities throughout the last half of the twentieth century. These activities were available to only a limited number of patients, though, generally ones that were in better condition. There were some sports teams organized in the fifties - softball and basketball teams of patients and employees. The recreation department arranged dances for the patients often and also supervised a big field day out on the lawn each summer.

Throughout the 1950s, the recreation department supervised a patient newsletter for the hospital, The Westoneer. A donation was made of several years' worth of these newsletters to the West Virginia Collection of the West Virginia University Libraries, and they are filled with descriptive information about the hospital at that time. Patients and staff contributed poems, jokes, and news items. Each issue contained a letter from the superintendent, an article by a pastor, and a sports section. Community volunteer work was described, such as groups bringing bingo or other entertainment to the patients. Often an article focused on a particular department of the hospital, such as the farm, the laundry, or the dietary department. Accounts of dances, cakewalks, field days, and movies told of the recreation available at the hospital. Below is an example of patient poetry from the August 1955 issue and jokes from the February 1954 issue:

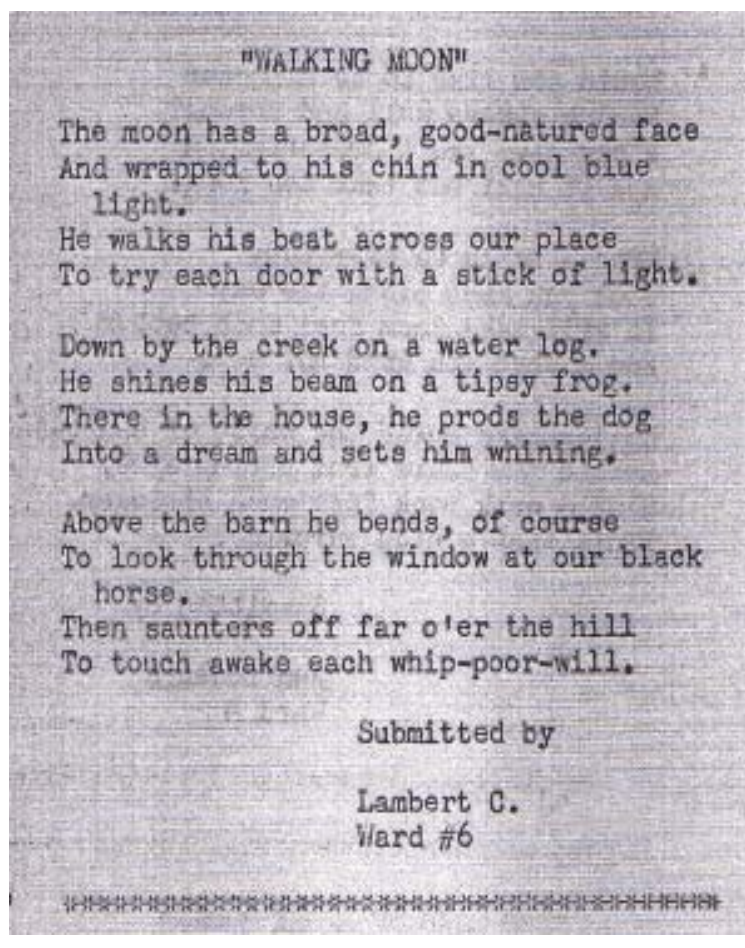

West Virginia and Regional History Collection West Virginia University Libraries

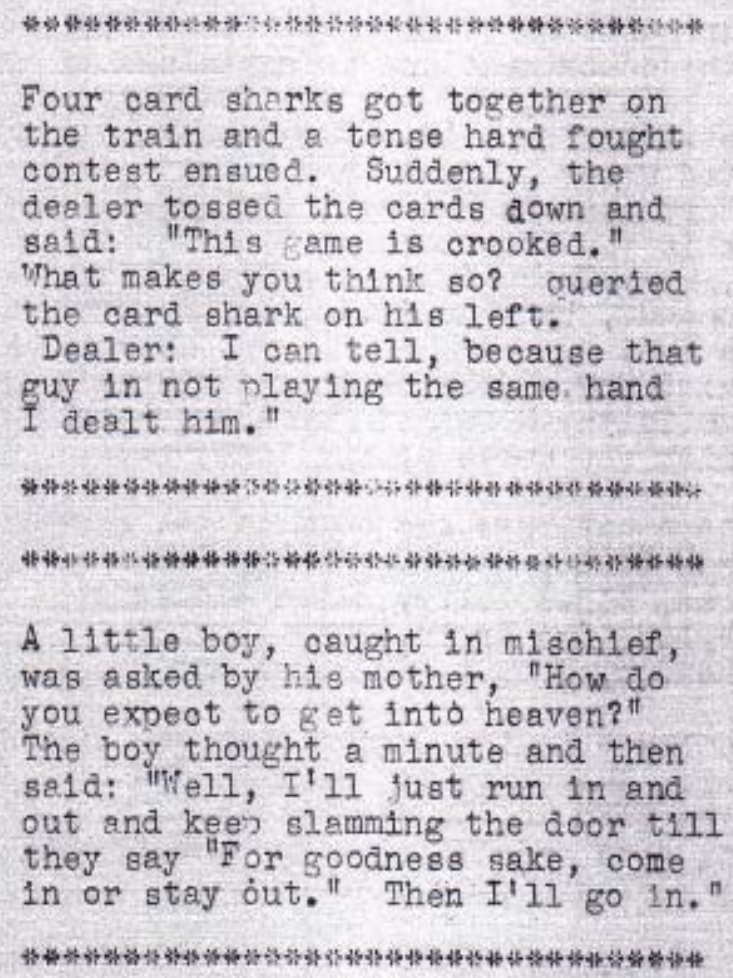


One improvement at Weston State Hospital in the early 1950s was the construction of several additional buildings. Funds were made available from the federal government through the Hill-Burton Act for the construction of new buildings at state hospitals. These funds became available to the West Virginia Department of Health in 1947. Surplus money in the state treasury, left from the lack of building during wartime, was used to receive matching funds from the federal government for construction at institutions. By 1957, construction at state hospitals cost West Virginia $\$ 1,716,242$. The federal government provided $\$ 848,582 .{ }^{30}$

At Weston, a rehabilitation house was constructed in 1948 and a maintenance building in 1953. The Unit I building was completed in 1953, and Unit III in 1954; both were large, four-story, rectangular brick structures behind the main building. Mrs. Haller, in the business office, chuckled about the new forensic building that was constructed in the early 1950s. She and the other office workers were given a tour before it opened. It was supposed to be a perfect, foolproof building designed by a famous architect. She said they had to go through several locks to enter. Within a few months of its opening, however, patients were escaping. Mrs. Haller did not know whether they went out windows, or stole keys, but they escaped the perfect forensic building. ${ }^{31}$ The 1951 Board of Control report described this new Criminal Mentally Ill Building, which had just been completed for $\$ 353,350$. It was two-story, with a dormitory, day room, and toilet space on each wing floor. There were five seclusion rooms. The roof was of concrete, the floors had radiant heat, there was ventilation and air conditioning, and the front was the only entrance. The architectural work was done by a Clarksburg company and the construction by a Morgantown company, and it was "one of the most modern of its kind in the nation." 32 (A later annual report, in 1976, mentioned that this building, originally built as a security building, had at some point been converted to an activities building. Then in 1976 it had been renovated to become, once again, a new forensic building for patients considered highly dangerous. ${ }^{33}$ )

No discussion of the hospital in the 1950s should overlook one story told by Mrs. Haller from her time in the business office. She recalled her supervisor, a man she highly respected:

But Mr. Alfred was a very nice man. You know, [laughs] the state has a tendency to - they would sort of do things sort of underhand once in a while. And oh, he would get so upset. Bob, oh, my goodness, he would get so upset. But I remember one time they sent us a 
whole shipment of high-heeled shoes. And we were supposed to pay for those high-heeled shoes. Now how many patients could wear high-heeled shoes? [laughed] You know, little things like that. He just argued with them. Probably in the end I paid for it. I don't think he got very far with his arguments. Why high-heeled shoes? It was, you know, to help out somebody, you know how they do. They have their buddies and- 34

The hospital's annual report in 1949 mentioned that Mr. Alfred had been appointed Financial Secretary in July of 1949. The report credited him with doing an excellent job of keeping track of government appropriations, allocations, and expenditures. His office kept records on the farm, the mining, the laundry, construction, and repairs. ${ }^{35}$ The $W$ estoneer, the hospital newsletter, reported in September of 1955 that Mr. Alfred resigned and was replaced by Henry McKinney. ${ }^{36}$ Misappropriation of funds was a problem in many of the state institutions at that time. In 1957, the business manager at Colin Anderson, the state facility for mentally retarded children, was forced to buy overpriced and substandard quality food supplies. "Higher ups wanted the bills paid." ${ }^{37}$ This man's predecessor was convicted and was serving time in the state penitentiary. There was illegal purchasing and billing at other institutions as well. ${ }^{38}$

A change in government organization in the 1950s altered the way mental health institutions would be run in West Virginia. Since 1909 the politically run Board of Con-

The forensics building in 2008. It was constructed for the criminal mentally ill, then converted to an activities building, and later back to the forensics unit.

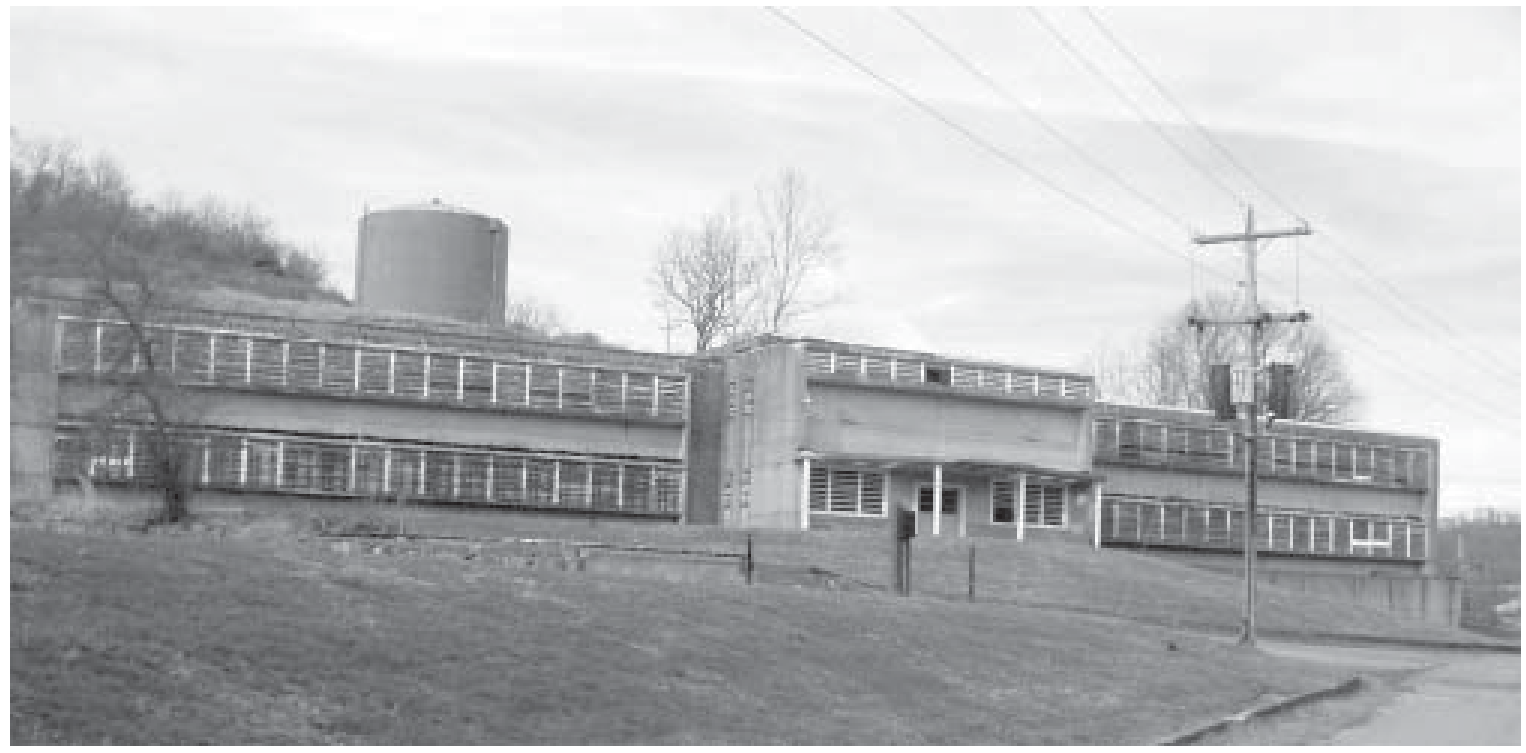


trol had supervised mental institutions, as well as educational, charitable, correctional and penal facilities. In 1957 the Department of Mental Health was created. The Board of Control members (three men who had been appointed by the governor and approved by the Senate for six-year terms) had rarely been physicians, had had little knowledge of medical or mental health affairs, and had resisted oversight by the Department of Health. They had not employed a staff to deal with medical problems and rehabilitation of patients. ${ }^{39}$ The Department of Mental Health would supervise the mental institutions and begin to implement change in the hospitals and in mental health care in general, with a shift to community care beginning in the 1960s.

\section{0s: The arrival of community care and the Alcohol Treatment Unit}

The 1960s brought important changes to Weston State Hospital. In many ways Dr. Mildred Bateman epitomized these changes. Dr. Bateman was appointed as the Director of the Department of Mental Health in 1962 and served for fifteen years. She had been clinical director and superintendent at Lakin State Hospital, and was the first woman and first African American to be a director of a state mental health department. She was described by Louise Gerrard, a historian, as "bringing full-time professional, non-political leadership to the Department of Mental Health." ${ }^{40}$ Under her term as director, many of the state hospital patients were released. The use of improved antipsychotic medications allowed more patients to be discharged into their communities, and this would be increasingly the case throughout the seventies, eighties, and nineties. Citizens of Weston were concerned because so many hospital patients were set up in apartments in downtown Weston. As Mrs. Haller remembered it:

The big upheaval came when that Mildred Bateman came in. Remember, she was a black woman, and a very, very brilliant woman I think. She's the one that came in and she turned all the patients loose and all this stuff. That's when the town was having a fit because patients were running all over town. [laughs] I mean she just emptied that hospital. She said they don't need to be in there; we can give them medicine. Well, then these people, you know, they had no places to go. ${ }^{41}$ 
Mrs. White remembered that the people of Weston were concerned because "suddenly there were state hospital patients all over town." A woman who worked with the patients came to a meeting of Mrs. White's church women's group. She explained to them how she was helping to set the patients up in these more independent living situations. She said the patients had to be taught such things as how to replace a roll of toilet paper. In the institution, that was something they had never done. ${ }^{42}$

The 1960s saw the beginning of community mental health centers in West Virginia. In 1962-63, the state wrote a comprehensive plan, funded by the federal government, for mental health programs. They conducted a study, questioning people all over the state as to their mental health needs. Educators expressed a need for services for emotionally disturbed children in schools and treatment for mentally retarded children. Sheriffs objected to the jailing of alcoholics. County court officials said that the elderly were being put in state mental hospitals because there was no way to care for them at home. An outcome of this comprehensive plan was to have counties take funds that they normally used to support people in state hospitals and put the money toward community mental health services. This was passed in 1965 and was the beginning of forty-seven community mental health programs in West Virginia. At the same time, the federal government passed the Community Mental Health Centers Act to construct community mental health centers. $^{43}$

Federal grants primarily emphasized community programs, but there was recognition that hospitals needed improving as well. The West Virginia legislature continued to resist paying higher salaries for physicians and thought that paying over $\$ 10,000$ a year was outrageous. ${ }^{44}$ The 1967 annual report of the Department of Mental Health stated that the 2,500 employees in the five West Virginia mental hospitals and Colin Anderson Center had received pay increases to meet a minimum wage of $\$ 3,000$ per year, the national poverty level. Most increases went to lower-paid workers who were averaging $\$ 205$ per month. ${ }^{45}$ The report also stated that federal aid had been made available for community services, hospital improvement projects, training grants, the VISTA (Volunteers in Service to America) program, and a Foster Grandparents' project. The latter was a federal grant to employ 152 foster grandparents to work with 208 mentally retarded and emotionally disturbed children at Colin Anderson, Lakin, and the Charleston Day Care Center. The 1967 report also stated that Medicare and Medicaid were added during this year. Three-fourths of the counties now had community mental health programs, and six out- 
patient clinics were established. Eight alcoholism information centers were set up along with new alcoholism treatment services at Weston and Huntington State Hospitals. There were 126 VISTA mental health volunteers serving in sixty-four community agencies and the state hospitals. The report also stated that the hospitals were overcrowded, and many patients suffered needless relapses as a result of a lack of services in their home communities. ${ }^{46}$

In 1965, amendments to Social Security Act made federal funds available for the care of older people in mental institutions. There were special requirements for Medicare beds. Hospital personnel had to be drawn from other parts of the facility to serve these geriatric wards, especially more registered nurses. So Medicare brought improved care for the elderly in state hospitals, but less care for other patients. There was still a need for more federal grants and more skilled employees. ${ }^{47}$

One area of the Weston hospital where a very active program was initiated in the 1960s was the ATU, or Alcohol Treatment Unit. This program was established in 1967, based on a successful one that had been set up at Spencer State Hospital. This unit was at times called the Alcohol and Substance Abuse Unit, also. The increase in the popular use of a variety of drugs in society in the 1960s, and the increase in awareness of the dangers of drug and alcohol usage, helped precipitate these kinds of programs. Of course alcoholism had been prevalent in society for generations, but the 1960s was a time when gov-

Garage and cannery, fruit rooms, 1919. West Virginia University Libraries

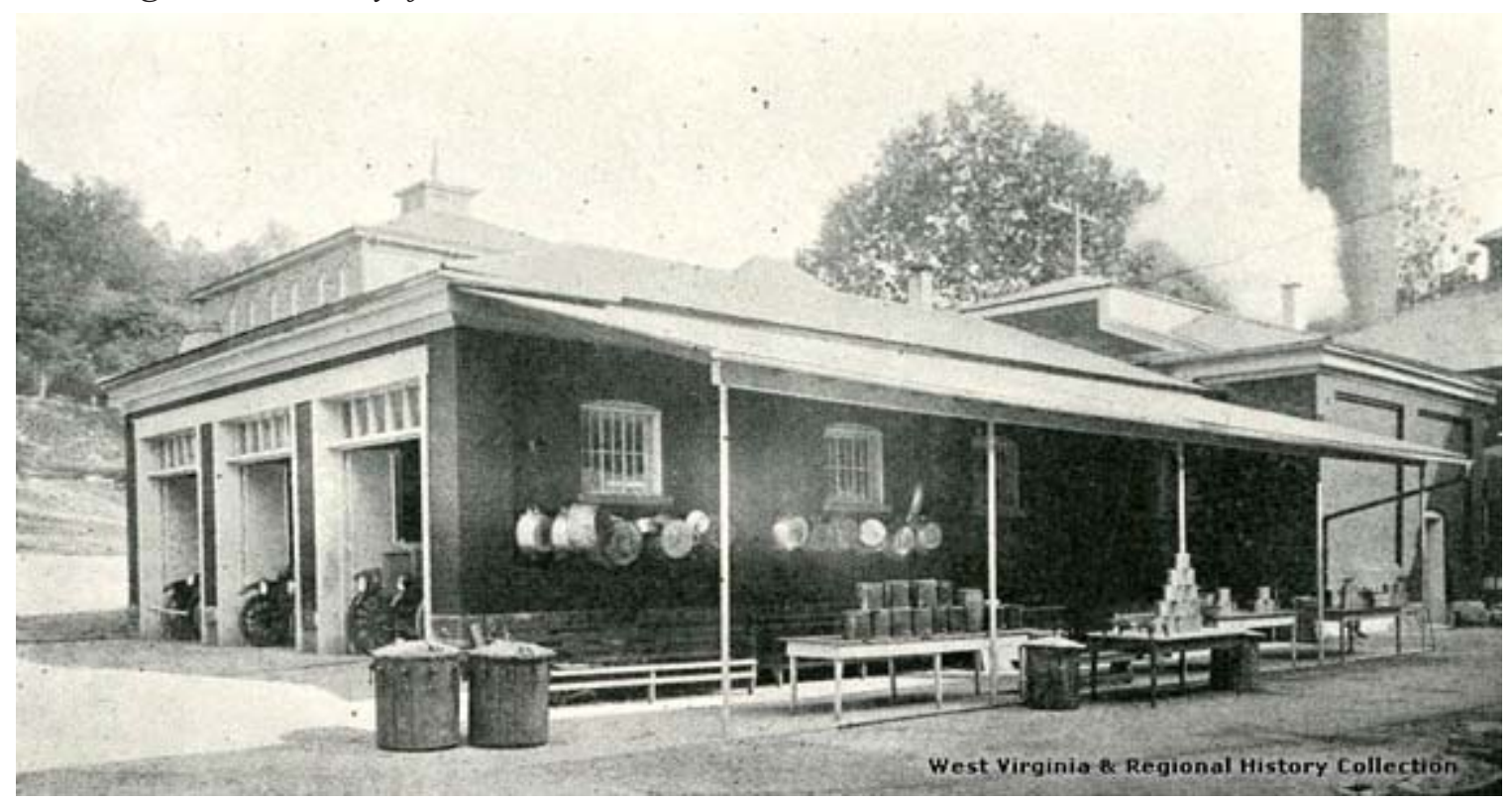


ernment decided become involved in trying to alleviate the problems caused by addictions. Karl Staubly worked in this unit at Weston from 1971 until it was phased out in 1993. As Mr. Staubly attested, "It wasn't warehousing. It was a pretty active program."

The patients in this unit first went through a detoxification period where they were gradually eased off the drug of their addiction. Patients were then involved in therapy sessions, both individual and group. Several classes were taught throughout the day on dealing with life issues and education about alcohol and substance abuse-including the physiology of the effects of alcohol and drugs on the various systems of the body. They would have films, lectures, and outside speakers to come in and talk to the patients. There was a full range of educational and occupational levels among the patients in this unitthey were not all homeless street people. Many of the people on the staff were in recovery themselves. Almost everyone on the staff had some connection to someone with abuse problems; a number of the women had alcoholic husbands. ${ }^{49}$

The patients in the Alcohol and Substance Abuse Unit had a variety of addictions, some caused by post-traumatic stress disorder from the Vietnam era. The addicted patients were also ones who had often lived in abusive situations. Mr. Staubly remarked that some of the women had suffered so from domestic abuse-one woman's face was covered with scars from her husband cutting her- that the women often had more bad memories and trauma than some of the men. The most common drugs seen in addiction at that time, besides alcohol, were cocaine and heroin. Some patients were there because of mari-

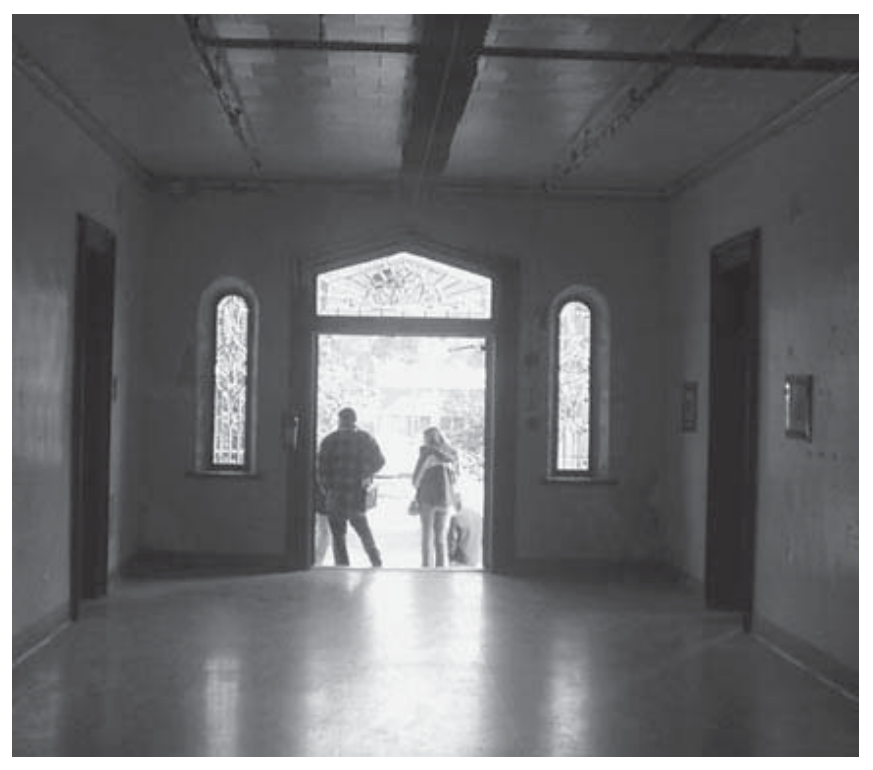

Entry into center

building, 2008. 
juana, but mainly over the legality issues, rather than it disrupting their lives as other drugs could do. ${ }^{50}$

An important part of the treatment in the ATU was to take the patients to local Alcoholics Anonymous or Narcotics Anonymous meetings and try to get them involved so they could continue to receive that support when they returned to their communities. Setting up support for the patients after they completed their program at the hospital was crucial. Some of the patients might need to live in a halfway house for a time. Another strategy to prepare them for discharge was to get the patients out into the community in other ways - the staff took them out for picnics at local parks and visits to state parks. They also incorporated an exercise program to try to help the patients feel better and improve their overall health. Mr. Staubly also noted:

Of course, so many of our people, because of what had happened to them during their active addiction, so many of them died rather young. You saw that in addiction. One person in particular lost an arm, had all kinds of problems in her background, and shethis is somebody I still keep in touch with—she's in very poor health. Several of the people we worked with were veterans who had had serious injuries in the military. So in addition to dealing with their addiction and continuing recovery, they had a lot of physical issues. ${ }^{51}$

The ATU program generally ran six to eight weeks. Sometimes people would be assigned there from the prison system for treatment, so they might be there longer and then return to prison to finish their sentences. Mr. Staubly thought this was helpful because their addictions were often the reason these people had committed a crime, or using and selling drugs might be their reason for being in prison..$^{52}$

Mr. Staubly sometimes felt that the Alcohol Treatment Unit was something of a "black sheep of the family" at the hospital. Their methods of treatment were different from what was being done in the rest of the institution. In the ATU, drugs were used to help addicted patients detox rather than have to go "cold turkey," but beyond that necessary use of medication, the program was intended to get drugs out of the lives of the patients. At the same time the rest of the hospital was relying heavily on the use of drugs to control mental illnesses. ${ }^{53}$ Moreover, substance abuse was a different kind of illness than what the other patients had, and some hospital staff viewed these patients differently. Mr. Staubly also said, "We were never that popular. I think the majority of the hospital was dealing with mental illness, and addiction was always something that they weren't really comfortable with, 
I think. I suppose they knew that maybe it was needed, but they really didn't—-that's one of the things I saw as a problem - is the conflict between alcohol and drug abuse programs and mental health in general. ${ }^{54}$

Bill, the security guard, expressed how he worried when substance abuse patients were sometimes put on wards with the other mental patients. He said:

There should have been a special place for the people that they brought off the street, you know, with drugs and alcohol. It was unfair to the patients to put them on the ward with them, and they burt patients on the ward, these people did. But they knew what they was doing. Once they got straightened up a little bit....yeah, they'd hurt - they'd take advantage of the actual patients. And I always thought that was so wrong. But what can you do? It's not like I didn't try. I was always fighting the system. People knew me well in Charleston, believe me..$^{55}$

With regard to substance abuse patients on the regular wards, Mr. Staubly mentioned that some patients would be given a dual diagnosis of mental illness and drug or alcohol abuse. Sometimes those people were housed on a regular unit, but might come over to the ATU for a day program. He thought it was sometimes difficult for the staff to work out whether a person's problems were from mental illness or to what degree they were due to substance abuse..$^{56}$

The ATU was, for a time, housed in the oldest part of the main building. But even there Mr. Staubly reported that the building was clean and well maintained. The ATU was moved to different locations from time to time, as were most of the units, and he remembered patients finding little nooks and crannies to hide items in, such as liquor. One patient, one of their more colorful characters, was trying to grow his own "magic mushrooms" back in a cubbyhole. ${ }^{57}$

Mr. Staubly said maintaining a sense of humor was important in their unit, and recalled how they realized that many of their clients were not honest with them. He shared a joke the ATU staff had: "How can you tell if an alcoholic is lying to you?'——_If his lips are moving.' [laughs] In other words, they always are." ${ }^{.58}$ 
The hospital grounds in the 1970s.

Contributed by Karl Staubly, alcohol and substance abuse counselor, 1971-1993.

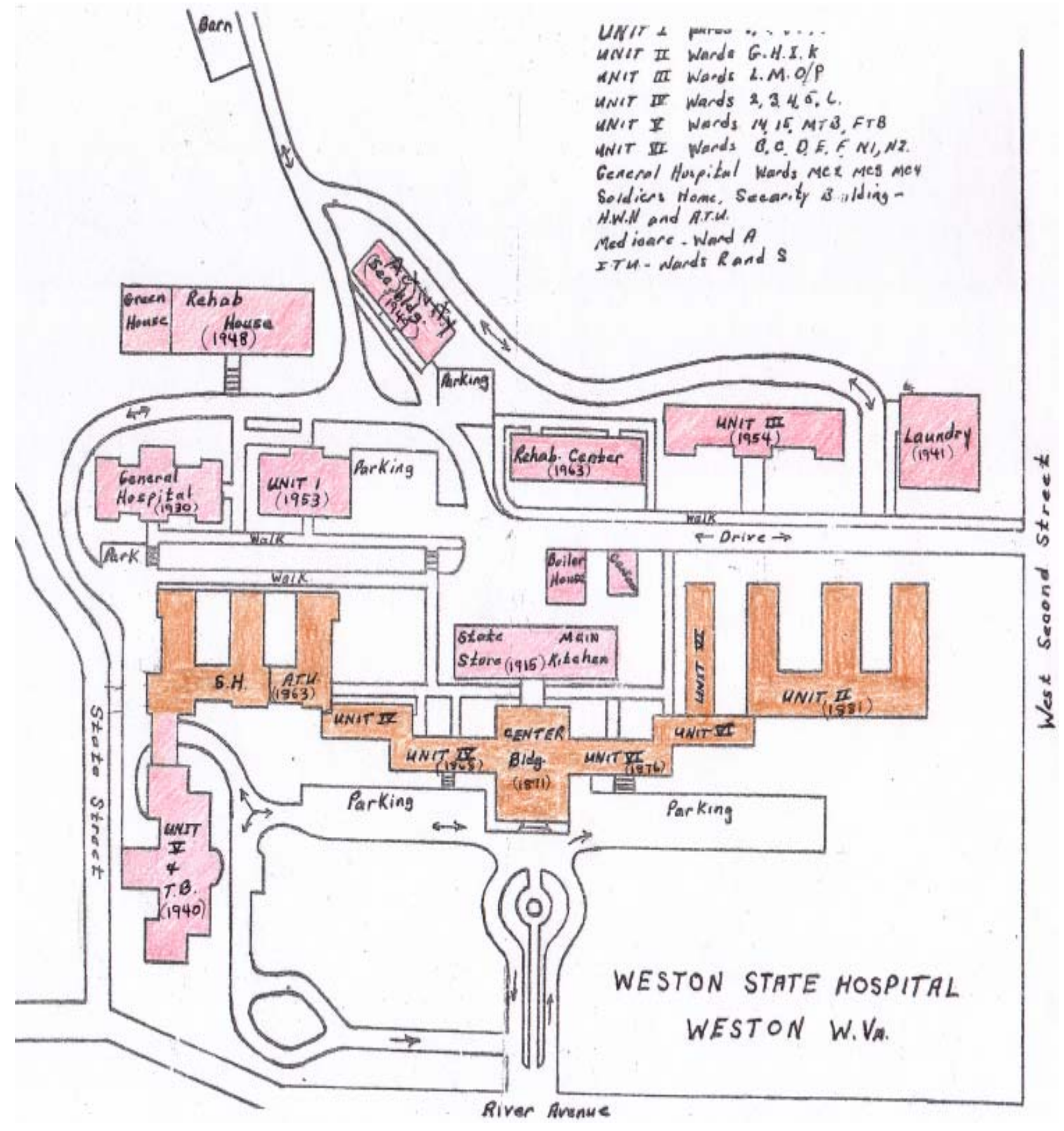




\section{0s and 1980s: Drug treatment and increasing patients' rights}

The 1970s and 1980s were to see major declines in patient population at Weston. Medications to control mental illness were the main method of treatment, and were sometimes overused. Professional staff, particularly registered nurses, were always in short supply. Even in the 1980s there were only about twenty registered nurses, with four assigned to the evening shift and only one on the night shift. Ms. Mason, an RN at Weston from 1979 to 1990, recalled that LPNs were able to give medications and injections at that time, which took some of the stress off of the RNs. ${ }^{59}$ Bill, the security guard, was surprised at how few guards there were when he began work, only two per shift in the 1970s. He and his supervisor wrote to the state government asking for more security guards, but the most that were ever on duty were four per shift. ${ }^{60}$

Some of the most vital hospital employees were the health service workers, or aides. Many superintendents and physicians at mental hospitals emphasized the important role played by the aides, or attendants. A physician would see a patient only occasionally, but attendants were constantly in their presence. Richard Lael noted, in writing about the Fulton State Hospital in Missouri, "It was the attendant who soothed troubled patients, who helped them put on their clothes, who helped bathe them, who engaged them in conversation, and who kept them neat throughout the day." "' In his study of state mental institutions, anthropologist Richard Salisbury noted that "custodial care" ought not be disparaged. Those who worked in such hospitals should not be made to feel that their work was not respectable. ${ }^{2}$ Salisbury spent a year studying a ward in a mental institution in California in the 1960s. He reported that aides often had insight into a patient's abilities or limitations of which the doctor was unaware. Doctors seemed respectful of the attendant's opinions, and nine times out of ten would do what the aide suggested — such as urging that a patient be given a job since he had been doing well on the ward. One time an attendant explained to a doctor that a quiet patient who had just been transferred to his ward would not manage well there-he would be beaten up by other patients. The doctor took his advice and transferred the patient to a

quieter ward. The attendant later said, "It's hard to have to tell the doctor he is wrong, but he really doesn't know what it is like on Ward A." ${ }^{63}$

Despite the important role aides played, they were not well paid. Employee pay at the hospital was minimal. The average salary for all employees even by the 1990 s was 
$\$ 16,000$ a year, and that included the physicians' salaries, who were making approximately sixty to seventy thousand a year. A quarter of the staff was eligible for food stamps. ${ }^{64}$ All the employees interviewed agreed that they were not paid much. Mrs. Lowther was paid $\$ 250$ a month when she began work at the hospital in $1968 .{ }^{65}$ Several expressed that they received low pay, and for hard work. The employees were eligible for benefits such as health insurance and retirement plans.

The hospital employees sometimes had to work more than their forty-hour week. Mr. Staubly and other staff members took turns being present on weekends in the Alcohol Treatment Unit. They often accompanied patients to community Alcoholics Anonymous or Narcotics Anonymous meetings in the evenings, which they considered a very important part of patient recovery. ${ }^{66}$ Thom Haller and other recreation employees supervised the dances for the patients in the evenings. ${ }^{67}$ Employees received comp time for their extra hours. Dr. Michael Todt, an administrator at Weston in the 1990s, remembered that in the final years of the hospital many people were being compensated monetarily for overtime, and it was necessary to do away with that in order to live within their budget. ${ }^{68}$

The physicians at the hospital through the 1970s and 1980s were almost entirely foreign, most from Asian nations. Many of these foreign physicians had heavy accents and were difficult to understand. The nurses learned to understand them and acted as interpreters to the aides and patients. Ms. Mason, the RN, remembered:

There was an Indian doctor there when I first started, and we had trouble with a patient, so I called her. And she said, "Well, give him waaaallum." And I said, "Doctor, I'm sorry, but I don't understand you." And after she repeated it the third time, she was mad at me. And I said, "Well, maybe you could spell it." And she said, "V... A..." And I said, "Oh, you mean Valium." But you couldn't understand the doctors. Oh, it was terrible. ${ }^{69}$

Dr. Charles Chong, one of the physicians who was highly spoken of by employees in these interviews, worked at the hospital two years and resigned in 1980. In an interview with the Charleston Gazette, he criticized the other doctors at the hospital. He said that some of the physicians documented physical and mental exams of patients that they had never performed. Some had treated patients without examining them, including treatment with major tranquilizers. He saw language barriers as a problem, particularly as physicians attempted to evaluate mental illness in the patients. Dr. Chong had proposed 
changes to his superiors, but was ignored. His opinion was that the administrators at the hospital "were selected for their low profile and harmlessness. They are put in charge of running things and do not make any waves." ${ }^{\text {70 }}$ The superintendent of Weston at the time, Arthur Paletti, responded to Chong's remarks by saying that Chong had good ideas, but unrealistic ones. "He is a very idealistic fellow. I wish everything he conceived of could be done." ${ }^{ग 11}$ Mr. Paletti explained that it was very hard to attract physicians to a rural mental hospital that held so many chronic patients. He added that the hospital could not be run without the foreign-born physicians willing to take these positions. In 1980, physicians were being offered $\$ 50,000$ a year at Weston. Paletti acknowledged, however, that treatment of patients was more difficult because of the physicians not having a full grasp of the English language. ${ }^{72}$

Working at Weston State Hospital could be a highly stressful for all the employees. The housekeeper said when she first began work there in the mid-1970s, she was not sure if she would be able to do it. She worked in some of the difficult, locked wards. After a time she adjusted, and it just became a normal workday. She expressed that she wished there had been counseling available for her after a murder that happened on one of her wards, because she was truly disturbed and did not want to go to work for some time after that. The patient, a man who had been hung by two other patients, was someone she had truly liked. ${ }^{73}$ Mrs. Lowther, the aide, mentioned that the work was really difficult in the early years, and she was uncomfortable with the perception of those outside the hospital that it was an awful place. People were either afraid of the hospital or made fun of it. ${ }^{74}$

Bill, a security guard, said the physical challenges of working as a security guard took a toll on him over the years. By the time he was in his late forties, he had suffered so many injuries that he needed to transfer to a physically easier position. He laughed about some of the older security guards who had worked with him when he was younger. There was one who, when they saw trouble was developing, would say, "I'll hold your hat, Bill, and give me your radio." This man was content to be an observer. Bill explained that in the later years the hospital developed a crisis team of aides trained to come and help whenever there was trouble anywhere in the hospital. That took a lot of the pressure off of the security guards. Bill expressed that he never really had any fear for his life, though there were a few times when he realized he could have been seriously hurt. He said he worried more about hurting someone else, but believed he had never hurt a patient. ${ }^{75}$ 
Mr. Haller, who worked with the recreation department in the 1970a, told about a particular patient that he remembered who is an example of one who probably strained the patience of the aides. Her name was Linda Lou and she liked to talk-a lot. He would play checkers with her, and he could still describe how she spoke:

She would tell you about herself, and she'd say, "I'm Linda Lou Sixteen, today thirty-one!" Which we felt meant when she was sixteen somebody had taught her that she was 16 and then when she was 31, somebody had taught her that, no, Linda Lou, you're 31. "Sixteen, today thirty-one!" She'd typically say that. "Hot out; it's cold." 'That was something else she'd say. And then sometimes she'd go off and Bernie, this other woman — she was fun, too-who we worked with, because I remember her turning to Bernie once and saying, [rather loud and very fast] "She's a big woman! She's a big woman! Where'd you get that big woman at? Sears Store? Sears Store? Sears Store? Keysertown. Keysertown. Keysertown Mall! How much she cost you?" [laughs]

So I would sit there — and she called me "lover boy" — so, you know, I paid attention to it. [loud and fast]"Hey, lover boy, we gonna play checkers?! Gonna play checkers today?! Gonna play checkers on the ward! Checkers on the ward! Checkers on the ward with Linda Lou! Checkers! Sixteen, today thirty-one."

She'd just go constantly all afternoon. Bla bla bla bla bla bla bla bla bla. All day long. "It's hot out; it's cold. It's that woman! She's a big woman! Where'd you get that woman at? Sears Store? Sears Store? Keysertown. Keysertown, Keysertown Mall? How much she cost you? Two cents. Two cents. Two cents. Two cents. Two cents. Two cents. How much she cost you? Two cents? Uummmm.” It seemed like every now and then she'd go through a kind of a break and go "Uummmm." [laughs]

Then she'd like - as her attention would be drawn to different things.... "Color a page! Color a page! Color a page! Let's color a page! Color a page on the ward! Color a page with Linda Lou!"

But she was joyous. So, yes, she was insane and she made everybody crasy, but she was just like-like there was this woman-really one of the most scary humans that I've encountered, was this woman on that ward that would sometimes come in. And then people would be grabbing her to take her back 'cause she was like, sort of big and scary and she liked to roll feces in her fingers, and she'd be naked typically, and she'd be like_- "aaaayaaahhhh" so they'd kind of drag her out. And, you know, Linda Lou would be like, "Whatever! It's home!" [laughs] It wouldn't bug her at all. So there was this scary person, and Linda Lou was, "Oh, whatever!"76 
Mr. Haller really enjoyed Linda Lou, but one can imagine what a challenge it must have been for the attendants who had to care for her all day, or why she was too much for her family to manage. So that was a different kind of stress, not from a person who was dangerous, but from a person who required patience.

Another source of stress that several employees mentioned was from dealing with administration or "the system." Sometimes they were troubled by something done by an immediate supervisor, and sometimes it might be some action by the government in Charleston. The housekeeper remembered a story:

We had one patient there- - he was a pretty nice guy. I mean he didn't cause a lot of trouble, but he was a younger-like guy. He was probably in his twenties. He was from Clarksburg. I can't remember his name, either. But he got up this one morning, he got his clothes on, took his medication, had breakfast, got all cleaned up, went outside and jumped right smack in front of a milk truck. Killed him. That guy, that driver of that truck, he was just devastated—he just felt awful. Just walked right smack in front of him. Yep, just like it was meant to be. It was right there at the arts and crafts building. In the back way, right there along the side of the road. And of course there was blood and stuff after the ambulance come and got him and everything and took him. Our boss, he didn't have sense. "All right, Calvin," he said, "Go get the water hose. Get that mess cleaned up." Just, God, like it was just an animal, just like it was nothing. God, I thought, is that all that man's life meant? Just—is that all it meant? It was anful. ${ }^{77}$

This woman also expressed frustration at the design of the new Sharpe Hospital. She and the other housekeepers knew that they should not install metal towel racks, and later a patient tore one off a wall, broke it, and cut his throat with it. "They should never have put metal towel racks in," she said, "But you couldn't tell people nothing. Wehousekeeping - we couldn't tell them. They wouldn't listen to us, but we knew."”78

Ms. Mason, the RN, expressed frustration with the government in Charleston, and said she was upset to see waste by the government. She said when new furniture was purchased, for a waiting room for instance, they would not try to sell the old furniture, which was still usable. Instead, it was just hauled to the dump. ${ }^{79}$ She also said the people in state government were trying to govern from afar and did not really grasp what the situation was at Weston. At one point the government decided to save money by having no security guards on duty at night. Ms. Mason thought that was poor judgment, because some of the 
employees had been having their tires slashed at night, even when there were guards on duty. ${ }^{80}$

Another problem at the hospital that Ms. Mason commented on was that some of the aides on the night shift slept on the job. She laughed at how they would call ahead to the next ward to warn them that she was coming around. However, she worried that the patients might need help, have a seizure, etc. and needed alert attendants. ${ }^{81}$ One time she found a female patient who had slid down in her waist restraints and was in danger of choking while the attendants had been asleep. She was furious with them. "I blew my top at those two. They got mad at me, but I said, 'You know I have to report this. I'm going to write you up, and I hope you get two or three nights off. You'll get caught up on your sleep!"”82

Some of the employees also mentioned that things were stolen from the hospital. One said that small items like butter went out, but you could hardly blame the poorly paid employees. Another said that right before the closing of the hospital, the "higher ups" were taking the antique furniture out of the attic — it was being loaded up in trucks. The rumor was that it was to be sold in New York City, but Dr. Todt said he was unaware of furniture stored in the attic, and that if it was moved the state did so without his knowledge. He said extra furniture would have been taken to the new hospital or put in storage in Charleston. He added, "However, when I got to the hospital in 1992, there was a major problem with stealing state property. So, who knows?" 83 There were rumors that a large amount of bedding went to a private nursing facility and that even shirts were stolen, presumably before being stamped with the hospital identification. A few employees discussed the restrictions put on employees to prevent stealing. One told about an LPN who needed to go to the cafeteria one night to get bread and peanut butter to make sandwiches for some of the mentally retarded patients. She had to take along another employee as a witness that she took just one loaf of bread. (The rest of the story was that some rats scurried away when they turned on the lights - though no other employees mentioned any animal problems other than the skunks that Ms. Mason, the RN, used to see at night when she was going from building to building - she said you just left them alone.) In another story, Ms. Mason had mentioned being required to have another employee with her as a witness when she went to get some medication, if it was a narcotic. ${ }^{84}$

By 1981, the main building at Weston was one hundred years old. Part of the south wing had been remodeled in the 1930s after the fire, and several additional buildings had 
been constructed on the grounds in the 1940s and 1950s. All of these employees remembered the buildings as being kept quite clean and well maintained, though they were old. The cleanliness had improved greatly since the Gazette articles of 1949 had described conditions at the hospital. The housekeeper said she knew another housekeeper who had begun working in the 1960s in the medical center building, and she had described how filthy and odorous it was when she began working there. She could smell the building as she approached it, and thick dirt was built up in the corners of the rooms. But then in the 1970s the hospital began to hire more housekeepers, until there was a staff of thirty or more. These housekeepers improved conditions greatly compared to those decrepit conditions described in the late 1940s. Temperature regulation was a problem in the buildings. Dr. Todt told how one summer they had to go out and purchase every fan in Weston trying to keep the wards cool in the stone and brick buildings. Patients who were on psychotropic medications were in danger when it could reach 95 to 100 degrees up on some of the wards. ${ }^{85}$

So the general consensus of the employees was that the facilities were old, but clean and maintained, for the most part, in the last few decades of the hospital's existence. They were doing their best with what they had. Tunnels ran underneath, connecting several of the buildings. These were left from the old steam heat system coming from the boiler plant. Mrs. Lowther said she saw tunnels when she had to go to the basement with the laundry, but she would never dare venture into one. ${ }^{86}$ As Ms. Mason, the RN, described, "At that time the buildings were in good shape. You had the housekeeping. They cleanedeverything was nice and clean. And then a lot of the times the patients that were better, they would want to mop and help clean. I thought it was-I mean it was old — but I didn't think it was in that bad of shape. ${ }^{\prime 87}$ Most of the employees mentioned that the dietary department prepared food that was reasonably good and nutritious at the hospital. The dietary staff would provide good food when groups went out on trips to parks and all, as well. One employee noted that they did not always plan out their year well, though — the food was quite good as they began their fiscal year in July, but after February they were often eating a lot of rice.

Most of these employees expressed concern over the heavy use of medications at the hospital at this time. Certainly the drugs calmed many of the patients who might be distraught and helped stabilize some who had the most serious mental illnesses, but they were probably over-prescribed. Mr. Haller, rec department worker, suggested that the biggest 
problem at the hospital in the 1970s was the strength of the medications being given to patients. He remembered what a potent, tranquilizing drug Thorazine was, which was used quite liberally at that time. Patients who were on Thorazine were subject to having their skin burn very easily in the sunshine, so part of Mr. Haller's job was to go around and get people who were sitting in the sun to come into the rec hall. Mr. Haller said:

So we were always encouraging the drugged outside sitters to go and be a drugged inside sitter. So it was a very powerful drug, and so-was it a good drug? I don't know. It was part of the institutional culture, part of the strategy for care, especially for the people who maybe would be violent. So this woman, Mary, was on it. I don't understand why she would need to be on it, other than that she probably made people crazy because she was very high strung, so she would want to talk to them all the time or whatever. I don't know. So, there could be some, "Oh, you're making me crazy, let me give you this little tranquilizer," or, "Mary's making us absolutely insane, so let's just sedate her." So I suspect there was some of that. ${ }^{88}$

Methods of managing patient behavior other than the use of drugs, or in addition to the use of drugs, was always a concern of all who worked at the hospital. Good patient behavior was rewarded with a grounds pass. A doctor began this policy by first issuing a one-half hour pass. If the patient were well behaved, then the time that he was allowed to be off of the ward would be lengthened. Many patients had considerable freedom on the grounds of the hospital in the last few decades. A few patients also had town passes. Some who had money would go over and shop in town. On the other hand, improper behavior could result in a patient having their pass pulled.

All the employees discussed learning how to gain cooperation from the patients by speaking gently. Ms. Mason, the nurse, noted that eighty percent of the battle was in handling them well. She had to be firm, but kind, to gain cooperation. She and Dr. Todt both discussed how it was counterproductive to speak too harshly or loudly to a patient. They would then be unlikely to do what you had asked. ${ }^{89}$ When patients became upset, all employees had to learn how to "talk them down."

If patients became violent or uncontrollable, restraints or seclusion might have to be used. In the sixties, aides were able to send a patient into a seclusion room and leave them there as long as they wished. In later years the staff could put a person in seclusion only for an hour. Then they had to have orders from a physician to be allowed to keep them there, and the aides had to check the room every fifteen minutes. In the most recent years, Mrs. 
Lowther, the aide, reported that a person in seclusion had to monitored constantly. One aide had to watch them and write down what they were doing every five minutes. This was to prevent suicide and also to prevent an aide from having someone put into seclusion just because they had "looked at the aide cross-eyed." ${ }^{\circ}$ Dr. Todt remembered how they tried to train staff to deal with upset patients:

Well, how do we deal with patients? How do we re-direct them? How do we talk them down instead of getting them to be violent? My sense was if the patient was that violent, then they were really distraught and upset. And also, what got them to that point? Because patients - some patients - do just go off because of the nature of being mentally ill, but a lot of patients were egged into it. The staff just did not know how to communicate with them. So we provided, began to provide, training in terms of how to talk effectively with a patient. You know, if I said [loudly], "Well, Kim, just move!" Well, what's a patient going to do? They might get upset with that. They might move, but they'll get upset. "No, I'm not gonna move." "You move, or I'm gonna restrain you!" Well, there's the confrontation. So we would train, how do we more effectively communicate so we didn't have that? The staff got hurt. We had a high numbers of cases of workman's comp, the staff getting burtin these cases. ${ }^{91}$

Throughout the history of the hospital, some of the patients worked alongside the staff. In the last decades at Weston, several patients received a small amount of pay from the state for their work. Others assisted informally and were rewarded with a coke or cigarettes or some change that they could spend at the canteen. Mrs. Lowther, the aide, said that in the early days, the sixties and seventies, if they had not had the patients' help with cleaning on the wards, they could not have managed all their work. They helped make beds, helped bathe patients, and helped sweep and mop. The floors had to be swept and mopped on every shift. She thought that in the seventies the patients received pay of two or three dollars a month for assisting, and that now at Sharpe Hospital they receive minimum wage. Mrs. Lowther reported that patients would become quite upset if they were not allowed to work. They enjoyed it and it made their day better. ${ }^{92}$ Patients also worked in the greenhouse and grew flowers, including beautiful Christmas poinsettias. ${ }^{93}$

Mr. Haller remembered a patient who helped in the rec hall. He did a lot of the cleaning and was there every day. Mr. Haller noted that this man once explained to him his reason for often holding his fingers in his ears. "The reason he holds his fingers in his ears is so the water in his ears will run down into his throat. If he removes the fingers from his 
ears, the wind will go through his head, the water will evaporate, rise, and give him a headache." 94

The housekeeper said that a patient named Sam, a veteran, helped them with sweeping, taking out trash, and doing other chores. He was happy to do it for fifty cents or a cigarette or a bottle of pop. She told another story of a helpful patient:

One time we had this one, Clarence-he was mean. Big black guy, and he was mean. He used to be the famous one that was so mean up there for so many years? Well, if you ever hear of the name, you'll know. Well, he was pretty good to help on the ward. Well, he come to the door, and told the guy I worked with, he said, "If you'll go down to the laundry room and get me some sheets," he said, "I'll do the beds up this morning." It was bed day. My partner said OK, you know, we'd done it before. Nobody ever said anything, or it was fine. He'd go on and do the beds. But he tied all those sheets together and went out the window and fell and broke his ankle! [laughs]

We would have [been in trouble], but we lied out of it! [laughs] The nurse come back there and wanted to know if we'd give Clarence sheets. "Why, my lord, no. We didn't give anybody sheets!" But we had, we'd gave him them sheets. I told my partner, I said, "If you'd have gave him two more he'd have had enough to got to the ground." [laughs] I said, "You didn't give him enough sheets." But he tied all those together and went out the window. On third floor! Yes, sir, we were on third floor. ${ }^{95}$

By the last two decades of the hospital's existence, having people admitted to a mental institution became more difficult. They had to be proven a danger to themselves or others. A person would be taken before the mental hygiene commissioner in their county. A physician, psychiatrist, or psychologist would evaluate the person, and a determination would be made as to whether they were an active danger to themselves or others. When admitted to Weston in the last decade, the patient would be evaluated after three days, ten days, and thirty days. After any of those assessments, they could be sent home. Many of the patients by that time were ones suffering from schizophrenia and bipolar disorder. ${ }^{96}$

The 1976 annual report of the Department of Mental Health discussed changes at Weston. The hospital was strengthening ties with community mental health centers-Valley Mental Health in Morgantown, Central District Community Mental Health in Clarksburg, and Appalachian Mental Health Center in Elkins. The purpose of this cooperation was to improve the success rate of community placements. A "halfway house" for 
View from a third floor window.

Clarence must have really wanted to leave.

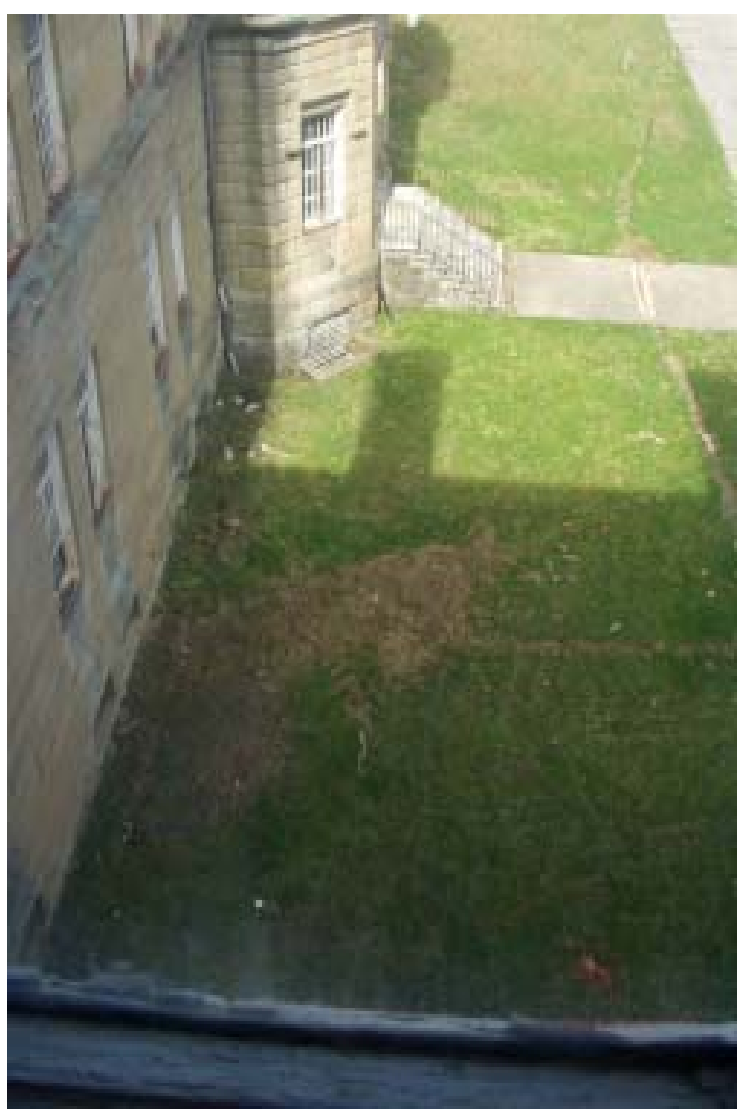

rehabilitation was operating on the hospital grounds in a building originally built for employee housing. It housed twenty residents who were candidates for community placement. Some of these residents worked part time in the community and therefore had some money and some exposure to the community. There was a day care program for a small group of mentally retarded adults, and an adolescent unit for a "backlog of mild to moderate retardates continued in operation while awaiting suitable placements." The Behavior Therapy Unit was operating for "holdover resident patients who are awaiting community placements. ${ }^{97}$ One decade later, in 1986, the breakdown of patients remaining at the hospital was listed as ninety mentally retarded, sixty in the Alcohol Treatment Unit, seventy-eight elderly, and one hundred twenty-five adult psychiatric care patients. This totaled 353 patients. $^{98}$

Very important changes happened in West Virginia after the Hartley and Medley cases in the early 1980s. A public interest attorney in Charleston, Dan Hedges, had filed class action lawsuits to demand high quality care for patients in state mental hospitals and other mental health facilities. Patients were to be sent home from the state mental hospitals if at all possible, so thousands of patients left institutions in West Virginia. As a result of the 
Hartley and Medley rulings, advocates for the patients were placed in the hospital at Weston and other mental health facilities. So whenever a patient felt that his rights were being abused, he could go to an advocate and the advocate would investigate the complaint. These advocates were managed by the Legal Aid Society and were funded by the state. When he began his work helping manage Weston, Dr. Todt recognized the need for change and for advocates to assist the patients. He said, "There was abuse by the staff toward the patients. I would say ninety percent of the staff were wonderful - they were caring, giving, trying to do the very best, but they didn't have any support. They didn't have psychiatrists; they didn't have social workers. There was no treatment on the units" ${ }^{\prime 99}$ He could see the need for an advocate program and knew that reform in patient treatment was necessary.

An increasing awareness of the rights of mental patients was an important development in the 1980s. Mental patients who could manage in the community with supervision or in a group home were to be released from institutions. The ones remaining in state hospitals were to be receiving active care, not just custodial care. Patients were to be helped to return to the community and more independent living. One former patient sued Weston State Hospital for his lack of treatment and training while a resident there. In the 1980s, a patient from Fairmont sued four physicians at Weston for his having received no vocational training. He was described as borderline mentally retarded and had been institutionalized from age five to twenty-one, with the last five years spent at Weston. He was released in 1977 . He had sued for $\$ 4.5$ million and was awarded $\$ 300,000$. He had received only minimal special education training and no vocational training at the hospital. The physicians were charged with medical malpractice and violation of state law "requiring reasonable and humane care and treatment for patients in state mental institutions." 100 His award was to be placed in a trust fund to be used for training and counseling.

So several factors came together to spur the move toward deinstitutionalization. The availability of more psychiatric drugs helped patients leave the hospitals. Increased federal funding for community mental health programs caused states to begin to emphasize community care. Medicaid provided health care to the poor and disabled; it typically would not pay for patients in psychiatric hospitals, but once they were released into the community, most former patients qualified for Medicaid. The development of more forprofit nursing homes with federal funding available provided alternatives to state institutions for the elderly. The growing public and professional disapproval of mental institutions, as criticisms of custodial care increased, pressured state governments to look for 
change. The Supreme Court and other legal decisions that "mandated treatment of patients in state hospitals while restricting admissions" was another factor. ${ }^{101}$ Patients continued to be discharged from Weston and other state hospitals.

\section{0s: Improving quality of care and closing the hospital}

By the 1990s major changes were underway at Weston. The transfer of patients to community life continued as preparations were made to close Weston and move to the new, smaller, Sharpe Hospital. The decision to build a new hospital had been made because the Weston Hospital was so old and would have been too expensive to renovate. When Dr. Todt arrived to help manage the institution in 1992, they needed to get the hospital accredited under the Joint Commission on the Accreditation of Hospitals in order to begin receiving federal assistance in the form of Medicare for the patients and to be approved for private insurance. Long term nursing care facilities like Hopemont were eligible for Medicaid funds as well. In this way the federal government could help support what had been a state government expense. For every dollar that the state of West Virginia put up, the federal government would give three, and as Dr. Todt said, "That's a great way to fund your hospital." 102 Patients at Weston were not eligible for Medicaid while in the hospital, but could receive it when they were released. In the late 1980s, the state had shifted most of its mental health money into Medicaid through the community mental health programs and through facilities for the elderly, and thereby received more federal assistance. However, accreditation under the Joint Commission was sought by the hospital not solely to acquire funding. Striving to meet strict standards of care by seeking this JCHOA accreditation would also improve the quality of care for the patients at the hospital. The hospital would have to follow very strict standards with regard to the physical facilities as well as the patient care in order to meet accreditation. ${ }^{103}$

In 1992, a patient committed suicide at Weston, and then another patient was murdered (this was the second murder, they suspected, by a patient who was known to have murdered another patient a few years prior to this). The patient advocates were demanding change, and as a result, the administrator, Rein Valdov, and the medical director, Cal Sumner, were replaced. The state decided to hire the Ramsey Corporation, which ran Chestnut Ridge Hospital in Morgantown (before it became part of WVU) to administer the Weston Hospital. Gordon Steinhaur, the CEO of Chestnut Ridge, became the Ad- 
ministrator at Weston; Michael Todt, the Director of Clinical Support Services; and Pat Haynes, the Medical Director. The Weston Democrat newspaper reported on the removal of Rein Valdov as the administrator after the deaths of two patients at the hospital. He had been at Weston since 1984, was described as "a popular administrator," and was being transferred to a position in the Department of Health and Human Services in Charleston. The Democrat described Valdov's farewell address to the hospital employees as he prepared to leave. His voice had choked with emotion several times while addressing them, and he had received a standing ovation at the conclusion of his remarks. Following the meeting he was greeted and hugged by many staff members, many with tears in their eyes. Valdov was being replaced after the death of 45-year-old George Bodie, who died on September 28. There were reports that another patient was involved in the death, but no criminal charges had been filed. The article reported that the new plan of administering Weston Hospital would cost an additional \$466,000 in management and physician services. ${ }^{104}$

Dr. Todt reported that Rein Valdov was a very capable administrator, but was replaced in order to satisfy the advocates, who were demanding change after the two hospital deaths. ${ }^{105}$ One of the two hospital deaths was a suicide, and the other a suspected

\section{Hospital greenhouse in 1919.}

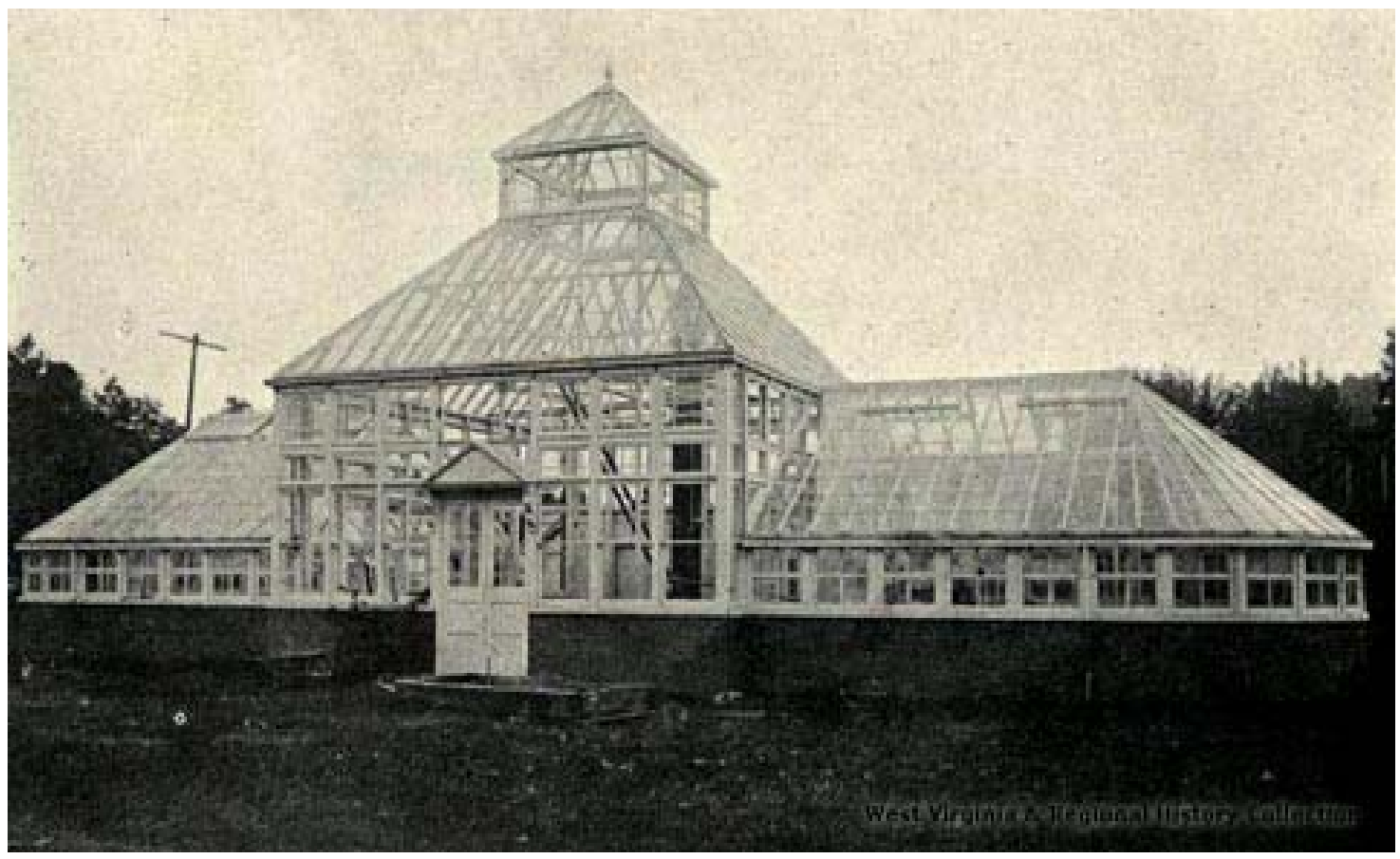


smothering of one patient by another patient. ${ }^{106}$ The Weston Democrat ran an editorial denouncing the removal of Valdov as "an outrage." Valdov was described as a "likeable, hard-working administrator who took a hands-on approach to the seemingly never-ending job of overseeing an outdated facility." ${ }^{107}$ The article admitted there were problems at the hospital, but argued that there had always been and would always be problems, no matter who was in charge. It stated that Valdov had battled, on a day-to-day basis, for the betterment of hospital clients." 108

Soon after this new administration took over, a newly released patient threw acid in a policeman's face in Wheeling, and the hospital was sued. Dr. Todt was responsible for looking into what kind of treatment this man had been given, and what he discovered was that the only treatment being offered at the hospital at that time was drugs, administered by people who were not psychiatrists. The physicians working at Weston had years of experience with patients, but they were not being supervised. He reported, "They were doing the best job they could. They really were doing the best job they could, but they weren't being supervised. Treatment records weren't being scrutinized by the only psychiatrist there." ${ }^{109}$ Dr. Todt began to work on improving clinical support because he believed that what David Sudbeck, the court appointed monitor, wanted for the hospital patients was truly needed because, as he said, "The care there left a lot to be desired." Individual and group therapy was not happening, social workers were just placing people in the community, and the recreation department was not preparing people leave the hospital and be functional in society. Treatment plans had to be developed because the Joint Commission and Medicare would be coming into the hospital and looking at what the psychiatrists were doing, what the psychologists were doing, what the social workers were doing, and what training the patients were being provided. ${ }^{110}$ When Dr. Todt looked into the patients' treatment plans, he saw there was little but medication being offered. In addition, community mental health centers were facing budget cuts, so there was not enough staff to follow up on the care of those who had been released from the hospital. If the discharged patients did not show up for therapy or medications, they were "lost in the cracks." 111 So there were many challenges facing the mental health system at that time.

The most serious problem was the need for more therapy and treatment for the patients. Lack of adequate funding was another problem. Federal funding, which was mostly directed to community mental health centers, was being cut in the late eighties and nineties. Dr. Todt said: 
One of the things we figured out early on is that mentally ill patients don't get a lot of money because-two reasons. One is people think very poorly of them, and second, people believe that it's an intractable disorder-there is nothing you can do about it. A lot of money goes to education because children are the future of our country, and you can change children. Money doesn't come to the mentally ill because they're the panhandlers on the street, and [they think] there's nothing you can do about mental illness anyway, all you can do is treat it with drugs... There was really a major lack of funding, not only in this state, but in all the other states. ${ }^{112}$

Mr. Staubly, from the Alcohol Treatment Unit, said something similar. After the ATU was closed at Weston in 1993, Mr. Staubly worked for Summit Center in Clarksburg, a community mental health center that served three counties. Summit Center was downsized twice, partly because of cutbacks in federal support. Mr. Staubly said, "There's a stigma to mental health and certainly to addictions, and I think it's the thing that will be reduced first, rather than supported. They certainly want to fight heart disease and cancer and so on, but I don't think it's quite as popular to deal with mental health."113

Until 1992, there had been at best one psychiatrist on the staff at Weston State Hospital, and the other physicians were family practitioners, internists, or others. Dr. Todt described the doctors as "competent physicians who had had years of experience working with patients, doing the best they could, but they were not psychiatrists." 114 He was under the impression that they did not mind working at the state hospital. The income was decent for West Virginia, and it was a forty-hour a week job with some on-call time, and not a bad position. ${ }^{115}$ Doctors could live at the hospital or in houses owned by the hospital nearby, as well. For many years there was a house on Main Street in Weston owned by the hospital where the superintendent could live. ${ }^{116}$ (A fifties-era annual report mentioned that three new staff cottages had been completed at that time. The Clinical Director and three junior physicians were living in them. They were described as "modern, comfortable, and furnished." ${ }^{\prime 17}$ )

At the time of this 1992 administrative transition, another major change occurred as Weston also brought in West Virginia University Hospital to begin providing psychiatric services for the hospital. Eight or nine psychiatrists eventually came to Weston, working there four days each week. In addition, WVU began to provide clinical psychologists and clinical social workers, who were trained to do therapy. Prior to this, there had been only 
one psychiatrist in the hospital. There was difficulty blending the new WVU people with the state employees. The new clinical psychologists and social workers did not want the unlicensed state psychologists and social workers to do therapy, even though many of them possessed $\mathrm{PhDs}$ and had been doing therapy for years. There was also tension over the differences in salaries. The doctors at Weston were making about $\$ 60,000$ to $\$ 70,000$ and the lowest paid one from WVU earned $\$ 120,000$. The psychologists at Weston were making approximately $\$ 40,000$, and the hospital was bringing in psychologists at $\$ 75,000$ from the university. Dr. Todt remembered it was like trying to get oil and water to mix, but eventually they came to some agreement and worked together. He said it was truly affecting his health when the employees were upset over the new WVU additions to the staff. It was a very stressful time to him. ${ }^{118}$

There was a very large support staff in the 1990s, and a freeze was placed on hiring to begin downsizing for the move to the new hospital. At that point there were about 275 to 300 patients and 650 employees, plus the employees were drawing enough overtime to equal another one hundred employees. Dr. Todt said the units were well staffed, perhaps even overstaffed, but they needed to eliminate the overtime, which was a real strain on the budget. Their real need was for more registered nurses, because the nurses were "the lifeblood of the units, because when the doctors weren't there, the RNs would run them. Past that, there was more than enough staff." ${ }^{119}$ The support staff was reduced as employees retired from the maintenance, dietary, housekeeping, switchboard, and other support departments. Then the hospital began to add more clinical staff and RNs in order to improve treatment. ${ }^{120}$

Working in the hospital was very taxing for all the employees. Dr. Todt remembered being terribly stressed when trying to resolve staff conflicts when they began bringing in West Virginia University personnel to help with treatment. ${ }^{121}$ He pointed out that they did an informal study in the 1990s and determined that they had more staff than patients on psychotropic medications at Weston. Another employee agreed that this was the case at the time they moved to Sharpe Hospital. Dr. Todt attributed this need for anti-anxiety and anti-depressant medications to simply, "It was a hard place to work.".122

Dr. Todt felt that when he worked at the hospital, ninety percent of the employees were hardworking, dedicated, caring people. However, he acknowledged that there were a few who should not have been there. He said it was difficult to fire an employee unless 
they were abusing patients, physically or sexually, but if that was the case they could pretty easily remove them. ${ }^{123}$ He said:

Some of the staff were bad-they were not good. I mean some of them really got a kick out of kind of abusing patients. I mean, they could do it. They could do it very easily, and not get caught at it. They could withhold their food and say, "Well, you were yelling and screaming at me and cussing at me so you don't get to go to the lunchroom." And not all the staff, but the staff could actually- they were abusive at times. ${ }^{124}$

Various restraints were still used in state hospitals if necessary. Mrs. Lowther, the aide, remembered that patients would come right out of a straitjacket. Sometimes a patient would be tied down on a bed. In the nineties, the policy was that first they would try to talk to them. If that didn't work, they would put them in bed with a netting stretched over them to restrain them, which was more humane than a straitjacket. If they yelled and screamed, then they would be sedated. If chemical restraints were used, they had to be justified. The patient advocates insisted — first talk to them, then restrain, then medicate. ${ }^{125}$

Several types of medication were being used throughout this period. Thorazine and Lithium had been introduced in the 1950s, but many others were developed over the decades. Ms. Mason, the RN, recalled that Haldol, Ativan, Stelazine, and Valium were commonly used. ${ }^{126}$ Clozaril was a newer one. Dr. Todt discussed how patients were overmedicated when he arrived. When he had worked as an administrator at Hopemont Hospital (Preston County) with the elderly mentally ill, before coming to Weston, he instructed the staff there to take everyone off their psychotropic medications to find out who really needed them. At first the staff thought he was crazy, but it turned out that half of the patients did not need any. ${ }^{127}$ Dr. Todt related:

Sometimes medications can make patients worse. Sometimes they are acting out because of the medication. Valium can make some people hyper, manic-y, or violent. And some medications can make them dumb and stupid - that's when they're over-medicated. I think the staff really appreciated the new psychiatrists from WVU and how they adjusted the medications. It made the patients easier to care for. We talked to the patients and tracked the results of less medication and having them adjusted more by more psychiatrists. We found less workman's compensation claims, less overtime from others being absent, less injuries. ${ }^{128}$ 
Theft was a serious problem by the 1990s. The day Dr. Todt arrived to begin work at Weston, he was told that a generator had been stolen, though it had been in a locked building. That same day he overheard some "gas guys" say that much of the renovation work that went on in the Weston area used materials from the hospital. He felt this was a result of poor management of the hospital, unethical principles by some higher-level managers at that time, a demoralized staff, and poor pay. Dr. Todt said:

After talking to officials in Charleston about how the hospital and certain management operated regarding hospital resources, I was astounded, mostly that nothing was done about it. In the new hospital, the stealing went on, but I think we got it down to a very, very low level, based on strict inventory procedures and accountability and people, in high positions, finding new opportunities for their lives (not necessarily by their choice). In 1992, the hospital was out of control in more ways than one. ${ }^{129}$

In the last few years of the Weston Hospital's existence, and at the new Sharpe Hospital, they were forced to admit an increasing number of court-ordered patients. These were usually criminals who had committed some type of offense and would stay there until the judge decided to let them go. Dr. Todt remembered trying to defy a judge once who ordered him to take a patient at Sharpe Hospital when they were already over their 150-patient limit. The judge threatened to throw Dr. Todt in jail for contempt of court, so the patient was accepted. If a person was ruled incompetent to stand trial, the hospital kept him until they had stabilized him on medication for six months. If he was ruled to have committed a criminal act because of insanity, he was kept until he was deemed appropriate for the community. They might have to keep a patient for years. ${ }^{130}$

Dr. Todt found the state system difficult at times. He was quite disapproving of political appointees being chosen to help administer hospitals. He strongly believed that those running hospitals should be competent in the health care field. Also, when they were reducing the employee numbers in anticipation of moving to the new Sharpe Hospital, there was an illogical system put in place by the state in which all the service employees ended up being moved into slots where others had retired, but in different departments. Someone who worked in maintenance might be put in dietary, and someone in dietary might be transferred into maintenance. It was all done by seniority and angered the staff. In addition, Dr. Todt was really frustrated right before he left Sharpe at his inability to get 
his secretary a small raise. He said secretaries never got raises and did not earn much, but he was not able to acquire one for her. ${ }^{131}$ Despite these problems, Dr. Todt attested to the improvements at the hospital:

I can tell you by the time they moved into the new hospital within a few years, it was a good place. It was much better. Even David Sudbeck [the court appointed monitor] said-I mean at one point I felt confident enough that I gave the court monitor a key to the units, because he would always have to come to my office and get permission to go on a unit. I finally just gave him a key to the units and said, "Wherever you want to go..." And he did. He would just go look around. And he, by that point, probably by '96, said there was some really good patient care going on. He could see it in the treatment plans. But we had psychiatrists here. We had WVU. We had trained staff. I think it got better. I think it really got better. I would send somebody to Sharpe Hospital now. But I would not have sent them there in 1992. Not because the staff didn't care, they just didn't know what to do. ${ }^{132}$

Dr. Todt truly enjoyed helping bring about better care for the patients. He said he knew the higher standards that the patient advocates were demanding and the standards they needed to meet for the Joint Commission's requirements were things that were going to improve the lives of the patients. The adjustment of and reduction of medications made many of the patients easier to handle. There was a decline in the number of workers' compensation claims as they improved patient clinical care. ${ }^{133}$

The inadequate resources provided for community mental health centers were a concern to many of the employees. Dr. Todt discussed how important it was to reach all those who were discharged from the state hospitals. The federal government cut back on funding to community care through the Reagan-Bush era and the Clinton era. He emphasized that it is difficult to obtain money for the mentally ill; they need advocates to speak for them. He noted that the reason that mental institutions like Weston grew so large was because there was no place to send people — there were no community resources to handle them. Part of the problem with getting people out of the hospital was setting them up in the community. Did they have housing? Financial assistance? Often that was not available. ${ }^{134}$ The attempt to provide mental health care largely on an outpatient basis through community mental health centers would present a challenge carried into the twenty-first century. 
1 “Average Daily Population," $19^{\text {th }}$ Annual Report of the Department of Mental Health, 1976-1977, 13.

${ }^{2}$ Sixteenth Report of the West Virginia Board of Control 1948-1951. Compiled by Robert G.

Hanlen in conjunction with the superintendents of the institutions and under supervision of the Board of Control, 1951, 15-16.

3 “The Westoneer Salutes our Laundry," The Westoneer [patient/staff newsletter], May 1953, 12.

4 "The Westoneer Salutes Dietary Dept.," The Westoneer [patient/staff newsletter], September 1953, 7.

5 “The Westoneer Salutes the Hospital Farm," The Westoneer [patient/staff newsletter], December 1953,7 .

${ }^{6}$ Albert Deutsch, The Shame of the States (New York: Harcourt, Brace and Company, 1948), 27.

${ }^{7}$ Deutsch, Shame of the States, 21.

${ }^{8}$ Ruth Lowther interview, 1,4, 14.

${ }^{9}$ Michael Todt interview, 4-5.

${ }^{10}$ Mildred Haller interview, 2-3, 8.

${ }^{11}$ Board of Control Report 1948-1951, 19, 26.

${ }^{12}$ Mildred Haller interview, 18.

${ }^{13}$ Mildred Haller interview, 11.

${ }^{14}$ Ibid., 13.

${ }^{15}$ Jean White interview, 4.

${ }^{16}$ Board of Control Report 1948-1951, 28.

${ }^{17}$ Jean White interview, 5.

${ }^{18}$ Ibid., 5-7.

${ }^{19}$ Ruth Lowther interview, 15-16.

${ }^{20}$ Michael Todt interview, 26.

${ }^{21}$ Lisa Berger and Alexander Vuckovic, Under Observation: Life Inside the McLean Psychiatric Hospital (New York: Penguin Books, 1995), 11-12.

${ }^{22}$ Shirley Mason interview, 19.

${ }^{23}$ Ruth Lowther interview, 16.

${ }^{24}$ Mildred Haller interview, 12-13.

${ }^{25}$ Jean White interview, 1-2.

${ }^{26}$ Mildred Haller interview, 14

${ }^{27}$ Board of Control Report 1948-1951, 25, 28, 31.

${ }^{28}$ Ruth Lowther interview, 13-14, 21.

${ }^{29}$ The Westoneer, November 1955, 10.

${ }^{30}$ Gerrard, Impact of a Federal Grant, 99.

${ }^{31}$ Mildred Haller interview, 7.

${ }^{32}$ Board of Control Report 1948-1951, 36.

${ }^{33}$ West Virginia Department of Mental Health, 19 th Annual Report, 1976-77, 16.

${ }^{34}$ Mildred Haller interview, 5.

${ }^{35}$ Board of Control Report 1948-1951, 10.

${ }^{36}$ The Westoneer, September 1955, 7.

${ }^{37}$ Louise Burr Gerrard, Impact of a federal grant-in-aid program on an economically depressed, rural state: a case study of mental health programs in West Virginia, (Ann Arbor: University Microfilms International, 1969), 127.

${ }^{38}$ Gerrard, Impact of a Federal Grant, 127-28.

${ }^{39}$ Gerrard, Impact of a Federal Grant, 94-97.

${ }^{40}$ Ibid., 137.

${ }^{41}$ Mildred Haller interview, 5-6.

42 Jean White interview, 9.

${ }^{43}$ Gerrard, Impact of a Federal Grant, 140-147. 
${ }^{44}$ Ibid., 147-49, 153-56.

${ }^{45}$ West Virginia Department of Mental Health Annual Report, 1966-1967. Charleston, West Virginia. M. Mitchell-Bateman, M. D. Director, 3.

${ }^{46}$ Ibid., 3-9.

${ }^{47}$ Gerrard, Impact of a Federal Grant, 165-66.

${ }^{48}$ Karl Staubly interview, 14.

${ }^{49}$ Karl Staubly interview, 6, 8.

${ }^{50}$ Karl Staubly interview, 12, 16.

${ }^{51}$ Ibid., 12.

${ }^{52}$ Ibid., 11.

${ }^{53}$ Karl Staubly interview, 4-5.

${ }^{54}$ Ibid., 4-5.

${ }^{55}$ Security guard interview, 10.

${ }^{56} \mathrm{Karl}$ Staubly interview, 5 .

${ }^{57}$ Karl Staubly interview, 21.

${ }^{58}$ Ibid., 24.

${ }^{59}$ Shirley Mason interview, 1,4 .

${ }^{60}$ Security guard interview, 5 .

${ }^{61}$ Richard L Lael, Barbara Brazos, and Margot Ford McMillen, Evolution of a Missouri Asylum:

Fulton State Hospital, 1851-2006 (Columbia, Missouri: University of Missouri Press, 2007), 31.

${ }^{62}$ Richard F. Salisbury, Structures of Custodial Care: An Anthropological Study of a State Mental Hospital (Berkeley: University of California Press, 1962), vii.

${ }^{63}$ Ibid., 53-54.

${ }^{64}$ Michael Todt interview, 21.

${ }^{65}$ Ruth Lowther interview, 2.

${ }^{66}$ Karl Staubly interview, 4.

${ }^{67}$ Thom Haller interview, 13.

${ }^{68}$ Michael Todt interview, 13.

${ }^{69}$ Shirley Mason interview, 5 .

${ }^{70}$ Charles Knapp, "Doctor Quits Weston, Rips Staff Colleagues," Charleston Gazette, 30 August 1980,7B.

${ }^{71}$ Ibid.

${ }^{72}$ Ibid.

${ }^{73}$ Anonymous housekeeper interview, 7, 10, 25.

${ }^{74}$ Ruth Lowther interview, 11.

${ }^{75}$ Security guard interview, 5,19.

${ }^{76}$ Thom Haller interview, 10.

${ }^{77}$ Anonymous housekeeper interview, 16-17.

${ }^{78}$ Ibid., 11.

${ }^{79}$ Shirley Mason interview, 29.

${ }^{80}$ Ibid., 27.

${ }^{81}$ Shirley Mason interview, 27.

${ }^{82}$ Ibid., 25.

${ }^{83}$ E-mail from Michael Todt to Kim Jacks, March 17, 2008.

${ }^{84}$ Shirley Mason interview, 25, 30.

${ }^{85}$ Michael Todt interview, 3.

${ }^{86}$ Ruth Lowther interview, 22.

${ }^{87}$ Shirley Mason interview, 13.

${ }^{88}$ Thom Haller interview, 17.

${ }^{89}$ Shirley Mason interview, 27; Michael Todt interview, 18.

${ }^{90}$ Ruth Lowther interview, 18; Shirley Mason interview, 10.

${ }^{91}$ Michael Todt interview, 18.

${ }^{92}$ Ruth Lowther interview, 5-6.

${ }^{93}$ Shirley Mason interview, 23. 
${ }^{94}$ Thom Haller interview, 6-7.

${ }^{95}$ Anonymous housekeeper interview, 20-21.

${ }^{96}$ Michael Todt interview, 26-27.

${ }^{97}$ WV Department of Mental Health Report, 1976-77, 16.

${ }^{98}$ P. Kay Nottingham, "Volunteer working to improve Weston State Hospital image," Morgantown Dominion Post, August 20, 1986.

${ }^{99}$ Michael Todt interview, 19.

${ }^{100}$ Lawrence Chapman, History of Weston Hospital, Vol. 1 (Weston, WV: by the author, 1988), 104.

${ }^{101}$ George Dowdall, The Eclipse of the State Mental Hospital: Policy, Stigma, and Organization

(Albany, NY: State University of New York Press, 1996), 44.

${ }^{102}$ Michael Todt interview, 2.

${ }^{103}$ E-mail from Michael Todt to Kim Jacks, March 19, 2008.

104 "Weston Hospital Administrator Ousted," Weston Democrat, Oct. 7, 1992, 1, 7.

${ }^{105}$ Michael Todt interview, 3.

${ }^{106}$ Anonymous housekeeper interview, 5.

107 "Removal of Valdov: An Outrage," Weston Democrat, October 7, 1992, 4A.

${ }^{108}$ Ibid., 4A.

${ }^{109}$ Michael Todt interview, 5-7.

${ }^{110}$ Ibid., 13-14.

${ }^{111}$ Ibid, 8 .

${ }^{112}$ Michael Todt interview, 7-9.

${ }^{113}$ Karl Staubly interview, 6.

${ }^{114}$ Michael Todt interview, 7.

${ }^{115}$ Ibid., 7, 12.

${ }^{116}$ Mildred Haller interview, 19.

${ }^{117}$ Board of Control Report 1948-1951, 27.

${ }^{118}$ Michael Todt interview, 17, 20-21.

${ }^{119}$ Michael Todt interview, 13.

${ }^{120}$ Ibid, 13.

${ }^{121}$ Michael Todt interview, 21.

${ }^{122}$ Ibid., 18.

${ }^{123}$ Michael Todt interview, 18-19.

${ }^{124}$ Ibid., 18.

${ }^{125}$ Michael Todt interview, 29.

${ }^{126}$ Shirley Mason interview, 10.

${ }^{127}$ Michael Todt interview, 28-29.

${ }^{128}$ Ibid., 29.

${ }^{129}$ E-mail from Michael Todt to Kim Jacks, March 19, 2008.

${ }^{130}$ Michael Todt interview, 10.

${ }^{131}$ Michael Todt interview 4, 22, 24.

${ }^{132}$ Ibid., 19.

${ }^{133}$ Ibid., 14, 17.

${ }^{134}$ Ibid., 8-9. 


\section{Conclusion De-institutionalization}

\section{Into the community, the streets, the jails....}

The peak for patient population at Weston State Hospital was in the mid-1950s to the early 1960 s at over 2,300 patients. In the next few decades, a decline in hospital population occurred due to new medications and to a reevaluation of patients' rights and commitment policies. ${ }^{1}$ The Weston hospital's average daily population remained above 2,000 until 1968. It declined to under 1000 by 1980. After the Hartley and Medley cases in West Virginia in the early 1980s, advocates for the mentally ill insisted that certain rules and regulations be followed to provide high quality care for patients in state hospitals. And in order for Weston to become accredited under the Joint Commission and Medicare, strict guidelines had to be followed regarding patient care, patient rights, and the physical facility. These new standards, plus the prohibitive cost of renovating the old Weston Hospital, led to the construction of the new William R. Sharpe, Jr. Hospital, which had a capacity of only 150 patients, on the rear acreage of the Weston hospital property.

The deinstitutionalization of mental patients, which happened nationwide, was particularly dramatic in the state of West Virginia. West Virginia had a total of 5,410 mental patients in 1964 and only 224 in 1994, a decrease of 96\%, one of the highest reductions in the nation. Theoretically, patients released from hospitals were to be under the care and supervision of local community health centers. As Dr. Todt, the administrator, explained, once a patient was released from the hospital, they were to go to a previously arranged appointment with the local mental health agency to receive follow-up care, at least with medication. In the early 1990s, funding for mental health centers was being decreased, so they had few resources. "If the patient didn't make the appointment, more often than not, they got lost in the cracks - they just dropped through the cracks, nothing would happen. 
There was no other treatment past that." 2 Dr. Todt commented that funding for community mental health declined through the 1980s and 1990s. ${ }^{3}$ Dr. Todt noted that even when the hospital population was over 2000, it was not that they would not have liked to get people back into the community, but there were no resources for them- the communities could not handle them. ${ }^{4}$

Unfortunately, many of the former mental hospital patients have now become incarcerated in the state's jails and prisons. In 2004, 37,000 people were treated for mental illness in West Virginia's regional jails. ${ }^{5}$ Public Broadcasting's Frontline aired a program in May 2005 exploring the problems facing state penal institutions nationwide as they now deal with the mentally ill. Approximately 50,000 people are now treated in psychiatric hospitals in the United States, and over 500,000 of the mentally ill are incarcerated in state jails and prisons, which is about a fourth of the nation's two million inmates. According to the National Alliance for the Mentally Ill, sixteen percent of the prison population and twenty-five percent of the jail population can be classified as severely mentally ill, suffering from schizophrenia, major depression, and bipolar disorder. The numbers are much higher when other mental illnesses, such as depression, anti-social personality disorder, and borderline personality disorder are included. If inmates suffering from substance abuse are included, the number is well over fifty percent. ${ }^{6}$ In the Frontline episode, entitled "The New Asylums," they visited Ohio prisons and found many of the mentally ill ended up in maximum-security prisons because they were unable to follow the rules in minimum-security facilities. They may have committed only minor crimes, or violated parole, but because of acting out or not cooperating with guards, they often ended up in isolation in maximumsecurity prisons. The strict discipline in prisons and being held in isolation leads to further degeneration of a person's mental health. Ohio's prison system has been able to provide some treatment to the mentally ill, though that is not the case in all states. These prisoner/ patients were stabilized when on proper medications, but when released from prison it was difficult for many to continue taking them. Upon release they were given a two-week supply of medication, but often a month elapsed before they were able to schedule an appointment with a doctor to continue them, and once regular administration of medications was interrupted, deterioration of their mental health would occur. The mentally ill sometimes discontinue their medications because they believe they make them feel worse. Others may think they feel well, and so decide that they do not need the medications any longer. 
Another problem resulting from the deinstitutionalization of the mentally ill is that some former patients might be a danger to others. In another broadcast of Public Broadcasting's Frontline, entitled "A Place for Madness," this issue was addressed. The program focused on Northampton, Connecticut, site of a major mental institution that was gradually emptied in the 1980s. Many of the former patients blended into the community without much difficulty. The problem in Northampton, however, was with a few patients who could possibly be a danger to themselves or others. A middle-aged couple was interviewed who had a thirty-year-old son with bipolar disorder. He had assaulted them on one occasion, but had been intelligent and smooth-talking enough to convince a judge that he did not deserve commitment to a mental hospital. He had disappeared, and his family feared for his safety and theirs. He could only be re-committed to an institution if he committed a crime and was arrested. Another scene in the program involved a former patient who lived at an inexpensive motel along with many other formerly institutionalized people, supervised by a motherly motel owner. He had not taken his medications for several days and his behavior was becoming inappropriate, so the police arrived and convinced him to go to a hospital temporarily. They secured a 12-inch bladed knife the man had next to him as he sat in his doorway. There is a moral and legal dilemma in finding a balance between the rights of mentally ill people and protecting them and society. People can be involuntarily committed only if they are a "danger to themselves or others," and this has been rather narrowly interpreted, leaving the possibility of harm coming to some of the mentally ill or to those they encounter in their communities. ${ }^{7}$

Many of the patients released from mental hospitals in the last few decades have become part of the growing homeless population in the United States. Numerous studies have found that twenty-two to twenty-four percent of homeless people report having formerly been patients in psychiatric hospitals. In studies that narrow the focus to only the homeless that are not in shelters, but living on the streets, the percentage of former mental patients jumps to $75 \%$ in New York City and $77 \%$ in Los Angeles. ${ }^{8}$ Studies show that these people are more likely to be victims of violence, to have accidents and injuries, and to search for food from garbage. ${ }^{9}$ Many of the mentally ill who are charged with crimes have committed their offenses as a result of delusions from their illnesses. For example, one man smashed a plate glass window of a store because he thought he saw a dinosaur jumping out at him, another man harassed two men he believed to be CIA agents that had kidnapped someone he knew, and one woman refused to pay her restaurant bill because 
she thought she was Jesus Christ. ${ }^{10}$ The world is fraught with dangers, both real and imagined, when one is mentally disturbed and on the streets. Community based care for these people may be preferable to the huge institutions, but proper funding has not been provided to handle all who need care and supervision.

So, following this trend of deinstitutionalization, Weston State Hospital was finally closed in 1994. The last patients were transferred to a new facility, the Sharpe Hospital, built on the back part of the former hospital farm. The Sharpe Hospital serves 150 patients and is quite attractive; it even has a beautiful swimming pool. In the late 1980s, there had still been well over 600 employees working at Weston State Hospital. ${ }^{11}$ Some retired, many maintained their positions at Sharpe Hospital, and approximately one hundred had to be let go. ${ }^{12}$

Mental health care funding has suffered cutbacks in recent years. In the late 1990s, West Virginia mental health agencies were accused of mismanagement of federal funds for community health care and were told to repay ten million dollars. Medicaid, which was supposed to be used only for medical expenses such as doctor's visits and prescription drugs, had been "maximized" by mental health providers with the encouragement of state officials. Mental health providers had been using Medicaid funds for such things as running group homes where the mentally ill lived with supervision, and operating day treatment centers where clients learned life skills such as how to shop, cook, and make a budget. Rather than have to repay the debt, the state agreed to drastically cut back on Medicaid funds used and turn the mental health system over to a managed care company, so the state lost about forty percent of its funding. Many group homes were closed and fewer caseworkers have been available to assist clients. General hospitals are increasingly treating the mentally ill, some of whom come to emergency rooms several times a week.

In 2004 the state's psychiatric hospitals were full, and West Virginia had to spend \$3.5 million dollars to have one thousand patients treated for mental problems at private facilities. ${ }^{13}$ West Virginia had the eighth highest suicide rate in the nation in $2006,{ }^{14}$ and more than a fourth of the prisoners in the state's regional jails were treated for mental health problems in 2004. ${ }^{15}$ Steve Canterbury, director of the state's regional jail system, said, "De-institutionalization is a myth. We took them out of mental institutions, put them out on the street, and again and again, they've ended up in our jails." ${ }^{\prime 16}$ The cost of a patient spending a year in a jail at $\$ 23,000$ is much less than a year in a mental hospital would be, but a year in a community-based program like the Assertive Community Treatment (ACT) 
program costs only $\$ 8500$ a year. The ACT program provides a team of caregivers that provide assistance to mentally ill persons while they live in their homes. In West Virginia, only a few people in Charleston and Clarksburg have access to this program. ${ }^{17}$

The now empty Weston State Hospital building was accepted as a National Historic Landmark by the National Park Service in 1990. In 1998 it was listed as one of "America's Historic Landmarks at Risk." The deterioration of the building has made it difficult to find an alternative use for it. A volunteer group of Lewis County citizens, the Weston Hospital Revitalization Committee, began searching for a reuse of the building. In 1999 a $\$ 750,000$ "Save America's Treasures" grant was secured for rehabilitation work. ${ }^{18}$ This was matched by state money for a total of one and a half million dollars, some of which was used for repairs of the roof. In 2000, the volunteer Revitalization Committee raised tens of thousands of dollars for renovations. Over the years, several developers floated ideas for the building and grounds. One had hoped to turn the complex into a 300-room hotel and convention center, with a golf course, shopping, condominiums, and office space, but was unable to raise the $\$ 88$ million needed for renovations. Another planned a 500-room hotel, a PGA golf course, horseback, biking and walking trails, a 3000-seat theater, and the development of several businesses in the downtown area. This also did not materialize. ${ }^{19}$ There was controversy over proposals to permit gambling at the former hospital as part of its development as a resort, and the community voted to allow gambling there, though the resort plans did not materialize. ${ }^{20}$ In 1999 the old hospital was vandalized by a group of twenty off-duty policemen who engaged in a paintball battle there. All four stories of the main building were damaged by thousands of globs of paint. The policemen had convinced a security guard that they had permission to conduct training exercises there. Estimates were that it would cost $\$ 10,000$ to $\$ 30,000$ to clean up the mess, which covered walls, floors, ceilings, window frames, light fixtures, and hand-carved walnut woodwork. Most of the participants were contrite and willing to help repair the damage. ${ }^{21}$

In 2007 the Department of Health and Human Resources of West Virginia decided to auction the Weston Hospital and 307 acres. The auction was held in front of the Lewis County Court House in Weston on August 29, 2007, in front of a large crowd of interested citizens. The auctioneer began with a suggested bid of three million dollars. No one spoke up. He then tried two million dollars. Again no one bid. He dropped the price to $\$ 500,000$ and the interested parties began to bid. Only two people continued after the 
price reached one million. One was a woman from Pittsburgh who was hoping to renovate the hospital and open some type of health facility geared toward the elderly and veterans. The other was a man who owns an asbestos removal business in Morgantown. The asbestos removal contractor, Joe Jordan, won the auction by bidding one and a half million dollars. After the bidding, Mr. Jordan assured reporters that he was not going to tear down the main building. He would be looking for interested investors and deciding what to do with the property.

By 2008, the Jordans had completed enough repairs to the main building to open parts of the four floors for tours, and last October they had "a haunted house walk" down one wing. Hundreds of visitors have come for tours. The Jordans' most recent plan, as of March 2008, was to develop a mud bog on part of the property, where trucks would try to speed through a pit without getting stuck. The local citizens have some reservations about the noise level of such activity. Controversy has developed over the Jordans' decision to rename the property the Trans-Allegheny Lunatic Asylum. The West Virginia Mental Health Consumers Association issued a press release protesting the new name because it was "discriminatory and promotes stigma and misunderstanding of mental illness." The Jordans responded that they plan an educational experience for visitors that will include both the positive and the negative aspects of the history of the hospital. ${ }^{22}$ The old name attracts more attention than "Weston State Hospital," but critics argue that the word "lunatic" is insulting and that the new owners "have gone too far, disparaging the suffering of former patients and reopening wounds with planned events like 'Psyco Path' dirt bike races on the grounds." 23 The Jordans continue to look for investors and have listed the property on Ebay in attempts to attract investment.

Three cemeteries, which were not part of the hospital sale, remain on the hill behind Weston State Hospital, used from 1858 to 1972. If there was no family to claim a deseased patient, or if the family could not afford to retrieve the body, then the patient was buried at the hospital. Some of the patients buried there are ones who died from contagious diseases. Also, some bodies of those who died in the hospital were sent to West Virginia University as cadavers for research. Several thousand were buried in the hospital cemeteries, but very few had grave markers. At one time there were numbers on plaques at each gravesite corresponding with a list kept in the hospital, but these plaques were removed at some point, perhaps to make mowing the cemeteries easier. The cemeteries became overgrown with brush after the 1970s, but in 1998, a Lewis County woman whose father had 
been buried at the hospital brought attention to this, and the cemeteries were cleared and new fences built. Marble monuments were placed at the entrances of each of the cemeteries. $^{24}$

So now, in 2008, one hundred and fifty years after the first laborers began construction of this historic structure, this monument to the story of America's attempt to institutionalize the mentally ill stands quietly, still awaiting its fate. How will the hospital be remembered? Former methods of treating the mentally ill are now viewed with amazement - a continuous bath? A lobotomy? However, most of these treatments were conducted as sincere attempts to improve the lives of the patients. The causes of mental illness were not understood, nor are they truly now. One day our present medications may be disparaged as much as former wet pack treatments and cribs are now. We now treat even preschoolers with psychotropic medications, without knowing possible side effects. Perhaps one day our attempts at the "best of modern medicine" will be viewed with amazement.

Was Weston State Hospital a failure or was it a success? It was a failure to those who were harmed by lobotomies or who received no treatment at all. It was a success to those who received helpful treatment and were able to return to their homes and work. It was a failure to those who were abused or who found a way to take their own lives. It was a success to the chronically ill in providing a home for those who had no one else able or willing to care for them. There may have been many people held in Weston State Hospital who were no more mentally ill than most of us. There were certainly people there who had recovered from their illnesses but had nowhere to go and so made the hospital their home. And of course there were those who were sadly ill and in need of constant care and supervision. Though some people were mistreated, there were also innumerable acts of kindness performed as aides and doctors and nurses and others attempted to do what they could for the patients, using the insufficient resources available to them. One former physician at Weston State Hospital, Charles Chong, complained to the Charleston Gazette as he resigned in 1980 that he felt many of his fellow physicians at Weston did not give adequate care to the patients, but he noted "the one saving grace" of the institution was "the employees on the wards providing direct patient care, especially the nurses and psychiatric aides. Not only do they perform every task... but they do provide the 'care' that society forsakes when it commits a person to an institution." 25 If criticism is due for the care, or lack of it, provided in Weston and other institutions, blame should be placed on 
the governments and the citizens behind them who under funded care for the mentally ill over the decades.

Americans continue to struggle with satisfactory ways to care for the mentally disturbed. Early advocates for the mentally ill such as Dorothea Dix and Thomas Kirkbride often reminded their audiences that one never knew who would succumb to mental illness, and urged them to reflect on how they would want to be treated if struck by this malady. We now attempt to deal with the mentally ill through community care, but again have not provided enough services to reach all those who need assistance. The lesson for us today could be to shift more of our nation's tremendous wealth to the care of those who are the most vulnerable and the most needy of any people in our society. Holding the mentally ill in jails or prisons is not tolerable. Letting them drift among the homeless is not tolerable. As hopefully the old Weston State Hospital building will be saved and maintained, let us hope that Americans in the twenty-first century will decide to invest in our mentally ill population and save them, too, from being ignored and abandoned.

Notes

${ }^{1}$ Joy Gilchrist-Stalnaker, A Short History of Weston Hospital (Weston, WV: Hacker's Creek Pioneer Descendants, 2001), 8 .

${ }^{2}$ Michael Todt, interview with Kim Jacks, November 1, 2007, 8.

${ }^{3}$ Michael Todt interview, 9.

${ }^{4}$ Ibid.

${ }^{5}$ Finn, "Is State Failing the Mentally Ill?" Charleston Gazette, January 2, 2005, 5B.

${ }^{6}$ Frontline: The New Asylums, Boston: Public Broadcasting Service WGBH Educational Foundation:

1995-2005 [Internet]; available from http://www.pbs.org/wgbh/pages/frontline/shows/asylums/etc/ faqs.html, accessed 15 April 2006.

${ }^{7}$ Frontline: A Place for Madness, writ. and prod. by DeWitt Sage, WGBH Educational Foundation PBS Video, 1994, video recording.

${ }^{8}$ E. Fuller Torrey, Out of the Shadows: Confronting America's Mental Illness Crisis (New York: John Wiley and Sons, 1997, 22-23.

9. Ibid., 19.

${ }^{10}$ Ibid., 28.

${ }^{11}$ Chapman, History of Weston Hospital, Vol. 2, (Weston, WV: by the author, 1988), 2.

${ }^{12}$ Michael Todt interview, 22.

${ }^{13}$ Finn, "Is State Failing the Mentally Ill?" 5B. 
${ }^{14}$ National Alliance on Mental Illness, "Grading the States 2006: West Virginia Narrative," [Internet]; available from http://www.nami.org/gtstemplate.cfm?section=grading the states\&template=/ ContentManagement/ContentDisplay.cfm\&ContentID=30906, accessed 23 March 2008.

${ }^{15}$ Finn, "Is State Failing the Mentally Ill?" 5B.

${ }^{16} \mathrm{Ibid}$.

${ }^{17}$ Ibid.

${ }^{18}$ Gilchrist-Stalnaker, Short History of Weston Hospital, 10.

${ }^{19}$ Weston Hospital Revitalization Committee, Weston, WV: c2005, [Internet], available from http:// www.westonlandmark.com/index.htm, accessed 10 April 2006.

${ }^{20}$ Weston Hospital Revitalization Committee website, accessed 6 March 2006.

${ }^{21}$ Cindi Lash, "A town sees red over police vandalism," Pittsburgh Post Gazette, 20 June 1999 [Internet]; available from http://www.postgazette.com/regionstate/19990620paint4.asp, accessed 9 April 2006.

22 “Old Hospital Name Stirs Controversy," Weston Democrat, March 19, 2008, 1, 6A.

${ }^{23}$ Vicki Smith, "Asylum's renaming insults advocates,”Associated Press, Yahoo News. [Internet]; available from http://news.yahoo.com/s/ap/20080321/ap_on_re us/lunatic_asylum, accessed $20 \mathrm{March}$ 2008.

${ }^{24}$ Weston Hospital Revitalization Committee, [Internet]; available from http:// www.westonlandmark.com/index.htm, accessed 6 March 2006.

${ }^{25}$ Charles Knapp, "Doctor Quits Weston, Rips Staff Colleagues," Charleston Gazette, August 30, 1980,7B. 


\section{Appendix Voices from Weston}

The former employees of Weston State Hospital who consented to interview for this project provided a variety of interesting stories. Some of their recollections fit into the chronological history traced in Chapter 3, but many more of their reminiscences are related in this appendix. Their memories provide a colorful picture of life at the hospital, the good and the bad, the pleasant and the unpleasant. These people worked in various periods from the 1950s to the 1994 closing of the Weston Hospital, and some continued employment at the new William R. Sharpe, Jr. Hospital, which replaced Weston. The stories from these interviews provide us with images of life at the hospital, and perhaps some appreciation of their efforts on behalf of our society - caring for those people that the rest of us could not, or would not, care for ourselves.

\section{The interviewees}

Let me briefly introduce the people I spoke with, and then I will attempt to construct a description of life at the hospital in the second half of the twentieth century as they perceived it. I first spoke with Dr. Michael Todt, a Detroit native, who was actually the last of these interviewees to arrive at the hospital. He was hired as Director of Clinical Support Services in 1992 and was given the responsibility of helping gain accreditation for the hospital under the Joint Commission on the Accreditation of Hospitals. This certification was necessary for the opening of the new facility planned to replace the Weston hospital, and to ensure eligibility for receiving Medicare and private insurance. Dr. Todt had a background in business consulting. He also held a Ph.D. in psychology and had been an administrator at Hopemont, a facility for the elderly mentally ill in Preston County. Dr. Todt was hired at Weston when a murder and suicide precipitated a change in administration. He then helped supervise the transition to the new hospital and became the administrator of the Sharpe Hospital in $1994{ }^{1}$ 
Next I spoke with Ruth Lowther, who was employed as a health service worker from 1968 to 1999. She was able to provide an overview of the changes that occurred at the hospital from the days when there were huge patient populations receiving mostly custodial care, through the deinstitutionalization period and the closing of Weston, and the first several years at the Sharpe facility. Mrs. Lowther described the very crowded conditions that existed when she began work in the 1960s and the multitude of tasks that the health service workers, or aides, were expected to perform. They were responsible for everything from nursing duties like administering medications and injections, to cleaning floors (every shift), bathing patients (which took all morning), checking and counting the silverware after a meal, and continually supervising a crowded ward. At one point she and one other aide were responsible for sixty-five people in a "chair-bed ward," a geriatric ward for those confined to chairs or unable to get out of bed. ${ }^{2}$ Mrs. Lowther, a Weston area resident, continued working at the Sharpe Hospital after the closing of Weston in 1994, and then retired in 1999. She can still be seen at the Sharpe Hospital. She laughed, "And I must have enjoyed it because I still volunteer up at Sharpe. I enjoyed it." ${ }^{3}$ Mrs. Lowther seemed to feel that her career at the hospital was satisfying and worthwhile.

Shirley Mason served as a registered nurse at Weston from 1979 to 1990. Registered nurses were always in demand at Weston; there were never enough. Ms. Mason worked on the night shift most of her years at the hospital, usually as the only RN. She was responsible for the entire population, which included a complex of several buildings in addition to the immense main building. Ms. Mason spent much of each night moving among the wards, keeping in contact with all staff through a pager. Her stories reflected her development of management skills that allowed her to deal with the large population of challenging patients without much difficulty. She almost seemed to have a sixth sense about the patients at times. Once, when a patient was being admitted, after being searched by the state trooper who brought him in, Ms. Mason observed that he was acting suspiciously. She proceeded to search him herself and found a knife hidden in his shoe. Ms. Mason, like all these employees, described the importance of knowing how to "talk a patient down" when one became agitated. She related that she weighed only 99 pounds when she quit working; she did a lot of walking on her shift. Ms. Mason was a Weston native, but had gone away to nursing school and then worked in a general hospital in Mansfield, Ohio, in surgery, for several years, before returning to work at the hospital in Weston. ${ }^{4}$ 
A security guard for most of his career at Weston, Bill (who asked that I just use his first name) worked from 1976 to 1995, with a three-year break in the middle of that period. He also worked as a switchboard operator and as a receiving clerk in the later years of his employment. Bill and his wife had come to Weston in the 1970s to gain employment at the hospital. He recounted many stories of dealing with difficult patients, often resulting in injuries to himself, particularly in dealing with the patients as they were admitted for drug and alcohol problems. He noted that he rarely had problems with those who were the "truly mentally ill," and grew fond of many of them, but related memories of difficult encounters with some other patients. He said he was always afraid of hurting someone, and believed that he never did — there was an art to handling problematic patients. Bill served as a representative with the employees' union and so worked for workers' concerns, as well. ${ }^{5}$ He left the hospital in the early 1980s after he felt he had "had enough," following a fight that had taken place between several health service workers and some of the forensic, or criminal, patients. (Bill was not involved in the incident but had strong opinions about it.) He returned to the hospital a few years later. He continued working as a security guard for several months and then transferred to the switchboard. He had suffered many injuries on the job over the years and was no longer able to run well after knee surgeries, so he felt he was not physically able to continue as a security guard any longer. ${ }^{6}$

Karl Staubly worked at the hospital from 1971 to 1993 as a case manager and counselor in the Alcohol and Drug Abuse Treatment Unit. He held a degree in psychology from Vanderbilt and had worked in psychiatric wards in the U.S. Army, and then briefly with the Peace Corp. He also had worked in Washington, D.C. with juvenile delinquents, and at the federal prison in Alderson, West Virginia. He was asked to come to Weston and work in the Alcohol Treatment Unit (ATU) and agreed, thinking it might be better than working in the prison system, though he had never heard of Weston. He served as a case manager, conducted classes in substance abuse education, acted as a therapist in individual counseling, was a unit director at times, and was a patient advocate for the unit. As a case manager, Mr. Staubly supervised a patient's program at the hospital and worked with community mental health personnel to help arrange support and living arrangements after discharge. As a patient advocate, he sought to rectify problems when patients had complaints about their treatment or needed other assistance. ${ }^{7}$ The ATU staff assisted patients through a detoxification program to help them become free of their addictions. 
This unit was the one part of the hospital where, with the exception of medications used in detox, the goal was to get the patients away from drugs; while the rest of the population of the hospital was largely being treated with drug therapy throughout the 1970 s and $1980 \mathrm{~s}^{8}$

The hospital employed a number of college students each summer. Thom Haller was one of those students, and worked at the hospital each summer from 1976 through 1979. He worked with the Behavioral Therapy Unit the first summer, which was a unit developed to prepare patients for life outside the institution. Patients were given instruction in hygiene and basic skills such as "tell time class." In that summer and then through the following three, when Mr. Haller was assigned to the Recreation Department, he was primarily involved in providing the patients with interactive activities. He described his first summer succinctly, "We played canasta." He and the other recreation department employees brought activities such as card playing and checkers to the wards. They also took patients outside for games, arranged dances, and occasionally took patients on trips to state parks. ${ }^{9} \mathrm{Mr}$. Haller was able to remember several patients vividly, describing them and their conversations in detail. He described his time working at the hospital as a period of deinstitutionalization, illustrated by what he was able to do with the patients: The first summer they played canasta, and the second year spades; both of these requiring memory

Student employees in the late 1970s.

Photo courtesy of Thom Haller, seated in first row, second from left.

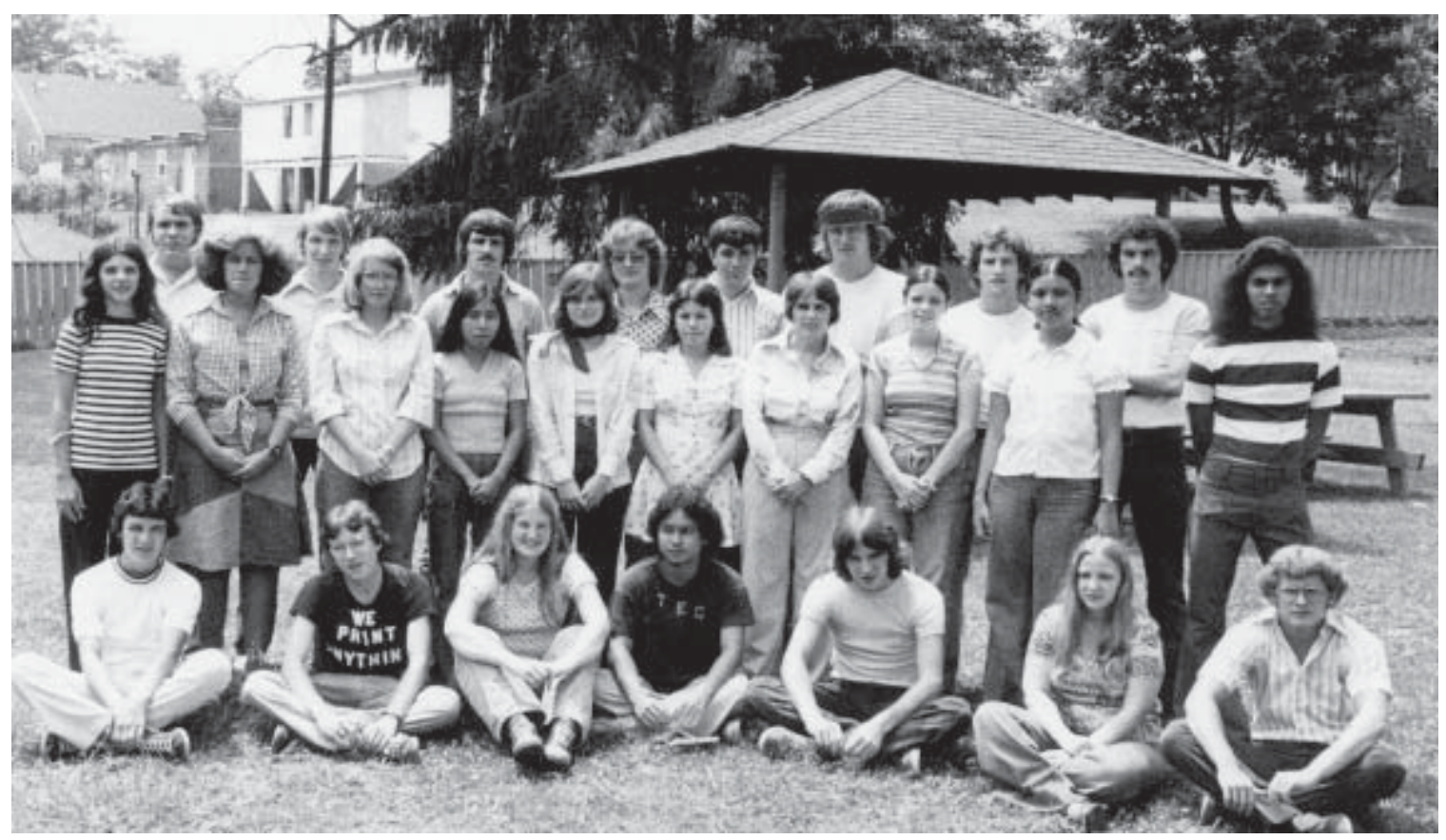


and concentration. The third year they played rummy, and, "Year four it was war, if you were lucky." ${ }^{\prime 0}$ His stories reflected humor blended with true affection for the patients. Mr. Haller now lives in Washington, D.C. and works in business consulting as an "information architect," helping businesses improve communications. He also teaches writing part time at the University of Maryland.

I then spoke with a woman who worked in the housekeeping department for many years; she asked to remain anonymous. She worked at Weston from the 1970s until 1994 and then for several years at the Sharpe Hospital until her retirement. She was able to provide not only an account of the hard work involved in keeping the hospital buildings clean (which, by the way, all the other interviewees attested to by saying that things were kept clean), but she was also able to tell many stories of difficult experiences at the hospital, such as times when murders and suicides had occurred. Her perspective was also different from the other employees, given that she was assigned to wards with the most severely mentally ill patients and remembered details about these people. She described everything from having to use sheets to soak up blood on the floor after fights to having to clean up when patients placed their feces in exhaust fans. ${ }^{11}$ Remarkably this woman continued her work for twenty-seven years. At one point she passed an exam to become a health service worker, but decided to remain in housekeeping. As she said, "I'd rather clean up their messes than to have to fight with them. I wasn't going to fight with them. I couldn't do that." ${ }^{\text {"2 }}$ But she, too, expressed fondness for many of the patients and employees.

An interview with Mildred Haller provided a view of the hospital in the early 1950s. She worked in the business office there from 1951 to 1955, before she had her three sons - one of whom was Thom, the aforementioned student employee in the recreation department. While Mrs. Haller worked at the hospital, she did not need to go on the wards, but interacted with the patients who came into the offices. She remembered one who called himself John D. Rockefeller and was always very seriously discussing how he was going to get them money for this and for that. Though this man actually had a different name, he was listed on a patient employee list as John D. Rockefeller, having received five dollars for his work as a mail carrier. Mrs. Haller recalled the prevalence of shock treatments at the hospital when she worked there—she said, "They gave everybody shock treatments back then." Lobotomies and sterilizations were common as well. They were so common, she said, 'You know, you just rattled off, 'Oh, he's getting a lobotomy.' You 
didn't think anything about it." ${ }^{\prime 3}$ These treatments were not unique to Weston. By 1936, at least twenty-five states had sterilization programs in their state hospitals. ${ }^{14}$ Over five thousand lobotomies were performed in the United States in 1949. ${ }^{15}$

I also interviewed my parents, longtime residents of Weston (the town, not the hospital). My father, Ross White, who passed away in the summer of 2007, told me about his experiences playing high school football games on the lawn of the state hospital during the 1930s. He was also a member of the $201^{\text {st }}$ National Guard unit that assisted in caring for the patients when a fire swept through the hospital in 1935. My mother, Jean White, remembered visiting the hospital as part of a church women's group. She also related stories of people she knew who were patients at the hospital for a time, including an aunt who underwent shock treatments in $1953 .{ }^{16}$ She and Mrs. Haller, as well as other employees, expressed how important the hospital was to the economy of Weston. ${ }^{17}$

I, also, worked in the hospital—briefly—as a summer college employee in 1977. I was placed in a social work office and given responsibility for conducting social work tasks for one county's worth of patients. This was during the period when the units were divided geographically; so all patients from one county were placed in the same unit regardless of diagnoses. They had just moved the Webster County patients from one of the other units to the one I had been assigned to, and the social workers there were already feeling overwhelmed. They told me, "You can take care of the people from Webster County." Having no background in social work or mental health care of any kind, and having never been in the hospital except for a few 4-H club Christmas caroling excursions, I gave it a go. They allowed me to write up social work evaluations of new admissions, do case work, and arrange for discharges of some of the patients in coordination with the community social workers. It frightens me a little to think back on the responsibilities they gave me, but they must have kept an eye on me and really felt stretched thin enough to need my assistance. That summer was an eye opening experience for me, coming from my sheltered background, but I was surprised to find that most of the patients were not frightening, but often childlike.

After conducting these interviews, I was impressed with these last employees of Weston State Hospital. The people I spoke to, from administrators to housekeepers, possessed an attitude of care and understanding for the patients that was quite remarkable. There were numerous incidents mentioned that reflected their kindness and empathy toward the patients. My thanks to them for sharing their memories of the hospital. 


\section{Those first days on the job: "Why am I here?"}

Several of the employees I spoke with remembered their first impressions of the hospital and their challenging first days of work there. Mr. Haller, the college student, recalled arriving at the hospital for the first time with two other students, entering through the large wooden front doors into the entry corridor, which was huge and echo-y. He said with a laugh, "I think we all had that sense of, 'Oh my god, what have we done?""18 $\mathrm{He}$ described the hospital as more curious, though, than frightening. Mr. Haller was not afraid of the patients, but remembered being disturbed by the combination antiseptic and urine smell that pervaded many of the wards. Everyone got used to this, however. (Mr. Haller said, with a laugh, that years later if he walked into a parking garage where people had urinated in the stairwells, the odor was a familiar, almost homey one.) One of the first days Mr. Haller worked on the Behavioral Therapy Unit, he was told to take a patient named John to the library. Not knowing that there was a library at the hospital, he took John and they walked over to town and went to the public library, and then they walked back. Mr. Haller did not realize his mistake until later, and John had a wonderful time. ${ }^{19}$

The main entry hall of the center building, 2008.

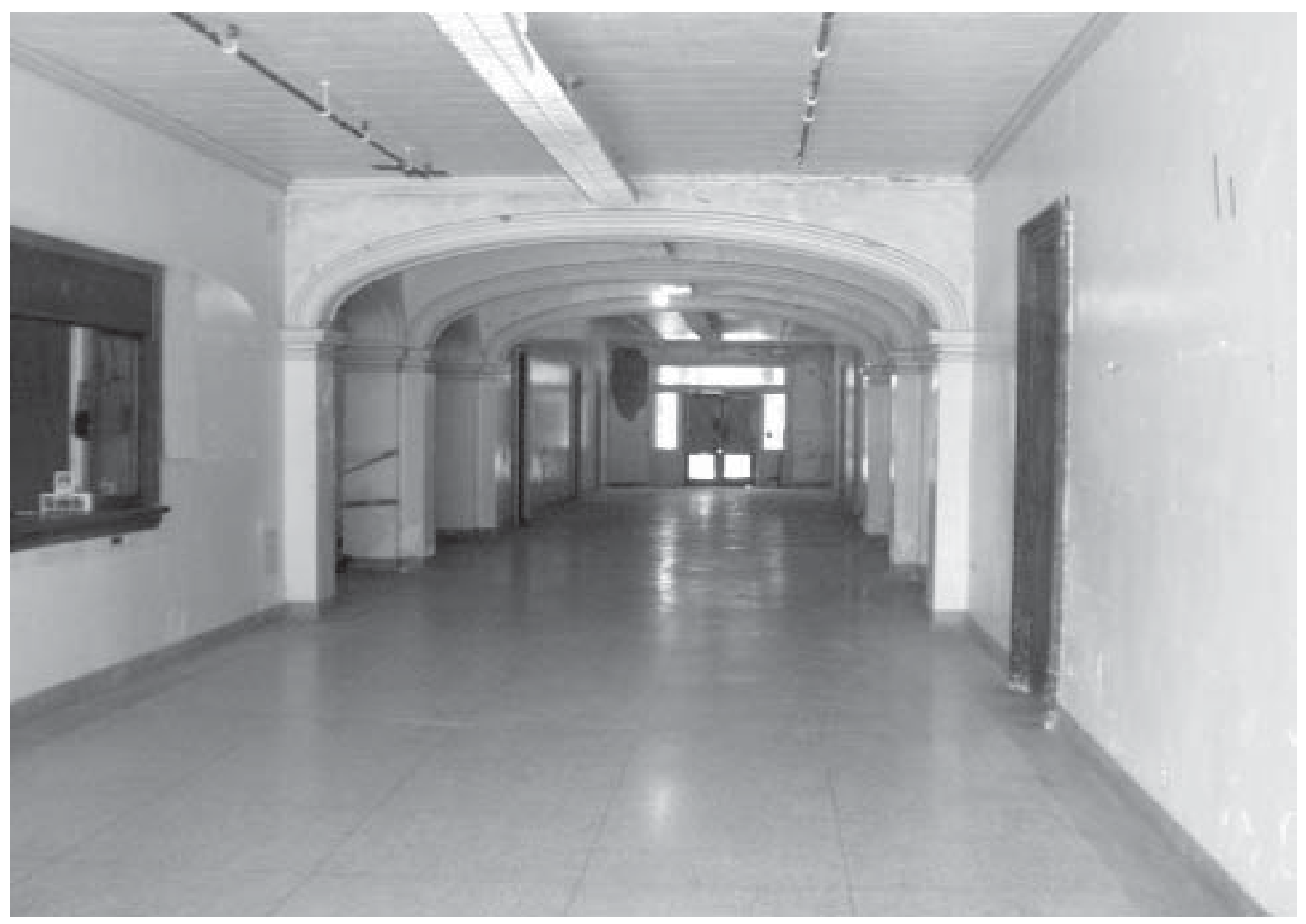


Ms. Mason, the registered nurse, found herself in the position of being the only RN on duty for her first weekend of work. The other $\mathrm{RN}$ who was expected to be there did not arrive, so Ms. Mason determined to handle things on her own. She remembered going from one building to another, trying to find her way, and at one point being paged that a girl was having a seizure. Ms. Mason opened a door, rushed up some steps, unlocked a door, and they said, "Oh, the nurse is here already!" She had surprised herself by arriving right where she was needed. ${ }^{20}$

Bill, the security guard, was taken aback to find that only two guards worked on each shift for a hospital of one thousand patients in 1976. His first day of work was on a holiday, Christmas or New Year's (he was not sure which), so he was the only guard on duty with his supervisor. He said first someone ran over a cat behind the hospital, so he went back to take care of that. Then he was paged that there was trouble on a ward. He didn't know his way around yet, so had to get directions. His supervisor met him there and informed him that they might have to move a man off this ward. Bill recalled standing by himself on the ward while his supervisor, George, went over to confer with the attendants. Bill didn't know who the problem patient was. He saw a large man approaching him, and then glanced over at his supervisor when he said, "Bill, watch out!" Bill looked back at the man and was hit right in the forehead. Bill said he had seen him coming but never dreamed he would do something like that. As Bill related,

George did try to help me. He had looked at him and said, "Well, Bob, you - " and he'd no more than said that when that big old foot just lifted him up and he went against the wall—hit his head. That was it - he was gone. [unconscious] So we fought around. Nobody helped me. I had to put this man on the groundChristmastime. We tore down the tree, we knocked over tables where they was serving food. We was all over the place. But I wasn't gonna turn loose of him-he'd done hurt me once and he wasn't going to-but anyway, I held him. I looked up and said, "Somebody'd better help me or get me some help, or I'm gonna turn him loose!" Now they got me some help. ${ }^{21}$

About an hour later Bill began to be sick. They took him to the local general hospital and found he had a concussion. He recalled, "That's when I met Dr. Pertz [a general practitioner]. He said, 'Well, you're working over there. I'll probably see you a lot.' I'll never forget that. [Bill laughed] And he was right; he got me for that, for blood clots. Dr. 
Snead worked on my knees— he sent me to Snead for that. Dislocated shoulder. Broken hands. Broken fingers. A lot of things happened over there."22 So Bill had a difficult first day, but later the man who had hit him became a friend and would come to Bill and ask to be put in seclusion if he felt an uncontrollable spell coming on. The man's parents also came to visit Bill after he received the concussion and offered to pay his hospital bill. ${ }^{23}$

One of Dr. Todt's first impressions of the hospital, when he began working there as Director of Clinical Support Services in 1992, was of meeting the most infamous patient in the hospital, a man who was known to have murdered a fellow patient and was suspected of having killed another. Dr. Todt recalled:

The first day I walked up on the unit with the Medical Director, and the guy walked up to me and looked at me with his Hannibal Lector eyes and said, "I'm gonna cut your heart out." I thought, [laughs] "Why am I here? Why am I here?" But Pat [Haynes], the Medical Director, who is a great guy, he just said, "Now, just mellow out." [laughs] OK-I took a deep breath. I was used to mentally ill people, but not someone who wanted to cut my heart out. ${ }^{24}$

\section{Dangers: "Somebody's gonna get hurt."}

Though many of the patients at Weston were harmless and easily manageable, there were those who were dangerous and difficult to handle. The housekeeper remembered being chased around a table by a patient who was yelling that she had done something to his mother. She said, "You know they'd get to thinking crasy stuff." She was also hit hard in the chest by an elderly man in a feeder chair. "Well, I was pretty new-well, I never dreamed that somebody like that would hit me- with his fist," She also recalled another time, while cleaning the floor by the hospital bed of an elderly TB patient, the woman grabbed her by the hair-'"I didn't think I'd ever get loose!" 25 She had to be rescued by another housekeeper. She also recalled that she always had to peek through a small window into a dangerous ward before unlocking it, because one time she had almost opened the door and walked right into a fight. Another time when she was coming out of a bathroom on a male ward, a patient grabbed the toilet brush off her cart: 
And they were wooden then - they were big, wooden. And I run. I just left everything there and I run. I went down and told one of the aides and he went up there. That guy got the aide down and started beating him with that thing. He had him down in the floor - that aide. He was in the fetal position and him beating him with that commode brush! So I seen what was happening, and I just had to go get some more of them. I told them, "He's up there beating the beck out of this man. You've got to come and help him!' Well, they didn't get in no hurry. No. They just took their good old time. Got up there and got him off of him. I think they didn't like the aide. And when they didn't like you, buddy, you was in-you know, if you ever needed anyone. Now that's how it was then. I don't know how it is now, but I'll tell you one thing, I liked to have them all liking me, 'cause if I ever needed help I wanted them to run! [laughs] ${ }^{26}$

This housekeeper was cleaning on a ward one day when a big man, who was in the hospital for having killed a man who had turned off his TV cable, lost his temper and began cursing and tearing things up. He picked up the TV and threw it down on a table. She said she practically ran over people trying to get out of there, and after he was subdued they set the TV back up and it still worked. She said she did not mind the actual cleaning jobs she had to do, but the difficult part was just the unpredictability of the patients on the "bad wards" where she usually had to work. ${ }^{27}$

Ms. Mason, the RN, remembered one night when she was called up to the forensic (criminal) unit where a man was complaining of chest pain. She told them to bring the man out, and she examined him but could find nothing wrong. She told the man they would keep him near the aide station and watch him. Then they discovered that the patients had expected her to come in on the ward to check this man, and had prepared to attack with pencils they had sharpened "just as sharp as they could get them," wrapped in things that they had hidden under their mattresses. They had planned to attack, steal their keys, and escape. Ms. Mason was very glad she had been wise enough not to go into the ward by herself. ${ }^{28}$ She also recalled that you could have a crisis with an employee as well as the patients. One time she received a call from an aide who had accidentally taken some Tegretol (a seizure medication) instead of Tylenol. Ms. Mason had to induce vomiting to help her. There were also many diabetics among both the patients and the staff. One night she recalled they had three different emergencies with diabetic patients. ${ }^{29}$ 
Of course, Bill, in the position of security guard, had to deal with dangerous patients. He expressed that he seldom had trouble with the actual mentally ill patients. The problems were with the alcoholics and drug addicts who were admitted, particularly on the weekend nights. Security guards did not carry weapons. There was a strict "no weapons on the grounds" rule for all law enforcement as well. They wanted no chance that a patient could ever get possession of a gun. Bill recalled once taking the admission of a man who was brought to the hospital by two friends, one of whom was a prominent Elkins politician. They were all drunk and were bringing in the one for treatment for his alcoholism. When the friends discovered that this man would not go immediately to the Alcohol Treatment Unit, a fistfight broke out. Eventually the hospital employees tossed the politician and friend out the door and down the steps. Bill said the funny thing was that the drunken man they had brought in to be admitted was just standing there throughout this fight, watching, with his ball cap cocked, and saying, "Somebody's gonna get hurt." 30 The Elkins men were prosecuted and in their trial protested that they should not be punished because they got what they deserved that day at the hospital. The violent patients were not always male. Bill remembered one particular woman who knocked him down, "just cracked me upside the jaw. I went down like I'd been shot.”31

The most dangerous occasions were when patients tried to take over a ward and escape. This happened one night when Bill was on duty. A ward of young men in their twenties, mainly alcoholics and drug addicts, attacked two of the aides on duty. Other aides hit an alarm and brought the two security guards running. Bill came in one end of the ward and Gary, the other guard, came in the other end. The patients were waiting at Gary's door and grabbed him up off his feet against the wall and were choking him. Bill ran to help, and aides rushed in also, but it was a "full-blown brawl." When the staff finally got the men subdued, they couldn't find the man they knew was the instigator. He was hiding in the seclusion room, up on the pipes by the ceiling. He must have had someone help him up there, as the ceilings were very high, but he was lying across those pipes. Three of the employees, including Bill, were taken to the hospital that night. Bill hurt his leg, another broke his ankle, and another needed stitches in his face. As Bill had run to the ward at the alarm, he had called to the aides in a women's ward to alert the city police, so they arrived to help, also. Bill got in some trouble for that because the hospital didn't want the media to hear of incidents like this, but Bill said he knew it was important to get help because there was a real chance that these patients might have escaped. ${ }^{32}$ 
There were people in the hospital who were known to have murdered people but had been determined to be insane. The housekeeper mentioned the man who had killed the TV cable man. Bill knew of one who had committed a murder in the hospital. He and another man were eating their lunch on the ward. No one knows exactly what happened, but the one apparently stabbed the other right into the brain with a butter knife. ${ }^{33}$

Some of the employees mentioned a man who was known to have committed one murder at the hospital and then was suspected of committing another several years later. This was the man who greeted Dr. Todt with, "I'm gonna cut your heart out." The housekeeper remembered how upsetting the first murder was. She and her cleaning partner arrived in the morning to one of the locked men's wards and found everything was totally quiet. They asked an aide what was going on, and he replied that one of the patients had been murdered. Two other patients had taken this man, Dan, who was a mute, back into one of the rooms and hung him. Then they took him down and put the metal leg of the bed through his head. She had to help clean up after this; the aides had cleaned some, but there was still blood on the walls and gloves and film paper on the floor from the police being there. She was extremely disturbed about this for quite some time. She had truly liked the patient who had died. The two men responsible were transferred up to the forensic unit where they stayed for several years, and then they were brought back to the same ward. She couldn't believe it. Then another patient was killed on that ward, and they suspected that one of these men had smothered him. ${ }^{34}$ From that point on he was kept with a one-on-one aide. The housekeeper reported that he was still at the Sharpe Hospital when she retired from there. Dr. Todt explained:

If patients were ruled insane, they could stay there until we deemed them to be appropriate for the community. The patient who had killed the two patients in Weston, that guy, when I met him in '92, by 1997 when I left he was no more ready to go out. That dude's mental illness was so intractable that he was on all of the new medications. He reminded me of Hannibal Lector-the look in his eyes. But we had really good people_-we had WVU down there treating him-but there was nothing they could do about him. ${ }^{35}$

No one was willing to trust this man, so even if he went home for a visit (the housekeeper mentioned he had a very nice, normal family), he had a one-on-one aide with him, a large man who could control him if necessary. They also tried a new miracle drug, 
Clozaril, which helped him some, but not that much. ${ }^{36}$ (Employees reported that the patient is still at Sharpe Hospital in 2008.)

\section{Injuries: "He wasn't hurting me really, but, he was the one who was hurting."}

Employees and patients faced some danger while working at Weston, however most did not have to deal with the most severely violent patients and so avoided much of this. Those who worked in offices could stay in their office if a fight broke out in the hallway. Those who worked in admissions had to deal with people as they were brought in, whatever their problems might be. Bill once had to chase after a young man who had been brought in while playing in a baseball game. He had taken some kind of drug and "gone crazy." They had handcuffed him on admission, but he ran. As Bill caught him, the man began kicking Bill with his cleats. Bill ended up with blood clots in his legs from that encounter. ${ }^{37}$ Bill also reported having a dislocated shoulder, three knee surgeries, and a broken leg. He said people would fall into you and dive into you. ${ }^{38}$ Dr. Todt mentioned that there were a lot of workman's compensation claims. In his first week he saw a patient who was only five feet tall, in the midst of a manic episode, fling off six very large men who were trying to control him. ${ }^{39}$

Mr. Staubly, who worked with the substance abuse patients, recalled having his glasses broken one time when he was too near a fight between patients and an elbow caught him. He also recalled once, when he was working in a psychiatric ward in the army, that a man who was going through detox feared that people were trying to kill him, and he bit Mr. Staubly. One of his colleagues later asked him how he remained so calm when this happened, and Mr. Staubly had replied, "Well, he wasn't hurting me really, but he was the one that was hurting." ${ }^{40}$ Mental hospital employees had a remarkable capacity for empathy.

When I asked the aide, Mrs. Lowther, if she had ever been hurt, she replied, "No, just pinched and scratched and hit." ${ }^{\prime 1}$ Most of us would consider being pinched, scratched, and hit being hurt. Ms. Mason, the nurse, recalled having to give a man an injection, and he, in turn, kicked her in the chest. Another man hit her in the nose when she was trying to help him cut up his meat. She laughed about this because exactly a year later to the day the same man hit her in the nose again when they were helping him back in bed after hip surgery. She said she apparently reminded him of a wife or daughter that he did not like. ${ }^{42}$ 


\section{Most serious problems: "There was really a major lack of funding."}

When asked about the most serious problems they or the institution faced when they were working at the hospital, it was interesting that no one seemed to think the patients or the patient population were the most serious problem. The housekeeper was the only one who expressed that the dangers were her biggest concern, and she, of course, was working in the difficult wards and never knew what to expect from the patients. ${ }^{43} \mathrm{Mrs}$. Lowther, the aide, was bothered most by the stigma associated with working at the hospital. She said people acted "like it was the plague." She said, "I don't know that I was ever ashamed of working there, I don't think I was, but a lot of people were." ${ }^{44}$ She went on to say that the stigma lessened over time and was not as bad in later years, particularly as new administrators worked on getting the patients out into the community more.

Bill, the security guard, felt that his problems dealing with the administration were the most difficult aspect of his work. He worked as a union representative, part of the CWA, Communication Workers of America, and complained that he wished they had had better management. ${ }^{45}$ Ms. Mason, the RN, also expressed that Charleston was more of a problem than the patients. She felt the government did not understand what was really going on at Weston, what their problems were, and she thought some of their regulations and paperwork was burdensome. ${ }^{46} \mathrm{Mr}$. Staubly, the counselor, saw the most difficult part of his work as being the disagreements among staff as to the best treatment for patients. Though there were a lot of good relationships within their unit, there were some personality issues and conflicts over the best approaches to use. ${ }^{47}$

Dr. Todt discussed the need for more therapy and different kinds of treatment for patients at the hospital, and less reliance on psychotropic medications. He also emphasized the need for better funding, both of hospitals and community mental health centers. He recognized the need for advocates to speak up for the mentally ill, or otherwise they would receive very little attention. The stigma of mental illness, and the belief that it is just the "panhandlers on the street" make it difficult to secure money for the mentally ill. Dr. Todt said, "There was really a major lack of funding, not only in this state, but in all the other states." ${ }^{48}$ 
Bill, the security guard, sometimes felt that the administration did not have the best interest of the workers in mind. He had to petition for the addition of a few more security guards, and "got in trouble" when he felt compelled to call the local city police to assist if they had problems at the hospital. He said Charleston was concerned about news of any trouble at the institution getting out to the media, which he noted that it rarely did. Bill also expressed concern over alcoholics and drug addicts being sometimes placed in general wards with the other patients. They could take advantage of them or be abusive and he felt they should be separated from the general population of the hospital. ${ }^{49}$

Bill related a story that particularly frustrated him in attempts to communicate with the hospital administrator in the 1980s. One Friday, Bill was called up to the forensics unit because there were rumors and a "bad feeling," a feeling of tension there- that something was going to happen. Bill requested additional staff on forensic for the weekend in case of trouble. The administrator refused, questioning Bill's judgment, and would not approve any overtime. As Bill feared, that weekend a terrible fight broke out on the forensic unit, not on Bill's shift, but he was called in to see the aftermath. Four employees were sent to the local hospital and admitted, and two patients had to be transported to West Virginia University Hospital in Morgantown. The one who had instigated the fight had his jaw area and teeth all broken. Because he was known to have murdered people (remember the one with the butter knife), the University insisted on his being restrained and guarded by two guards at all times. Bill was assigned to be in the operating room with the man when he had his first surgery. The man was kept in Morgantown for over a month, with two guards on three shifts, so Bill said, "You can imagine the cost to the state. And they could have just added a couple of people to each shift for that weekend and we would have been fine." ${ }^{50}$ Later this patient ended up suing the hospital for his injuries, won his suit, and was eventually released. The aides who had fought him quit their jobs because they felt certain they were going to be fired. Bill tried to stand up for them against accusations of abuse, stating that they had fought for their lives, but there was question as to why this patient had been so seriously injured. Bill was especially angered when the state mental health director declared that, "We pay these health service workers for what they do and what happens to them. We pay you to work here and take this abuse." Bill was so angry he quit working at the hospital for several years. ${ }^{51}$ 


\section{The facilities: "A bit stuffy and stenchy, but clean."}

The buildings, though old, were kept clean and maintained in the last few decades of the hospital's existence. The state hired large housekeeping and maintenance staffs by then. Walking through the halls of the main building seems rather dark and gloomy now, but the patients' rooms all have large windows and allow in an abundance of light. Thomas Kirkbride had wanted patients to have plenty of light and air. The "parlor" areas on each ward also have large windows. The dormitory rooms on the ends of each ward were the original dining rooms. These later evolved into dorm style rooms crowded with beds when other buildings were constructed for dining. In the last years, these rooms were equipped with big fans in some of the windows and designated as smoking rooms. Patient advocates believed that the patients should be allowed to smoke at the hospital. After the stress of being admitted to a mental hospital, it seemed too cruel to then also take away their cigarettes. The only rooms in the main building that have small windows and are not so light are the tiny rooms on the fourth floor, originally built for employees. They have small dormer style windows that were apparently added in the 1930s, according to photographs of the hospital. (Perhaps when the building was repaired after the fire?)

Fourth floor rooms originally built for employees. This area was also the Behavioral Therapy Unit for a time. (Photo in 2008)

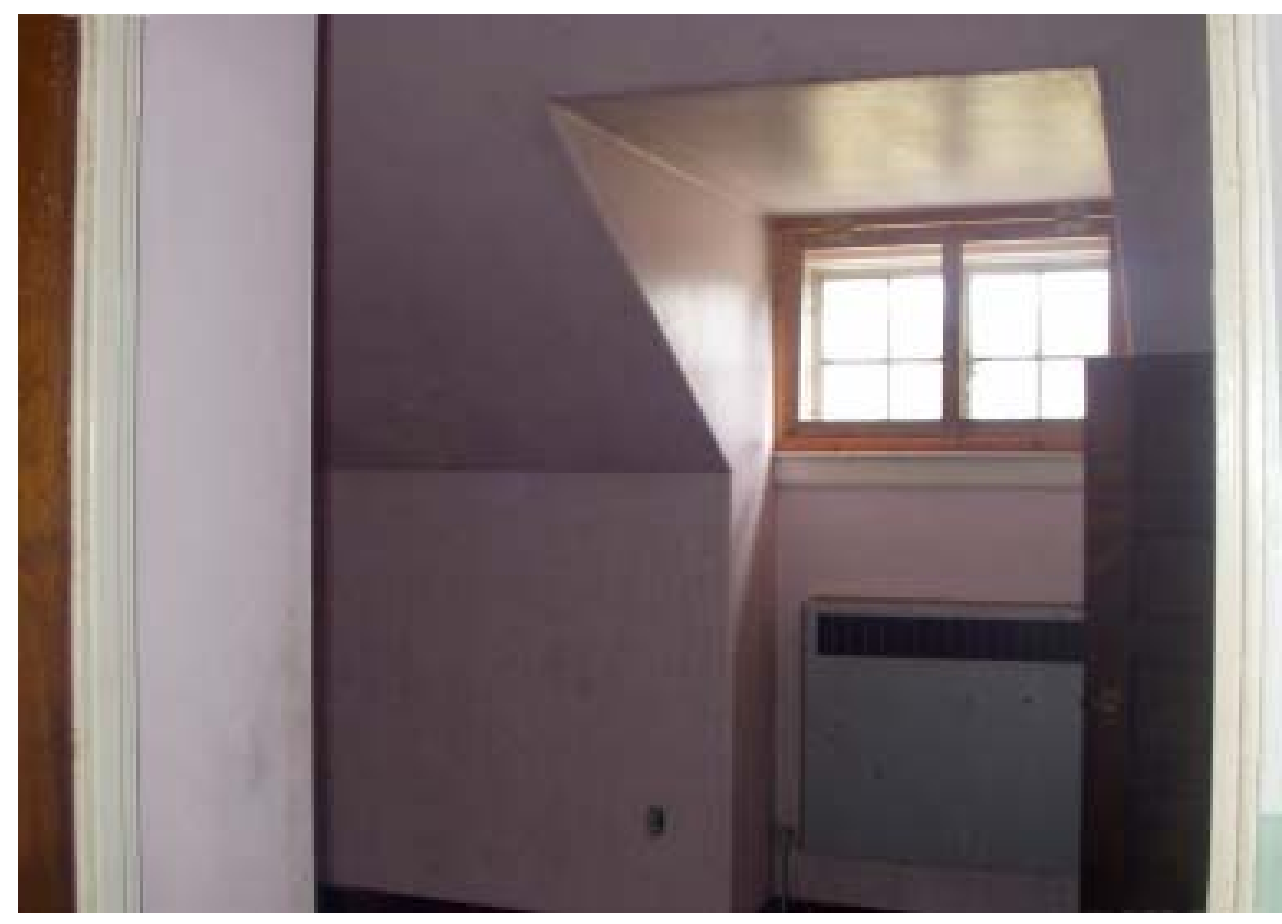


The interviewees remembered different concerns about the facilities at Weston. Mrs. White, the church group volunteer, laughed about riding the "terrible, scary elevator. "When those doors banged shut, you were just afraid you would not ever get out of that elevator. It went clickedy, clunk, clunk, clunk. [laughs] It was ancient-had been there for years and years and years. We would have been better off going up steps because we were all afraid of it. And it was huge, and we all got in it, with our tray of food-with our cart." 52 (On a recent tour of the hospital, the tour guide, a former hospital employee, related that she had "once had the privilege of being stuck in that elevator" as we walked past it.)

Bill, the security guard, worried a bit about the basement of the main building. He said the lighting was not well maintained because no one wanted to take care of things down there. There were lights there, but not enough. He had to venture down there occasionally to look for a missing patient. The basements, with dirt floors, were also covered with a thick dust, several inches thick, and Bill was concerned about what he was walking through and kicking up over his feet and breathing. Bill also worried over the roaches. He said, "At the big hospital we never did get rid of roaches. All they done [spraying] was make them bigger and badder. You could step on them and your foot would move. Now you think I'm kidding. I've had that happen, I don't kid you." 53

Mr. Haller, the student worker, said the buildings were a bit stuffy and stenchy, but clean. He saw no signs of neglect. The patients were kept clean. If someone wet themselves or urinated on the floor, someone would come along and clean up. "There was always some kind of mopping going on," he remembered. ${ }^{54}$ There was a urine smell in the geriatric wards that was unavoidable due to all of the patients who had to have portable toilets or urinals next to their chair or bed. Mr. Haller mentioned that the mentally retarded building (on the left as you face the main building) was more pleasant than it appeared from the outside. It had "cages" on each end, which were porches closed in totally with wire mesh. He would play games in those porches with the patients because it was less stuffy there in the summertime. ${ }^{55}$

One aspect of living in the institution that should not be overlooked was the lack of privacy for the patients and their lack of personal space and possessions. Patients were assigned a room with at least one other patient, even in the period of lower population. In the crowded years every room and even hallways had patient beds. There was, at one time, no partitioning walls between toilets. The shower rooms consisted of several showerheads 
along a wall with no partitions. Several patients had to shower side by side with an aide watching them to make sure they shampooed their hair and all. Items such as shampoo were handed out directly into the patient's hand. Even toilet paper was given out as patients needed to go to the bathroom. Clothing was handed out one outfit at a time. Few patients had any personal possessions, and if they did they carried them around with them in a bag. The beds most patients slept in were quite small, not wide at all, and with thin mattresses. (This information was shared on a March 2008 tour of the hospital, led by guide Cathy Turner, a former employee.)

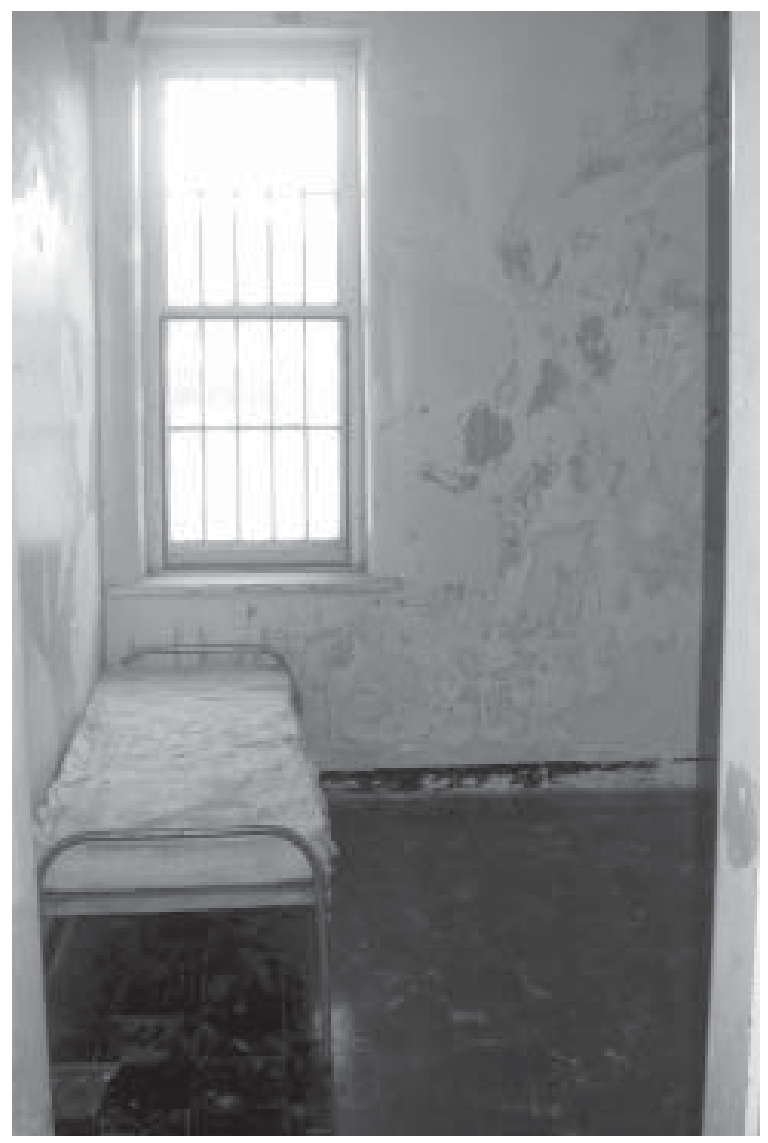

A patient's former room and bed in 2008. The room had been painted a pastel yellow and had abundant light, but this small bed was typical of patients' accommodations.

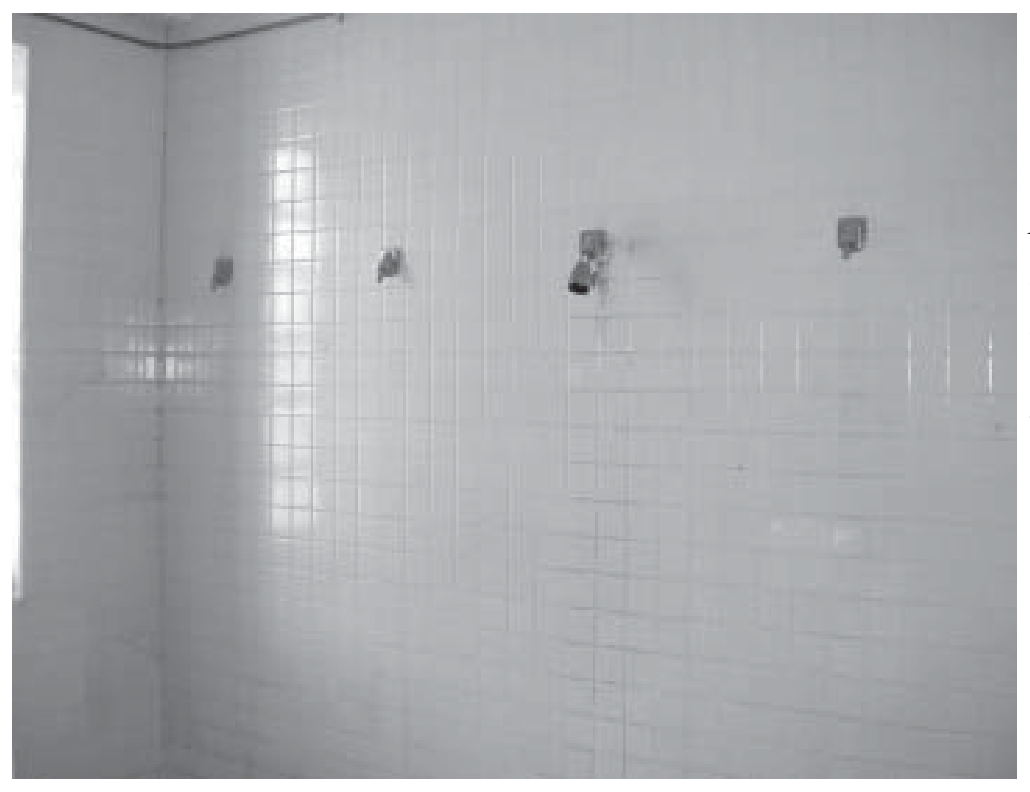

A typical shower room. Patients had no privacy and were observed by an aide while showering. 


\section{Fellow employees: "What can we do to support you?"}

All of the employees interviewed expressed closeness to their fellow workers. They were often like family after having worked together for many years. The housekeeper worked with the same man for years and years, and one time he rescued her when she was cleaning the bathroom in a male ward. A patient had come in and grabbed her from behind and started "trying to feel all over." Her partner came in, who was not a large man, and grabbed him by the shirt and slammed him up against the wall. Then the aides arrived to assist them. ${ }^{56}$

Several of the employees mentioned admiring fellow employees. Mr. Haller talked about what a wonderful person Gerry Kiddy was, the director of the recreation department. The other employees there, Mary Metz and Linda Collins, completed what was a "wonderful department." He described Gerry as bringing "a lot of compassion and energy to that department." ${ }^{57}$ He described the staff he worked with as being very helpful, having an attitude of, "What can we do to support you?"58

Maintaining a sense of humor seemed to be important to all of them as well. Ms. Mason mentioned an LPN, who was a friend of hers, who used to get a kick out of starting a rumor at the beginning of the night shift, "Did you hear that.....?" and then laughing at how it was all over the hospital by morning. She was careful not to say, "I heard......" but "Did you hear.....?" as she started her rumors. ${ }^{59} \mathrm{Mr}$. Staubly also noted the importance of humor in the ATU as well. He said they had a host of interesting characters there to deal with, and he remembered when one director came up with the idea that their unit should be called "Fusion House," meaning an integrated program using divergent approaches; the "wise guys" instead called it "Confusion House." 60

\section{The illnesses: "I don't know if she was manic or what she was, but they got her calmed down."}

The patients at Weston suffered from a variety of illnesses such as schizophrenia, bipolar disorder, depression, and dementia. Ms. Mason, the RN, mentioned that many patients suffered from seizures, and Mr. Haller recalled that some patients wore helmets 
to prevent injury if they had a seizure. Patients often had seizures in the rec hall, and Mr. Haller said this was quite frightening. He also recalled one patient, Beverly, who would have severe manic episodes. "When she got the most manic ever, she was riding a mop handle up and down the hallway, and they were trying to get her. That memory had some vividness, somehow, that Beverly was just all out of control. Then when she was sad, she would be just despondent. So she had a rough time." Her family was still interested in her, though, and would take her home for a time. ${ }^{61}$

Patients at Weston ranged in age from older teens to the elderly. Mr. Staubly said the Alcohol Treatment Unit patients ranged from 18-year-olds to those in their sixties or older. ${ }^{62}$ The new admissions were sometimes very upset upon their arrival at the hospital. Mrs. Haller remembered a schoolteacher being brought into the main hall who was just yelling and cursing, "I never heard such language in all my life, so I don't know if she was manic or what she was, but they got her calmed down." ${ }^{63} \mathrm{Mr}$. Staubly, the counselor, told of one story he had heard:

A deputy was escorting a patient who had been committed to the hospital up here, and when they arrived at the hospital the patient had-I don't know whether he had been handcuffed or what-but he got the better of the deputy. Hit the deputy in the head, I think. But anyway, the deputy, after a while, was saying, "I brought a patient up here, I'm a deputy sheriff." And they said, “That's all right. You'll feel better after treatment." [laughs] And so there were stories where you can't tell the patient from the professional people, sometimes. ${ }^{64}$

Bill, as a security guard, had to help with the admission of new patients. They had to strip the patient and get him into the institution's clothes. Some patients, understandably, rebelled. He recalled:

We got so many drug addicts and alcoholics. That was your trouble. Very seldom did you have mentally ill people—as a matter of fact, I can think of none- that a truly mentally ill person would cause you any problems. It was drug addicts that was hopped up on drugs, or those boozers that they'd bring in there. They didn't have no place to put them. They couldn't put them in jail by law. So we got them. And that's where you got your-I looked at them different than I did than a truly mentally ill person. ${ }^{65}$ 
Mr. Staubly noted that patients might be put back in the hospital by relatives when they did not need to be. He recalled some admissions into the Alcohol Treatment Unit:

We had one person out of Morgantown, for instance, that the wife would call up and say, "He's drinking again," and they would send the person back [to Weston]. And the community counselor would say they'd had a lot of contact with this person, and in this particular case, they thought the wife just wanted to get him out of the house. [laughs] She would claim that he was drinking again. I imagine that there were probably times when people would even offer somebody a drink so they could find an excuse to get them back into the hospital.

There were a lot of stories, particularly before my time, that families would decide, odd man out — there was somebody in the family they wanted to get rid of — so they'd call up and say, "This person is crazy; take them to the hospital." It's sometimes a financial thing. There was one person at the hospital, and she was out and around a lot and we got to know her-in fact, some people thought that she was on the staff. She was frequently in the front hall and was really with it, but the story was that her family was fairly wealthy. And I guess there was some conflict over money, and so they got her committed. And back in those days, people could be there a lifetime. ${ }^{66}$

\section{Recreation department: Dancing the polka with Belva}

The recreation department was an important and valued part of the hospital staff. There was little entertainment at the hospital, just a television in each lounge and occasional activities brought in by volunteer groups, so the activities provided by the rec department were welcomed by many of the patients. Mr. Haller told about many of the rec department duties. He would return to the hospital in the evenings to help with the dances. He danced the polka with the patients and spun the records, usually in the large ballroom and occasionally outside. Belva, in particular, was one patient he remembered who was a good dancer. She liked the polka. Many of the patients just sat, rocked back and forth, and smoked, but the dances were well attended and enjoyed. ${ }^{67}$ Movies were also a regular activity for those who were well enough to attend. And the recreation department was always circulating among the better wards with games and activities. It would have been helpful to have had a larger recreation department in order to reach more patients more 
often, alleviating the regular staff and entertaining the patients, but they connected with as much of the population as they could.

The recreation department took patients on trips to state parks, to the mall in Clarksburg, on fishing outings at Stonecoal Lake, and elsewhere. In the 1950s, the local Episcopal Church held dances at their community room, White Hall, for some of the patients. Mr. Haller remembered some of the field trips. One was on a bus to Watters Smith State Park with the Behavioral Therapy Unit. At the children's playground, one of the women fell off the spinning merry-go-round. It was spinning over and over her, but she wasn't hurt; he just remembered the potential for her being injured. Riding on the bus, they began to smell flesh and realized one of the patients was burning his arm with a cigarette. Otherwise they enjoyed the outing. ${ }^{68}$

In Mr. Haller's work with the recreation department, they circulated among the better wards and engaged patients in games and activities. In the geriatric wards, they handed out candy and just talked to the patients. Mr. Haller remembered:

And with them we'd just go and sit. Like the woman I remember from your ward is one of my favorite state hospital stories because she's the one who told about the time that she was cooking in the kitchen and her husband walked in, and she said, "I was so surprised I fell right between the bean kettle and the teapot. I didn't expect to see him again—he'd been dead for fifteen years!' [laughs] So I loved everything about that story-I loved the bean kettle and the teapot. ${ }^{69}$

Mr. Haller acknowledged that his work at the hospital helped him develop empathetic listening skills, which have been valuable throughout his life. Mr. Haller enjoyed playing cards with some of the women:

Belva, the euchre player, she was very talented. And the people on her ward, some of those elderly women who were playing cards were talented. Now the cards, when you played with Belva, would be disrupted a little bit by Belva who would, in the middle of card playing, would come up behind Mullooly and this fellow Steve [other student workers] and kiss them on the back of the neck. And she had this big red lipstick that she smeared on, and then she'd come and kiss them on the neck and call them "Freddy," because that was her husband-Freddy. "You're my husband Freddy." Except for me, because I was named Tom, and her father had been named Tom, so she spared me the kisses. So that was good. ${ }^{70}$ 
Mr. Haller also recalled taking the patients outdoors:

Every now and then we'd go outside to play games. So I remember volleyball. But see, I would remember volleyball with this guy Larry, who also had a nice joy about him. Larry couldn't hit a ball over a net, or catch a ball, or return a ball. I don't think he ever had that skill, so I mean volleyball was-you'd hit the ball over the net, it would drop. Pick the ball up and hit the ball over the net and it would drop. [laughs] So that was the nature of it. But Larry liked to run after the ball, and he would run - he would run and flap his arms. He liked running and getting the ball. So people liked sportlike things. ${ }^{71}$

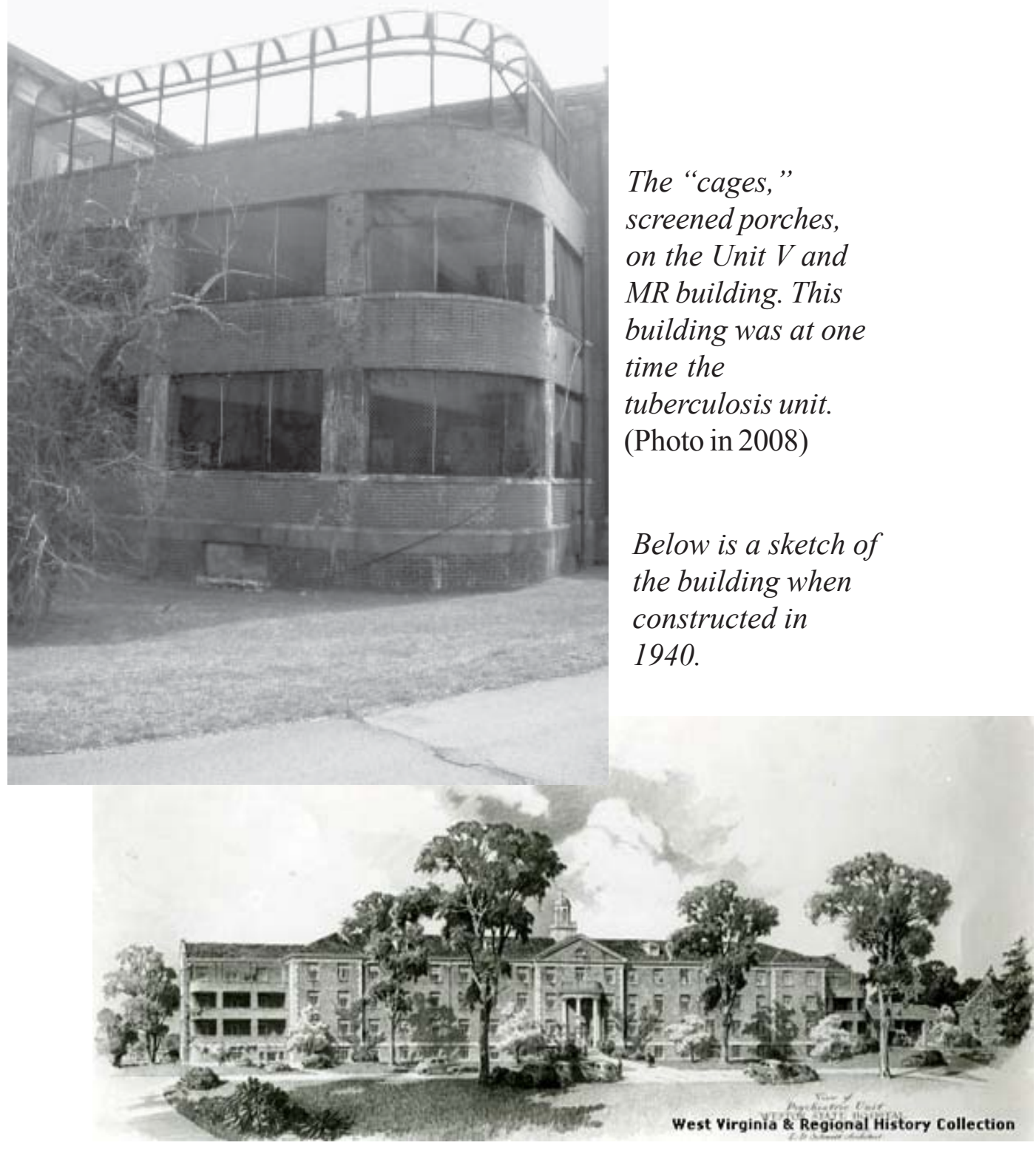




\section{Patients amusing themselves: "Hey, you got a cigarette?"}

Most of the patients did not get outside of the buildings very often during the sixties and seventies. Mrs. Lowther, the aide, said the only exercise they got was to walk to the cafeteria. When the housekeeper went to work in the 1970s, she said they did not have anything for the patients to do. They just lay around. She believed they would have been better behaved if they had been busy. She recalled one patient who occupied himself by picking off the asbestos insulation that was wrapped around the pipes and eating it. She mentioned this to an aide, concerned about the man's health, but the aide responded that it hadn't killed him yet. She knew another patient that caught roaches and ate them. He would run down the hall chasing one, catch it, pop it into his mouth alive, and then pull the legs out and throw them down because that was the part he would not eat. ${ }^{72}$ Less ambitious patients spent a good deal of time watching television. Mr. Haller noted the irony of once seeing a room full of patients watching a soap opera on TV in which a character was committing suicide in a mental institution. ${ }^{73}$

Patients developed a variety of ways to amuse themselves. Some patients enjoyed asking for items from the canteen, a small store for patients and staff. A patient might give an aide a few cents to go purchase an item, and then thirty minutes later ask them to go for another small item, and so on throughout the shift. ${ }^{74} \mathrm{Ms}$. Mason, the nurse, recalled some patients faking seizures to try to obtain Valium. She said sometimes they would try to act like they were having a seizure and have one eye opened, watching her. ${ }^{75} \mathrm{Mr}$. Haller, with the rec department, also mentioned a certain patient, a large and muscular African American man, who was a good spades player. He was supposed to be famous for "bedding everyone in the barn." 76 None of the employees seemed to know of any birth control being distributed at the hospital. Only one could remember a pregnancy, and the girl's family took the baby home, and then the girl eventually returned home as well. ${ }^{77}$ The 1951 Board of Control report listed six deliveries in the hospital from 1948 to $1951 .^{78}$ In the 1970s there was discussion of sterilizing a mentally ill young woman who was known to be meeting men in the old laundry building.

Volunteers from the community, such as church groups, often came to the hospital to visit patients or provide games like bingo or other activities. Priests and other speakers from the community would come and talk to the alcohol and substance abuse patients, and some of these speakers were in recovery themselves. Mrs. White remembered visiting the hospital with a Methodist women's group. They were first assigned to a male ward 
where there was one man who would not wear clothes. Mrs. White remembered her first time there. She was pouring the coffee when the naked man came over and sat down right behind her. "I was a little uneasy," she laughed. Soon they were assigned to visit a women's ward instead. The patients were always glad to see them. The ladies brought cookies, coffee, cigarettes, and bananas, and sat and talked with them. Some of the women did this for years and years and got to know many of the patients. There were a few younger patients in the ward, but most were elderly. Mrs. White remembered one time when one of the church ladies who liked to watch a particular soap opera in the afternoon went over to the TV, which no one was watching, and turned the channel to her program. One of the patients started screaming, so she quickly changed it back. A friend of Mrs. White's remembered going to visit a ward with a community group. She was upset because all the women were barefoot, but she was told if they gave them shoes and socks they just threw them out the windows. ${ }^{79}$

As far as patient amusements went, all of the employees mentioned tobacco use. The housekeeper remembered her disgust at seeing patients pick up already-used wads of tobacco out of spittoon cans and popping them into their mouths. She also commented on all the ashes and cigarette butts on the floors. Smoking was allowed in the building for many years, and most of the floors were tile by this era. She said the bottoms of the patients' feet would be just totally black from the ashes. She had frequently caught her big wide mop on fire by sweeping up the still-burning cigarette butts. ${ }^{80}$ Patients were always asking for cigarettes. Cigarettes were used as a reward for good behavior, as a thank-you if a patient was helpful, and were available at the canteen. The state provided tobacco, rolling papers, and rolling machines for the aides to roll cigarettes for the ones who had no money to buy any at the canteen. Mrs. Lowther, the aide, described the rolling machine: "It's a little machine, by hand. It's got, like a little canvas thing over it, and there's a little lever. You put the little sheet of paper in, and put the tobacco on it, then rolled it up, and licked it [laughs], and handed to the patient. Can you imagine?" [laughs] ${ }^{81}$ Mr. Haller, with the recreation department, said he did so much cigarette rolling as well. The rec department always carried cigarettes and candy around to the wards. People were always clamoring for "cidarettes." ${ }^{22}$ Dr. Todt said, "That was part of the treatment program, if you did the appropriate things, you would get a cigarette. Oh, my god, these people were always after a cigarette. 'Hey, you got a cigarette?' We had essentially taught them how to smoke." ${ }^{\prime 83}$ By the time he was there in the nineties, smoking had to be done outside, and you would 
enter the main building through a cloud of smoke, and people were always asking for a cigarette. $^{84}$

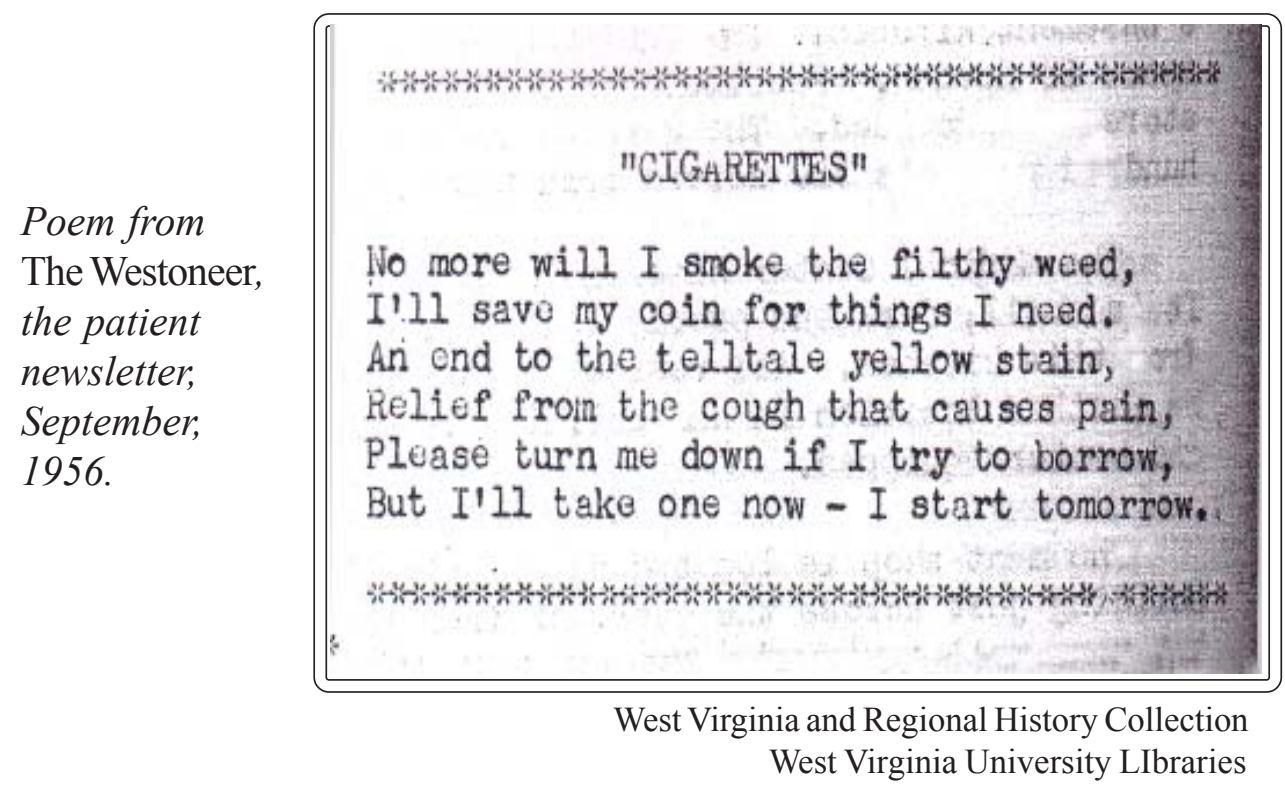

\section{Managing behavior: "Talking them down."}

Managing patient behavior was a challenge at times. All of the employees had to learn how to deal with patients who began to get upset, for whatever reason. Learning to "talk a patient down" was a skill everyone had to acquire. Good behavior might be rewarded with a grounds pass, a cigarette, or money for a soda or coffee. Patients who became very out of control or violent were restrained or put in seclusion. They might need to be medicated to calm them down.

Patients who were put in seclusion could be extremely agitated. The housekeeper remembered one who was put in a temporary seclusion room after a fight and then proceeded to yell and kick at the door. He was kicking it out at the bottom, and she was shaking while she cleaned up the ward, afraid that he was going to come out of there. ${ }^{85}$ Sometimes patients could be brought to the hospital while extremely violent, but then calm down immediately with some medication. Ms. Mason, the nurse, remembered one man being brought in who had torn up his nice house and was totally out of control. They put him in seclusion in forensics. After being given the medication Haldol, he settled down and was moved to an open ward the next day. Ms. Mason could not believe it when 
she came back on duty and found that he was on an open ward, but she went to talk to him and he was totally sensible. His wife did not press charges and he went back home. ${ }^{86} \mathrm{Mrs}$. Lowther, the aide, remembered a person once being put in seclusion and then taking the bed apart and pushing parts of it up against the door. No one could get in to him. She said they had a terrible time, but finally a doctor who had good rapport with him "talked him down" and got him to move the bed. ${ }^{87}$ Later they did not have any furniture but just a mattress in seclusion.

\section{Escapes: "Hey, did you know this guy was missing?"}

Stories of patients escaping from Weston State Hospital were common. The complex had no border fence other than an ornamental four-foot high iron fence on two sides of the lawn. It was quite easy for a patient to wander off if they were not on a locked ward. Mrs. White, who raised her family in Weston, recalled how they used to announce on the local radio station whenever "an inmate" had escaped from "the asylum." She would lock all the doors of their house just in case. One time her husband, Ross, was working out in the front yard and talked to a man who was walking up the street. The man continued on, and Ross then came in and called the hospital because he felt certain the man was a patient. ${ }^{88} \mathrm{Mrs}$. White also recalled when one of her friends, a state hospital nurse, was eating in a local restaurant one day and jumped up to run out and retrieve one of her patients that she saw walking down the street.

Ms. Mason, the RN, was driving to visit her sister one cold day and saw a patient walking along the road at Horner, several miles outside of town. She recounted, "So I just pulled over to the side of the road and I said, 'Come on, get in the car where it's nice and warm.' So I just took this guy back and went in the hospital with him. And I said, 'Hey, did you know this guy was missing?' and they said, 'Well, we've been calling all over town. Where did you get him?"' The hospital had had an all points bulletin out on him, and they were surprised that she had found him and returned him by herself. ${ }^{89}$

Mr. Staubly noted that patients would frequently elope from the alcohol and substance abuse unit if they were upset or unable to deal with their situation. The staff would then call their local mental health center to see if they could make contact with these people, offer support, and get them back into treatment. He noted that some of the patients from Randolph County would return to a place they called "the old stone house," 
near Elkins. These were abandoned houses by the quarries, and there they would get back into drinking and their addiction, and often eventually return to the hospital. Mr. Staubly thought a few had set the record at returning at least ten times. ${ }^{90}$

Mrs. Lowther, the aide, remembered having to chase a female escapee up a hill where she lives now, several miles west of the hospital. The woman had been missing just that day, so she must have hitchhiked out there. Someone had spotted her and called the hospital, so Mrs. Lowther and another aide were sent to retrieve her. The woman ran up the hill away from them, through briers and brush, but was cooperative once they finally caught her. Mrs. Lowther recalled having to do this while wearing her uniform, which was a white skirt and hose. (Aides had to perform multiple tasks, including cleaning, bathing patients, and everything else in those uniforms.) Female patients from the state hospital were easily identifiable by the simple cotton dresses they wore, with printed material. The men were less obvious, with khaki pants and plain shirts, though at that time they stamped their unit number on the back of the men's shirts. ${ }^{91}$

Occasionally there would be an attempt at a breakout by some of the more criminal patients, and incidents such as that of Clarence and his sheets. Sometimes escapees could be truly dangerous. Lawrence Chapman, in Weston Hospital, Vol. I, had photocopied two articles from local newspapers about escapees from the hospital. One was a May 1958 article from the Weston Democrat, reporting that a murderer had escaped. He was a 35-yearold man who was in the hospital for having killed his parents with a mattock. He escaped while being walked in the security area. He had climbed the fence and fled barefoot at 2:30 in the afternoon. He was known to like the woods and had eluded capture after murdering his parents by staying in the woods for some time. Another article was from the Weston Independent in August of 1967, when nine men had escaped. The article described the capture of a 22-year-old, one of the last of the group to be apprehended. He had hidden on the second floor of an elderly couple's house while they were working outside. The older man discovered him and grabbed his gun. They struggled and the patient got the gun. It went off but did not harm anyone, and the patient assured the wife who rushed into the room that he would never want to harm them. He then tied up the couple and demanded the keys to their Jeep. He got as far west as Camden, five miles from Weston, when the Jeep died. Two unsuspecting people there helped him get it started again. Then when he reached the community of Pickle Street, a few miles further on, he was apprehended by the police. $^{92}$ 


\section{A haven for others: "He'd beat them back to the hospital."}

On the other hand, there were many patients for whom the hospital was a haven they did not want to leave. Mrs. Lowther, the aide, said you could understand why some of them wanted to stay there, if they did not have a home to return to, or if their home situation was so bad. She said, "We had some that, you know, you could understand why they were there - their family, or situation, you could just understand, and wonder what you would do in that kind of a situation. Some didn't want to go back, or wanted to get away from it all. Yes, the hospital was a refuge for some of them. And there were some who didn't have money to go into private nursing homes. ${ }^{\prime 93}$ Ms. Mason, the nurse, noted that the patients had the security of regular meals, a roof over their heads, and free clothing. It was a better situation for some of them than they would have had out in society. ${ }^{94}$ Mr. Staubly mentioned that the substance abuse unit saw many people who had to return to the hospital time and again. It was not that they were happy to return, but often they were feeling so bad, physically and mentally, that they knew they had to get back into treatment, and some of them multiple times. He said, "When they got physically ill, and it was difficult for them to keep on with their addiction, they'd just come back in and, I think, be glad to get to feeling better. They were just physically ill and miserable." 95

There was a female patient in the 1970s who suffered from bipolar disorder. When she was not having a manic episode, she seemed very normal and was quite intelligent. She seemed to have resigned herself to staying in the hospital, however, by the fact that she had her bank account checks printed with her address as: Unit I, Ward 8, Weston State Hospital. One of the people in the social work office remarked, "Now that is institutionalization." This woman was, however, sometimes so manic that they had to force her into a straitjacket because she became so out of control.

There was one patient named Sam who was noted for returning to the hospital whenever he was taken back to his home in his community. Not only did he return, but he would get back to the hospital before the staff who drove him home did. The housekeeper remembered, "They could take him and release him, I mean release him, take him home. He would beat them back. He would beat the people back that took him tohonestly, he would hitchhike and beat them back! 'Cause they'd stop and eat, or stop, you know." "Sam was well behaved and would not hurt anyone, but he did not want to leave the hospital. He would hitchhike back to the hospital and arrive before the staff returned. 
And this happened several times. The drivers would laugh about it and say that they had just stopped to eat, and he beat them back to the hospital. ${ }^{97}$

\section{Suicides: "That was very, very, very sad."}

One depressing aspect of life at the institution was the occasional suicide. It was difficult to prevent suicide among the very disturbed patients at the Weston hospital. The employees noted that if someone really wants to kill himself he will find a way to do it. One problem at Weston was the high ceilings with exposed pipes running along them through many of the patients' rooms. Bill, the security guard, told of several suicides. One was a beautiful young girl, a dentist's daughter, who secured a town pass and went over and bought lighter fluid. She then doused herself and her bed and set herself on fire. When the firemen got in to her, thinking she was dead, she opened her eyes and said, "I didn't do a very good job, did I?" She was rushed to the burn center in Pittsburgh but died a few days later. One young man once took off running from one of the hospital dances. Bill tried to pursue him but could not catch him before he jumped off the bridge into the river in front of the hospital. Bill could not get to him and he drowned. Bill felt terrible about that because he was unable to run fast enough due to his leg injuries. He gave up security work shortly after that. ${ }^{98}$

West Virginiia and Reagional History Collection West Virginia University Libraries

Footbridge crossing the West Fork River in front of the hospital. This photo was taken early in the twentieth century, but there still is a small bridge leading over to town.

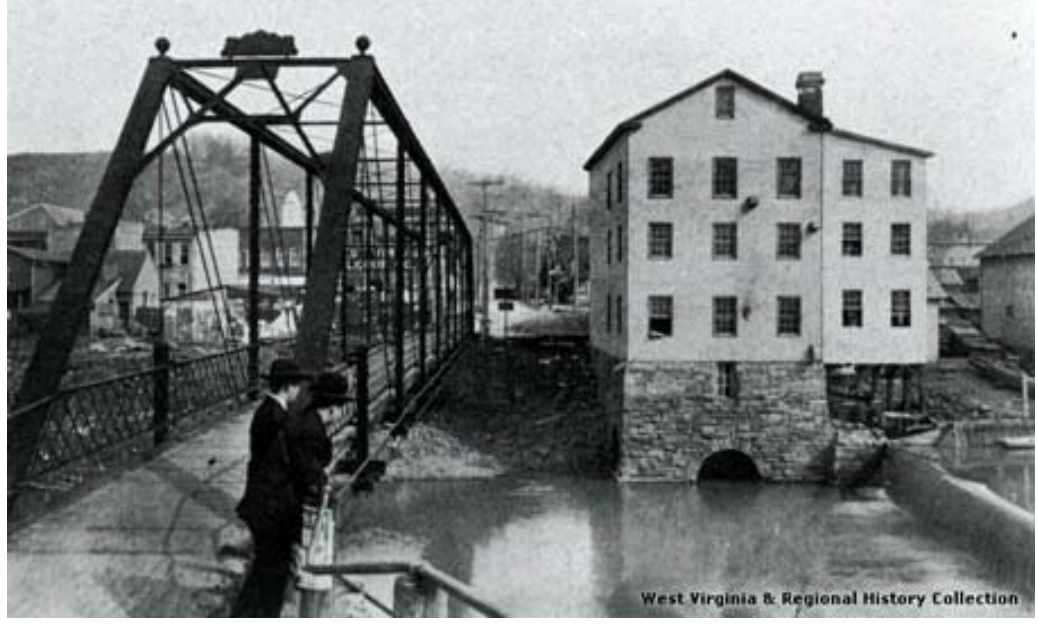


Dr. Todt remembered the last suicide at the Weston hospital, which was distressing to him. A young man was scheduled for discharge that day. The staff believed that they had him set up well in his community. He apparently made a phone call or received a phone call that day at about 12:40. By 1:30 they found he had taken a sheet and thrown it over the pipe and hanged himself in his room. Dr. Todt said:

The social workers had done a good job of getting him placed, and got him some support, but he got this weird phone call and we could never figure out what the phone call was- either he received it or made it. He talked to somebody, and then he committed suicide. So that was very, very, very sad. It was the last suicide in the hospital. I felt really bad about it. That's why we were anxious to get to the new hospital. ${ }^{99}$

Dr. Todt was hoping the new Sharpe Hospital would be much more suicide proof. It may be better, but employees reported that patients there manage to attempt suicide, too. One case mentioned was the man who attempted suicide by cutting his throat with a metal towel rack, though he did not die. Another hung himself on the back of a door with a sheet. Another was caught trying to hang himself with his belt, but a nurse revived him with CPR. ${ }^{100}$

Several of the interviewees mentioned problems at the new Sharpe Hospital. Dr. Todt said the construction was not well done. A base of concrete that was to be poured three inches thick was only one inch thick. Leaks in various places resulted in "sick building syndrome" after six months. Many of the staff were getting ill, and they brought in NIOSH, who discovered they had Legionella, Legionnaire's Disease, in the air conditioning system from the standing water there. Because of leaks, there was water and mold underneath the carpets as well. However, Dr. Todt said that the one thing that was much better at the new hospital was that it was more suicide proof. ${ }^{101}$ Mrs. Lowther, the aide, said she thought the atmosphere at Sharpe was so much better because it was so much lighter and brighter and modern. She said that everything worked there, and the physical work was not as difficult for her. There were fewer patients, and a better staff-patient ratio, so everything was improved. ${ }^{102}$ 
Pipes running along the ceiling of some of the patient rooms were always a suicide hazard.

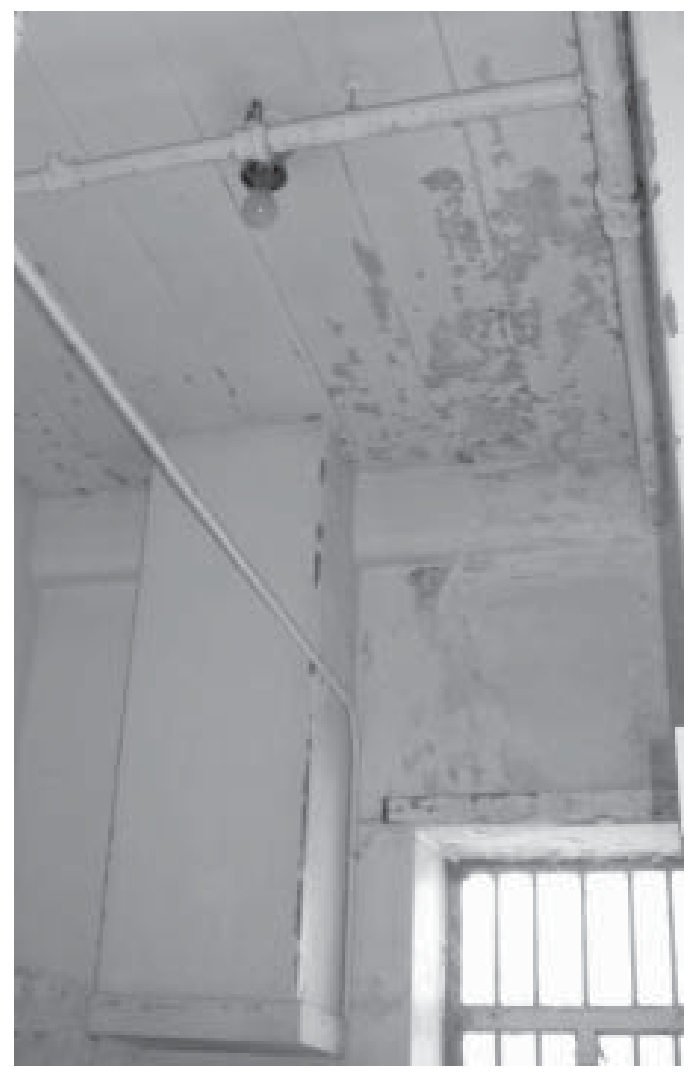

\section{The town of Weston: "To tend to a community that needs your help like that, you know, requires a great deal of giving."}

The history of the town of Weston is inseparable from that of the state hospital. The citizens were a part of the hospital as employees, as volunteers, as friends and relatives of patients. Many people who lived in Weston worked at the hospital, and many of these for their entire careers. Some employees lived in surrounding communities or counties and traveled to the hospital daily. Mrs. Lowther remembered in the 1960s and 1970s that some of the apartments in the hospital were occupied by people from other counties who went home only on the weekends. ${ }^{103}$ Mrs. Lowther talked about people's attitudes toward the hospital when she began working there, the stigma associated with it. She understood that average people did not understand mental illness_-"if you have never dealt with it, been involved in it, it is scary." 104 She felt that people became more accepting over time, especially as the hospital began a policy of taking patients out into the community more. They would take them to the movies, or shopping in town, or take a busload down to the mall in Clarksburg. ${ }^{105}$ Mrs. White mentioned seeing "the rickety old bus" go by in town. "And 
we'd say, 'Well, there's the state hospital bus.' And they'd be waving to people as they went along." 106 Another anecdote Mrs. White remembered illustrates the fear people have of the mentally ill if they are not used to being around them. Mrs. White told about taking her college-aged daughter (my sister) over to the hospital to apply for a summer job-to teach sewing. While her daughter went inside, she sat in the car, parked in front of the main building. Although it was a warm day, she kept the windows rolled up and the doors locked. Men came up and tapped on the window asking for money. She just shook her head at them. While she sat there, she watched a young man climbing up a wire screen over a window. He was yelling and climbing "just like a monkey." Mrs. White was hoping her daughter did not land a job. ${ }^{107}$

The economic impact of the hospital on the town was considerable. Even though employees did not receive generous salaries, they had steady employment. Until the last decade or so they spent much of their money in Weston at various local businesses. Mrs. White mentioned that many people were employed at the hospital and at the four glass factories in town. Weston has suffered as those closed. ${ }^{108}$ Mrs. Haller agreed, and mentioned a few interactions between the hospital and the town that were interesting. She recalled one summer in the 1950s when her boss was dealing with the dilemma of how to help the town out during a severe drought. She remembered that Lake Riley, a local recreational lake, was drained, and thought that the hospital had shared some water also from its reservoir. She also noted that the ashes and cinders from the boiler at the hospital were used to treat the streets of Weston in snowy weather. She also recalled one of the impacts of deinstitutionalization - that when the hospital closed, all the pigeons that used to live around the hospital and survive on tidbits there moved over to the town. ${ }^{109}$ Mr. Haller, the student employee, commented on the influence of the hospital on the town:

I think that the community, in a way-Weston-having that hospital in the middle of town, really had a culture of caring. And I feel that when the hospital moved outside of town that it took some of that soul, some of that purpose - and then took it away and hid it —off on the hill and it's not part of the community. It could be that it's - that's just an illusion or whatever, but - to tend to a community that needs your help like that, you know, requires a great deal of giving. But then when you're doing that giving, there is sort of a nice energy around it. ${ }^{110}$ 


\section{A culture of caring: "Try to put yourself in their shoes."}

There was certainly a culture of caring within Weston State Hospital, particularly among long-term employees. All of the former employees remembered some of the patients and fellow employees fondly. Bill, the security guard, remembered "so many good patients" that he missed, and how with the truly mentally ill, "You could take them by the hand, you could put your arm around their shoulder; they'd go right with you anywhere you wanted to go, as a rule. Some of them wouldn't, but very few of them."111 Bill fondly remembered a patient he called Red:

We had a big black guy, when I first went to work there. And I called him "Red," don't ask me why. He'd been a bad guy at one time, they said, and my boss, Stan, said, "Bill, if you make friends with him, he'll be your friend 'til the day he dies." And I got to talking to him and stuff. He was big, probably 300 pounds, six-six, something like that. He was a big man.

But out underneath this kitchen area here, they'd sit and play poker, three or four of them. And they wasn't supposed to. And they stayed on me all the time to have the guards break that up-but it was something for them to do. It's not like they was playing for big bucks. And never no trouble. But that's how I got to know him.

And two or three years I dealt with him, and I could do anything with him. When he'd get mean, like he was gonna blow up, he come to me. "Bill, let's do something." I'd say, "OK, we can do that." And I'd put him in the hole, get him medication-he asked to be secluded-_Help me. Help me." And we'd just walk him right down, tell the nurse, and when they'd see me coming they'd know. They'd give whatever medication they'd give him for two or three days, and the next thing you know, he's out there playing poker again. But he died, and that killed me. I just couldn't believe it, that he was gone. He was so healthy looking. A heart attack. But I had a lot of good patients over there that I missed. But they died off little by little and I think that took a toll on me-the older patients, who was there when I first began. ${ }^{112}$

Mr. Staubly, the case manager, also discussed the closeness of people in the alcohol and substance abuse unit. Many of the people, the staff members, were either in recovery themselves or had a relative with abuse problems. They could relate to each other in many ways. Many of them remained in touch with each other years later. He said: 
We had a number of people who kept in touch with each other afterwards. Of course, those in recovery that came back and worked on the unit would keep in touch with each other through AA or NA. There's kind of a closeness that, maybe, people with other problems don't have. Certainly the support group is one of the key things in recovery. And the atmosphere was a lot easier to deal with because of bumor. There's a lot of humor in recovery. There are a lot of very colorful characters [laughs] that we worked with over the years. And we had a joke about how our clients were not always being honest with us: "How can you tell if an alcoholic is lying to you? - If his lips are moving." 113

Dr. Todt remembered enjoying going around and talking to the patients on the wards. He would sit down amongst the patients and ask them how the food was, how things were on the unit, and all. And of course everyone was always asking, "Hey, do you have a cigarette?" Dr. Todt also expressed how saddened he was over the suicide that occurred when he was there- the young man who was to be released that day. He also discussed how distressing it was to have the staff upset when changes were being made as they transitioned into the new hospital.

Mr. Haller, the student, commented, "I liked the residents tremendously. I liked working with the people who liked the residents. And there were some people who didn't like them and didn't treat them so well, or whatever. But I didn't like those people then, as much. But I think in our community, you know, it was all very supportive. What can we do? It's almost like consulting work now. What can we do to support you?"114 Mr. Haller exchanged letters with one of the patients for a while. She was a young woman who seemed to be quite normal. He contributed a photocopy of a letter he received from her after working there one summer. He had talked to her often and taken her for a walk, as she referred to it, "around the park." (Mr. Haller thought it was interesting that she referred to the lawn as a park. Much of the lawn still has its huge old trees. The intention of Dr. Kirkbride had been to have a place of refuge for patients, surrounded by a park.) Mr. Haller laughed about his level of comfort with mentally ill people, even now, twenty-five years later. He was describing a patient named Eddie: 
Eddie was from Wheeling _-'WHEELing, WEST VirginYA!" [laughs] "Eddie from WHEELing, WEST VirginYA!" and then there was something about how he was involved in a race track, "There's a RACE track ......!" But it would be this GRAND THROWING your VOICE kind of SENTENCES! He was young, maybe in his thirties. But he'd be in your face. That was another thing. The sense of personal space among residents is often different than that of real people_-'real' people [laughs]—supposedly normal people who have learned about space.

But for years after working there, street people-it's almost like they would seek me out. I remember once when I was living in Ohio, and this woman came up to me, and is like inches away from me, and said, "I'm going to a smorgasbord?" And I remember the person I was with was like-what?? I was like, "OH! Good for you!" So I love all that. And I probably, I didn't continue-my field wasn't any kind of social services. I think it was probably the wages that kept me away from that, not that the wages now-[deep voice] "You make poor wages in the social services, you should be a teacher!" [laughs] "Go work adjunct with the university." [laughs] ${ }^{115}$

Mr. Haller recalled going to see the movie "One Flew Over the Cuckoo's Nest" at the time he worked at the hospital. As the audience laughed at the mentally ill patients depicted in the film, he said it really bothered him—-hit a raw nerve. He said he realized that the movie was just actors portraying the mentally ill, but somehow it really troubled him. Mr. Haller felt the audience had no understanding. Their laughter was very upsetting to him, and his eyes filled with tears at the memory of it. Mr. Haller's imitations of patients at Weston, their voices and behaviors, though somewhat humorous, were delivered in a very affectionate way. Mr. Haller remains fond and protective of the patients and their memories. ${ }^{116}$

Ms. Mason, the RN, remembered spending a good deal of time calming patients at night. She also said she often helped patients get to sleep by offering them something like a stool softener or other placebo and while letting them believe they were receiving a sleeping aid; they would settle down and go to sleep. She remembered one night when the aides were having all kinds of problems with two women on one of the wards. The aides called her for assistance, and Ms. Mason told the two women if they wanted to leave they could. She invited them to come outside with her and have a cigarette, and if they wanted to run they could run. That was enough to calm them down, and after a smoke and some conversation they went back to the ward. Ms. Mason said you had to think about what they 
Pagel

August 28,1979

Dear Tom:

Hows your day today? Irr. doing just fine for right now. I miss being with you. I still remember the last diay when we took $A$ Walk around the park. I was going to write to you sooner but I got very busy. How's your classes? Im still thinking About going to Charlestonbut I dor't know for sure yet. I just want you to know that Im thinking About you. Im still going to my Classes now. I hope you will write back to me. How is every body down there? now one of my oldess sisker had a baky boy then a fter a couple weeks later my other sister had a baby boy too. I have a etr cold now. I hope your thingring About me too. I hape I get to see you Again some gald day And when I do I hope we can go for a walk Aroundagain. I have going outside now. How is your family Tom. I hope we can see each other before I get out of weston Hospital. Will its Almost time for my Classes so see ya soon Thom.

From A friend Alwhys Debra Jean í. Weston state Hospital weston west Vinginia ward F. $\quad 26452$

A letter from a patient, received by Thom Haller, student recreation department employee, in the 1970s. (Courtesy of Thom Haller) 
were going through — their family situations or whatever their problems were. She said, "The best way to do it was to try to put yourself in their shoes. You could come down to earth with them." 117 She also explained how working at the state hospital was different from other nursing work, in that they were more involved with the patients and developed a kind of intuition that helped them care for these people. She said she and Hazel, her LPN friend, had had discussions about this. They remembered when they happened to go in and check on the girl who had slid down in her restraints, and the time Ms. Mason did not go into the forensic ward to check on the man with the supposed heart problem, or the time she found her way right to the girl having a seizure. She reflected:

What tells you to do these things? In a general hospital you work your eight hours and you go home and that's it. You would give medicines or whatever you were supposed to do. If you worked surgery, you had your eight hours in and that was it. But I guess over here you used intuition sometimes. Well, I don't know. I don't know what told us to check on her. Wouldn't that have been awful if she had died in those restraints? And her sister being an LPN working there? But you do kind of wonder, I guess you get so you can sense certain things. ${ }^{118}$

Mrs. Lowther described relationships between patients and between patients and staff. She said that even when the patients of all types of diagnoses shared a ward, they usually managed to get along very well with each other. She said they understood each other and knew that they were there for a reason and tried to help each other. When I commented that I thought it took a special kind of person to do that kind of work, she replied, "I think we're all called to do what we like, you know? I enjoyed it, yes. I met a lot of people. And the patients were-some of them were just so good. Good patients, good people." ${ }^{119}$ Mrs. Lowther said she became very close to some of the people she worked with as well as some of the patients. She laughed about how the doctors would get mad at the aides for being so welcoming when familiar patients, after being discharged, arrived back at the hospital. She said, "-Like it was something that the patient could control. And maybe they could, I don't know. But, some of them, when they came back it was like old home week. 'Where have you been? What have you been doing? I've missed you! Tell me what's been going on.' And the doctors would get mad at us, then, because we were so glad to see them." [laughs] $]^{120}$ 


\section{Attitudes: "A good place to make an investment of energy."}

The attitudes of the employees who were interviewed for this paper were very positive. Their general level of job satisfaction seemed high considering the difficulty of the work there. (I realize they were reflecting on times past and may have given me a rosier picture than they would have if I had interviewed them as they came off their shift on an average Tuesday in 1983.) But the comments they made in their remembrances convey an overall positive attitude about the hospital, even as they recognized the many problems there. All the employees had developed empathy, listening skills, and an ability to calm upset patients. Mr. Haller mentioned life lessons he learned from the patients. He said he recently had a negative thought come into his head, and he said to himself, "Oh, that's all I need are those damned Lurtys in my head.” He realized he hadn't thought of the Lurtys for some time, but that he had learned about them at the hospital. One of the elderly ladies had, at one point in her life, been tied to a truck and dragged behind it down the road by the Lurtys, and "now they were in her head causing all kinds of consternation." Mr. Haller continued, "I guess I ended up using the Lurtys as symptomatic of dark thoughts I didn't necessarily need to carry around in my head - a lesson in positive living offered by a schizophrenic." 121 Mr. Haller reflected on other people's attitudes toward the institution:

It's always so easy to put down the hospital. If they're from another community, and you say you are from Weston, and they say, "Oh, ha, ha, ha, ha, ha! There's a hospital—you crazy people." So it's easy to put you down, but then to participate in it was reallywonderful people there, working there. I just loved-I loved the people. There weren't people I did not like-I mean, grounds people you'd like, people at the canteen, people certainly in my department and around, aides and stuff. It was weird work, but everybody kind of knew it was really weird work. [laughs] So then everybody was all kind of a little weird, so that was all interesting to me. It was good training for organizational behavior. [laughs] ${ }^{122}$

Mr. Haller truly enjoyed the company of the people he met at the hospital, and felt that it was a good place to make an investment of energy. Dr. Todt, working through the transition to the new hospital, explained what was most satisfying to him: 
The staff really embraced JCHL [the Joint Commission standards]. They really took it on. And the fun was working with the staff and seeing the hospital change. They became more professional. They became more patient oriented. And they really bought into it. That was the fun stuff. And to see patients getting out and actually patients better. And we did studies that - we were finding that the recidivism rate in many cases was coming down. They weren't going out and coming back in; it wasn't becoming a revolving door. But the staff were really wonderful, except for the ten percent that weren't - the abusive ones. They [the others] were good. But they were committed, they were caring, they were bright, they just-as Gordon and I discovered, for one thing they just didn't have the training. They weren't given the proper direction to get them to where they needed to be. You know, given the proper direction — and the same thing happened at Hopemont [Hospital, facility for elderly mentally ill]. I would send anybody to Hopemont because I know the staff up there. I've never seen a more caring staff, that makes so little money, but-you can see it today, whatever a patient needs, they were [snap] right there. Go into another nursing home. Well, they'll tell you they have more staff at Hopemont, but it's a different nature of staff. They never once not wanted to improve patient care. So that was the best part of it-seeing the hospital change. ${ }^{123}$

Ms. Mason, the nurse, said she really enjoyed interacting with the patients and the staff. She said sometimes it was surprising what you could do with an agitated person, sometimes by just listening to them. If you sat down and talked to them for fifteen minutes they would calm down and go back to bed. She also remembered a time when one of the aides was ill with cancer and in the United Hospital Center for some time. She sent him several cards and told people who were going to see him to tell him hello. After a time he passed away. One day his widow came in and wanted to know who Shirley Mason was because she wanted to thank her for her kindness to her husband. Ms. Mason said it she felt it was important to be nice to the staff and patients. Ms. Mason said she found her work rewarding and that she enjoyed it. ${ }^{124}$ Mrs. Lowther, the aide, also said she enjoyed her work. She laughed that she must have enjoyed it because though she is retired now, after over thirty years there, she still volunteers. She said, "I had a good time with the patients, but the people that I worked with - they became family. And I must have enjoyed it because I still volunteer up at Sharpe. I enjoyed it."125

Bill, the security guard, said that with all his years there, he could not say that he regretted any of it. He said he wished the management could have been better and that 
some things had been different, but overall he liked his work there. He did not feel as comfortable in the new hospital as he did in the old—he said he didn't like change. And he felt the new hospital was not as secure and substantial. As an example, he noted how a patient could go through a wall at the new hospital if they wanted to by kicking through the drywall boards with which the walls were constructed. ${ }^{126}$ Though retired, Bill continues to work with elderly people in the community, providing assistance to them in their homes.

Mr. Staubly discussed how the people he worked with in the ATU were challenging, but interesting people, all kinds of backgrounds and all kinds of talents. Some of them were very sharp people, and many had all sorts of responsible jobs. Mr. Staubly said a number of the patients were very good at recreational and craft activities. He still has a quilt, some ceramics, and other items that some of them had made. ${ }^{127}$ The ATU was phased out before the closing of the Weston hospital, and Mr. Staubly went to work for one of the community mental health centers, Summit Center, in Clarksburg. He still keeps in touch with many of the people he worked with at Weston. He is also active in community work such as Habitat for Humanity and said that someone had recently contacted him from Sharpe Hospital wanting to involve patients in Habitat projects.

The housekeeper now works caring for elderly people who need assistance in their homes. She said she has it easy now, compared to her years at the hospital. But she also said that despite the difficulties, her work at the hospital became routine. It all was just a normal workday to her after a while, and she had a lot of fond memories of people from the hospital. I noticed she had a painting of the Weston Hospital hanging on the wall of her living room. She said it had been given to her as a gift when she retired after twenty-seven years at Weston and Sharpe. ${ }^{128}$

\section{Closing the mental institutions: "They just don't have the community support system."}

When I asked the former employees their opinion about the closing of the huge mental hospitals like Weston, most expressed concern that the people with mental problems might not be receiving enough care through community mental health programs. 
Many mental patients have trouble keeping up with taking medications and keeping appointments with mental health centers, and therefore lose touch with caregivers.

Mrs. Lowther mentioned that for the mental patients who are out on the street, it might not be so good that there are no more institutions, but the focus is now on trying to get them back out into the community. ${ }^{129}$ Ms. Mason, the RN, felt that the institutions should have remained open to provide places of care for those who need it. She believed some of the crimes that have happened, such as the Virginia Tech school shooting, might have been prevented if these people had a place to be watched over and where they could consult with mental health personnel. "They could have been more comfortable and taken off the streets." 130

Mrs. Haller, who had worked at the hospital in the 1950s, thought it was probably better that the hospital closed because it had been such a "dumping ground" for families to put someone they no longer wanted around, but acknowledged that patients had gained more rights in recent decades. "An awful lot of those people, with medication, you see, are fine, as long as they take it. Some of them do need supervision. But I don't know that there's any need for places as big as this. I don't think they need that. Maybe more specialized?" ${ }^{\prime 31}$ Dr. Todt related an anecdote expressing the downside of the institutions:

Well, there was a study done once. Two psychologists entered a mental hospital as patients. Only the superintendent knew who they really were. And after two months, their IQ's had dropped and they were having hallucinations. Living in stress and fear was really affecting them. Even in your sleep you know you can be attacked. If people don't have deep sleep, REM sleep, for four or five days, they will start to hallucinate. These were stressful places. ${ }^{132}$

Mr. Haller said he was "not a fan of deinstitutionalization." He went on to say that he understood that institutions had a bad reputation, whether they were feared or were being made fun of. He also mentioned his interest in mental health centers in his area. He contributes to a halfway house in his neighborhood in Washington, D.C., and he purchases a lot of art from an occupational therapy organization that markets the art of people who have mental disabilities. ${ }^{133}$ 
Mr. Staubly commented:

I think the general idea [of deinstitutionalization] was good, but the follow up, as is so often the case, is not. They had better support at one time, and now it's one of those things where they just don't have the community support system. Mental health centers and addiction programs, I think, aren't nearly as strong as they used to be-lack of funding and lack of commitment in general. The large institutions often were just warehousing patients. They need rehab and support and follow up. ${ }^{134}$

It almost seems as though society's attermpts to care for the mentally ill have run a full cycle. Once again the mentally ill are in the community, with varying degrees of care. Many are in jails, as they were when Dorothea Dix began campaigning for them in the 1840s. Many are not able to keep up with continuing their medication and therapy without adequate supervision, but the establishment of huge mental institutions like Weston State Hospital is unlikely to occur again.

$* * * * * * * * * * * * * * * * * * * * * * * *$

These interviewees, the former employees of Weston State Hospital, are the people who did our work for us. These are the people who cared for the elderly, the unwanted, the difficult, the impossible. They took care of society's problems with minimal pay. It was certainly not all pleasant and loving. Some of the patients were difficult, violent, and frightening. But most were not, and warm relationships developed between many of the staff and patients. In recent decades the patients received better therapy and overall patient care. Of course these interviews are just a few voices out of the many who worked at the hospital, but the memories of their experiences provide us with considerable insight into life at the hospital in the last few decades of its existence. A thank you is in order to them for sharing their reminiscences and for their years of dedicated service to the most vulnerable people in our society. 
${ }^{1}$ Michael Todt, interview with Kim Jacks, November 1, 2007, 1-4.

${ }^{2}$ Ruth Lowther, interview with Kim Jacks, November 9, 2007, 1-2,4.

${ }^{3}$ Ruth Lowther interview, 12.

${ }^{4}$ Shirley Mason, interview with Kim Jacks, December 13, 2007, 7-8, 12.

${ }^{5}$ Security guard, interview with Kim Jacks, January 8, 2008, 5, 10.

${ }^{6}$ Security guard interview, 2.

${ }^{7}$ Karl Staubly, interview with Kim Jacks, November 10, 2007, 7.

${ }^{8}$ Karl Staubly interview, 4-5.

${ }^{9}$ Thom Haller, interview with Kim Jacks, December 20, 2007, 4, 14.

${ }^{10}$ Thom Haller interview, 15.

${ }^{11}$ Anonymous housekeeper, interview with Kim Jacks, January 10, 2008, 10, 13.

${ }^{12}$ Anonymous housekeeper interview, 24.

${ }^{13}$ Mildred Haller, interview with Kim Jacks, February 8, 2007, 15.

${ }^{14}$ Richard L. Lael, Barbara Brazos, and Margot Ford McMillen, Evolution of a Missouri Asylum: Fulton State Hospital, 1851-2006 (Columbia, Missouri: University of Missouri Press, 2007), 97.

${ }^{15}$ The American Experience: The Lobotomist, program transcript, Boston: Public Broadcasting Service, WGBH, 2007 [internet]; available from http://www.pbs.org/wgbh/amex/lobotomist/program/pt.html, accessed 22 January 2008, 10.

${ }^{16}$ Jean White, interview with Kim Jacks, February 8, 2008, 1, 4.

${ }^{17}$ Jean White interview, 3-4.

${ }^{18}$ Thom Haller interview, 2.

${ }^{19}$ Ibid, 2, 4.

${ }^{20}$ Shirley Mason interview, 2- 3.

${ }^{21}$ Security guard interview, 3, 23-24.

${ }^{22}$ Ibid., 24.

23 Ibid.

${ }^{24}$ Michael Todt interview, 11.

${ }^{25}$ Anonymous housekeeper interview, 4, 8, 14.

${ }^{26}$ Ibid, 14.

${ }^{27} \mathrm{Ibid}, 15,19$.

${ }^{28}$ Shirley Mason interview, 8-9.

${ }^{29}$ Ibid., 15-16.

${ }^{30}$ Security guard interview, 7-10.

${ }^{31}$ Ibid, 25.

${ }^{32}$ Ibid, 11-12.

${ }^{33}$ Ibid, 17.

${ }^{34}$ Anonymous housekeeper interview, 5-6.

${ }^{35}$ Michael Todt interview, 10.

${ }^{36}$ Ibid., 28.

${ }^{37}$ Security guard interview, 8 .

${ }^{38}$ Ibid., 11.

${ }^{39}$ Michael Todt interview, 18-19.

${ }^{40}$ Karl Staubly interview, 16.

${ }^{41}$ Ruth Lowther interview, 27.

${ }^{42}$ Shirley Mason interview, 18.

${ }^{43}$ Anonymous housekeeper interview, 19.

${ }^{44}$ Ruth Lowther interview, 11.

${ }^{45}$ Security guard interview, 20.

${ }^{46}$ Shirley Mason interview, 13-14.

${ }^{47}$ Karl Staubly interview, 11.

${ }^{48}$ Michael Todt interview, 7-9.

${ }^{49}$ Security guard interview, 10. 
${ }^{50}$ Ibid., 17.

${ }^{51}$ Ibid., 15-17.

52 Jean White interview, 1, 3.

${ }^{53}$ Security guard interview, 20.

${ }^{54}$ Thom Haller interview, 16.

${ }^{55}$ Ibid., 16.

${ }^{56}$ Anonymous housekeeper interview, 21.

${ }^{57}$ Thom Haller interview, 6.

${ }^{58}$ Ibid., 18.

${ }^{59}$ Shirley Mason interview, 26.

${ }^{60}$ Karl Staubly interview, 17.

${ }^{61}$ Thom Haller interview, 4-5, 13.

${ }^{62}$ Karl Staubly interview, 20.

${ }^{63}$ Mildred Haller interview, 8.

${ }^{64}$ Karl Staubly interview, 22.

${ }^{65}$ Security guard interview, 6-7.

${ }^{66}$ Karl Staubly interview, 10.

${ }^{67}$ Thom Haller interview, 13-14.

${ }^{68}$ Ibid., 14.

${ }^{69}$ Ibid., 9.

${ }^{70}$ Ibid., 12.

${ }^{71}$ Ibid., 15.

${ }^{72}$ Anonymous housekeeper interview, 8-9.

${ }^{73}$ Thom Haller interview, 18.

${ }^{74}$ Ruth Lowther interview, 4, 7.

${ }^{75}$ Shirley Mason interview, 10.

${ }^{76}$ Thom Haller interview, 12.

${ }^{77}$ Ruth Lowther interview, 23.

${ }^{78}$ Board of Control Report 1948-1951, 31.

${ }^{79}$ Jean White interview, 1-2, 10.

${ }^{80}$ Anonymous housekeeper interview, 8-9.

${ }^{81}$ Ruth Lowther interview, 6.

${ }^{82}$ Thom Haller interview, 8.

${ }^{83}$ Michael Todt interview, 11.

${ }^{84}$ Ibid., 10.

${ }^{85}$ Anonymous housekeeper interview, 15.

${ }^{86}$ Shirley Mason interview, 18.

${ }^{87}$ Ruth Lowther interview, 18.

${ }^{88}$ Jean White interview, 7-8.

${ }^{89}$ Shirley Mason interview, 23-24.

${ }^{90}$ Karl Staubly interview, 9.

${ }^{91}$ Ruth Lowther interview, 14.

${ }^{92}$ Lawrence Chapman, History of Weston Hospital, Vol. 1 (Weston, WV: by the author, 1988), 94.

${ }^{93}$ Ruth Lowther interview, 16.

${ }^{94}$ Shirley Mason interview, 19.

${ }^{95}$ Karl Staubly interview, 13.

${ }^{96}$ Anonymous housekeeper interview, 23.

${ }^{97}$ Ibid., 23-24.

${ }^{98}$ Security guard interview, 21-22.

${ }^{99}$ Michael Todt interview, 16-17.

${ }^{100}$ Anonymous housekeeper interview, 11.

${ }^{101}$ Ibid., 15-16.

${ }^{102}$ Ruth Lowther interview, $23=24$.

${ }^{103}$ Ibid., 21. 
${ }^{104}$ Ibid., 11.

${ }^{105}$ Ibid., 11.

${ }^{106}$ Jean White interview, 8 .

${ }^{107}$ Ibid., 3-4, 8 .

${ }^{108}$ Jean White interview, 9.

${ }^{109}$ Mildred Haller interview, 7, 16.

${ }^{110}$ Thom Haller interview, 18.

${ }^{111}$ Security guard interview, 25 .

${ }^{112}$ Ibid., 23-24.

${ }^{113}$ Karl Staubly interview, 11-12, 24.

${ }^{114}$ Thom Haller interview, 18.

${ }^{115}$ Ibid., 19.

${ }^{116}$ Ibid., 21-22.

${ }^{117}$ Shirley Mason interview, 15, 17.

${ }^{118}$ Ibid., 25.

${ }^{119}$ Ruth Lowther interview, 25.

${ }^{120}$ Ibid., 12.

${ }^{121}$ Thom Haller interview, 22.

${ }^{122}$ Ibid., 19, 22.

${ }^{123}$ Michael Todt interview, 25-26.

${ }^{124}$ Shirley Mason interview, 14-15, 25.

${ }^{125}$ Ruth Lowther interview, 12,

${ }^{126}$ Security guard interview, 20.

${ }^{127}$ Karl Staubly interview, 15.

${ }^{128}$ Anonymous housekeeper interview, 25-26.

${ }^{129}$ Ruth Lowther interview, 18.

${ }^{130}$ Shirley Mason interview, 10.

${ }^{131}$ Mildred Haller interview, 21.

${ }^{132}$ Michael Todt interview, 29.

${ }^{133}$ Thom Haller interview, 20-21.

${ }^{134}$ Karl Staubly interview, 23 


\section{Bibliography}

Primary sources:

Biennial Report of the Directors and Superintendent of the West Virginia Hospital for the Insane for the Years 1875 and 1876. Wheeling, WV: John W. Gentry, Printer, 1876.

Biennial Report of the Directors and Superintendent of the West Virginia Hospital for the Insane for the Years 1879 and 1880. Wheeling, WV: W.J. Johnson Public Printers, 1881.

Board of Control. Sixteenth Report of the West Virginia Board of Control 1948-1951. Compiled by Robert G. Hanlen in conjunction with the superintendents of the institutions and under supervision of the Board of Control. 1951. West Virginia Collection, West Virginia University Library.

Camden, Thomas Bland, M.D. My Recollections and Experiences of the Civil War or A Citizen of Weston During the Late Unpleasantness. Parsons, WV: Friends of the Louis Bennett Public Library/ McClain Printing Company, 2000.

Charleston Gazette. January 23,24,25,26,27, 1949; August 30, 1980; October 22,1980 .

Clarksburg Exponent. October 4, 1935; October 27, 1935.

Fourth Biennial Report of the State Board of Control of West Virginia for the Period July 1, 1914, to June 30, 1916. Charleston, WV: Tribune Printing Company, 1916.

Garrison, Harry, Superintendent, Weston State Hospital. Letter to Joseph Terrell, President of West Virginia Board of Control, 9 September 1943. West Virginia Collection, West Virginia University Library. Board of Control papers. Microfilm A\&M 1976. 
Kirkbride, Thomas. On the Construction, Organization and General Arrangements of Hospitals for the Insane. Philadelphia: J.B. Lippincott, 1880; reprint, New York: Arno Press, 1973.

Marsh, William A., ed. 1880 Census of West Virginia, Vol. 1: Lewis, Upshur, Taylor, Barbour. Parsons, WV: McClain Printing Company, 1979.

Pittsburgh Post Gazette. June 20, 1999.

Report of the Directors, Superintendent and Treasurer of the West Virginia Hospital for the Insane for the Years 1889 and 1890. Charleston, WV: Moses W. Donnelly Public Printer, 1890.

Reporter's Transcript in the Case of Hearing Before the State Board of Control. Fairmont, WV:August 1927. West Virginia Collection, West Virginia University Library. Board of Control papers. Microfilm A\&M 1976.

Sixth Annual Report of the Directors and Superintendent of the West Virginia Hospital for the Insane, 1869. Wheeling, WV: John Frew, Printer, 1870.

Trans-Allegheny Lunatic Asylum Time Book for 1865-1866. West Virginia Collection, West Virginia University Library. Microfilm: A\&M 2193.

Weston Democrat. November 6 and 13, 1871; October 4 and 11, 1935, October 7 , 1992, April 12, 2006, March 20, 2008.

The Westoneer [Weston State Hospital patient/staff newsletter], May 1953, September 1953, December 1953, March 1955, August 1955, November 1955, December 1955, September 1956.

West Virginia Department of Mental Health, 19th Annual Report, 1976-1977.

West Virginia Department of Mental Health, Annual Report, 1966-1967. Charles ton, West Virginia. M. Mitchell-Bateman, M. D., Director. 
Interviews:

Anonymous housekeeper, Weston State Hospital. Interview by author, January $10,2008$.

Haller, Mildred, business department, Weston State Hospital. Interview by author, February 8, 2008.

Haller, Thom, student recreation department employee, Weston State Hospital. Interview by author, December 20, 2007.

Lowther, Ruth, health service worker, Weston State Hospital. Interview by author, November 9, 2007.

Mason, Shirley, registered nurse, Weston State Hospital. Interview by author, December 13, 2007.

Security guard and switchboard operator, Weston State Hospital. Interview by author, January 8, 2008.

Staubly, Karl, Alcohol and Substance Abuse case manager and counselor, Weston State Hospital. Interview by author, November 10, 2007.

Todt, Dr. Michael A., Director of Clinical Support Services and Administrator, Weston State Hospital. Interview by author, November 1, 2007.

White, Jean, citizen of Weston. Interview by author, February 8, 2008.

White, Ross, citizen of Weston. Interview by author, February 16, 2006.

Secondary sources:

Alder, Bill. Yesteryears. Weston, WV: Hackers Creek Pioneer Descendants, 1983.

Berger, Lisa and Alexander Vuckovic. Under Observation: Life Inside the McLean Psychiatric Hospital. New York: Penguin Books, 1995. 
Carr, Marjorie. Weston Hospital, 1858-1992. Weston, WV: privately printed, 1992.

Chapman, Lawrence. History of Weston Hospital, Vol. 1, 2, 3. Weston, WV: by the author, 1988.

. Weston Hospital in Transition, Weston, WV: by the author, [1989].

Charleston Gazette. January 2, 2005.

Dowdall, George. The Eclipse of the State Mental Hospital: Policy, Stigma, and Organi zation. Albany, NY: State University of New York Press, 1996.

Deutsch, Albert. The Shame of the States. New York: Harcourt, Brace and Company, 1948.

Frontline: The New Asylums. Boston: Public Broadcasting Service WGBH Educa tional Foundation: c1995-2005 [Internet]; available from http://www.pbs.org/wgbh/pages/frontline/shows/asylums/etc/ faqs.html.

Gerrard, Louise Burr. Impact of a Federal Grant-in-aid Program on an Economically Depressed, Rural State: A Case Study of Mental Health Programs in West V ir ginia. Ann Arbor: University Microfilms International, 1969.

. Mental Health Services: Statehood to 1957. The Department of Mental Health 1957-1968. Charleston, West Virginia: Department of Mental Health, 1970.

. "The Department of Mental Health," excerpted from "Impact of a Federal Grant-in-Aid Program on an Economically Depressed, Rural State: A Case Study ofMental Health Programs in West Virginia," Ph.D. diss., Department of Public Law and Government, Columbia University, 1969.

Gilchrist, Joy Gregoire and Charles H. Gilchrist. Lewis County, West Virginia: A Pictorial History of Old Lewis County, The Crossroads of Central West Virginia. Virginia Beach, VA: The Donning Company, 1993. 
Gilchrist-Stalnaker, Joy. A Short History of Weston Hospital (Trans-Allegheny Asylum for the Insane, Weston State Hospital). Horner, WV: Hacker's Creek Pioneer Descendants, 2001.

Goodman, Barak, and John Maggio, The American Experience: The Lobotomist program transcript, Boston: Public Broadcasting Service, WGBH, 2007 [internet]; available from http://www.pbs.org/wgbh/amex/lobotomist/ program/pt.html,.

Lael, Richard L., Barbara Brazos, and Margot Ford McMillen. Evolution of a Missouri Asylum: Fulton State Hospital, 1851-2006. Columbia, Missouri: University of Missouri Press, 2007.

Lightner, David L., ed. Asylum, Prison, and Poorhouse: The Writings and Reform Work of Dorothea Dix in Illinois. Carbondale: Southern Illinois University Press, 1999.

McCusker, John J. "Comparing the Purchasing Power of Money in the United States (or Colonies) from 1665 to 2005.” Economic History Services, c2006 [Internet]. Available from URL: http://www.eh.net/hmit/ppowerusd/.

Morgantown Dominion Post, August 20, 1986.

Navasky, Miri and Karen O'Connor. Frontline: The New Asylums. Boston: Public Broadcasting Service WGBH Educational Foundation, c2005 [Internet]. Available from http://www.pbs.org/wgbh/pages/frontline/shows/ asylums/. .2005. Frontline: The New Asylums. 60 min. WGBH Educational Foundation: distributed by PBS Video. Videorecording.

National Alliance on Mental Illness, "Grading the States 2006: West Virginia Narrative," [nternet]; available from http://www.nami.org/ gtstemplate.cfm?section=grading the states\&template $=/$ ContentManagement/ContentDisplay.cfm\&ContentID=30906. 
Rothman, David J. The Discovery of the Asylum: Social Order and Disorder in the New Republic. Glenview, Illinois: Scott, Foresman and Company, 1971.

Sage, DeWitt. Frontline: A Place for Madness. 57 min. WGBH Educational Founda tion PBS Video, 1994. Videorecording.

Salisbury, Richard F. Structures of Custodial Care: An Anthropological Study of a State Mental Hospital. Berkeley: University of California Press, 1962.

Smith, Edward Conrad. A History of Lewis County, West Virginia. Weston, W. Va.: the author, Morgantown Printing and Binding, 1920.

Smith, Vicki. "Asylum's renaming insults advocates," Associated Press, Yahoo News. [Internet]; available from http://news.yahoo.com/s/ap/20080321/ ap on re us/lunatic asylum,

Torrey, E. Fuller. Out of the Shadows: Confronting America's Mental Illness Crisis. New York: John Wiley and Sons, 1997.

Weston Gold Robbery Committee: The Great Weston, West Virginia, Gold Robbery: West Virginia's First Treasury, c2001-2006 [Internet]; available from http:// westongoldrobbery.com/great gold robbery.htm.

Weston Hospital Revitalization Committee, Weston, WV: c2005 [Internet]; available from http://www.westonlandmark.com/index.htm..

Whitaker, Robert. Mad in America: Bad Science, Bad Medicine, and the Enduring Mistreatment of the Mentally Ill. Cambridge, MA: Perseus Publishing, 2002.

Zwelling, Shomer S. Quest for a Cure: The Public Hospital in Williamsburg, Virginia, 1773-1885. Williamsburg, Virginia: The Colonial Williamsburg Founda tion, 1985. 